
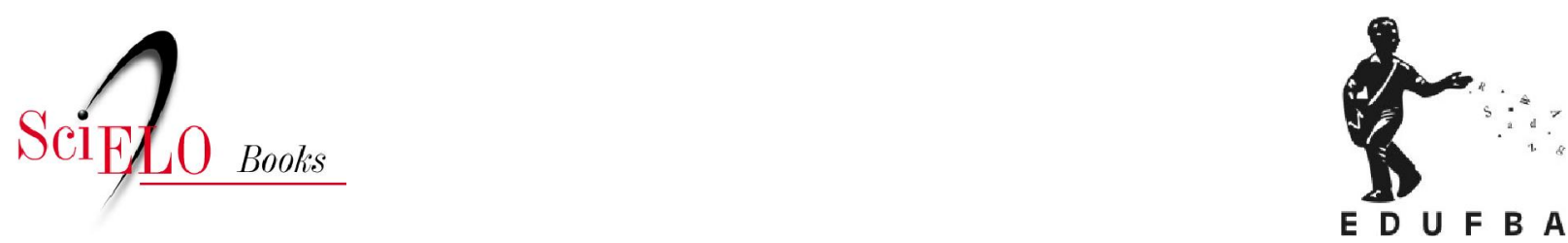

\title{
Memória e formação de professores
}

\author{
Antônio Dias Nascimento \\ Tânia Maria Hetkowski \\ (orgs.)
}

NASCIMENTO, AD., and HETKOWSKI, TM., orgs. Memória e formação de professores [online]. Salvador: EDUFBA, 2007. 310 p. ISBN 978-85-232-0918-6. Available from SciELO Books $<\underline{\text { http://books.scielo.org }>\text {. }}$

\section{(1) $(0)$}

All the contents of this work, except where otherwise noted, is licensed under a Creative Commons Attribution-Non Commercial-ShareAlike 3.0 Unported.

Todo o conteúdo deste trabalho, exceto quando houver ressalva, é publicado sob a licença Creative Commons Atribuição Uso Não Comercial - Partilha nos Mesmos Termos 3.0 Não adaptada.

Todo el contenido de esta obra, excepto donde se indique lo contrario, está bajo licencia de la licencia Creative Commons Reconocimento-NoComercial-CompartirIgual 3.0 Unported. 
MEMÓRIA E FORMAÇÃO DE PROFESSORES 


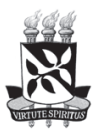

Universidade Federal da Bahia

REITOR

Naomar Monteiro de Almeida Filho

VICE-ReITOR

Francisco Mesquita

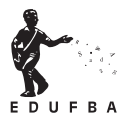

Editora da Universidade Federal da Bahia

DiRETORA

Flávia Goullart Mota Garcia Rosa

CONSElHo EdITORIAL

Titulares

Angelo Szaniecki Perret Serpa

Caiuby Álves da Costa

Charbel Niño El Hani

Dante Eustachio Lucchesi Ramacciotti José Teixeira Cavalcante Filho

Maria do Carmo Soares Freitas

Suplentes

Alberto Brum Novaes

Antônio Fernando Guerreiro de Freitas

Armindo Jorge de Carvalho Bião

Evelina de Carvalho Sá Hoisel

Cleise Furtado Mendes

Maria Vidal de Negreiros Camargo

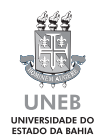

UNIVERSIDADE D O ESTADO DA BAHIA

ReITOR

Lourisvaldo Valentim da Silva

Diretora do Departamento de Educação

(DEDC) CAmpus I

Ângela Maria Camargo Rodrigues

Coordenadora do Programa de

Pós-Graduação Educação e

Contemporaneidade (PPGEduC)

Nádia Hage Filho

Vice- Coordenador do Programa de

Pós-Graduação Educação e

Contemporaneidade (PPGEduC)

Arnaud Soares de Lima Junior

Coordenadores das Linhas de Pesquisa

do Programa de Pós-Graduação em

Educação e Contemporaneidade (PPGEduC)

Kátia Maria Santos Mota

Maria de Lourdes Soares Ornellas Farias

Ivan Luiz Novaes

Revisora de Texto (PPGEduC)

Maria Nilza de Oliveira Fernandes

Conselho EDITORIAL

Cezar Nonato Bezerra Candeias (UFAL)

Edileise Mendes (UFBA)

Elizeu Clementino de Souza (UNEB)

Leda Scheide (UFSC)

Lucila Pesce (PUC/SP)

Marcos Botelho (UEFS)

Zenilde Durli (UNOESC) 
MEMÓRIA E FORMAÇÃO DE PROFESSORES

ORGANIZADORES

Antônio Dias Nascimento

Tânia Maria Hetkowski

Salvador

Edufba, 2007 
Direitos para esta edição cedidos à Edufba. Feito o depósito legal.

Nenhuma parte deste livro pode ser reproduzida, sejam quais forem os meios empregados, a não ser com a permissão escrita do autor e das editoras, conforme a Lei ${ }^{\circ}$ 9.610, de 19 de fevereiro de 1998.

\author{
CAPA \\ Gabriela Nascimento \\ Projeto GRÁfico \\ Gabriela Nascimento \\ REVISÃO \\ Susane Barros \\ Flávia Rosa
}

Biblioteca Central Reitor Macêdo Costa - UFBA

Memória e formação de professores / organizadores : Antônio Dias

Nascimento, Tânia Maria Hetkowski. - Salvador : EDUFBA, 2007.

310 p.

Coletânea realizada em parceria entre os pesquisadores da Universidade do Estado da Bahia, Universidade Estadual do Rio de Janeiro, Universidade Federal de Santa Catarina, Universidade Federal da Bahia e Universidade do Oeste de Santa Catarina.

ISBN 978-85-232-0484-6

1. Educação - Brasil - História. 2. Professores - Formação.

3. Educação - Aspectos sociais. I. Nascimento, Antônio Dias.

II. Hetkowski, Tânia Maria. III. Universidade do Estado da Bahia.

IV. Universidade Federal da Bahia.

CDD - 370.981

Editora da UFBA

Rua Barão de Jeremoabo, $\mathrm{s} / \mathrm{n}$ - Campus de Ondina 40170-290 - Salvador - BA

Tel: +55 $713283-6164$

Fax: +55 $713283-6160$

www.edufba.ufba.br

edufba@ufba.br 


\section{Agradecimentos}

Os textos apresentados neste livro são resultantes de pesquisas realizadas tanto no âmbito do Programa de Pós-Graduação em Educação e Contemporaneidade, do Departamento de Educação do Campus I, da Universidade do Estado da Bahia, como em outros Programas de PósGraduação em Educação de outras universidades do Brasil.

A publicação desses trabalhos para torná-los acessíveis a um público mais amplo, no entanto, é um esforço de um conjunto de pessoas e instituições aos quais os organizadores desta obra gostariam de externar o seu profundo reconhecimento pelo apoio e encorajamento recebidos.

A primeira menção é devida aos autores que além da dedicação à investigação acadêmica, já por si meritória, aceitaram de bom grado o nosso convite para somarem-se conosco para a realização dessa jornada em prol do conhecimento, partilhando os nossos achados, tanto com o público acadêmico, como com o público em geral.

À Professora e Mestra Ângela Maria Camargo Rodrigues, que na sua missão de Diretora do Departamento de Educação (DEDC) Campus I da UNEB, compreendendo e valorizando este nosso intento, não mediu esforços na sua atuação com os interlocutores da Petrobras para a obtenção do indispensável apoio cultural.

À Professora Doutora Nádia Hage Fialho, Coordenadora do nosso Programa de Pós-Graduação em Educação e Contemporaneidade, pelo estímulo e pela confiança em nós depositada para produção e organização deste trabalho.

Ao Professor Dr. Cezar Nonato Bezerra Candeias, da Universidade Federal de Alagoas, pela gentileza da leitura e cuidadosa apreciação crítica de todos os textos assegurando ainda mais a pretendida qualidade e clareza das exposições.

À nossa colega Maria Nilza de Oliveira Fernandes, do PPGEduC, pelo seu empenho nas primeiras revisões dos textos, antes de submetê-los ao processo de editoração. 
A Flávia Goulart Garcia Rosa e Gabriela Nascimento, pelo trabalho minucioso de edição dos textos, no âmbito da Editora da Universidade Federal da Bahia, e pela encorajadora acolhida à nossa proposta editorial. À Companhia de Petróleo do Brasil S. A., pela inclusão do nosso livro entre os inúmeros beneficiários do apoio cultural prestado por ela a diferentes instituições voltadas para o desenvolvimento científico, cultural e artístico. 


\section{Sumário}

9 | ApresentaçÃo

17 | O PÓS-ABOLIÇÃO NA BAHIA: MEMÓRIA À CONSTRUÇÃO DA VIDA LIVRE Jaci Maria Ferraz de Menezes, Juvino Alves dos Santos Filho

43 I SAga nordestina: identidade(s) CULtural(is) E EXCLUSÃO SOCIAL Yara Dulce Bandeira de Ataíde

59 | (AUTO)BIografia, HiSTÓRIAS DE VIDA E PRÁTICAS DE FORMAÇÃO

Elizeu Clementino de Souza

75 | CONTRIBUIÇÃO HISTORIOGRÁFICA AO DEBATE SOBRE AÇÕES AFIRMATIVAS: EXCLUSÃO RACIAL NA BAHIA DO SÉCULO XIX Wilson Roberto de Mattos

87 | BRANQUEAMENTO E BRANQUITUDE: CONCEITOS BÁSICOS NA FORMAÇÃO PARA A ALTERIDADE Ana Célia da Silva

103 | MOVIMENTOS SOCIAIS RURAIS, QUARENTA ANOS DEPOIS Antônio Dias Nascimento

119 | O PROJETO PEDAGÓGICO DO MST: A EXPERIÊNCIA EM ESCOLAS DE VITÓRIA DA CONQUISTA Rosana Mara Chaves Rodrigues

133 Aspectos CONSTITUTIVOS PARA UMA ANÁLISE DA ESCOLA EXCLUSIVA Luciene Maria da Silva 
151 A REPRESENTAÇÃO SOCIAL DA TRANSFERÊNCIA DO PROFESSOR E DO ALUNO NA SALA DE AULA Maria de Lourdes S. Ornellas

163 | CONSCIENTIZAÇÃO: UMA DAS ESTRATÉGIAS NA FORMAÇÃO CONTINUADA Vânia Finholdt Ângelo Leite

179 | CIDADANIA NA FORMAÇÃO DO PROFESSOR: DESVELANDO SENTIDOS E FINALIDADES DA PRÁTICA EDUCATIVA Sandra Regina Soares

199 | O MOVIMENTO NACIONAL PELA REFORMULAÇÃO DOS CURSOS DE FORMAÇÃO DO EDUCADOR: EMBATES NA CONSTRUÇÃO DE UM PROJETO COLETIVO DE FORMAÇÃO

Zenilde Durli

219 | UNIVERSIDADE E FORMAÇÃO DE PROFESSORES: QUAL O PESO DA FORMAÇÃO INICIAL SOBRE A CONSTRUÇÃO DA IDENTIDADE PROFISSIONAL DOCENTE?

Cristina Maria D'ávila

241 | Políticas públicas E EDUCAÇão DE JOVENS E ADULTOS Maria Olívia de Matos Oliveira

257 A FORMAÇÃO DOS PROFESSORES NO BRASIL E EM SANTA CATARINA: DO NORMALISTA AO DIPLOMADO NA EDUCAÇÃO SUPERIOR Leda Scheiba e lone Ribeiro Valle

273 SABERES DOCENTES NA FORMAÇÃO CONTINUADA DE PROFESSORES DAS SÉRIES INICIAIS DO ENSINO FUNDAMENTAL: UM ESTUDO COM GRANDEZAS E MEDIDAS

Suzeli Mauro

291 | EDUCAÇÃO MUSICAL: UM ESTUDO A PARTIR DE EXPERIÊNCIAS PEDAGÓGICAS NA ESCOLA DE MÚSICA DA UNIVERSIDADE FEDERAL DA BAHIA Leila Miralva Martins Dias

305 | SOBRE OS AUTORES 


\section{Apresentação}

Os estudos aqui reunidos têm como destaque as temáticas Memória e Formação de Professores. Ampliando os esforços no sentido de aproximar, por um lado, a idéia de Contemporaneidade, entendida como o esforço comum em busca da construção de relações sociais harmoniosas, baseadas nos idéias de solidariedade, respeito às identidades, convivência com a diversidade e, sobretudo, de respeito e preservação da vida, e, por outro, a idéia de Educação vista como um processo de formação de sujeitos autônomos, solidários e participativos.

A primeira temática diz respeito à Memória da Educação, um dos eixos de interesse de investigação do nosso Programa de Pós-Graduação em Educação e Contemporaneidade (PPGEduC), considerando a importância de se identificar o modo como se entrecruzaram aqui os vários processos civilizatórios e como se articularam com os processos educativos no que se refere a história da educação, pluralidade cultural, movimentos sociais, representação social e inclusão.

A segunda temática contempla, mais especificamente, a Formação de Professores. Em verdade, de pouco adianta adotar-se uma visão de futuro baseada na busca de novas utopias, se não tomarmos também como prioridade os estudos e pesquisas que contribuam para a formação de novos agentes destinados ao papel de formadores para um mundo mais humano e justo. Por acreditarmos que este esforço de investigação e de práticas sociais, participativo e dialógico, é que buscamos a parceria de outros pesquisadores que, como nós, mesmo estando em outros recantos do País, convergem para as mesmas preocupações.

Assim é que a presente coletânea é resultado de uma parceria realizada entre os pesquisadores do PPGEduC da Universidade do Estado da Bahia (UNEB) e pesquisadores de mais quatro universidades brasileiras, tais como Universidade Estadual do Janeiro (UERJ), Universidade Federal de Santa Catarina (UFSC), Universidade Federal da Bahia (UFBA) e Universidade do Oeste de Santa Catarina (UNOESC). Somos profundamente agradecidos 
a todos eles por estarmos juntos partilhando os resultados de nossas investigações no campo da educação.

O primeiro capítulo, intitulado Pós-abolição na Babia: memória à construção da vida livre tem a co-autoria de Jaci Maria Ferraz de Menezes e Juvino Alves dos Santos Filho. Discute as relações da população negra na Bahia com a educação formal e as formas e processos educativos que utilizaram e organizaram para aprender, na medida da sua exclusão do sistema educacional formal. Pretende demonstrar que, apesar de todas as dificuldades para até a sobrevivência física, os negros desenvolveram sua história e formas próprias de inclusão e de aprendizagem, através, inclusive, da organização de escolas ou através de outras instituições pedagógicas.

Em seguida, o estudo nomeado Saga nordestina: identidade(s) cultural (is) e exclusão social de autoria de Yara Dulce Athayde aborda a questão da(s) identidade(s) cultural(ais) nordestina(s) a partir da proposta teórica apresentada por Michel Zaidan Filho sobre a construção da concepção de Nordeste. Apresentamos duas histórias de vida de mulheres nordestinas que serão utilizadas como referências e nos permitirão transitar entre algumas questões atuais como identidade(s) e exclusão social. Concluímos com a relação entre as histórias de vida e as explicações teóricas.

O terceiro capítulo (Auto)Biografia, histórias de vida e práticas de formação de autoria de Elizeu Clementino de Souza estabelece a discussão sobre as aproximações e possíveis distanciamentos entre as (auto)biografias, a história da educação e as práticas de formação, por entender que "as escritas das obras autobiográficas que testemunham as relações pessoais com a escola podem ser úteis como fonte para a elaboração da história da educação" (CATANI, 2005, p. 32), ao traduzir sentimentos, representações e significados individuais das memórias, histórias e relações sociais com a escola.

O texto Exclusão racial na Babia do século XIX: contribuição historiográfica ao debate sobre ações afirmativas, de autoria de Wilson Roberto de Mattos, faz uma abordagem sobre as ações afirmativas, destacando, na história do Brasil, processos concretos que reforçam argumentos relativos à necessidade e justiça na adoção de tais medidas, bem como este texto, contextualiza as ações afirmativas como medidas construtoras da igualdade racial e, sobretudo, como medidas de reparação 
de discriminações e exclusões das populações negras, têm sua necessidade confirmada pela História.

O capítulo Branqueamento e branquitude: conceitos básicos na formação para a alteridade, de autoria de Ana Célia da Silva, apresenta um relato de pesquisa que investiga, através de análise de conteúdo, como o livro didático de Língua Portuguesa de Ensino Fundamental de $1^{\circ}$ e $2^{\circ}$ ciclos representa os personagens brancos e como essa representação pode contribuir para a construção de um sentimento de superioridade desse grupo étnico-racial. O desejo de aproximar-se cultural e fenotipicamente desse grupo por outros grupos étnico-raciais e os mecanismos construídos pelo branco e assemelhados, para permanecer enquanto modelo de humanidade e cidadania, tem-se constituído em ideologias hegemônicas de branqueamento e branquitude, respectivamente. A investigação estabelece suas bases teóricas em autores como Hasenbalg, Munanga, Silva, Carone, Piza e Bento.

Também em torno da Memória da Educação, inclui-se o capítulo intitulado Movimentos sociais rurais, quarenta anos depois, de autoria de Antônio Dias Nascimento, analisando as condições sócio-históricas nas quais emerge a educação popular no Nordeste do Brasil, como produto da necessidade de integrar os trabalhadores rurais ao processo de desenvolvimento encetado entre meados dos anos de 1950 até os primeiros anos da década de 1960. O autor conclui que o processo de educação popular que se estabeleceu, sobretudo a partir da influência de Paulo Freire, resultou no surgimento de uma nova consciência entre os trabalhadores rurais, tendo como evidência maior a sua organização social e política.

A temática sobre memória vem apresentar o artigo O Projeto pedagógico do MST: a experiência em escolas de Vitória da Conquista, de autoria de Rosana Mara Chaves Rodrigues, o qual tem como objetivo identificar os elementos importantes de resistência e de mudança que emergem do confronto entre uma proposta educativa que se pretende transformadora, libertadora e inclusiva, e a realidade local, estruturada segundo os padrões sociais e culturais que tendem a reproduzir a condição de dependência e de submissão e exclusão. Conclui-se que as escolas sobre a coordenação do Movimento dos Sem Terra (MST) têm se diferenciado das demais escolas do município por estabelecer canais de negociação com o poder local; por partir das práticas concretas da escolarização e das demandas das lutas 
pela terra na formulação dos seus conteúdos e metodologia de trabalho; por garantir o acesso e permanência de todas as crianças nas séries iniciais do ensino fundamental, entre outros.

A questão da inclusão social no campo da educação é aqui abordada através do capítulo intitulado Aspectos constitutivos para uma análise da escola inclusiva, de autoria de Luciene Maria da Silva, que discute a proposta inclusivista, entendendo-a como uma abordagem crítica à educação especial, mas não só a ela, posto que pretende ser uma orientação que atenda às necessidades de todos os alunos. A autora considera que a discussão sobre inclusão e exclusão torna-se simplista se não considera a sociedade na sua totalidade e, sobretudo, se não considera como se manifestam os fatos que evidenciam tais fenômenos. A partir dessa perspectiva, o texto apresenta reflexões sobre a Educação Especial e seus processos de disciplinamento postos pelas práticas assistencialistas e filantrópicas e, posteriormente, analisa os fundamentos da Educação Inclusiva e as dificuldades práticas que se tem posto para dar acesso aos alunos com deficiência à escola regular.

Em seguida, trazendo contribuições da psicanálise para o campo da educação, o capítulo intitulado A representação social da transferência do professor e do aluno na sala de aula, de autoria de Maria de Lourdes Ornellas revela que os construtos educação, representação social e afetividade, se bem trabalhados, possibilitam o enlace com vistas a escutar o que se passa no cotidiano da escola, na transferência entre professor aluno e no processo ensino/aprendizagem. Expressa o conceito de representação social no campo do conhecimento do senso comum, isto é, constituída pelas relações que o sujeito articula no seu cotidiano. Tenta fazer uma interface dessa teoria com a psicanálise pela via da comunicação e da cultura, traz o conceito de afeto enquanto uma dimensão fundante e se constitui na interface do prazer e do desprazer, o que ajuda a escutar o bem-me-quer e o mal-me-quer vividos na educação e, de forma singular, na escola.

O capítulo Conscientização: uma das estratégias na formação continuada, de autoria de Vânia Finholdt Ângelo Leite, recolhendo os seus referenciais em Alarcão, Scarpa, Tardif, Nóvoa e Freire, desenvolve um estudo ligado à formação continuada de professores. A autora busca analisar a influência das estratégias propostas na formação baseada na reflexão, resolução de problemas e na conscientização das práticas pedagógicas ligadas a números e operações e as conseqüentes mudanças de atuação dos professores. Assim, 
tratou-se de buscar os elementos de uma formação continuada que propiciassem a transposição de conhecimentos e pesquisas nas diversas áreas para a prática cotidiana.

O texto Cidadania na formação do professor: desvelando sentidos $e$ finalidades da prática educativa, de autoria de Sandra Regina Soares, parte da constatação da existência, na sociedade brasileira, de uma tendência à aceitação resignada, em outros termos, da falta de consciência de cidadania, e apresenta o desafio com respeito à formação de professores de contribuir para o enfrentamento dessa tendência, mediante, principalmente, o compromisso político-pedagógico dos seus profissionais de trabalhar em favor do desenvolvimento integral do ser humano e de sua autonomia. Essa discussão sobre o conceito moderno de cidadania, inclui as principais visões existentes na literatura brasileira, denominadas neste estudo: cidadania de direitos restritos e cidadania como construção social. A reflexão sobre a formação da consciência de cidadania, no contexto da prática educativa na universidade, desenvolve-se mediante a discussão sobre o conceito de relação com o saber, que se desdobra na relação do estudante consigo mesmo, com os outros, com as regras e com o poder.

O capítulo O movimento nacional pela reformulação dos cursos de formação do educador: embates na construção de um projeto coletivo de formação, de autoria de Zenilde Durli, busca analisar e compreender as proposições construídas no âmbito do Movimento Nacional pela Reformulação dos Cursos de Formação do Educador, iniciado no contexto de redemocratização vivenciado pela sociedade brasileira, a partir do final da década de 1970. Nas proposições desse Movimento buscamos evidências das divergências teóricas e dos consensos alcançados bem como a repercussão destes no processo de elaboração das Diretrizes Curriculares Nacionais para o Curso de Graduação em Pedagogia.

O capítulo intitulado Universidade e formação de professores: qual o peso da formação inicial sobre a construção da identidade profissional docente?, de autoria de Cristina d'Ávila Maheu, apresenta preliminarmente, relato de pesquisa exploratória que tem como objetivo analisar, para melhor compreender o processo de construção da identidade profissional, junto a estudantes de um curso de formação inicial de professores (licenciatura), numa universidade pública na Bahia. O estudo combina duas etapas de pesquisa, uma primeira de natureza quantitativa (sondagem por 
questionário) e uma segunda, qualitativa, de análise das representações sociais presentes nas narrativas autobiográficas dos estudantes, sujeitos do estudo. Segundo os resultados provisórios da pesquisa, concebemos como principais hipóteses: a) o curso de formação inicial possui um peso relativo sobre a construção da identidade profissional docente; b) as disciplinas do curso de licenciatura não parecem corresponder às representações de docência dos estudantes.

O texto Políticas públicas e educação de jovens e adultos, de autoria de Maria Olívia de Matos Oliveira, apoiado em pesquisa realizada junto à Universidade Antônoma de Barcelona, desenvolve uma análise crítica das políticas públicas de educação de jovens e adultos, implantadas pelo governo do Estado da Bahia, no período de 2002-2006, materializadas no Programa Oficial Educar Para Vencer. Foi nossa intenção durante a investigação, quebrar paradigmas tradicionais de avaliação de programas, buscando conceber a avaliação como processo e não como produto, dar visibilidade ao cotidiano dos sujeitos, tentando entender suas resistências e medos, revelados através de suas falas. Os resultados indicaram que o programa Educar Para Vencer está longe de satisfazer as exigências propostas, pois não atende às necessidades das cidades onde está implantado e não tem uma estrutura de recursos humanos e materiais que dê suporte e responda satisfatoriamente às necessidades dos alunos, condição imprescindível para legitimar a sua eficácia.

O estudo intitulado A formação dos professores no Brasil e em Santa Catarina: do normalista ao diplomado na educação superior, da co-autoria de Leda Scheibe e Ione Ribeiro Valle. As autoras levantam a hipótese de que a profissionalização e a formação dos professores sempre estiveram no centro dos projetos e investimentos do Estado brasileiro, visando ao mesmo tempo organizar as massas, ampliar o controle sobre a escolarização da população e ampliar as oportunidades de acesso aos sistemas públicos de ensino. Destacase, como referência, a análise dos principais dispositivos legais que estabelecem as políticas de educação para o país, bem como as diferentes etapas da formação docente, partindo-se do pressuposto que elas correspondem às mutações das prioridades e diretrizes do Estado brasileiro em termos de educação escolar, introduzidas ao longo do século XX.

O texto Saberes docentes na formação continuada de professores das séries iniciais do ensino fundamental: um estudo com grandezas e medidas, 
de autoria de Suzeli Mauro, apresenta a trajetória da pesquisa realizada com um grupo de estudos composto por duas formadoras, que trabalham com a disciplina Didática da Matemática no nível superior e dez professoras que atuam nos níveis iniciais da Educação Básica, em instituições particulares de ensino. Relata a autora que a investigação, um estudo de caso, originou-se das inquietações de uma das professoras do grupo com relação ao ensino de área e perímetro, que desencadeou na elaboração e execução de uma seqüência de atividades para a $4^{a}$ série do $2^{\circ}$ ciclo do ensino fundamental, com um grupo de vinte e seis alunos. Assim, a seqüência intitulada Medindo, comparando e produzindo teve origem e foi realimentada no grupo de estudos, que contava com encontros semanais, para a discussão de propostas nas diversas etapas: elaboração, desenvolvimento, fechamento e avaliação do trabalho.

Fechando o elenco dos estudos que compõem essa obra, e retomando o caminho para o diálogo entre a música e outras disciplinas do sistema oficial de ensino, o capítulo intitulado Educação musical: um estudo a partir de experiências pedagógicas na Escola de Música da Universidade Federal da Babia, de autoria de Leila Miralva Martins Dias, apresenta um breve panorama da situação da educação musical no Brasil e, em seguida, discute, a partir do conhecimento produzido pelas pesquisas na área da educação musical, a idéia de educação musical como sendo processo que visa tanto o desenvolvimento artístico e cultural, como a formação integral dos educandos como sujeitos. O estudo se baseia nas experiências pedagógicas desenvolvidas no Projeto Coral da Escola de Música da Universidade Federal da Bahia.

Cumpre-nos destacar que essa obra tornou-se possível graças ao decisivo apoio da Petrobras, que ampliando o seu papel no desenvolvimento nacional, vê, como parte dessa tarefa, o apoio ao desenvolvimento científico e cultural.

\author{
Dr. Antônio Dias Nascimento \\ Dra. Tânia Maria Hetkowski
}





\section{O pós-abolição na Bahia: memória à construção da vida livre}

Jaci Maria Ferraz de Menezes

Juvino Alves dos Santos Filho

Este texto tem como finalidade apresentar e discutir as relações da população negra na Bahia com a educação formal e as formas e processos educativos que utilizaram e organizaram para aprender, na medida da sua exclusão do sistema educacional formal. Pretende demonstrar que, apesar de todas as dificuldades até mesmo a sobrevivência física, os negros desenvolveram formas próprias de inclusão e de aprendizagem, através inclusive de organização de escolas ou através de outras instituições pedagógicas.

Os estudos que realizamos (MENEZES, 1994; MENEZES, 1997a), sobre a exclusão dos negros da escolarização mostraram que, no Brasil e na Bahia, os não brancos foram adquirindo o direito à escola muito lentamente, no pós-abolição. Formalmente excluídos os escravos, os libertos tinham acesso à escola na medida de suas possibilidades - inexistiu, durante a escravidão ou depois dela, uma política de massas voltada explicitamente para garantir aos ex-escravos o acesso à escola. As discussões travadas no período final do Império, também período em que recrudescem os debates sobre o final da escravidão e a melhor forma de preparar a inclusão dos ex-escravos à cidadania brasileira, desembocam na apresentação, limitada, de projeto de organização de um sistema de ensino que promovesse o acesso das crianças livres à escolarização. 
Este debate é retomado no início da República. Um sistema de educação é organizado segundo a definição que cada Estado membro federado dá ao direito à educação e sua capacidade de manutenção das mesmas escolas, incorporando, lentamente, gerações futuras - não os escravos recém libertados, adultos, - à cidadania. Contraditoriamente, o acesso ao voto era condicionado, para os adultos, ao saber ler e escrever, entendendo-se a alfabetização como condição necessária para a aquisição de uma “capacidade de discernimento". Numa sociedade constituída majoritariamente de negros e analfabetos, isto significava a exclusão da maioria da cidadania ativa; de tal modo que a abolição garante, aos exescravos, a liberdade, mas não a igualdade (MENEZES, 1997b). Daí a luta pelo acesso à escola e as iniciativas, entre os segmentos excluídos, de criar classes escolares em suas organizações, como veremos adiante, ainda no aspecto do desenvolvimento das artes e da musicalidade como fruto do aprendizado não formal e depois mesmo formal. Destacamos aqui a luta também de vanguarda de abolicionistas, engajados no processo de ampliação dos direitos à cidadania.

\section{A EDUCAÇÃO DOS ESCRAVOS, LIBERTOS, INGÊNUOS}

Neste estudo do processo de inclusão/exclusão, queremos começar discutindo o próprio limite da exclusão. No nosso entendimento, os negros, no Brasil, passam por um processo de "inclusão excludente". Trazidos para o Brasil, sua socialização/educação se dá no espaço do colonizador, mas como desigual, como subordinado; o indígena, também subordinado, tinha um espaço próprio de vida e socialização/educação, os aldeamentos e as missões. O aldeamento tinha como suposto a "civilização" do indígena e previa, ao lado da catequese, a instalação de escolas de ler e escrever. $\mathrm{O}$ negro estava na fazenda ou na cidade; sua aprendizagem, enquanto escravo, se dava no aprendizado do trabalho na execução do trabalho; mesmo a sua catequese, de forma simplificada, se dava nas fazendas, nas igrejas, nas irmandades. Mesmo durante a escravidão, a exclusão da escolarização se fazia tendo como critério a condição civil - a condição de escravo ou livre. Não era vedado formalmente o acesso à escola dos negros livres, embora 
não existisse, para eles como para o conjunto da população, um direito à educação, apenas estabelecido na década de 1930 do século $\mathrm{XX}^{1}$.

Os escravos eram formalmente excluídos da escolarização durante a Colônia e o Império. Algo como se o Estado não devesse valorizar a propriedade privada, porque mesmo se o próprio senhor quisesse matriculálo nas escolas públicas não o podia fazer. Esta segue a prática até o momento da Abolição (BAHIA, 1989). Se aos escravos era vedado o acesso a instituições públicas de ensino, aos negros nascidos livres se lhes providenciava, quando fora da tutela do senhor da sua mãe, educação em espaços compulsórios de formação para o trabalho, fossem orfanatos, fossem Companhias de Aprendizes do Exército ou Armada.

Aos libertos ou livres descendentes de escravos que tivessem como prover sua subsistência, era possível a matrícula na escola pública. Falam sobre a existência de professores negros, dentre outros, Gilberto Freire, em Casa Grande e Senzala. Por outro lado, a própria história do processo abolicionista nos mostra a existência de um grande número de negros educados, ocupando papel de destaque na sociedade brasileira no século XIX e organizando as formas de resistência e luta contra a escravidão. Os abolicionistas famosos eram exemplo da escolarização dos negros: André Rebouças, José do Patrocínio, Luis Gama, entre outros. Na Bahia, Teodoro Sampaio, Juliano Moreira, Manoel Querino e, até, o Barão de Cotegipe, ministro conservador do Império, escravista, eram negros.

Desde a chegada da corte portuguesa, em 1808, ao lado da ênfase evidente no Ensino Superior, até porque até então este não existia, se dá início à organização de uma educação para a formação de artífices. Naquele momento, conseguir mão de obra livre bem preparada era difícil, por conta da plena vigência da escravidão e por ter sido vedada, até então, o próprio desenvolvimento da manufatura (a não ser de bens simples), no Brasil. A própria instalação do Exército português, então em guerra com a França (lembrar que Brasil ocupa Caiena, até o tratado de Viena; e o Uruguai, até 1828), demandava uma produção em metalurgia que, até então, era bastante precária no Brasil. Em 1810, é criada na Corte uma companhia militar de soldados artífices, anexa ao Regimento de Artilharia da Corte, que deveria formar 60 ferreiros e serralheiros. Antes, fora contratado um mestre fundidor

Lembrar, no final do século XVII, a questão da exclusão dos moços pardos dos colégios jesuítas, resolvida em 1685 favoravelmente a eles pela Cédula Real que garantia a sua matrícula. 
alemão para formar 66 operários, que, no entanto, teriam sido atraídos por pequenas fundições.

Assim, a primeira vertente da formação para o trabalho de iniciativa do Estado foi a via militar. A segunda, a reforma e desenvolvimento dos estaleiros, em 1811, inclusive visando formar projetistas e desenhistas voltados para a arquitetura naval. A terceira vertente, foi o reordenamento de orfanatos existentes, como o Colégio dos Órfãos de São Joaquim, na Bahia. Este orfanato, que existia desde 1798, foi estatizado em 1919, aos moldes da Real Casa Pia de Lisboa, sendo-lhe doado o antigo prédio do Noviciado dos Jesuítas. Estava destinado a recolher órfãos e desvalidos e dar-lhes ensino profissional e se torna o primeiro de uma longa série de instituições voltadas para tal (MATTA, 2006).

A quarta via para a formação de artífices se dá pela via do desenvolvimento das artes. Após o final da guerra com a França, em 1816, uma missão artística francesa composta por 10 artistas, vem ao Brasil, coordenada por Lebreton, presidente perpétuo da Seção de Belas Artes do Instituto de França. A partir de sua presença, se pensa a Academia de Belas Artes, criada afinal em 1820 (CUNHA, 1979), que inicialmente deveria ter um duplo papel: a formação para as "belas artes" e para as artes mecânicas, na formação de artífices.

\section{EDUCAÇÃO DA POPULAÇ̃̃O NEGRA: A SITUAÇÃO NO FINAL DO IMPÉRIO}

Em 1872, quase no final do Império, quando da realização do primeiro Censo Demográfico, 79,44\% da população livre era analfabeta, na Bahia. Se deste total retirarmos os menores de 5 anos, temos um grau de analfabetismo da ordem de $75,88 \%$. A situação do Brasil era pior, então com $81,43 \%$ da sua população livre analfabeta, o que correspondia a $78,11 \%$ da população de 5 anos e mais. Com índices de analfabetismo maiores que o da Bahia estavam 13 das províncias então existentes, estando em melhor situação São Paulo, Rio de Janeiro, Pará, Rio Grande do Sul e Paraná, e o Município Neutro, cidade do Rio de Janeiro, administrada pelo Governo Central.

Se à população livre se acrescentar a população escrava - atingindo, aí sim, a população total - a situação da Bahia se apresenta melhor do que 
a de São Paulo, por exemplo, ou mesmo que a média nacional. Respectivamente, Bahia teria 18,06\% de alfabetizados, São Paulo 16,86\% e Brasil 15,47\%. A condição de escravo praticamente excluía da condição de alfabetizado: em todo o Brasil, apenas 1403 escravos sabiam ler e escrever, sendo 104 em São Paulo, 64 na Bahia e 107 no Rio de Janeiro. Na Corte, a presença de um grupo maior: 329 . Em termos percentuais, sempre abaixo do $1 \%$.

Os dados referentes à condição de alfabetizados ou não, apresentados pelo Censo de 1872, no entanto, não estão cruzados com os dados referentes à cor da pele. Ou seja, apesar de que o Censo estuda cada uma das duas características, não apresenta tabela que permitisse saber quantos brancos alfabetizados, ou quantos negros alfabetizados. $\mathrm{Na}$ busca de precisar o número de negros alfabetizados em 1872, com vistas a tomá-los como ponto de partida para o esforço, porventura existente, de inclusão dos negros à escolarização, nos demos conta de que, no Estado da Bahia, o número total de alfabetizados era às vezes maior ou aproximado do total de brancos existentes, o que, de por si denotava a presença de um contingente negro alfabetizado considerável.

O caso mais evidente era o de Salvador, em que havia 40.915 alfabetizados para uma população total branca de 38.374 pessoas. Abatendo do total da população branca e da população negra livre (Outra = pretos e pardos) o contingente de 0 a 5 anos, apresentado no documento que forneceu os dados do Censo (IBGE, 1949). Estes eram, para os brancos, $12,51 \%$ e, para os não-brancos, $13,6 \%$. Com as novas populações-alvo da alfabetização, tomamos como hipótese um índice de alfabetização da população branca da ordem de $65 \%$, bastante acima dos totais apresentados pelo Censo para o total da população livre.

Com isso, obtivemos um saldo numérico de alfabetizados não brancos, o que nos permitiu calcular um percentual de alfabetizados não brancos para o total do Estado, para Salvador, para o Recôncavo e para os municípios com mais de 20.000 , entre 20 e 10.000 habitantes e com menos de 10.000 habitantes. Os resultados deste exercício podem ser vistos na Tabela 1. 
Tabela 1 - Bahia - 1872

Percentuais de alfabetização da população livre nos municípios, segundo número de habitantes ${ }^{2}$.

\begin{tabular}{lllllll} 
& Salvador & Recôncavo & +20.000 & $10 / 20.000$ & 10.000 & BAHIA \\
Pop. total & 129.109 & 363.623 & 835.559 & 255.513 & 159.435 & 1.379 .616 \\
Escravos & 16.468 & 58.448 & 96.931 & 31.253 & 23.172 & 167.824 \\
Total Livre & 112.641 & 305.175 & 738.628 & 224.260 & 136.273 & 1.211 .792 \\
Branca & 38.374 & 79.007 & 197.221 & 59.208 & 29.948 & 324.751 \\
\hline Outra & 74.267 & 226.168 & 541.407 & 165.052 & 106.315 & 887.041 \\
Alfabetiza. & 40.915 & 66.711 & 134.237 & 50.139 & 22.881 & 248.172 \\
\%A. Total & 36,00 & 20,84 & 18,25 & 22,33 & 16,30 & 18,0 \\
\%A. Livre & 41,27 & 24,84 & 20,65 & 25,4 & 19,08 & 20,48 \\
\%Ñbranca & 29,7 & 10,8 & 4,6 & 17,44 & 6,14 & 8,28 \\
\hline
\end{tabular}

Fonte: IBGE (1949). Cálculos da autora.

Entendemos, é claro, que este percentual hipotético de $65 \%$ de alfabetização da população branca não se aplicaria uniformemente a todos os municípios do estado. No entanto, em favor de nosso raciocínio, verificamos que se tomássemos, por absurdo, um percentual de $80 \%$ de alfabetização da população branca de 5 anos e mais, ainda assim haveria um saldo de alfabetizados não brancos em diversos municípios, como Salvador, Santo Amaro, Jeremoabo, Lençois, Purificação, Macaúbas, Alagoinhas, Nazaré, Maragogipe, Tapera (Amargosa), Vila Nova da Rainha (Senhor do Bonfim), Camisão, Feira de Santana, Abrantes, Mata de São João e Itaparica; no universo dos municípios com mais de 20.000 habitantes e dos municípios do Recôncavo.

O número de alfabetizados é menor nos municípios que concentram grande população escrava, ou seja, onde ainda a atividade econômica principal é a lavoura açucareira, como em São Francisco do Conde. O fenômeno se repete em diversos distritos de Salvador. Assim, no momento do Censo de 1872, ainda sob a escravidão, existia um contingente considerável de não brancos alfabetizados. Não se estaria, portanto, partindo de um zero, neste esforço de incorporar à chamada civilização letrada a população liberta.

2 Na hipótese de que $65 \%$ da população branca de mais de 5 anos estivesse alfabetizada. 
A presença destes negros alfabetizados, entretanto, não afasta a evidência de que a grande maioria da população não sabia ler e escrever. No entanto, o escasso índice de alfabetização da população brasileira e baiana, não provoca, na República que se inicia, políticas massivas de oferta de escolarização da população em idade escolar nem, sobretudo, dos adultos. E, apesar disto, o saber ler e escrever é utilizado como filtro para a cidadania plena, mantendo-se a proibição do voto dos analfabetos. Em nosso entendimento, esta lacuna significa uma forma de exclusão da cidadania de enormes parcelas da população, majoritariamente dos negros ${ }^{3}$. Na análise que se segue, veremos como os negros, agora artífices, artistas "trabalhadores", operários, vão lutar por sua educação e pela de seus filhos, conscientes de que estavam lutando por cidadania.

\section{PÓS-ABOLIÇÃO E A “EDUCAÇÃO DOS TRABALHADORES”}

$\mathrm{Na}$ República, desaparecem as organizações voltadas para a Abolição da Escravidão, proclamada um ano antes. A discussão sobre liberdade se esgota, e as reivindicações organizadas em torno ao ser escravo, negro, desaparecem. As chamadas "classes trabalhadoras" buscam organizar-se, de diversas formas, que muitas vezes coexistem harmonicamente: criam Corporações, Caixas Beneficientes, Sociedades de Socorros Mútuos, Sociedades de Resistências, Sindicatos e Bolsas de Trabalho, bem como ligas operárias. A Câmara ou bolsa de trabalho se encarregava, inclusive, de realizar pesquisa de mercado de trabalho ${ }^{4}$. Outras organizações tomam forma reivindicatória e política. Em 1890, no Rio de Janeiro o Centro Artístico se transforma em Partido Operário; seu presidente será o Tenente José Augusto Vinhaes, líder dos operários a Estrada de Ferro Central do Brasil. O Partido Operário de Fortaleza foi também de 1890. Seu programa de reivindicações era: 8 horas de trabalho, redução das horas de trabalho de mulheres e crianças, democratização do capital e habitação higiênica, alfabetização. Reivindicavam, também, que fossem ministradas aulas noturnas aos operários.

Para uma leitura mais aprofundada a respeito, ver MENEZES, 1997a, 1997b, além de BARBOSA, 1982, 1985, 1989. Exemplo de bolsa de trabalho foi organizada na Bahia por Manoel Querino e outros artistas para a contratação e execução de obras, inclusive públicas. Denominava-se Liga Operária. 
Em 1892 se dá a realização do I Congresso Socialista do Rio de Janeiro, do qual participam 400 pessoas ocasião em que foi fundado o Partido Socialista Brasileiro. Em São Paulo, criado o Jornal A questão Social. Outro Jornal, O socialista, tem como lema "Operários de todo o mundo - Unívos! Um por todos, todos por um”. Na mesma ocasião, foi lançado o Manifesto do Partido Socialista do Rio Grande do Sul em que se propõe o fim da desigualdade. A República, naquele momento, era a expressão da desigualdade, um povo que trabalha, paga e sofre, o povo pobre, o proletariado; outro que usufrui o trabalho, o capitalismo e o militarismo. Propunha também instrução gratuita, em todos os graus acompanhada de proibição do trabalho de modo geral para menores de 14 anos. Para menores entre 14 e 18 anos, somente 5 horas de trabalho.

Outro Partido Socialista foi criado em 1902. Entendia que contra a exploração dos patrões, se devia contrapor a exigência dos assalariados. Para eles, a felicidade do indivíduo estaria na proporção direta do bemestar econômico de todos os membros da sociedade. Seu programa mínimo propunha: eleições aos domingos e permanente qualificação eleitoral, 6 horas de trabalho para menores entre 14 e 16 anos e proibição do trabalho do menor de 14 anos. Além disto, instrução baixa à custa do Estado e criação de escolas noturnas. Organizado o primeiro Congresso Operário Brasileiro, este propôs a manutenção, pelos sindicatos, de uma escola laica. Funda-se um Partido Operário Socialista em 1908 - e outro em 1909. Repetem-se as diretrizes gerais - promover conferências socialistas e criar escolas.

Em 1912, realiza-se um Congresso Operário do qual participam delegações de vários Estados. Seria o quarto: 1892 o primeiro, 1902 o segundo e 1906 o terceiro. Dele participam 66 associações, da Bahia inclusive. Em 1913, organiza-se a Confederação Operária Brasileira. Atacam teses reformistas de 1912 e propõem a realização de um Congresso pela Paz contra a Guerra. Paz real, baseada na efetiva solidariedade internacional. As greves operárias se multiplicam em todo o período da República Velha - Rio, São Paulo e outros Estados (CARONE, 1972).

Este era o lema também do Jornal do Centro Operário, na Bahia - Arquivo Municipal de Salvador, Caixa sobre Centro Operário. 


\section{SALVADOR: O PÓS-ABOLIÇÃO E A LUTA PELA SOBREVIVÊNCIA}

$\mathrm{Na}$ Bahia, não houve um crescimento da urbanização como resultado imediato da Abolição e sim o fortalecimento da atividade rural, com a dispersão da população, uma queda na atividade econômica, em crise permanente desde 1860, crise esta que se acentua após a Abolição e que vem se caracterizar como estagnação a partir de 1920. Os ex-escravos passam a ocupar-se, prioritariamente com a agricultura de subsistência, associada ao cultivo de produtos como o fumo como produto de fundo de quintal. Teria havido, assim, a emergência generalizada de um campesinato, num movimento foi chamado de "pressão dos dominados, livres ou escravos, na direção de um campesinato ou assalariamento", quando todos desconfiavam de qualquer tipo de subordinação. Livres, os homens preferiam "mariscar" que trabalhar em atividade assemelhada a escravidão (BAHIA, 1978).

Ao lado deste processo, tem início um período de pobreza acentuada, com conseqüências sobre o nível de qualidade de vida das classes populares em geral, mas de forma mais direta dos ex-escravos. A demanda imediata pela sobrevivência passa a ser o centro da vida, a luta principal, neste momento de reorganização total da vida dos negros, guiando-lhe inclusive a sua inserção na cidadania. Assim, a luta pela liberdade se transforma em luta pela igualdade, a partir da busca do direito básico, mínimo: a sobrevivência.

Após a Abolição e em seguimento a Proclamação da República, operase uma mudança significativa nas lutas da população baiana. A luta do conjunto da população pobre (onde estavam representados, majoritariamente os negros ex-escravos e seus descendentes) passa a se desenvolver em duas vertentes: 1- as lutas por melhores condições de trabalho, de salário, etc., através da organização de mutuais, sindicatos, associações, etc., e, 2- lutas visando melhorar as condições de vida.

Tomando Salvador como locus de análise, o professor Mário Augusto Santos estuda o período da República Velha e do pós Abolição. Para ele, neste período, predominou em Salvador a segunda forma de luta, como forma de organização de um "movimento pelo trabalho". O autor organiza seu trabalho analisando, de um lado as organizações voltadas para o "trabalho" e, de outro, os movimentos voltados para a qualidade de vida (SANTOS, 2001). As organizações mais importantes que surgem, no período 
são: o Centro Operário da Bahia, criado em 1894 depois da extinção do Partido Operário, de cuja criação participara o abolicionista e republicano Manuel Querino, sempre presente; e a Associação dos Empregados do Comércio. O Centro Operário, que vamos analisar em seguida como uma das instituições que os negros utilizaram para instruir-se, tinha na instrução a sua bandeira máxima, como maneira de atingir a cidadania. Se o seu papel de representação dos trabalhadores é, na opinião do autor, imperfeita, ele tem, além do aspecto da ênfase na instrução, a preocupação com a participação político-eleitoral mesmo sem partidarização, a tentativa de representação dos trabalhadores e a participação no movimento pela qualidade de vida da população.

Segundo os estudiosos da República na Bahia, o movimento dos trabalhadores, como conjunto, foi fraco em toda a Primeira República, em decorrência da insignificância numérica da mão-de-obra fabril, o grande contingente de pequenas unidades mais artesanais que industriais, etc, e, até, pela não influência do movimento anarquista, forte no Rio de Janeiro e São Paulo dado a presença forte de imigrantes italianos. Já os movimentos contra a carestia tiveram maior vulto, tendo em vista o alto custo da alimentação e, como conseqüência, as ameaças a sobrevivência física dos trabalhadores. Sua principal organização é o Comitê Popular contra a Carestia de Vida, criado em 1913 e presidido por Cosme de Farias, também presidente da Liga contra o Analfabetismo, que vamos analisar depois. O Comitê se reunia ordinariamente no Centro Operário e no Montepio dos Artistas. Os momentos mais fortes deste movimento parecem ter sido, em 1913, (embora o autor registre o seu crescimento desde o início da República). Em 1913 o movimento dura de $1^{\circ}$. de março a 25 de abril, e incluiu comícios, abaixo-assinados, e passeatas onde se conduziam cartazes com dizeres como "O povo tem fome" e "Abaixo a exploração".

Os movimentos se sucedem em 1914, 1917, etc. e o autor os classifica entre espontâneos e organizados. Entre os primeiros, inclui quebra de bondes, em 1901, o "fecha-fecha” e o “quebra-lampeões”, em 1904, ataque à Light (companhia de luz e transportes) e depredações da cidade em 1909, o assalto a casas comerciais, em 1914; incêndio de carne e bonde e fechamento de padarias em 1927 e depredações contra a Linha Circular (também de transportes) em 1930. Protestava-se, portanto, contra aumento de impostos, do preço dos transportes, da carne, do pão, da luz. 
Já os movimentos que são considerados organizados tomaram a forma de comícios, passeatas e reuniões, entendidos como "forma republicana de protesto" por excelência. Estão ligados também às eleições diretas e a ampliação do colégio eleitoral (como também todas as reivindicações de educação para todos, de escola noturna, de escolas sindicais). São movimentos de massa, que reúnem grande número de pessoas - chegam a acontecer movimentos de 4 mil participantes e mais - sendo que as informações quanto a seus participantes indicam serem eles "pessoas do povo", oriundos das classes populares, trabalhadores, filhos do povo, etc. Entre os mortos e feridos do conflito de 1917, quando aconteceram tiroteios com a polícia, dos 21 atingidos estavam estudantes, operários, carregadores, carapinas, pedreiros, marceneiros, etc.

Refletindo sobre o crescimento destes movimentos na Salvador do período Pós-abolição, Primeira República, o Prof. Mário Augusto diz que seria difícil encontrar as razões para este crescimento. Pergunta-se se teriam piorado as condições de vida dos setores majoritários da população ou se as remunerações haveriam entrado em maior descompasso com os preços, comparativamente aos anos anteriores. Sobretudo, pergunta-se se a presença dos ex-escravos recentes, aumentando o número dos que deveriam prover seu próprio sustento, não teria ocasionado um agravamento, em conjunto, das condições de subsistência da cidade. E responde que, provavelmente, os movimentos poderiam ser explicados por uma possível baixa geral do nível de vida das classes populares no Pós-abolição em decorrência de um contingente de mão-de-obra livre desqualificada, chegando a um mercado de trabalho com pequena capacidade de absorvê-la. Em conseqüência, teriam aumentado os contingentes do sub-proletariado, num momento em que a conjuntura de preços estava em alta. Articula, assim, os movimentos, à população negra baiana (SANTOS, 2001).

\section{As INICIATIVAS POR EDUCAR-SE}

Os membros das classes populares na Bahia não só acreditavam no "papel redentor" da escola, como lutaram por ela, tomando a iniciativa de criar classes escolares em suas organizações, para si e seus filhos. A tal ponto era valorizada a instrução que não se encontra, nestas lutas ou pelo menos nos registros que se fez delas, nenhuma posição contra a exigência da 
alfabetização para a cidadania ativa, da exclusão do analfabeto do direito ao voto, pelo menos nesse período Republicano "lembrar que, durante a discussão da Reforma Eleitoral, no Império, parcela do partido liberal, em especial os abolicionistas radicais, protestou contra a mesma exclusão", a ponto de que nos ocorre pensar de que este é um ponto em que os excluídos estiveram sob a hegemonia de quem os excluía ou, simplesmente, do instrumento de sua exclusão.

No período imediatamente após a República, dentro desse entusiasmo pela educação, diversas organizações que pretendiam representar os trabalhadores organizaram escolas primárias e cursos noturnos. A primeira delas, que vem do Império, do período da extinção da escravidão, foi o Liceu de Artes e Ofícios. O Liceu da Bahia era uma associação da sociedade civil da qual participavam "artistas" e artífices, estava voltado para a formação de mão-de-obra livre para tarefas manuais ou manufatureiras; pretendia ainda funcionar como sociedade de ajuda mútua, além de dar educação aos filhos daqueles artífices. Sua criação estava também vinculada à formação dos filhos livres dos escravos, e seus estatutos teriam sido organizados por advogado ligado às causas dos escravos e criador de sociedades libertadoras na Bahia.

Suas aulas foram abertas a partir de maio de 1873 para 166 alunos e tinha como objetivo dar, além da educação profissional, "instrução literária”, ou seja, formação geral, para seus associados e os filhos deles. Os alunos que não fossem filhos dos sócios recebiam instrução gratuita, em troca do subsídio governamental. Em 1891, contava com 1704 sócios. Além da formação para o trabalho, mantinha duas classes diurnas de primeiras letras "uma para cada sexo" e outra noturna, para adultos. Segundo consta, o Liceu teve também grande importância na vida cultural da cidade, pela formação de pintores, escultores, etc. Relatórios de Atividade do mesmo liceu mostram um crescimento da instituição no início do século: em 1900, a matrícula chegava a 860 alunos e introduzia-se o ensino de contabilidade e técnica mercantil ${ }^{6}$.

\footnotetext{
Em artigo publicado no D.O. do Centenário da Independência do prof. Alberto Assis, encontramos o registro de que o Liceu de Artes e Ofícios, em 1923, seguia mantendo as classes de educação primária, com 178 alunos, fora as classes noturnas e profissionalizantes. Como instituição de ensino profissionalizante, teve sua importância ressaltada durante o Estado Novo. Mantinha também classes noturnas de educação supletiva.
} 
Uma segunda instituição, com características semelhantes às do Liceu, surgida de uma dissidência dele, foi a Escola de Belas Artes, incorporada, em 1945, à Universidade Federal da Bahia, quando da sua criação, segundo Acácio França, A Pintura na Bahia, D.O. do Centenário. Mantinha, além dos cursos de pintor, escultor, arquiteto, empreiteiro e desenhista, duas escolas primárias. Segundo a Memória Histórica de 1892 a que nos referimos, tinha de 150 a 200 alunos anuais. Em 1923 tinha 68 alunos matriculados em escola primária.

Outra instituição mantida pelos trabalhadores que também oferecia educação escolar, fundada já no período inicial da República, foi o Centro Operário. Criada em substituição ao Partido Operário, pretendia representar os trabalhadores sem ter, contudo, caráter partidário. Tem natureza diferente do Liceu, este na sua origem uma entidade educacional (embora também beneficiente). No entanto, o Centro Operário que vai participar e às vezes liderar os "movimentos contra a carestia", face ao alto custo de vida na Bahia da Primeira República. De outro lado, nos seus estatutos, pretende assumir uma face francamente educacional, abrindo espaço para a escolarização dos trabalhadores, seus filhos e também outras crianças, inclusive menores abandonados.

Analisamos a Constituição do Centro Operário (seus estatutos), dois requerimentos à Intendência de Salvador e ao Conselho Municipal e um exemplar de seu Jornal A Voz do Operário, contendo relatório do ano de 1896. O jornal adota como dísticos, de um lado "Proletários do mundo uní-vos" e, de outro, "Todos por um, um por todos", como outros vinculados aos socialistas no início do século XX. Em editorial, dirige-se "Às classes operárias" como "Artistas, filhos do trabalho, alheios da fortuna, excluídos das altas posições, e perseguidos da pobreza e da falta de instrução, vítimas das extorsões, do despotismo, do preconceito e da prepotência - origem da escravidão" (A VOZ..., 1897). No relatório da gestão anterior, ressalta a criação do curso primário diurno, com freqüência de 50 alunos. Já então existia o curso noturno. O requerimento de 1900 tem como objetivo solicitar subsídio governamental para as escolas primárias que mantém, diurnas e noturnas, com a finalidade de dar educação geral e moral e cívica às crianças e adultos - "desde quando a instrução primária é um elemento indispensável da grandeza dos povos e é tão necessária à Civilização quanto 
o ar é necessário à vida do homem". Apresenta, para fundamentar o pedido, estatística das matrículas oferecidas, de 1895 a 1899 :

Tabela 2 - Bahia - Matrícula em escolas do Centro Operário (1895 - 1899)

\begin{tabular}{llll} 
ANOS & NOTURNA & DIURNA & TOTAL \\
1895 & 48 & - & 48 \\
1896 & 50 & - & 50 \\
1897 & 59 & 48 & 107 \\
1998 & 83 & 120 & 203 \\
1899 & 90 & 123 & 213 \\
\hline
\end{tabular}

Fonte: Adaptado do requerimento manuscrito do Centro Operário ao Conselho Municipal de Salvador (1900).

Com base nesses dados, apresenta o total das despesas, solicitando subsídio governamental para parte delas pagamento de professor, porteiro, despesas com iluminação noturna - querozene e espermacete, naquela época, o curso noturno se fazia à luz de velas e de candeeiros.

Entretanto, essa prioridade dada à educação pelo Centro Operário aparece mais claramente nos seus estatutos. No capítulo referente a sua finalidade, fala, de saída, na aquisição de um prédio que tivesse proporções para abrigar as reuniões do Centro "e a construção das oficinas e aulas que o mesmo tem por fim fundar” (CENTRO..., 1896) ${ }^{7}$. Estava prevista no mesmo estatuto a criação dos cursos primário, secundário, acessório e técnico. A Constituição faz, inclusive, um esboço de currículo para os mesmos:

Primário - conhecimento rudimentar da língua portuguesa.

Secundário - dividido em tres seções:

$1^{a}$ - Portugues, Frances, Matemática, Desenho de perspectiva, Geografia do Brasil, História das artes e economia política.

$2^{a}$ - Latim, ingles, alemão, filosofia, história universal, geografia em geral e mecânica.

7 Arquivo Municipal de Salvador, Caixa do Centro Operário. 
$3^{\mathrm{a}}$ - Curso accessório - Química e física aplicada às artes, Zoologia, botânica e mineralogia.

O curso técnico deveria constar de "noções genéricas das Artes e Ofícios. (CENTRO..., 1896).

Estava prevista a criação de uma Biblioteca, de um recolhimento de menores, a construção de oficinas e até o envio, para o exterior, dos alunos “mais inteligentes e habilitados". Observava, entretanto, o artigo $5^{\circ}$ que apenas teriam direito ao ensino secundário aqueles que se destinassem ao curso técnico; os demais teriam direito apenas ao curso primário. Propunhase, por fim, a criar cursos primários e noturnos nos diversos distritos paroquiais em que se organizava. Um longo programa educacional (CENTRO..., 1896).

O Centro Operário, portanto, mantinha, em 1900, cerca de 120 alunos do curso primário, mais os do noturno. Segundo Assis (1923), seu curso primário tinha 180 alunos matriculados.

Em suma, na cidade de Salvador que tinha, em 1896, no ensino primário público, pouco mais de 4.000 alunos matriculados, as três instituições: Centro Operário, Liceu de Artes e Ofícios e Escola de Belas Artes matriculavam cerca de 450 alunos mais, o que tinha algum significado. No entanto, em 1923, a matrícula primária mantida pelas três instituições pouco tinha crescido, perdendo significado no conjunto da oferta pública.

Outro rumo tomado pelo movimento popular com relação à questão da oferta de escolas, foi a fundação da Liga Baiana contra o Analfabetismo, coordenada, por muito tempo, pelo Major Cosme de Farias, líder do movimento contra a Carestia e dos movimentos de protesto antes de 1920. A Liga, que era formada inclusive por educadores como Isaías Alves, depois criador de escola privada, Secretário de Educação no Estado Novo e fundador da Faculdade de Filosofia da Bahia, tinha um papel muito mais de agitação e propaganda em torno do problema da alfabetização dos adultos. Foi criada em 1916, época em que se criaram outras ligas semelhantes no Brasil, e dedicava-se a distribuir "cartas de ABC", tabuadas e o "livro do Bom Homem Ricardo". Em 1925, encontrei correspondência de Cosme de Farias, então presidente do Liceu de Artes e Ofícios, ao Governador Góes Calmon, solicitando o apoio deste à Liga, que estaria em decadência. No entanto, ela continua existindo até 1971, quando do seu falecimento. 
O outro líder popular que circulou em torno da questão foi Manoel Querino, professor de desenho do Liceu de Artes e Ofícios e do Colégio dos Órfãos de S. Joaquim. Pintor e arquiteto, estudou arquitetura na Escola de Belas Artes, Manoel Querino foi fundador do Partido Operário, anterior ao Centro Operário. Querino, negro, abolicionista e republicano, foi vereador da capital e representante (delegado) da Bahia no Congresso Operário Brasileiro de 1892. Querino era liderança, desde a década de 1970, da "classe operária" baiana, articulada com a ala radical do abolicionismo. Fundou, com outros militantes, o Jornal O Trabalho, em 1892. Criador da Liga Operária, em 1875, a qual, a exemplo do que acontecia em outras cidades, funcionava como "cooperativa de trabalho" na área da construção civil, entrando em concorrências e empreitando obras públicas. Criou também um jornal da Liga Operária, que durou de janeiro de 1877 a fevereiro de 1878. Em 1887, criou outro jornal, A província, que durou um ano. Escreveu também na Gazeta da Tarde, jornal do abolicionista Pamphilo de Santa Cruz. Na década de 1890, ter-se-ia desencantado das atividades político-partidárias da República na Bahia. A partir daí, se volta para atuação na Sociedade Protetora dos Desvalidos, criada em 1835 como Junta de Alforria, ou seja, espécie de organização de auxílio mútuo de escravos para sua libertação, segue existindo até hoje com a peculiaridade de que só admite negros em seu quadro social; e para o estudo da história das artes na Bahia, publicando livro sobre o assunto em 1909. Passa a escrever sobre "usos e costumes" da Bahia, publicando livro sobre "A Bahia de Outrora".

Por fim, em 1915 e 1916 realiza uma série de trabalhos sobre a presença africana na Bahia, sendo o primeiro a retomar o assunto, após a morte de Nina Rodrigues (veja-se que o principal livro de Nina, Os africanos no Brasil só vem a ser publicado em 1937). Nos $5^{\circ}$ e $6^{\circ}$ Congressos de Geografia, organizados pelo Instituto Geográfico e Histórico, apresenta trabalhos intitulados A raça africana e seus costumes na Babia e O Colono preto como fator de civilização nacional. Em nossa opinião, a importância de Manoel Querino vem de seu papel de elo de ligação entre os movimentos abolicionista, o republicano popular, o movimento operário e, por fim, de um movimento de resgate das raízes negras. Querino é o primeiro autor que, desde estudos etnográficos, começa a afirmar o valor positivo da presença do negro no Brasil, protestando expressamente contra "a presunção 
(racista) da inferioridade da raça negra, que atribuía a boçalidade a qualidade congênita" (QUERINO, 1955). Argumenta que o estágio de conhecimento em que se encontrava o negro era resultado da opressão do forte contra o fraco, efeito da ação do "português, que fez do africano a máquina inconsciente do trabalho" (QUERINO, 1955).

\section{MúSICA, BANDAS; ABOLICIONISMO E MUTUALISMO}

Os estudos desenvolvidos sobre a presença e a atuação de um mestre de bandas da Bahia - mais especificamente de Cachoeira, no Recôncavo, irradiando-se por outras cidades próximas, Mestre Manuel Tranquillino Bastos, maestro fundador de vários cursos de instrução de música em Paris, nos trouxeram dados novos sobre a participação de negros, artistas, no movimento abolicionista e, no Pós-abolição na organização do trabalho. No material existente em seu acervo, no setor de obras raras da Biblioteca Central do Estado da Bahia, por Juvino Alves ${ }^{8}$, dentre os manuais de ensino de música que escreveu, coletou e traduziu, encontra-se material sobre a organização de bandas enquanto Sociedades Musicais Civis, nos moldes praticados em Paris. O Manual completo do Diretor de Música ou Tratado de Organização das Sociedades Musicais Civis por ele traduzido e adotado como guia de ação, fala, além do papel do ensino da música e das letras, da função de apoio mútuo, caridade e filantropia, inclusive pela mobilização em socorro a pessoas e situações de calamidade (CLODOMIR, [18-]).

Bastos atuava como compositor, educador musical, arranjador, instrumentista, escritor, teórico musical, político, pensador e abolicionista. Nascido da união de um português com uma negra alforriada, ainda menino aprendeu a tocar clarineta e se incorporou ao Coro de Santa Cecília, a padroeira dos músicos e, mais tarde, à Banda Marcial São Benedito, formada basicamente por músicos negros (RAMOS, 2000).

De acordo com sua autobiografia, escrita em seu Caderno de Anotações, entre 1910 e 1924, Tranquillino foi o responsável pelo surgimento de seis a oito filarmônicas, criando ou organizando-as. Dentre elas estão a Banda Musical da Sociedade Euterpe Ceciliana e sua orchestra religiosa, que mais tarde tornou-se a Sociedade Cultural Orpheica Lyra Ceciliana (1870), a

\footnotetext{
8 Ver SANTOS FILHO, 2005 e 2006.
} 
Filarmônica Comercial e a Harpa Sanfelixta, da cidade de São Félix, a Banda da Sociedade Filarmônica Victoria, de Feira de Santana e a Sociedade Musical Lyra São Gonçalense, de São Gonçalo dos Campos, hoje todas centenárias e algumas delas extintas, como a Sociedade Filarmônica Victoria, a Harpa Sanfelixta e a Filarmônica Comercial. A primeira Banda regida por Tranquillino pertencia à Sociedade Recreio Cachoeirano.

Esteve sempre à frente dos movimentos sociais e políticos de sua cidade natal, Cachoeira-Bahia e de seu país. Isso pode ser verificado através de algumas de suas obras como o Hymno Abolicionista (1884) , Hymno 13 de Maio (1888), Hymno da Cachoeira (1922), ou o Dobrado Navio Negreiro, homônimo do poema de Castro Alves, seu contemporâneo. Essas obras eram compostas como forma de protesto e repúdio à escravidão expressado através de seus escritos em forma de crônicas, que versavam ainda sobre assuntos diversos como arte, religião, cultura, vida, morte, comportamento social, música, e vários outros temas humanísticos. Essas crônicas eram publicadas numa coluna dominical denominada de Cartas Musicaes no semanário O Pequeno Jornal, entre 1924 até sua morte, em 1935, e que circulava em Cachoeira. Tais crônicas foram arroladas por Tranquillino em um livro, não publicado e intitulado Minhas Percepções. No dia 13 de maio, anos seguidos, escreveu sobre a importância da abolição da escravatura. Um trecho de uma destas crônicas diz o seguinte:

\section{O 13 de Maio.}

O 13 de Maio, é a abolição do crime e alforria dos martyres. Entre os usurpadores da liberdade, que se constituíram senhores, e os usurpados que se curvaram como escravo, ha n'elles duas altitudes em contrasto. Os primeiros, foram infelizes pela perversidade diabólica do seu commercio; os segundos, os felizes por tormentados! Effectivamente, não ha razão para se occultarem ás homenagens festivaes, dessa dacta gloriosa;os martyres da pervorsidade humana, cedendo á elles (os infelizes) a vanguarda das festas da redempção moral e phisica, como se o piccado fosse virtude e a virtude peccado. Avante pois ao "13

\footnotetext{
Hymno Abolicionista (1884) (Música de Manuel Tranquillino Bastos e Poesia de Furtunato Tinoco, Bingre e Thomé) Brasileiros cantai liberdade./Nossa pátria não quer mais escravos./Os grilhões vão quebrar-se num povo/De origem somente de bravos./Em tudo inspira a santa voz da liberdade /No mar, nas selvas, Na immensidade/E já no céu se vê escripto em letras d'ouro/Redempção ao captivo É seu thesouro. /O jugo do servilismo/Róle em pedaços no chão/Pise altiva a liberdade sobre o pó da escravidão/Abaixo a crença do velho atrazo/ Que dos captivos venceu-se o prazo/Quebrem-se os ferros da tyrania, sejamos todos livres um dia. Nosso throno ha de livre, altaneiro, Alvorar o liberto pendão/E Dom Pedro sentado no throno/ Bradará liberdade à nação. /Rompa-se o verso infamante/ A custa de esforços mil./Deus não quer, nós não queremos q'haja escravos no Brazil./ De Rio Branco surgio a idéia,/De Souza Dantas a epopéia./Pedro Segundo Tua equidade/ Seja a coroa da Liberdade.
} 
de Maio", festejemos a inhumação do crime, do erro e da perversidade, e a exhumação e a resurreição do Direito e da Justiça (BASTOS, [193-?]).

Segundo um seu biógrafo, Ramos, Tranquilino foi no Recôncavo “O Maestro da Abolição".

Abolicionista ferrenho, saiu às ruas de Cachoeira na noite de 13 de maio de 1888 à frente da Lyra Ceciliana - filarmônica fundada por ele 18 anos antes com o nome de Euterpe Ceciliana -, arrastando mais de duas mil pessoas, a maioria negros recém-libertos, comemorando a assinatura da Lei Áurea. Aquele momento histórico seria retratado por ele na composição Airosa Passeata, uma das mais conhecidas e de maior presença no repertório das filarmônicas do interior baiano, principalmente no Recôncavo (RAMOS, 2000 apud SANTOS FILHO, 2003a, p. 21).

Ainda sobre o repúdio à escravidão ele escreveu:

Alleluia pelo 13 de Maio.

Cantemos o seu Hymno, pela abolição do crime, e da resurreição do Direito e da Justiça. Hosana pela Victoria da civilisação contra a ignorância selvagica. Não mais se compram nem se vendem mais; viva, viva a segunda felicidade da nossa Pátria; maior que a primeira e muito mais a terceira. Foi a mão da Liberdade abrindo o Palácio da Independencia. Hosanas por tudo isso! (BASTOS, [193-?]).

Tranquillino Bastos conviveu com nomes da política e da arte da Bahia, dentre eles: José dos Santos Barreto, Eduardo Mendes Franco, Francisco José da Costa, João Manoel Dantas, José de Souza Aragão, Ernesto Simões Filho, Monsenhor Elpídio Ferreira Tapiranga, Carlito Onofre, e o distinto poeta Sabino de Campos que escreveu a letra do Hymno da Cachoeira, com música composto por Tranquillino em 1922, e que foi apresentado no dia 25 de junho por ocasião das comemorações do Centenário da Independência do Brasil, e em homenagem à participação de Cachoeira na guerra contra as tropas portuguesas (1823). As crônicas escritas por Tranquillino e publicadas em "O Pequeno Jornal" são testemunhos de sua época. Muitos dos seus questionamentos perduram até os nossos dias. Coloca-se numa postura crítica contra o militarismo, a corrupção política, o capital que explora o trabalho, a censura à imprensa, o hábito de comer carne, a destruição da natureza e os maus tratos contra os animais, o coronelismo, a desigual distribuição de renda na sociedade e o voto de 
cabresto. Manifestou sua desilusão com a implantação da República no Brasil. Critica com veemência a violência policial contra os praticantes do candomblé, considerando tais perseguições um descumprimento dos direitos humanos regidos pela Constituição Brasileira. Falou ainda sobre a medicina natural, a homeopatia, o estudo do espiritualismo, da filosofia, conhecimento de línguas, o domínio das letras, tendo um amplo e variado conhecimento musical e uma elaborada apreciação crítica do mundo, documentada em seu livro não publicado Minhas Percepções, o distingue dos demais Mestres.

Tranquillino Bastos legou à posteridade um acervo com cerca de 1.500 (hum mil e quinhentos) documentos musicais entre manuscritos e impressos constando partituras, livros de crônicas e de teoria da música de sua autoria e de outros autores brasileiros e estrangeiros. Formou muitas gerações de músicos em várias cidades da Bahia durante sua longa atividade, que durou mais de sessenta anos, como professor de música, regente, compositor, arranjador, instrumentista, formando músicos de renome, como Irineu Sacramento, que o sucedeu à frente da banda da Sociedade Orpheica Lyra Ceciliana e que conquistou notoriedade como Mestre de Banda na Bahia.

\section{COMUNALISMO, MUTUALISMO, LUTAS POR EDUCAÇÃO. AS DIVERSAS FORMAS DE EDUCAR-SE}

Nossos estudos sobre o período que se segue, entre 1940 e 1980, quando se reintroduz o quesito de cor da pele nos Censos Demográficos brasileiros, mostram que o crescimento do sistema escolar no Brasil acontece de modo desigual no território brasileiro; esta desigualdade se mostra tanto em termos regionais - assimetria entre as diversas regiões brasileiras - como entre o rural e o urbano e entre cidades de maior e menor porte. Estas desigualdades não são explicáveis por elementos tais como maior interesse por escolarização nos estados industrializados, vinculando a vida rural ao desinteresse por escola; ou por diferenças advindas do ambiente mais ou menos inóspito, que vinculam as condições de existência à maior ou menor quantidade de chuva existente. Nossos dados mostram que, no conjunto, são mais pobres os que têm menor acesso à escola. Mostram também que a incorporação dos negros à escolarização é mais lenta e segue reduzida em face aos contingentes dos chamados brancos. 
Os dados são verdadeiros tanto para o Brasil como para a Bahia e, tomado como elemento de comparação por ser o Estado mais rico da Federação, para S. Paulo. Isto nos remete à discussão sobre relações raciais ou sobre desigualdades cuja explicação ultrapassam as causas mensuráveis objetivamente - tipo riqueza, local de moradia, nem por isso pouco injustas - para chegar no campo das causas subjetivas, como a possibilidade da existência de preconceitos e formas de discriminação.

Desenvolvemos ainda um estudo com relatos de vida de negros da comunidade baiana, realizado na década de noventa do século XX, discutindo as suas relações com a educação e a escolarização e as suas formas de aprender e de melhor utilizar o seu aprendizado. Encontramos que na sua resistência à exclusão, desenvolvem formas próprias de luta por melhores condições de vida, que passam por construir solidariedades, formas de organização próprias que no bairro, no trabalho, nas práticas religiosas ou nas formas culturais, os mantêm coesões, travando as lutas do dia a dia, e guardando saberes que lhe vieram de seus antepassados. Na nossa opinião, não são cumpridas as expectativas de autores do início do século XX, como Nina Rodrigues de que estes costumes ou saberes tendiam a desaparecer no prazo máximo de cem anos (NINA RODRIGUES, 1988).

As informações que apresentamos neste texto, referentes ao período anterior ou ao que se segue imediatamente à Abolição da escravidão abrem, para mim, uma nova vertente para estudo, qual seja a presença e liderança de negros baianos em movimentos sociais e organizações vinculados ao trabalho livre, pela via dos artífices, que vão desde a organização de sociedades de ajuda mútua como a criação de jornais, de partidos operários, de escolas e de cursos noturnos vinculados a fábricas. Criam-se instituições como a Sociedade Protetora dos Desvalidos, o Montepio dos Artistas, o Liceu de Artes e Ofícios, a Escola de Belas Artes, o Centro Operário da Bahia; alguns deles organizações apenas de negros, como a Protetora dos Desvalidos, existente desde 1832.

Nos ajudam nesta nova leitura desse momento, além de Mário Augusto Silva, por nós já conhecido, os trabalhos de Foot Hardman e de Maria das Graças Leal sobre Manoel Querino. Os dois encontram, via Manoel Querino, relações desses movimentos e organizações com movimentos e discussões de idéias internacionais. Para Foot Hardman, haveria pontos de intersecção entre Querino e as primeiras gerações do movimento operário 
internacional, encontrando em sua obra "elementos socialistas, libertários, positivistas e jacobinistas" (1988, p. 76). Aponta, nos seus trabalhos sobre as artes na Bahia, "uma certa concepção utópica do papel regenerador da arte/artesanato na sociedade industrial muito próxima, em vários prismas, do movimento de 'artes e ofícios' [Arts \& Crafts] criado pelo socialista libertário inglês William Morris" - que seria uma das fontes básicas do desenho moderno (HARDMAN, 1988, p. 75).

Maria das Graças Leal, em sua tese de doutoramento, afirma que os círculos trabalhistas, dos quais era exemplo a Liga Operária, criada por Querino em 1876, divulgaram no Brasil, durante o século XIX, nova concepção de sociedade, com presença de elementos cooperativo-socialistas. Ela registra a presença no Brasil de influência do socialismo utópico de Proudhon desde a Revolução Praieira de 1848, especialmente pela vertente das sociedades de ajuda mútua, do mutualismo como movimento (LEAL, 2004). Isto, sim, estaria claramente presente nas formas de resistência negra, desde as juntas de alforria e das irmandades, passando pela criação da Sociedade Protetora dos Desvalidos e pela criação de uma série de associações de ajuda mútua desde as sociedades abolicionistas.

Em favor das colocações de Leal, encontramos no exemplar do jornal A Voz do Operário, - órgão oficial do Centro Operário -, de 15 de junho de 1897, além das notícias referentes à estruturação e implantação da escola do Centro Operário e das diversas regionais do Centro, entre as notas da sua seção Noticiário, o registro das comemorações do $1^{\circ}$ de maio de São Paulo e o recebimento de exemplar do Jornal O Socialista, referindo-se ao Congresso Socialista de Paris de 1889. Registra também o recebimento de outro jornal operário - O Eccho Operário, com as notícias sobre as comemorações do $1^{\circ}$ de maio de 1897 . Falando do número especial do jornal referido, comenta tratar-se de "trabalho que muito elevou o valor intellectual dos trabalhadores do futuro partido universal - o Socialismo moderado" (A VOZ..., 1897, p. 4).

A leitura atenta do próprio material de Leal nos mostra a presença de duas vertentes nesse primeiro movimento do trabalho no final do século XIX e início do século XX; um, comandado pelo Centro Operário, comandado por Domingos Silva, mais fortemente ligada "à Ordem e ao Progresso"; outro, liderado por Manoel Querino. Aliás, a militância de Manoel Querino, ao longo de sua trajetória, mostra a sua filiação a uma 
corrente de pensamento que, dentro da Bahia, procura uma maior autonomia das classes “artísticas” face aos partidos então existentes. É assim que atuando dentro do Partido Liberal, assina o manifesto pela criação do Club Republicano na Bahia, em 1877; na criação da Liga Operária em 1876, em defesa de um mercado de trabalho para os trabalhadores urbanos; acompanha Cañyzares na saída do Lyceu de Artes e Ofícios para a criação da Escola de Belas Artes, em 1877, a partir de divergência no interior do Lyceu; no momento de criação do Partido Operário, em 1890, quando passa a atuar no grupo do Conselho Diretório da União Operária. Procura canalizar sua militância do ponto de vista político partidário; chega a propor a criação de um Partido Socialista, não efetivada; candidata-se para o Conselho Municipal e é eleito, uma vez como suplente e outra vez como membro. No entanto, logo deixa de entrar nas listas para eleição.

A partir de 1903, muda sua trajetória como intelectual: passa a incorporar na defesa do trabalho, a militância em favor do "trabalhador nacional", negro, descendente de africanos. Transforma-se assim, de liderança de trabalhadores urbanos livres, em intelectual em favor de uma sociedade mais livre e igualitária. Passa a atuar em um conjunto de associações da sociedade civil: Irmandades, Sociedades de Ajuda Mútua, Escolas de formação profissional como: Lyceu de Artes e Ofícios e Casa Pia e Colégio dos Órfãos de São Joaquim, Instituto Geográfico e Histórico, Sociedade Protetora dos Desvalidos, Sociedade Montepio dos Artistas, dentre outros, além de participar e ajudar na defesa de centros de religião Afrobrasileira, inclusive como Ogãn ${ }^{10}$.

Também Antonio Sérgio Guimarães, em texto denominado Manoel Querino e a construção do pensamento negro no Brasil entre 1890 e 1920, (GUIMARÃES, 2004) procura fazer uma análise do pensamento de Manoel Querino enquanto intelectual negro, a partir da sua produção. Para ele, Querino colocava-se como brasileiro, descendente de africanos e integrado ao pensamento da mestiçagem como valor positivo.

O que nos parece interessante reforçar no nosso trabalho é que os movimentos ditos de trabalhadores ou de luta por melhores condições de vida na Bahia (aqui incluídas as iniciativas por educar-se) atingiam, no Pós-abolição e nos anos da Primeira República, a vida dos negros -

10 Cargo na hierarquia do Candomblé. 
denominados como "trabalhadores nacionais". E que são homens negros livres que participam e/ou disputam a sua direção. Embora não se tenha encontrado texto que explicitamente mostre um "pensamento negro", nos moldes do que acontece nos Estados Unidos, na Bahia da Primeira República, é ainda a partir de Manoel Querino que aparecem os primeiros escritos, datados dos anos 1915, 1916 que afirmam a presença africana/ negra entre nós como um fator positivo e, como ele assim diz, a sua importância na colonização do Brasil - colidindo frontalmente com a idéia da inferioridade da raça negra e da mestiçagem como fator de degenerescência. Seu debate é com o processo de exclusão, pela via do preconceito, do negro - ex-escravo - do mercado de trabalho e da cidadania. A afirmação da presença de elementos culturais africanos no Brasil, como demonstrativos do papel civilizador dos negros, coloca em pauta para discussão a possibilidade de mais de um padrão de civilização, num mundo em que se pretendia uma única via da civilização e em que os povos e suas visões de mundo estavam ordenados e hierarquizados a partir dela.

\section{REFERÊNCIAS}

A VOZ DO OPERÁRIO. Editorial. Salvador: Órgão Oficial do Centro Operário, v. 3, n. 28, 15 jun. 1897. Único exemplar existente no Arquivo Municipal de Salvador, Caixa Centro Operário.

ASSIS, Alberto. A instrução Primária na Bahia. Diário Oficial da Bahia, Edição Comemorativa do Centenário da Independência da Bahia, Salvador, 1923. p. 301-315.

BAHIA. Governo do Estado. Documentação Jurídica sobre o negro no Brasil: 1800-1888 (Índice Analítico). Secretaria de Cultura, Departamento de Bibliotecas. Salvador. Empresa Gráfica da Bahia, 1989.

BAHIA. Secretaria do Planejamento, Ciência e Tecnologia. Fundação de Pesquisas. A inserção da Bahia na evolução nacional. 1a etapa - 1850 1889. Salvador, 1978. 5 v.

BARBOSA, Rui. Reforma do ensino primário e várias instituições complementares da instrução pública. Salvador: Fundação Casa de Ruy Barbosa/Fundação Cultural do Estado da Bahia/Conselho Estadual de Cultura, 1982.

. A Reforma Eleitoral. In: Discursos Parlamentares, Brasília: Câmara dos Deputados, Gráfica do Congresso, 1985. 
- Parecer sobre o projeto n. 48 - Extinção do elemento servil. In: SENADO FEDERAL, 1823 a 1888 - 65 anos de lutas. Edição Comemorativa da Abolição da Escravidão. 1989. Brasília, Gráfica do Congresso.

BASTOS, Manuel Tranquillino. Minhas Percepções. Salvador, [193-?]. Não publicado.

CARONE, Edgar. A República Velha: instituições e classes sociais. São Paulo: Difusão Européia do Livro, 1972. p. 191-246.

CENTRO OPERÁRIO DA BAHIA, Constituição. Estado da Bahia. Bahia, Imprensa Econômica, 1896.

ClODOMIR, P. Manual Completo do Director de Música ou Tratado de Organização das Sociedades Musicaes Civis. Tradução de Manuel Tranquilino Bastos. Salvador. [193-?]. p. 6. Não publicado. xerox.

CUNHA, Luis Antonio. As raízes da escola de ofícios manufatureiros no Brasil: 1808/1920. Forum, Rio de Janeiro, v. 3, n. 2, p. 5-27, abr./jun. 1979.

GUIMARÃES, Antonio Sérgio. Manoel Querino e a construção do pensamento negro no Brasil entre 1890 e 1920. 2004. Disponível em: <http:www.fflch.usp.br/sociologia/asag/>. Acesso em: 10 dez. 2007.

HARDMAN, Francisco Foot. Cidades Errantes: Representações do trabalho urbano industrial nordestino do Século XIX. Ciências Sociais Hoje, São Paulo, 1988. Trabalho apresentado no GT Processo de Trabalho e Reivindicações Sociais. Anuário da ANPOCS, Ed. Vértice, 1988.

IBGE. Alguns resultados do Censo Demográfico de 1872 para a Província da Bahia. In: IBGE. Características Demográficas do Estado da Bahia: Edição Comemorativa do IV Centenário da Cidade do Salvador. Rio de Janeiro, 1949.

LEAL, Maria das Graças. Manoel Querino. Entre Letras e Lutas. Bahia: 1851-1923. 2004. 425 f. Tese (Doutorado em História Social) - Pontifícia Universidade Católica de São Paulo,São Paulo, 2004.

MATTA, Alfredo. Os Termos de Saída de Órfãos da Casa Pia: testemunho da transição da hegemonia do trabalho escravo para o assalariado na cidade de Salvador. In: MENEZES, Jaci et al. Educação na Bahia: memória, registros, testemunhos. Salvador: Editora UNEB, 2006.

MENEZES, Jaci. Educação e Cor-de-pele na Bahia - O acesso à educação de negros e mestiços. Bahia Análise e Dados. Salvador, v. 3, n. 4, p. 82-99, mar. 1994. Edição Especial sobre o Negro.

MENEZES, Jaci. Liberdade, Igualdade, Pluralismo e cidadania: o acesso à educação dos negros e mestiços na Bahia. 1997. 413 f. Tese (Doutorado em Ciências da Educação) - Universidade Católica de Córdoba, Argentina, 1997. xerox. 
MENEZES, Jaci. A Inclusão excludente: as exclusões assumidas. In: Educação e os afro-brasileiros: trajetórias, identidades e alternativas. Salvador: Novos Toques, 1997.

NINA RODRIGUES, Raymundo. Os africanos no Brasil. Brasília: INL/ UNB, 1988. (Coleção Temas Brasileiros n. 40)

QUERINO, Manoel. A raça africana e seus costumes. Salvador: Livraria Progresso Editora, 1955.

RAMOS, Jorge. Conservador Antenado. A Tarde, Salvador, 07 out. 2000. Cultural, p. 8.

SANTOS, Mário Augusto da Silva. A República do Povo: sobrevivência e tensões sociais. Salvador (1889-1930). Salvador: EDUFBA, 2001

SANTOS FILHO, Juvino Alves. Bandas, Filarmônicas e Mestres de Banda: formação de músicos e cidadãos. Revista da FAEEBA - Educação e Contemporaneidade, Salvador, v. 15, n. 25, p. 1-9, jan./jun., 2006.

SANTOS FILHO, Juvino Alves. Manuel Tranquillino Bastos: o mestre dos mestres de banda da Bahia. [s.l.]: Microservice, 2003. 1 CD-ROM.

. Manuel Tranquillino Bastos: estudo de duas obras para clarineta. 2003. 240 f. Tese (Doutorado em Música) - Universidade Federal da Bahia, 2003a.

. Manuel Tranquilino Bastos (1850-1935): mestre dos mestres de banda da Bahia. In: MENEZES, Jaci et al. Educação na Bahia: memória, registros, testemunhos. Salvador: EDUNEB, 2005. p. 243-250. 


\section{Saga nordestina: identidade(s) cultural(is) e exclusão social ${ }^{1}$}

Yara Dulce Bandeira de Ataide

Neste artigo, apresentaremos um olhar sobre a temática que denominamos de saga nordestina: identidade(s) cultural(ais) e exclusão social. Adotamos como explicação operacional para entendimento do conceito de identidade(s) cultural(is) esta afirmação de Hall (2005, p. 8): “São aspectos de nossas identidades que surgem de nosso 'pertencimento' a culturas étnicas, raciais, lingüísticas, religiosas e, acima de tudo, nacionais"

$\mathrm{O}$ artigo consta de três partes: na primeira, serão apresentados alguns aspectos da história oral de vida de duas colaboradoras de um projeto de nossa autoria, intitulado Clamor do Presente: história de famílias em busca da cidadania. A partir destes relatos, enfocaremos as questões relacionadas às suas origens, às autodefinições e, principalmente, aos assuntos ligados à nordestinidade.

$\mathrm{Na}$ segunda parte, pontuaremos alguns aspectos da questão das identidades no mundo atual. Na terceira, relacionaremos história de vida, identidade, unidade e diversidade cultural em referência à realidade nordestina. Tomamos como base da discussão explicações teóricas utilizadas por Michel Zaidan Filho nos seus estudos sobre $O$ fim do Nordeste e outros mitos (2001). Finalmente, levantaremos algumas conclusões.

Este artigo é uma adaptação da palestra proferida na sessão de encerramento do VI Encontro de História Oral do Nordeste:Temática, Memória(s) Cultura(s) e Nordeste (s), realizado em 05/05/2007, em Ilhéus - Bahia. 


\section{Histórias Orais DE VIDA}

As entrevistas que se seguem são parte de uma colônia da citada pesquisa. Foram transcritas, textualizadas e passaram por algumas correções lingüísticas para facilitar a leitura, tendo sido, porém, mantida a integridade das falas.

\section{"Se a colheita é boa, a gente vende tudo só pra pagar o banco e tá sempre na miséria..."}

Tenho seis filhos... Marido, eu não tenho mais... Nós chegamos aqui tem uns dez meses. Viemos de Pernambuco, fugindo da seca... procurando emprego. Naquele tempo, ele tava com a gente. Quando chegou aqui ele se ajuntou com uma turma de desempregados que saia prá procurar emprego.

Esse pessoal que se ajuntou com ele era gente muito ruim, braba... Depois que ele se ajuntou com esse povo de satanás, ele começou a xingar os meninos... A bater na gente... A fazer coisas ruins que ele não fazia antes... Uma noite, ele deixou a gente... Sumiu... Nunca mais tive notícia dele!...

Lá em Pernambuco, nós tínhamos uma casinha e um terreno, no interior, numa zona muito seca... A gente veio prá cá por causa da seca. Aqui, nem arranjamos canto pra morar, nem emprego... Agora, nem voltar mais a gente pode.

Lá na roça tinha uma escola... Nós andava muito prá chegar lá... Mais aprendeu pouco... Só sei assinar o nome... Era tudo difícil, naquele tempo....

Eu fico o dia todo aqui na rua, pedindo... Pedindo num canto, pedindo no outro... os meninos vão prá sinaleira... Eles limpa vidro... pede dinheiro... Eu fico por aqui, sentada, pedindo... Quando dá umas 4 horas os meninos voltam... Aí, a gente junta os dinheiros do dia, as coisas de comida que cada um conseguiu juntar... a gente vê o dinheiro que tem, o que pode comprar com ele... E vai cuidar de comprar o que comer...

Nós não temo nada.... Só uma duas camisas velhas, dois cobertores, uma panela e umas cinco colheres... Estas coisas a gente deixa guardada, perto da barraca de Sônia, aquela mulher morena daí... Quando fica de noite, a gente se junta e cata papelão e jornal, vai num canto desses, ou numa marquise, aqui perto. Todo dia é a mesma coisa... Uma luta prá comer e dormir....

Meus meninos, até agora, graças a Deus, não tem problemas com a polícia. Eu tô dominando eles direitinho e eles não fazem mal a ninguém, 
nem brigam com os outros... Na rua, o dia não é muito ruim, não... Mais de noite é um horror. Aparece muito maloqueiro querendo tomar nosso cobertor... Se a gente tiver alguma sacola de roupa ou comida, eles pegam... Eles vem e rouba a gente... A gente toma aquele susto, e ele sai correndo... Às vezes leva... Às vezes não leva nossas coisas...

Nossa vida é ruim demais... A gente fica todo dia pedindo... Não acha uma pessoa que dê uma ajuda... Queria tanto que alguém me ajudasse a fazer um barraco e arranjar uma creche prá os meninos .

Só aparece gente dizendo que vai levar os meninos pro juizado.

Se não fosse Deus, não sei o que seria da gente... Acho que é Ele que dá força à gente... se não fosse Ele, acho que todo mundo tava revoltado... Tem vez que a gente quer fazer uma besteira, mas se lembra de Deus e pede força a Ele prá vencer satanás e Deus dá esta força prá gente...

Você veja... Passa dias e dias... Não aparece coisa boa, nenhuma solução prá aflição da gente... Tem horas que fico pensando em acabar com tudo... Até com a vida...

O culpado da gente tá nessa situação é o prefeito... É o governador, que não ajuda o pessoal que carece de tudo... Eles só quer tudo prá eles... Mesmo rico, quer mais riqueza... Não dão uma força prá os pobres. A agente morava no sertão... Morria de trabalhar, se quisesse plantar um legume, ia pedir ajuda na prefeitura e eles não davam. A gente ia pró Banco, pedia um empréstimo... Quando tirava os legumes, o dinheiro ficava todinho na mão deles.

Às vezes não tem safra, não chove... Se a gente tiver uma coisa, uma criação, um boi, uma vaquinha, o banco toma, como tomaram da gente. Como a gente não pode pagar o empréstimo prá plantar, porque não teve inverno, a agente perdeu tudo... távamos devendo tanto, que tomaram tudo nosso e a gente ainda ficou devendo...

No interior, nunca ninguém vai prá frente... A gente morre de trabalhar... Quando produz o legume, vende tudo mais barato. Vem os carros da cidade comprar os legumes da gente por uma mincharia, e a gente tem que vender, porque, senão perde tudo. Nós temos que vender prá se alimentar porque tem vez que a gente tem feijão e arroz, mas precisa de café, de açúcar que a gente não tem, né?... E a roupa prá vestir, o remédio... Tudo que a gente tem, vende barato, e tudo que precisa comprar, compra muito caro...

Por que ninguém ajuda a gente, lá na roça?... É tudo na miséria, eles só querem explorar a gente... O povo peleja prá ir prá frente, mas só vai prá 
traz... A culpa é dos governadores... Dos presidentes, que não olham prá pobreza, por isso a pobreza tem que sofrer mesmo.

Eles não ajudam ninguém, não dão oportunidade prós pobres, só querem tudo prá eles... Por isso o pobre não vai prá frente... Não tem nada... Os ricos é que aumentam a miséria do mundo... O pessoal tá aí, se acabando de fome, precisando de ajuda, e ninguém olha a vida deles...

Muitos pobres tem que sair do lugar deles prá catar recursos, vai prá cidade comer lixo, pedir esmola, porque aqui aparece alguma coisa, e no interior tem que plantar e esperar que dê... e se não der, como é que o pobre fica?...

Lá no sertão, a gente trabalha no verão, vai aprontando a roça, e quando chega a chuva, a gente planta... Se não tiver semente, vai na prefeitura pedir... Ai, eles dizem que vão dar... Venha tal dia... Quando a pessoa volta, parece que tem um buraco no chão, porque a gente não vê o prefeito... Só vê aquela moça entrando e saindo...

Ela diz: ele chega já... Espere mais um pouco... Quando chega meiodia, a gente tá se acabando de fome, lá na porta da prefeitura... Mas não aparece ninguém... A $i$, as moças dizem:

- Ah!... O prefeito já veio e já foi embora... Ah!... Ele não veio hoje, não...

Parece que tem um buraco no chão... que ele entra e sai, e ninguém vê...

Tem vez que ele manda a gente ir ao Banco... Lá as pessoas tomam dinheiro emprestado... Aí, quando tem terra, eles faz o abate, mede as tarefas, vê quanto a gente vai receber. Eles arrumam o dinheiro prá comprar a semente prá gente plantar.... A gente planta... Quando não tem chuva, a plantação morre... Não tem colheita... A gente fica na miséria e devendo ao banco... Também, se a colheita é boa, a gente vende tudo só prá pagar o Banco, e tá sempre na miséria!... Não tem jeito, não, moça!...

Não confio nos políticos... Depois que eles ganharem, que tiverem mais ricos, aí é que vão pisar no pobre.

Vai ser sempre assim... No país, todo mundo tá se acabando... Daqui prá diante, ninguém vai esperar tempo bom, não... Nós já tamos no fim da era e já não tem mais bondade no mundo não... agora, só vai ter fome, peste, desgraça... mesmo prá quem tem riqueza... Eles não vão dá... Quem não tem, vai ter que morrer de fome, vendo tanta riqueza no mundo... Tem tanta coisa... A gente tem mesmo é que pedir, mesmo sabendo que ninguém 
dá... É por isso que tem muito roubo ai... Quem vê a riqueza dos outros, pede um pouquinho prá matar a fome, e não recebe nada, fica com raiva e vai roubar....

Como meu menino tava dizendo - tem dia que ele chega aqui chorando - vê uma pessoa comendo, vai pedir... Ta com fome, e o pessoal não dá... Enxota e humilha ele, dizendo:

- Vai trabalhar vagabundo, quem não trabalha, não come!...

- Trabalhar em quê ?...

- Cadê o trabalho?...

Trabalho prá menino não tem, não, senhora.

Nós não acha nada prá fazer. Sai nas casas pedindo trabalho, pedindo prá trabalhar, mas as pessoas têm medo da gente... Pensa que a gente é ladrão... Que vai roubar, porque muita gente ruim faz isso... Pensa que todo pobre é ladrão... Pensa que a gente vai fazer isso, também... Aí, como não acha trabalho, a gente tem que mendigar... Tem que pedir, mendigar o pão, até o dia que der... Esperar uma melhora...

A vida é tão dura que às vezes a gente tem vontade de fazer uma besteira... Assim... Dá vontade de pegar e roubar... Pegar os filhos da gente e dar todos e ficar sozinha no mundo.... Mas, depois eu penso que ainda tem Deus no mundo, tomando conta dos pobres, de nós todos, de todos aqueles que acreditam Nele e, aí, fico pedindo forças a Ele... O pobre, que tá na miséria, fica desesperado quando imagina que seu caso não tem solução... Quando pensa que não tem ajuda de ninguém, e não sabe o que pode fazer prá melhorar a vida...

Meus filhos são bons... Se não fossem eles, eu já tinha morrido, ou feito uma besteira... Mas, eu não posso fazer nada errado, por causa deles, né?... Tem vez que eu digo prá eles:

- Vou dá vocês!... Tem gente rica que passa aqui, e pede vocês prá criar... Eles olham prá mim, com medo, aí, eu digo prá eles:

- Vou dá vocês, sim!... Mas,eles choram e dizem:

- Ó, maínha, não quero morar com gente rica, quero ficar com a senhora... Prefiro ficar na rua sofrendo... Nós todos quer ficar juntos, na rua sofrendo, mais junto da senhora!.......

Falo assim, na hora do desespero, mas nunca vou ter coragem de largar meus filhos... Nem eles têm coragem de ir embora e me largar... 
Eu tenho uma menina, a Ana Paula... Uma mulher pelejou prá levar ela... Até deixei, mas ela disse que não ia... A mulher prometeu uma Barbie prá ela, disse que dava uma porção de coisas, e ela disse:

- Se quiser me ajudar, me leve junto com meus irmãos e minha mãe... Só quero ir se todo mundo for junto...

Essa mulher tinha uma casa muito bonita, com piscina, muito brinquedo, muita comida... Mas, ela preferiu ficar aqui, na miséria, sem nada, mais perto de mim.

Era bom se a gente tivesse tudo junto, e eu tivesse com meu marido... Já nem me lembro mais dele... Faz muito tempo que ele foi embora... Lá na roça, ele era bom... Trabalhava... Cuidava da gente... Quando chegou aqui, quando ficou sem emprego e se juntou com a turma de maloqueiros, começou a beber... A cachaça acabou com ele... Ele batia nos meninos e em mim, e não trazia nada prá nós... Passava um bocado de dias sumido e voltava sem nada... Tava sempre bêbado e brigando com a gente.

Eu tenho esperança em Deus, um dia eu saio da rua... Alguém vai me ajudar... Vai me dar um barraquinho... Aí, a gente sai da rua, de vez... Vamos vender ficha, vender qualquer coisa prá arrumar uns trocados... Ficamos na rua direto, trabalhando, pedindo... Mas, de noite vou ter meu ranchinho prá morar, uma escola prá botar os meninos prá estudar... E, assim a gente vai levar a vida.... Quando os meninos for prá escola eles vão ficar sabidos e depois vão achar trabalho... Só estudei um pouco na escola da roça, mas acho que a escola ajuda as pessoas a ficar sabida... Se eu tivesse estudado não tava aqui...

Tenho fé que eu vou conseguir, nem que seja uns pedaços de madeira e uma lona... Se eu tiver uma lona, finco quatro paus no chão, boto minha lona em cima e fico lá... Me prometeram que, no Natal, vão me dar a lona... A madeira a gente arranja... Com ajuda de Deus a gente consegue...

- Deus é bom, né, moça?.. Ele já ajudou a senhora alguma vez?...

Neide, 32 anos, parda.

\section{"A criança nasceu morta e eu fiquei arrebentada..."}

Ah! minha filha!... A gente morava em Mata de São João. Lá, José trabalhava e eu também... Mais veio a doença... Eu era doméstica, 
trabalhava muito e já tinha quatro filhos grandes... O José trabalhava pros outros... Um dia, caiu de um andaime...

Naquele tempo os meninos mais grandes se espalharam... Foram trabalhar nas casas e José, meu marido, Zinho e eu ficamos numa casinha que nós alugava... Todos dois doentes!...

Um dia, o Zinho pediu ao prefeito umas passagens pra trazer nós aqui prá Salvador... Queria botar nois no hospital e arranjar emprego...

Chegamos na rodoviária e o Zinho levou nós pró Hospital de Irmã Dulce... passamos o dia todo na porta, dormimos lá... Depois de uns dois dias conseguimos ir pro médico. Ele me internou uns dias e foi muito bom com nós... Mais não quis internar o José. Disse que não precisava e passou remédio pra ele...

O José e o Zinho não tinham lugar pra ficar... Se arranjaram num cantinho perto do hospital e ficaram penando na rua... Quando o doutor me deu alta tive que ir pra rua também... Era carregada nos braços... Não me mexia sozinha...

Foi um horror viver na rua!... Até sede nós passamos e o Zinho não podia trabalhar, só pedia comida e água e cuidava de nós... Passamos um bocado de tempo no Bonfim, mais depois prometeram ajudar a gente... Um homem da prefeitura... Mas ele não voltou mais...

Paramos uns tempos lá e fomos indo de um lugar pra outro até chegar aqui na Piedade...

Nesta rua, o povo não tem nem dó de nós... Vai pra lá e pra cá... E num quer saber se a gente tá vivo ou morto... Só um pingo de gente olha pra nós e dá uns trocados... E tem pena de nós e dá umas roupinhas, um cobertor...

Minha filha, nem sei mais como era minha família em Mata... Quando os meninos eram pequenos e nós trabalhava, tudo era bom... A gente tinha família e tinha casa, comida e parentes... Nós agora somos só uns esmolés, umas porcarias, sofrendo na rua...

Eu só quero que Deus me ajude a morrer em paz antes de José e do Zinho...

Meus outros filhos não existem mais, se não fosse o Zinho... Tava tudo acabado...

Quando nós tem o que comer, nós faz um fogo e pega uma lata pra cozinhar a comida... Eu ainda sei fazer umas gororobas ${ }^{2} .$.

\footnotetext{
${ }^{2}$ Gororobas gíria que significa comida popular, misturada, um arranjo.
} 
Nós só tem Deus por nós... Se Ele não ajudasse os pobres tudo tava acabado.

O trem mais ruim daqui é o frio de noite e a fome... Quase todo dia...

Não sei ler, não sei escrever e penso que votar não adianta nada... Os ricos tão lá e os pobres aqui se acabando... Nunca fui pra escola... Meu pai não queria... Dizia que pobre não precisa de escola...

Não espero mais nada da vida (chorou muito neste momento da entrevista...)

Só queria ter um cantinho pra ficar em paz até morrer e queria muito, muito, que meu filho arranjasse um emprego...

Maria de Lourdes, 56 anos, negra.

\section{Auto-Identidades E IDENTIDADES Atribuídas}

Estes dois depoimentos apresentam narrativas sobre aspectos da cultura, das vivências e valores de duas mulheres nordestinas e serão utilizados para o estabelecimento de relação com as questões teóricas que pretendemos apresentar.

Faremos uma indagação inicial. Há, de fato, uma identidade nordestina?

Quem se considera nordestino/a ou se auto-define como tal nos nossos dias? Como sabemos, as auto-identificações são, em muitos casos, racionalizações, posicionamentos pessoais e explicitações a partir da construção de sua biografia e do reconhecimento de seus valores, sua rede de relações e seu lugar social. Em muitas outras situações, relacionadas, principalmente às classes populares e aos grupos excluídos; essas identidades são externamente atribuídas e ganham conotação pejorativa, transformandose em verdadeiros estigmas que o outro impõe a determinados grupos minoritários. E entre estes estereótipos está a identidade nordestina.

Alguns historiadores atribuem a Gilberto Freire uma das mais duradouras produções discursivas da cultura brasileira do século XX: a chamada brasilidade nordestina. Como afirma Zaidan Filho (2001, p. 11):

[...] a engenhosa combinação feita pelo mestre entre modernismo e regionalismo, mitigando os efeitos choquiformes (urbano-industriais) da estética modernista e dando lugar ao ciclo da cultura regionalista da década de 1930 (José Américo, Rachel de Queiroz, José Lins do Rego e outros) e a fetichização dos traços 
culturais nordestinos (a cocada, o bolo de Sousa Leão, o açúcar, a arquitetura, os costumes sexuais, as crendices religiosas etc) apresentados como "vantagens comparativas" civilizatórias de nossa raça no concerto das outras nações... [...] ... esta operação festejada nacional e internacionalmente como marca da originalidade brasileira: é ao mesmo tempo o reforço, a justificativa (para não dizer a racionalização) de aspectos conservadores, oligárquicos e tradicionalista de nossa sociedade. A consequiência disso é a estetização do nosso atraso (vide a dialética do picaresco e da malandragem na obra de Antonio Cândido e Roberto Schawarz) permite mil e uma utilidades da obra freyriana: da sua utilização pelos grupos de direita para produção de consenso e unidade nacional até sua adaptação como entretenimento de massa pela industria cultural moderna (ZAIDAN FILHO, p. 12-13).

O projeto ideológico que animou esse historicismo idílico foi o movimento regionalista do inicio do século XX (1920) este fez frente à luta pela redefinição do Estado Nacional que contribuiu para reduzir o poder político das oligarquias. Essa proposta, alimentada por intelectuais e romancistas, teve o mérito de "conferir uma sobrevida simbólica, estética e cultural a essa oligarquia decadente" (ZAIDAN FILHO, 2001, p. 22).

Compõe a citada política cultural, um tipo humano com traços psicológicos como solidão, solidariedade, fatalismo, tradicionalismo e, também, ligação com a terra de origem, pouca escolaridade e cultura rural. Complementando este "passado idílico", romanceiam-se as relações sociais, a cordialidade senhor-escravo e destaca-se o paternalismo oligárquico como protetor e provedor: é como se fora vocação do nordeste ser um celeiro de pobres e serem mantidos pelos ricos e pelo Estado.

Ainda Zaidan, no seu pequeno grande livro O fim do Nordeste e outros mitos, discute uma segunda tendência de explicação que difere desse culturalismo e constitui-se como uma posição estética realista ou neorealista que busca retratar a identidade nordestina como nominativo de uma humanidade ferida e extremamente empobrecida pela seca, analfabetismo, condições econômicas e vítima das oligarquias e do latifúndio.

Este segundo movimento explicativo da questão mostra, com realismo e espírito analítico, um discurso critico e reflexivo que procura desnaturalizar a questão através da denúncia dos problemas sociais e humanos e enunciar sua superação através de políticas públicas e transformação social. São apontados como representantes dessa discussão Graciliano Ramos, João Cabral de Melo Neto e vários outros(as) intelectuais e letrados(as). 
Dentro dessa grande discussão da(s) identidade(s) nordestina(s) - e sua fonte, a cultura popular do Nordeste - há, ainda a considerar uma terceira vertente, que toma como marco fundante a cultura da exclusão social,na qual o nordeste seria o celeiro da neomiséria e dos excluídos sociais do Brasil pós-moderno. Constituído por grupos humanos pobres, pouco escolarizados e migrantes de diversas áreas em busca de melhores condições de vida que terminam por aumentar a população e os problemas das periferias das grandes cidades ou tornam-se moradores de rua. Muitas vezes, o ciclo da pobreza e do desamparo permanente transforma esses migrantes e seus descendentes em frutos da cultura urbana, agressiva e violenta. Assim, eles são levados a perder o perfil romântico e rural e a se tornarem refratários à sociabilidade.

Estes homens e mulheres estão imersos nas periferias urbanas e numa cultura da violência, caótica e heterogênea advindas de diversas matrizes etno-culturais e que representam os processos de exclusão e discriminação existentes nos nossos dias. A naturalização dessas construções identitárias, com seus traços e princípios conservadores, predispõem os(as) nordestinos(as) a aceitarem o substrato social descrito por Gilberto Freire e seus ideólogos.

Colocando esta discussão no contexto da questão contemporânea e globalizada, observamos que a temática da identidade é uma das mais importantes e que ocupa o centro de todas as atenções.

Para Hall as sociedades pós-modernas estão sofrendo um processo de mudanças estruturais que tem gerado instabilidade e fragmentado paisagens culturais de classe, gênero, raça e nacionalidade e outras referências que tenham gerado um padrão estável para nossas identidades pessoais e de sujeitos integrados. Estes inúmeros processos de mudanças geram instabilidades para as identidades dos sujeitos nas esferas social e cultural, provocando a perda de sentido de si.

A identidade plenamente unificada, completa, segura e coerente é uma fantasia. Ao invés disso, à medida em que os sistemas de significação e representação cultural se multiplicam, somos confrontados por uma multiplicidade desconcertante e cambiante de identidades possíveis [...] (HALL, 2005, p.13).

Quando da proposta freiriana da construção do conceito de região e identidade nordestinas houve toda uma produção cultural impulsionada pelo "mandarinato literário" que, no dizer de Zaidan (2001, p. 50), vão 
dar-lhe força estética, simbólica e cultural. É uma primeira fase onde poetas e escritores, como Manoel Bandeira, Cícero Dias e Vicente do Rego Monteiro, deram grande contribuição.

Entretanto, à proporção que se consolida na segunda metade do século XX, a chamada globalização - com o seu séqüito de grandes mudanças sociais e econômicas - reduz-se a importância das macro-identidades regionais. Isto porque as tradicionais identidades nacionais e regionais perdem sua força para as múltiplas, descentradas e fluidas identidades pósmodernas. Identidades estas que, como afirma Bhabha (2005, p. 20) nos levam a:

uma existência marcada por uma tenebrosa sensação de sobrevivência, de viver nas fronteiras do presente, para as quais não parece haver nome próprio além do atual e controvertido deslizamento do prefixo pós: pós-modernismo, póscolonialismo, pós-feminismo[...].

Há, de um lado, muitas possibilidades de identificação do sujeito a grupos múltiplos que, embora, fluidos ou fechados e exigentes lhe permite afinizar-se e sentir-se em sintonia com as comunidades de identidade profissional, religiosa, étnica, de gênero entre outras. Para Bauman,

[...] devemos levar em consideração 'as comunidades virtuais' [...] 'onde' é fácil entrar e ser abandonado [...] quando a identidade perde as âncoras sociais que a faziam parecer 'natural', predeterminada e inegociável, a 'identificação' se torna cada vez mais importante para os indivíduos que buscam desesperadamente um 'nós' a que possam pedir acesso (2005a, p. 30).

Nessa conjuntura atual, podemos falar da relação existente entre estratificação social, educação, poder político e econômico e possibilidades de identificação. Na modernidade líquida definida por Bauman (2005b, p. 44), há uma hierarquia que se inicia com os sujeitos sociais emergentes, participantes de vários grupos culturais, com poder econômico e político que podem escolher e identificar-se com inúmeros grupos ou comunidades. Estes assumem ou descartam identidades rapidamente e, de forma planetária, tendo livre acesso aos benefícios enquanto perdura seu poder de troca.

Este universo complexo e exigente com todo um conjunto de opções finaliza sua oferta num outro extremo onde se encontram os desventurados. Aquele grande contingente humano que não tem direito a escolha de sua (s) identidade(s). Estes excluídos sociais - econômicos e/ou políticos - não 
possuem a possibilidade de assumirem identidades à sua própria escolha, por isso, recebem de outros grupos identidades que os estigmatizam e desumanizam. O mais dramático é que, nessa posição, não há vontade individual que consiga superar seu estereotipo. "Você é excluído do espaço social em que as identidades são buscadas, escolhidas construídas [...]" (BAUMAN, 2005b, p. 46).

Estamos, portanto, numa encruzilhada sócio-político-econômica na qual ou nos tornamos cidadãos do mundo, com toda uma grande bagagem educacional, profissional, econômica e cultural ou somos excluídos do mercado e teremos cerceadas nossas oportunidades sociais, nossa autonomia, nossa cidadania e nossa(s) própria(s) identidade(s).

\section{IDENTIDADE X NORDESTINIDADE}

Integrando algumas dessas considerações de estudiosos da contemporaneidade com as histórias de vida das nossas colaboradoras e, com nossas próprias trajetórias de nordestina(s) e nordestino(s) podemos realizar algumas reflexões.

A identidade regional concebida como nordestina surge de uma ideologia conservadora a partir de interesses das classes dominantes que procuram envolver o povo transformando alguns dos seus costumes e valores em fatores de unidade e identificação. Há uma mitificação de patrimônios culturais materiais e imateriais que romantizam e camuflam relações sociais assimétricas e preconceituosas.

Inicialmente a identidade nordestina - como a nacional - era uma macroidentidade que homogeneizava as identidades étnico-culturais de grupos e comunidades rurais e urbanas diferentes. Entre as formas de uso inadequado da mesma está a manipulação política eleitoreira para gerar consensos e lealdades. Há, também, a transformação da seca num mito em torno do qual a elite cria e recria explicações e soluções esotéricas e enganosas.

O tipo humano que representa o nordestino e a nordestina no imaginário social e na cultura de massa são o homem e a mulher sertaneja, pobres de pouca ou nenhuma instrução, ingênuos, migrantes, moradores na periferia, operários ou desempregados e moradores de rua que integram a falange dos "neo-miseráveis". 
Se considerarmos o primeiro período de disseminação da ideologia da nordestinidade, em muitos momentos encontramos as classes mais aquinhoadas e os intelectuais da região se auto-afirmando nordestinos.

Mas, considerando-se esta fase atual - talvez os últimos trinta anos esta identidade tornou-se um estigma, atribuído aos excluídos, quando nordestinos e nordestinas tornaram-se denominações para designar migrantes da região geopolítica do mesmo nome, que em São Paulo e outros estados, mesmo do nordeste, dedicam-se a tarefas mais simples e menos valorizadas ou definham e se desesperam na cova rasa do desemprego.

Já as classes nordestinas socialmente mais privilegiadas, constituídas por universitários, profissionais qualificados, políticos, entre outras, manipulam esta e outras identidades, usando-as segundo as conveniências e encobrindo-as ou mesmo negando-as segundo seus próprios interesses.

A expressão "modernidade líquida", de Baumam, explica bem, na atualidade do início de século XXI, que é crucial analisar e mesmo debruçarse sobre esta questão com um novo olhar, partindo-se do princípio que a transitoriedade da sociedade atual impõe. É preciso que se considerem muito mais as infinitas faces do movimento e do transitório que atinge desde a esfera econômica à afetiva, sobrepondo-se à permanência que as antigas noções de perenidade e identidades fixas e inegociáveis oferecem.

Esta voragem incessante e angustiante, que atinge todos e até os relacionamentos amorosos, continua produzindo excluídos em número cada vez maior, que vão integrar o contingente dos despossuídos, constituído por quase um bilhão (985 milhões) de "vidas desperdiçadas", que vivem na periferia do mundo globalizado.

Bauman, explicando essa conjuntura, dramaticamente vaticina:

Feridos pela experiência do abandono, homens e mulheres desta nossa época suspeitam ser peões no jogo de alguém, desprotegidos dos movimentos feitos pelos grandes jogadores e facilmente renegados e destinados à pilha de lixo quando eles acharem que eles (os peões) não dão mais lucro (BAUMAN, 2005b, p. 53).

\section{(IN)CONCLUSÕES}

Que relações podemos estabelecer entre a(s) história(s) de vida que apresentamos de nordestinas das classes populares e essas questões abordadas inerentes à contemporaneidade envolvendo um grande e diverso 
conjunto de pessoas habitando localidades diferentes, com trajetórias diferenciadas de vida, culturas e aspirações diferentes? Elas, por serem excluídas não são beneficiadas por mudanças sociais, educacionais, econômicas e políticas, capazes de lhe conferirem possibilidades de superar as limitações atuais para se inserirem na torrente global, ainda que também perigosa e excludente.

É o caso da nossa entrevistada Neide, que na sua comunidade do interior pernambucano fazia parte de uma família de pequenos proprietários e acabou por perder sua propriedade, seu marido e tornar-se moradora de rua em Salvador.

"Lá em Pernambuco, nós temos uma casinha e um terreno, no interior, numa zona muito seca... [...] Aqui, nem arranjamos canto pra morar, nem emprego [...](Neide)". Ela representa um grupo familiar desenraizado, absolutamente excluído de sua rede de relações locais e do contexto urbano atual onde se sente expropriada em todas as instâncias pessoais e sociais.

Revendo um trecho da outra história de vida de nossa entrevistada, Maria de Lourdes, onde ela nos fala sobre sua família e mostra sofrimento e impotência diante da inexorável realidade:

[...] Em Mata de São João. quando os meninos eram pequenos e nós trabalhava, tudo era bom... tinha família, tinha casa, comida e parentes... nós agora somos só uns "esmolés"... umas porcarias, sofrendo na rua...

Não sei se podemos ou não falar do fim da identidade nordestina ou das múltiplas nordestinidades, mas, certamente, ela vai de encontro às tendências do mercado competitivo e da globalização excludente.

Existe uma exacerbada competição entre estados da região estes, priorizando as atividades econômicas, tais como turismo, agricultura irrigada para exportação e outras atividades para as quais existem políticas de atração de investimentos diretos estes estimulam aguerrida concorrência que gera o "fenômeno de hobbesianismo estadual", em detrimento da colaboração e solidariedade tão necessárias e desejáveis porque o que se vê é a fragmentação econômico-social da região.

Mas, se pensarmos e lutarmos com otimismo por uma nova sociedade e uma outra globalização, como propõe nosso grande geógrafo e pensador Milton Santos, certamente que será possível resgatar esta identidade com mais espírito critico, depurando-a de seus erros de origem. É fundamental 
valorizar a diversidade cultural regional como esfera agregadora e espaço de discussão e ação, fortalecendo autonomias e incluindo as culturas e cidadanias locais no mundo global. E, nesse contexto, as outras instâncias das identidades regionais, entre outras, serão apenas outros espaços.

Para Zaidan Filho, grande estudioso da região:

O desafio que o terceiro milênio reserva para o nordeste é convencer as elites econômicas e dirigentes do país de que é possível se integrar na economia mundial sem abandonar seus pobres e miseráveis. E que o principal ativo de uma nação é seu povo e suas tradições culturais.

Paises sem política de desenvolvimento regional e social e sem identidade estão destinados a ser meras plataformas de exportação para o mundo, sem cidadãos, direitos e identidade cultural (2001, p. 52-53).

Educação, empregos e políticas públicas competentes e responsáveis, poderão contribuir decisivamente para que a população nordestina revise sua identidade e assuma as rédeas de seu próprio destino, superando a dependência e exclusão social.

\section{REFERÊNCIAS}

ANDRADE, Manuel Correia de. A seca: realidade e mito. Pernambuco: Ed. Asa, 1985.

BHABHA, Homi K. O local da cultura. Belo Horizonte: Ed. UFMG, 1998 BAUMAN, Zygmunt. Vidas desperdiçadas. Tradução: Carlos Alberto Medeiros. Rio de Janeiro: Jorge Zahar Ed. 2005a.

. Identidade: entrevista a Benedetto Vecchi. Tradução: Carlos Alberto Medeiros. Rio de Janeiro: Jorge Zahar Ed, 2005b.

HALL, Stuart, A identidade cultural na pós-modernidade. 10. ed. Tradução: Tomaz Tadeu da Silva e Guaracira L. Louro. Rio de Janeiro: DP \& A, 2005.

SANTOS, Milton. Por uma outra globalização: do pensamento único à consciência universal. 6. ed. Rio de Janeiro: Record, 2001.

ZAIDAN FILHO, Michel. O fim do nordeste e outros mitos. São Paulo: Cortez, 2001. 



\title{
(Auto)biografia, histórias de vida e práticas de formação ${ }^{1}$
}

\author{
Elizeu Clementino de Souza
}

\begin{abstract}
A discussão sobre Pesquisa Autobiografia, Histórias de vida e História da Educação tem possibilitado ampliar as questões teórico-metodológicas e, especialmente as relacionadas a produção, visibilidade de outras fontes e perspectivas de pesquisas, por entender que, conforme afirmam Souza e Menezes,

No âmbito da História da Educação e de outros campos do conhecimento educacional, as pesquisas com fontes menos tradicionais e mais recorrentes começam a ter e adquirir novo estatuto metodológico e apresentam novos esforços para uma compreensão das práticas educativas e escolares (2006, p. 146).
\end{abstract}

Isto me leva a refletir sobre como o trabalho com certas fontes aparece acompanhado pelo debate sobre a própria produção da fonte. A emergência de outras fontes menos recorrentes se inscreve, numa perspectiva da história cultural e da história social, marcando a crescente utilização de diferentes fontes em pesquisas acerca da imprensa pedagógica; dos manuais escolares, dos programas de ensino, dos currículos e conteúdos de exames, etc. Tais fontes são as autobiografias, as memórias, as histórias de vida, as narrativas escritas, a literatura, as fontes iconográficas, midiáticas e os programas televisivos.

\footnotetext{
O presente artigo foi apresentado na Mesa Autobiografia na História da Educação, no âmbito do II Encontro Norte - Nordeste de História da Educação e I Encontro Maranhense de História da Educação, realizado entre os dias 20 a 23 de agosto de 2007. Compuseram a referida mesa Elizeu Clementino de Souza - UNEB, José Gerardo Vasconcelos - UFC e Marlucia Paiva - UFRN. Ao tomar As questões de método na Pesquisa em História da Educação' como temática central, o ll Encontro Norte-Nordeste de História da Educação e I Encontro Maranhense de História da Educação buscam aprofundar discussões sobre questões vinculadas às fontes, procedimentos de recolha, análise e interpretação na pesquisa histórica, ao confirmar a relevância e o significado da temática para o campo das pesquisas em história da educação nessas regiões do Brasil.
} 
A intenção neste trabalho é discutir sobre as aproximações e possíveis distanciamentos entre as (auto)biografias, a história da educação e as práticas de formação, por entender como afirma Catani $(2005$, p. 32) que, "as escritas das obras autobiográficas que testemunham as relações pessoais com a escola pode ser útil como fonte para a elaboração da história da educação", ao traduzir sentimentos, representações e significados individuais das memórias, histórias e relações sociais com a escola.

Conforme Souza, Sousa e Catani (2007), o movimento biográfico no Brasil tem sua vinculação com as pesquisas na área educacional, seja no âmbito da História da Educação, da Didática e Formação de Professores, bem como em outras áreas que tomam as narrativas como perspectiva de pesquisa e de formação.

A criação e atuação do Grupo de Estudos Docência, Memória e Gênero (GEDOMGE-FEUSP) marcam as primeiras experiências com pesquisas (auto) biografias como práticas de formação, através das aproximações das memórias e trajetórias de professoras com seus percursos e aprendizagens da docência, entrecruzando com questões de gênero. $O$ trabalho de Bueno, Sousa, Catani e Chamlian (2006) sistematiza o percurso do grupo, destacando pesquisas realizadas, experiências desenvolvidas com projetos de formação de professores em serviço com base nas histórias de vida como perspectiva de formação e auto-formação. Cabe destaque a realização do $1^{\circ}$ Seminário Memória, Docência e Gênero, cuja intenção foi de reunir pesquisadores e conhecer investigações desenvolvidas no âmbito das histórias de vida e suas relações com a formação, trabalho docente e identidade profissional, o que se configura como uma das primeiras possibilidades de aglutinação e mapeamento de pesquisas com as histórias de vida na educação brasileira, no campo da formação de professores.

As duas primeiras edições do Congresso Internacional sobre Pesquisa (Auto)Biográfica, em Porto Alegre (I CIPA, 2004) e em Salvador (II CIPA, 2006), configuram-se como momentos significativos para o campo dos estudos biográficos no Brasil, tendo em vista a sistematização das peculiaridades das produções, modalidades de trabalho, configuração dos espaços acadêmicos de onde emergem e se consolidam tais estudos, diversidade de pesquisas que se apropriam das autobiografias como prática de formação no território da formação continuada de professores, estudos no âmbito da história da educação e das práticas de formação e, por fim, 
a re-invenção de modos de trabalho ancorados em uma base teórica, cujos autores apresentam diferentes práticas de pesquisa com histórias de vida.

As pesquisas desenvolvidas na pós-graduação em educação no Brasil e a criação de diferentes grupos de pesquisas (SOUZA, 2006) contribuíram para a ampliação das pesquisas com as histórias de vida e (auto)biografias na área educacional, seja como prática de formação, seja como investigação ou investigação-formação. Essas questões nos remetem a entender que a diversidade de produção característica no Brasil sofre influência teórica e metodológica de diferentes disciplinas e áreas do conhecimento.

Ao examinar a diversificação das entradas e terminologia das pesquisas Pineau (2006, p. 41), afirma que "a flutuação terminológica em torno das histórias e relatos de vida, biografias e autobiografias é indicativa da flutuação do sentido atribuído a essas tentativas de expressão da temporalidade vivida pessoalmente". Destaca também as possibilidades de experiências na educação e na formação de adultos, ao buscar ampliar a discussão epistemológica e um panorama histórico, numa dialética ascendente/descendente entre os discursos e os percursos de vida, articulando o bio-questionamento à expansão das artes de existência.

As questões inicialmente apresentadas possibilitam ampliar e discutir a relação memória, narrativa, (auto)biografia e história da educação, ao tomar como referência para organização do presente texto os trabalhos de Souza (2006, 2004 e 2003), Souza e Abrahão (2006), Souza e Fornari (2005), que sistematizam reflexões teórico-metodológicas sobre as histórias de vida em formação e a fertilidade da utilização do trabalho centrado na memória e na abordagem biográfica na formação de professores e no campo do estágio supervisionado.

MEMÓRIA, NARRATIVA E (AUTO)BIOGRAFIA: PRODUÇÃo DE SENTIDOS E A CONSTITUIÇÃO DO CAMPO ${ }^{2}$

Quais foram as circunstâncias que possibilitaram a utilização da memória e da narrativa como fontes críveis de produção de conhecimento, inclusive, de um conhecimento com potencialidade formativa? A valorização dessas

As discussões aqui apresentadas foram sistematizadas por Souza e Fornari (2005), no âmbito da Pesquisa Memórias do Colégio Nossa Senhora do Carmo: imagens e representações de ex-normalistas na/sobre a formação docente (1950-1960). 
fontes ocorreu no bojo da alteração paradigmática produzida a partir das dúvidas levantadas sobre a capacidade, do conjunto de referências teóricas e metodológicas das ciências naturais, de dar conta da compreensão dos fenômemos sociais. Problematizou-se, então, a noção de cientificidade a partir da contestação do positivismo que, até então, constituía-se como idéia reguladora hegemônica na produção do conhecimento válido. Concordamos com Najmanovich (2001, p. 35), quando afirma que:

O que a epistemologia clássica chamava de 'conhecimento objetivo' nada mais é que o produto de um processo histórico de padronização perceptual e cognitiva que culmina com a naturalização. As categorias se naturalizam graças à estabilização dos modos de representação.

É, portanto, da contestação do positivismo que emergem as possibilidades de um novo paradigma compreensivo. Temos que perceber a alteração do real produzida pelas ações concretas dos atores sociais, que reivindicam métodos próprios para tratar o conhecimento no âmbito das ciências do humano. Josso (2004, p. 20) lembra-nos que a reabilitação epistemológica do sujeito e do ator "pode ser interpretada como um retorno do pêndulo depois da hegemonia do modelo de causalidade determinista das concepções funcionalistas, marxistas e estruturalistas do indivíduo, que dominaram até o final dos anos setenta".

No campo da produção historiográfica, a Nova História surgida na França, disposta a defender uma mudança metodológica na pesquisa e tendo por base três bandeiras - "novos problemas", "novas abordagens" e "novos objetos" - , amplia a noção de documento histórico reconhecendo a importância das fontes orais. No âmbito desse movimento mais amplo está a Escola dos Annales, movimento que reúne historiadores em torno da edição da revista dos Annales, intitulada originalmente Annales: économies, societés, civilisations. Segundo Rocha (2003), é na historiografia francesa que se encontra o marco teórico decisivo para a contestação da historiografia tradicional. No processo de valorização das fontes orais estava a crença de que a maior homenagem que os historiadores e, em especial, os historiadores da educação, poderiam prestar aos excluídos era o de transformar suas memórias em história, buscando memórias sociais que recuperassem os sentidos das vozes ausentes.

Um dado importante deste contexto é compreender como o desenvolvimento tecnológico contribuiu para certa objetivação do relato 
oral, a partir da descoberta da tecnologia do gravador e das fitas magnéticas, por volta da década de 40 do século XX. O gravador possibilitou que as memórias fossem registradas em suportes materiais, o que permitiu o acesso para além do momento de sua coleta. Hoje, a preocupação é com a sistematização de arquivos sonoros, o que pode ser atestado nos currículo de faculdades de Biblioteconomia e Arquivística, nos quais há disciplinas que abordam questões relativas à documentação audiovisual. Após esse breve registro do papel da técnica para o desenvolvimento da história oral, é importante reconhecer que a força dessa História está em sua pretensão de dar a voz àqueles que não a tem, questionando as narrativas dominantes da historiografia tradicional. O reconhecimento da legitimidade dessas fontes para a pesquisa em História permitiu que vozes, até então silenciadas pela História tradicional, reivindicassem o direito de falar, o que expôs o fato de que a História é, também, um campo de tensão e disputa. Assim os negros, as mulheres, os índios, os homossexuais vão buscar na indagação do passado, a partir de suas memórias individuais e coletivas, as circunstâncias sociais e culturais que os conformaram no tempo presente e que permitem pensar em projetos para o futuro.

Quando invocamos a memória, sabemos que ela é algo que não se fixa apenas no campo subjetivo, já que toda vivência, ainda que singular e auto-referente, situa-se também num contexto histórico e cultural. A memória é uma experiência histórica indissociável das experiências peculiares de cada indivíduo e de cada cultura. Conforme lembra-nos Bosi (2003), existe um substrato social da memória articulada com a cultura, tomada em toda sua diversidade estética, política, econômica e social.

O paradigma hermenêutico, no qual a abordagem compreensiva se insere, destaca a importância do sujeito no seu papel de intérprete, onde a memória tem uma importância fundamental. A lembrança remete o sujeito a observarse numa dimensão genealógica, como um processo de recuperação do eu, e, a memória narrativa, como virada significante, marca um olhar sobre si em diferentes tempos e espaços, os quais se articulam com as lembranças e as possibilidades de narrar experiências. Do ponto de vista gnosiológico, a hermenêutica fenomenológica busca compreender os sentidos de determinados fenômenos elaborados pelo sujeito, sendo que, nesses termos, a rememoração é sempre reflexão e auto-reflexão. Trabalhar com a memória, seja a memória institucional ou a do sujeito, faz emergir a necessidade de 
se construir um olhar retrospectivo e prospectivo no tempo e sobre o tempo reconstituído como possibilidade de investigação e de formação de professores. A memória é escrita num tempo, um tempo que permite deslocamento sobre as experiências. Tempo e memória que possibilitam conexões com as lembranças e os esquecimentos de si, dos lugares, das pessoas, da família, da escola e das dimensões existenciais do sujeito narrador.

No que se refere à relação memória e esquecimento, Augé (1998) indica pistas para entender que as mesmas são solidárias e vinculadas ao tempo presente. O esquecimento nos remete ao presente, mesmo que seja para viver em outra dimensão as experiências circunscritas de nossa vida. Afirma o autor que: "É preciso esquecer para continuar presente, esquecer para não morrer, esquecer para permanecer fiel" (1998, p. 106). Corroboramos com a idéia do referido autor, quando entendemos que o conceito de esquecimento como ausência de recordação ganha outro significado, quando o vê como um componente indissociável da memória, visto que "O esquecimento, em suma, é a força viva da memória e a recordação o seu produto" (AUGÉ, 1998, p. 27). Essa compreensão da memória e do esquecimento somente pôde surgir na órbita de uma epistemologia que construiu novas sensibilidades. Somos herdeiros/as de uma epistemologia moderna que buscou na distinção clara entre sujeito-objeto, no calar da subjetividade, o caminho para construir o conhecimento objetivo. Evidentemente que nossa proposta epistemológica e metodológica situa-se numa perspectiva crítica à epistemologia moderna. Nossa crença não é a de que a descorporificação do conhecimento garanta rigor e imparcialidade, já que os corpos, as memórias e as intencionalidades estão, dialeticamente, situados em determinado espaço/ tempo. Portanto, do ponto de vista epistemológico, acreditamos que toda cosmo visão está relacionada com uma moldura teórica que a condiciona e enfoca, ou seja, "vemos unicamente na zona do espectro a que somos sensíveis e vemos de maneira diferente segundo a iluminação e a nossa sensibilidade" (NAJMANOVICH, 2001, p. 25). Complementando a fala da autora podemos afirmar que vemos e rememoramos a partir de nossas referências e de nossas sensibilidades.

A principal implicação do paradigma hermenêutico/compreensivo para a produção de conhecimento é a emergência de uma concepção científica mais acessível à pluralidade do saber humano, ao mesmo tempo em que reconhece a perspectiva da complexidade como estruturante da 
existência do ser no mundo. Nestes termos, a memória aparece como elemento fundamental na articulação de sentidos entre o individual e o coletivo.

\section{HistÓRIAS DE VIDA: PERSPECTIVAS METODOLÓGICAS}

É no bojo do paradigma compreensivo, que a história de vida se legitima como método/técnica de investigação/formação, situando-se no campo da virada hermenêutica, em que se compreendem os fenômenos sociais como textos e a interpretação como atribuição de sentidos e significados das experiências individuais e coletivas. "Ao produzir saber, ao dizer como as coisas são, o homem produz a racionalidade, evidenciando uma estreita relação entre os dois termos - saber e racionalidade" (HERMANN, 2003, p. 13).

A história de vida e a história oral tiveram seu reconhecimento epistemológico no âmbito do movimento etnometodológico. Segundo Minayo (2004) a etnometodologia teve como berço a Universidade de Chicago, e como seu principal arquiteto Robert Park que, desde ás décadas de 1920 e 1930 defende a importância da experiência direta com os atores sociais para a compreensão de sua realidade.

Recorro a Schemeil (1999 apud Macedo, 2006, p. 62) que nos aponta, para além das diferenças teóricas, a unidade paradigmática entre as formulações dos maiores expoentes da Escola de Chicago - Park, Thomas, Burgess e Mckenzie -, que rompem com a metafísica da modernidade abandonando a noção iluminista de objetividade e apontando a necessidade da compreensão das realidades antropossociais. Nesse movimento é que surge a metodologia autobiográfica, que segundo Josso (2004), dá legitimidade à mobilização da subjetividade como modo de produção do saber e à intersubjetividade como suporte do trabalho interpretativo e de construção de sentido para os auto-relatos.

Do ponto de vista metodológico, a abordagem biográfico-narrativa assume a complexidade e a dificuldade em atribuir primazia ao sujeito ou à cultura no processo de construção de sentido. Ao longo de seu percurso pessoal, consciente de suas idiossincrasias, o indivíduo constrói sua identidade pessoal mobilizando referentes que estão no coletivo. Mas, ao manipular esses referentes de forma pessoal e única, constrói subjetividades, 
também únicas. Nesse sentido, a abordagem biográfico-narrativa pode auxiliar na compreensão do singular/universal das histórias, memórias institucionais e formadoras dos sujeitos em seus contextos, pois revelam práticas individuais que estão inscritas na densidade da História.

A pesquisa deve, como toda prática social, assumir ideologicamente seus valores e seus vínculos de toda ordem: classe, gênero, raça, religião, etc. As subjetividades, na dialética jogo-jogante/jogo-jogado, têm sido trazidas à cena teórica por autores como Nóvoa e Finger (1988), Ferrarotti (1988), Catani $(2005,2003)$ e Catani e outros $(1997,1998)$, além de Queiroz (1988) e Demartini (1988). Todos esses autores têm contribuído para pensarmos, no campo da educação, a articulação entre as pressões reais da vida, a consciência e as intencionalidades em um novo paradigma interpretativo, no qual as narrativas se legitimam como fontes imprescindíveis, ainda que não as únicas, de compreensão dos fenômenos humanos.

É inevitável, portanto, pensarmos em algumas questões de opção teórica, enquanto pesquisadores, quando nos vemos imbricados no processo de ouvintes sensíveis das experiências de quem olha, retrospectivamente, para sua vida procurando os sentidos de suas opções. Por isso é pertinente a problematização metodológica, que se inicia pela reflexão sobre as formas de ouvir, registrar e interpretar as narrativas. Primeiro, é importante apresentar a concepção de narrativa com a qual estamos trabalhando. Narrar é enunciar uma experiência particular refletida sobre a qual construímos um sentido e damos um significado. Garimpamos em nossa memória, consciente ou inconscientemente, aquilo que deve ser dito e o que deve ser calado. Queiroz (1981, p. 19) define narração como “o relato do narrador sobre a sua existência através do tempo, tentando reconstruir os acontecimentos que vivenciou e transmitir a experiência que adquiriu". A referida autora apresenta uma distinção entre as narrativas como depoimento e como história de vida, levando-se em consideração o papel do pesquisador e a forma que utiliza para recolha dos dados.

No trabalho de coleta de depoimentos o investigador dirige o informante diante do objeto e das questões que pesquisa, ou seja, é o pesquisador quem dirige e conduz a entrevista frente aos acontecimentos da vida do informante que possam ser incluídos no trabalho. Na história de vida, diferente do depoimento, quem decide o que deve ou não ser contado é o ator, a partir da narrativa da sua vida, não exercendo papel 
importante à cronologia dos acontecimentos e sim o percurso vivido pelo sujeito. Ainda que o pesquisador dirija a conversa, de forma sutil, é o informante que determina o "dizível" da sua história, da sua subjetividade e dos percursos da sua vida.

Percebo que as pesquisas com história de vida têm utilizado terminologias diferentes com o objetivo de demarcar a menor ou maior autonomia discursiva do entrevistado, interesse na totalidade das experiências dos sujeitos ou nos recortes temáticos, os relatos em grupos ou individualizados, etc., mantendo, para além dessa diversidade de enfoque dos aspectos metodológicos, a unidade que lhes dá a valorização das fontes orais.

Autobiografia, biografia, relato oral, depoimento oral, história de vida, história oral de vida, história oral temática, relato oral de vida e as narrativas de formação são modalidades tipificadas da expressão polissêmica da história oral. Nas pesquisas na área de educação adota-se a história de vida, mais especificamente o método autobiográfico e as narrativas de formação, como movimento de investigação-formação, seja na formação inicial ou continuada de professores/professoras. Classificada como método, como técnica e ora como método e técnica, a abordagem biográfica, também denominada história de vida, apresenta diferentes variações face ao contexto e campo de utilização. Evidenciamos, com base em Queiroz (1988), que a abordagem biográfica tanto é método, uma vez que adquiriu, em seu processo de consolidação, vasta fundamentação teórica, quanto é técnica, na formulação de várias propostas de maneiras diferenciadas para sua utilização. As variadas tipificações ou classificações no uso do método biográfico inscrevem-se no âmbito de pesquisas sócio-educacionais como uma possibilidade de, a partir da voz dos atores/atrizes sociais, recuperar a singularidade das histórias narradas por sujeitos históricos, socioculturalmente situados, garantindo às mesmas o seu papel de construtores da história individual/coletiva intermediada por suas vozes. Assim, para Nóvoa e Finger (1988, p. 116),

as histórias de vida e o método (auto)biográfico integram-se no movimento actual que procura repensar as questões da formação, acentuando a idéia que 'ninguém forma ninguém' e que 'a formação é inevitavelmente um trabalho de reflexão sobre os percursos de vida'.

Outra questão importante é indicar como concebemos o papel do pesquisador no processo de recolha das fontes e elaboração do conhecimento. Não concordamos com as posições que reduzem o papel do pesquisador à 
mera descrição, argumentando que toda interpretação implica traição à essência do discurso do outro. O papel do pesquisador não pode limitar-se a tomar notas, pois sua tarefa é a escuta sensível na qual perceba os componentes e dimensões relevantes na vida dos sujeitos que lancem luz sobre as problemáticas construídas. Os relatos somente são relevantes porque respondem à historicidade e subjetividade dos sujeitos em suas itinerâncias e formação. Desta forma, pretendemos aprofundar a compreensão e reafirmar a utilização da pesquisa histórica e da narrativa (auto)biográfica, como opção metodológica para a presente pesquisa, visto que possibilita inicialmente um movimento de investigação sobre o processo de formação e por outro lado permite, a partir das narrativas (auto)biográficas, entender os sentimentos e representações dos atores sociais no seu processo de formação.

NARRATIVAS E ESCRITAS DE SI: ABORDAGEM EXPERIENCIAL E PRÁTICAS DE FORMAÇÃO

Tomar a escrita de si como um caminho para o conhecimento, numa perspectiva hermenêutica, não se reduz a uma tarefa técnica ou mecânica. O pensar em si, falar de si e escrever sobre si emergem em um contexto intelectual de valorização da subjetividade e das experiências privadas. Neste sentido, o conceito de "si mesmo" é, como todo conceito, uma proposta organizadora de determinado princípio de racionalidade. $\mathrm{O}$ falar de si hermenêutico, que defendemos como meio formativo neste artigo, é muito diferente do falar de si movido por metafísica teológica ou pragmatista. A epistemologia da modernidade criticou a metafísica medieval e teológica deslocando a verdade de uma dogmática religiosa para a dogmática racionalista. O pressuposto principal da racionalidade moderna é a separação sujeito /objeto e a crença de que é passível de conhecimento apenas o que for possível ser medido, ordenado, comparado, etc. Logo a subjetividade deveria ser exorcizada da ciência. Os cientistas deveriam escrever sobre o que eles pesquisam e não sobre o que eles são, deveriam escrever sobre suas descobertas e não sobre suas crenças e valores.

No campo da educação, conforme aponta Josso (2004) estamos vivenciando, a partir dos últimos vinte anos do século vinte, o desenvolvimento de uma sensibilidade à história dos aprendentes. Como pensar, a partir do reconhecimento da importância da subjetividade, a formação docente? No 
que e de que forma ela pode contribuir para uma profissionalidade docente mais conseqüente?

Os estudos das histórias de vida no campo educacional centram-se na pessoa do professor, com ênfase nas subjetividades e identidades que as histórias comportam. Com a centralização dos estudos e práticas de formação na pessoa do professor, busca-se abordar a constituição do trabalho docente levando-se em conta os diferentes aspectos de sua história: pessoal, profissional e organizacional, percebendo-se uma tomada de consciência que nos leva a reconhecer os saberes construídos pelos professores, no seu fazer pedagógico diário, o que não acontecia anteriormente nos modelos de formação de professores. Novos conceitos para a compreensão do trabalho docente surgiram com os estudos educacionais, cujas abordagens de pesquisa passaram a reconhecer o professor como sujeito, trazendo à tona a necessidade de se investigarem os saberes de referência dos professores sobre suas próprias ações e pensamentos caracterizando-os, inclusive, como sujeitos de um saber e de um fazer inerentes à profissão.

Através da abordagem biográfica o sujeito produz um conhecimento sobre si, sobre os outros e o cotidiano, revelando-se através da subjetividade, da singularidade, das experiências e dos saberes. A centralidade do sujeito no processo de pesquisa e formação sublinha a importância da abordagem compreensiva e das apropriações da experiência vivida, das relações entre subjetividade e narrativa como princípios, que concede ao sujeito o papel de ator e autor de sua própria história.

A pesquisa com histórias de vida inscreve-se neste espaço onde o ator parte da experiência de si, questiona os sentidos de suas vivências e aprendizagens. A escrita da narrativa abre espaços e oportuniza, às professoras e professores em processo de formação, falar-ouvir e ler-escrever sobre suas experiências formadoras, descortinar possibilidades sobre a formação através do vivido. A construção da narração inscreve-se na subjetividade e estrutura-se num tempo, que não é linear, mas num tempo da consciência de si, das representações que o sujeito constrói de si mesmo.

No âmbito da história da educação as pesquisas (auto)biográficas tem apresentado contribuições férteis para a compreensão da cultura e do cotidiano escolar, da memória material da escola e se apropriado das escritas (auto)biográficas, das narrativas de formação, como testemunhos, 
indicativos, das relações com a escola, visto que no "[...] campo especifico da história da educação, a inclusão dessas fontes participa de um movimento de renovação de opções teórico-metodológicas e temáticas, característico das duas últimas décadas [...]" (CATANI, 2005, p. 32).

As pesquisas desenvolvidas no Grupo de Pesquisa Autobiografia Formação e História Oral (GRAFHO), no âmbito do Programa de PósGraduação em Educação e Contemporaneidade (PPGEduC) vinculam-se a abordagem experiencial e as histórias de vida, as quais organizam-se a partir de projetos do grupo e de suas respectivas linhas de pesquisa. Cabe destaque os trabalhos de Liane Figueiredo Soares e de Selma Assis. O primeiro intitula-se Olga Mettig: história de vida e pensamento pedagógico, objetivando destacar a importância dessa professora para a educação na Bahia, ao analisar sua história de vida, resgatando os saberes, seu pensamento pedagógico e a realidade educacional da Bahia durante os anos de 1950 a 1970, época de maior produção intelectual da educadora. O segundo estudo tem como foco, Imagens e Representações das Ex-Normalistas da Escola Nossa Senhora do Carmo: um estudo sobre identidade de gênero e formação docente (1948 - 1982), e pretende contribuir para a análise da formação docente e ampliação da constituição da história educacional na Bahia, visando analisar as imagens e representações de gênero de ex-normalistas a partir de seus processos formativos. O termo identidade, aqui evidenciado, expressa a forma dos indivíduos se reconhecerem e serem reconhecidos, a partir do viés de gênero.

Ao estudar as Histórias de mestras, memória e identidade: o significado de ser professora do Instituto de Educação Gastão Guimarães (IEGG), Rita Carneiro propõe investigar os processos de construção/reconstrução identitárias de um grupo de professoras aposentadas do Instituto e a relação desses processos com as memórias de suas vivências/experiências na instituição. O Instituto de Educação Gastão Guimarães (IEGG), antiga Escola Normal de Feira de Santana, foi a principal instituição de formação de professores de Feira de Santana e região. Milhares de professores tiveram sua formação inicial nesta instituição e muitos professores e professoras viveram ali a sua profissionalidade. Durante muitas décadas trabalhar no IEGG representou prestígio e visibilidade social para os docentes. Mas, em razão das mudanças na legislação para a formação docente nos últimos anos da década de1990, a oferta de matrícula foi sendo reduzida, até o 
curso ser fechado em 2001. Para o grupo estudado, a instituição permaneceu viva nas suas memórias, ao mesmo tempo que suas identidades foram reconstruídas.

Outro significativo estudo desenvolvido no interior da linha de pesquisas - (Auto)biografia formação de professores e de leitores é o trabalho de Geisa Arlete, intitulado A história de vida e o ciclo profissional: uma reflexão sobre o abandono da docência, ao que busca compreender as possíveis relações entre o abandono da profissão docente, a história de vida e o ciclo de vida profissional de professores da cidade de Salvador - BA, com base em fontes do Departamento de Saúde do Sindicato de Professores do Estado da Bahia (SINPRO/BA), no período entre 1995-1998.

Os estudos que se apropriam da abordagem experiencial e que tomam as histórias de vida como prática de formação, no âmbito do grupo têm se configurado como uma vertente de pesquisa-formação e vem se debruçando sobre histórias de leitura, estágio supervisionado e narrativas de autoformação de professores de educação infantil. Ao discutir sobre as Histórias de vida e formação de leitores: a biblioteca móvel Anísio Teixeira, Zélia Malheiro Marques, busca através das histórias de vida, compreender práticas de leitura, especialmente na zona rural da cidade de Caetité, sudoeste baiano, na qual a biblioteca da Casa Anísio Teixeira, desenvolve programas de leitura para as escolas rurais multisseriadas do município, que têm como idéia-chave o ato de ler como propiciador de novos leitores e de produtores de textos. Numa perspectiva semelhante, Neurilene Martins Ribeiro pretende discutir em seu estudo, Tornar-se professor na profissão: narrativas de professoras de Lingua Portuguesa nos anos iniciais de carreira, de que modo os docentes de Língua Portuguesa da Chapada Diamantina tornam-se professores no exercício da profissão, investigando as teias de relações constitutivas dos processos que forjam a construção das identidades e subjetividades dos(as) professores(as), com ênfase nas biografias profissionais; nos contextos formativos nos quais estão inseridos(as); nas práticas de formação oferecidas pelas instituições em que trabalham, ao dialogar com as práticas de formação continuada que assumem a história de vida como processo de formação e autorformação. Ampliando o campo de pesquisa com as histórias de vida no grupo, em seu trabalho sobre, Tornar-se professor de Educação Infantil: histórias de vida e (auto) formação, Leomárcia Uzeda procura analisar como os professores entendem, percebem os dilemas, desafios, dificuldades em suas 
trajetórias profissionais, ao refletir sobre a construção da identidade da professora de educação infantil no exercício da profissão. Por fim, o trabalho Estágio supervisionado e narrativas de formação, de Ana Jovina Carvalho, tem como foco o estágio no curso de Pedagogia desenvolvido no Campus IX (Barreiras - Bahia) e seu papel no curso do de formação, recorrendo às (auto)biografias. A partir da análise interpretativa dos diários de estágio e da escrita narrativa da trajetória escolar, pretende compreender as itinerâncias no processo formativo, identificar conceitos de estágio que permeiam o curso, as formas como vem sendo desenvolvido ao contribuir para a superação do reducionismo teoria-prática enfrentado pelo estágio supervisionado, como também oportunizar a estes profissionais conhecimentos teórico-metodológicos da abordagem (auto)biográfica, na perspectiva de ressiginificar o papel do estágio no processo de formação inicial.

Essas são também questões que me inquietam e que tenho refletido no campo da pesquisa formação, seja no âmbito da história da educação ou da formação inicial ou continuada de professores, a partir de uma outra epistemologia da formação e das aproximações e apropriações entre as (auto)biografias, história da educação e as práticas de formação.

\section{REFERÊNCIAS}

AUGÉ, Marc. As formas do esquecimento. Tradução de Ernesto Sampaio, Lisboa: Imanedições, 1998.

BUENO, Belmira Oliveira et al. Histórias de vida e autobiografias na formação de professores e profissão docente (Brasil, 1985-2003). Educação e Pesquisa, v. 32, n. 2, p. 385-410, 2006.

BOSI, Ecléa. O tempo vivo da memória. São Paulo: Ateliê Editorial, 2003. CATANI, Denice Bárbara (Org.) et al. Docência, memória e Gênero: estudos sobre formação. São Paulo: Escrituras Editora, 1997.

- A vida e o ofício dos professores: formação contínua, autobiografia São Paulo: Escrituras Editora, 1998.

CATANI, Denice Bárbara. As leituras da própria vida e a escrita de experiências de forma. Revista da FAEEBA - Educação $e$ Contemporaneidade, Salvador, v. 14, n. 24, p. 31-40, jul./dez. 2005.

. Lembrar, narrar, escrever: memória e autobiografia em história da educação e em processos de formação. In: BARBOSA, Raquel Lazzari 
Leite (Org.) Formação de educadores: desafios e perspectivas. São Paulo: Editora UNESP, 2003. p. 119-130.

CONGRESSO INTERNACIONAL DE PESQUISA (AUTO)BIOGRÁFICA. Anais... Porto Alegre: PUCRS 2004.

CONGRESSO INTERNACIONAL DE PESQUISA (AUTO)BIOGRÁFICA. 2., 2006, Salvador. Anais... Salvador: EDUNEB, 2006.

DEMARTINI, Zeila de Brito Fabri. Histórias de vida na abordagem de problemas educacionais. In.: SIMSON, Olga de Morares Von (Org.). Experimentos com história de vida. São Paulo: Vértice/Revista dos Tribunais, 1988. p. 44-105.

FERRAROTI, Franco. Sobre a autonomia do método biográfico. In: NÓVOA, António; FINGER, Mathias. O método (auto)biográfico e a formação. Lisboa: MS/DRHS/CFAP, 1988.

HERMANN, Nadja. Hermenêutica e Educação. Rio de Janeiro: DP\&A, 2002.

JOSSO, Marie-Christine. Experiências de vida e formação. São Paulo: Cortez, 2004. 2006. . Etnopesquisa Crítica, Etnopesquisa formação. Brasília: Líber livro,

MINAYO, Maria Cecília de Souza. O desafio do conhecimento: pesquisa qualitativa em saúde. 8. ed., São Paulo: Hucitec, 2004.

NAJMANOVICH, Denise. O sujeito encarnado: questões para pesquisa no/ do cotidiano. Rio de Janeiro: DP\&A, 2001.

NÓVOA, António; FINGER, Mathias. O método (auto)biográfico e a formação. Lisboa: MS/DRHS/CFAP, 1988.

PINEAU, Gaston. As histórias de vida como artes formadoras da existência. In: SOUZA, Elizeu Clementino de; ABRAHÃO, Maria Helena Menna Barreto (Org.) Tempos, Narrativas e Ficções: a invenção de si. Porto Alegre: EDPUCRS; Salvador: EDUNEB, 2006, p. 42-59.

QUEIROZ, Maria Isaura Pereira de. Variações sobre a técnica de gravador no registro da informação viva. Cadernos do CERU, São Paulo, n. 16, p. 107-115, nov. 1981 .

Relatos Orais: do “indizível” ao "dizível”. In.: SIMSON, Olga de Morares Von (Org.). Experimentos com história de vida. São Paulo: Vértice/ Revista dos Tribunais, 1988. p. 14-43.

ROCHA, Antonio Penalves. Tempo histórico e civilização material. In: LOPES, Marcos Antônio (Org.) Fernand Braudel: tempo e história. Rio de Janeiro: Editora FGV, 2003.

ROMANELLI, Otaíza de Oliveira. História da Educação no Brasil. 11. ed. Petrópolis: Vozes, 1989. 
SOUZA, Elizeu Clementino (Org.). Autobiografias, histórias de vida e formação: pesquisa e ensino. Porto Alegre: EDPUCRS; Salvador: EDUNEB, 2006, 372 p.

SOUZA, Elizeu Clementino de. O conhecimento de si: narrativas do itinerário escolar e formação de professores. 2004, 344 f. Tese (Doutorado em Educação) Programa de Pós-graduação em Educação, Faculdade de Educação, Universidade Federal da Bahia, Salvador.

SOUZA, Elizeu Clementino de. História de vida e formação de professores: um olhar sobre a singularidade das narrativas (auto) biográficas. In: MACEDO, Roberto Sidney (Org.). Currículo e docência: tensões contemporâneas interfaces pós-formais. Salvador: Editora da UNEB, 2003. p. $35-56$.

SOUZA, Elizeu Clementino de; SOUSA, Cynthia Pereira de; CATANI, Denice Barbara. La reserche (auto)biographique et l'invention de soi au Bresil. Colloque International (1986-2007) Le Biographique, la réflexivité et les temporalités. Articuler Langues, cultures et formation. Université FrançoisRabelais, 25-27 juin 2007, Tours-França.

SOUZA, Elizeu Clementino de; MENEZES, Jaci Maria Ferraz. História da Educação na Bahia: recortes e aproximações sobre a constituição do campo. In: VASCONCELOS, José Gerardo; NASCIMENTO, Jorge Carvalho (Org.). História da Educação no Nordeste Brasileiro. Fortaleza: UFC Edições, 2006, p. 136-153.

SOUZA, Elizeu Clementino de; ABRAHÃO, Maria Helena Menna Barreto (Org.) Tempos, Narrativas e Ficções: a invenção de si. Porto Alegre: EDPUCRS; Salvador: EDUNEB, 2006.

SOUZA, Elizeu Clementino; FORNARI, Liege Maria Sitja. Colégio Nossa Senhora do Carmo: memória, história institucional e representações sobre a formação docente. In: FERRAZ, Jaci Maria et al. Educação na Bahia: memória, registros, testemunhos. Salvador: EDUNEB, 2005. p. 347-356. 


\section{Contribuição historiográfica ao debate sobre ações afirmativas: exclusão racial na Bahia do século XIX}

Wilson Roberto de Mattos

As influências nacionais da Conferência Mundial contra o Racismo, Discriminação Racial, a Xenofobia e Formas Conexas de Intolerância, realizada em 2001, na cidade de Durban - África do Sul; a implantação do sistema de reserva de vagas para candidatos negros em mais de 40 universidades públicas brasileiras e a edição da Lei Federal n ${ }^{\circ}$ 10.639/2003, provocaram uma profunda reorientação nos temas que comumente têm freqüentado as discussões sobre o Brasil contemporâneo e as relações com o seu passado histórico.

De um espectro que vai das elites econômicas aos setores populares, passando, como sempre, pelas mãos severas e determinantes das elites acadêmicas, é notório um certo mal-estar diante do fato de que as populações negras, seguramente, pela primeira vez na história do Brasil, passam a se constituir como as principais beneficiárias de um conjunto de políticas públicas nacionais reparadoras de desigualdades que se arrastam, desde a escravidão - como veremos logo adiante -, transformando o Brasil em um dos países mais racialmente excludentes do mundo.

Mal-estar ainda maior tem sido notado, dessa vez somente entre as elites acadêmicas, quando, também pela primeira vez, impulsionado pelo mesmo conjunto de acontecimentos e seus desdobramentos, um número expressivo de intelectuais negros e negras, sobretudo, mas não exclusivamente, no interior 
das universidades, ameaçam a hegemonia e supremacia racial branca. Hegemonia essa que, desde tempos remotos, reserva aos brancos a prerrogativa quase que exclusiva de saber e dizer o que é o Brasil, sua história, sua identidade, suas perspectivas, sua memória e, principalmente, determinar como deve organizar-se e por quem devem ser freqüentados, os seus centros autorizados de produção desses saberes e dizeres.

Sentindo-me provocado a entrar nesse debate de uma maneira mais apropriada ao meu próprio campo de formação e da posição que ocupo como militante negro no interior do universo acadêmico, no presente texto trago à reflexão um pequeno aspecto da histórica exclusão racial das populações negras do universo da cidadania, dos direitos e das oportunidades, como forma de ampliar o entendimento da justiça e necessidade de adoção, nos tempos atuais, de ações afirmativas como medidas reparatórias.

Ao mesmo tempo realço a necessidade de nós, historiadores e outros cientistas sociais negros, através da pesquisa e de uma deliberada posição teórico-metodológica afinada com as nossas reais necessidades de crítica dos aspectos mais profundos, retoricamente obscurecidos e menos debatidos do racismo brasileiro, buscarmos a reconfiguração dos quadros da nossa memória, narrando a nossa própria história à nossa maneira.

Por razões óbvias retorno ao século XIX e, em especial, à sua segunda metade. Com os anúncios do inevitável fim da escravidão, os nossos destinos e as formas do nosso ingresso no âmbito da nacionalidade livre, estavam sendo cuidadosamente arquitetado pelas elites brancas da época. A questão era: como garantir a posição de elite econômica, política e cultural, diante de uma imensa "negrada" que ia se libertando a passos largos. Em outras palavras, como dar continuidade à subordinação de classe e de raça mantendo sob domínio a imensa maioria da população, não podendo mais valer-se do estatuo da escravidão.

Evidentemente, com as características históricas das elites brasileiras, a alternativa não poderia ser outra se não a opção deliberada pela exclusão social e racial. Do mercado de trabalho à educação, não houve setor social em que as populações negras não tivessem que enfrentar as ações discriminatórias, sabotadoras e proibidoras de qualquer tentativa de ascensão social, coletiva ou individual. 
Qualquer semelhança entre a segunda metade do século XIX e o início do século XXI; qualquer semelhança entre as tentativas de sabotar as possibilidades de ascensão social das populações negras, naquele período e no período presente; bem como qualquer coisa parecida entre o comportamento excludente das elites de lá e das elites de cá, não são meras coincidências. Ao menos em termos raciais, os excluídos são os mesmos e as elites também.

Vejamos então, com uma relativa riqueza de detalhes, um dos mais sutis, mas não menos eficazes processos de exclusão das populações negras: a ampliação progressiva da taxação sobre as atividades de trabalho livre desenvolvidas pelos negros na Bahia, em especial, os africanos, durante o século XIX, como forma de excluí-los do mercado de trabalho livre.

Ao lado de várias outras medidas legais claramente excludentes, a vertente fiscal da legislação escravista do século XIX baiano, indica evidências incontestáveis do que afirmo acima.

$\mathrm{Na}$ esteira das medidas repressivas contra os africanos, editadas imediatamente após a Revolta dos Malês, um dos maiores movimentos de revolta negra nas Américas, acontecido em Salvador, no mês de janeiro de 1835, ao lado de artigos que previam a expulsão dos africanos suspeitos, a proibição de que eles adquirissem bens de raiz, e a proibição de que alugassem casas, a legislação escravista passa a taxar todos os africanos, indistintamente, pelo simples fato de serem africanos.

$\mathrm{O}$ art. $8^{\circ}$ da Lei $\mathrm{n}^{\circ}$ 9, fixa para os africanos forros de ambos os sexos, que residissem ou fossem encontrados na Província, a imposição anual de $10 \$ 000$ rs., sem especificar a razão da incidência da taxa. Logo em seguida, no art. $9^{\circ}$, além de se prever uma premiação de $100 \$ 000$ rs. a qualquer africano que denunciasse algum projeto de insurreição, a Lei isentaria o denunciante de pagar taxa de $10 \$ 000$ rs. e, se ele fosse escravo, o libertaria pagando ao proprietário, o seu valor de mercado (LEGISLAÇÃO...,1996).

A Lei ${ }^{\circ} 14$, de 2 de junho de 1835, lei que institui capatazias encarregadas de policiar o serviço dos ganhadores negros ${ }^{1}$, determina no seu art. $3^{\circ}$, uma multa de $10 \$ 000$ rs. aos ganhadores que exercessem suas atividades sem se matricular, duplicando a multa em caso de reincidência. Tentando garantir

O termo "ganhadores", referia-se aos escravos e negros livres que trabalhavam nas ruas exercendo atividades mecânicas, artesanais, ou prestando algum serviço, como por exemplo, carregar volumes e gêneros ou cadeiras de arruar para o transporte de pessoas. 
a sua eficácia, a mesma lei impõe um arrolamento geral de todos os africanos residentes na Província com declaração de nome, idade provável, endereço de moradia e ocupação (LEGISLAÇÃO..., 1996).

Considerando o momento em que essas leis foram sancionadas, assim como suas características, pode-se dizer que a taxação sobre os africanos nasceu como forma de punição, controle e exclusão, e não como parte de uma política de arrecadação fiscal da Província. ${ }^{2}$

Em 1846, a taxação sobre os africanos começa a se especificar. Fixa-se o valor de $10 \$ 000$ rs. "para a licença a ser concedida pela repartição fiscal, a africanos livres de ambos os sexos, para poderem mercadejar, estabelecendo a multa de $50 \$ 000$ rs. a ser aplicada àqueles que não portassem a referida licença" (LEGISLAÇÃO..., 1996, p. 33). Estipula-se também uma taxa de $2 \$ 000$ rs. a ser cobrada pela Câmara da cidade da Bahia, por africano livre que se empregasse em saveiros ou cadeiras de aluguel (LEGISLAÇÃO..., 1996).

Não parece ter sido coincidência o fato da taxação direta sobre o trabalho dos escravos aparecer na mesma lei que proibia africanos e escravos de atracarem saveiros em determinados estações no cais da capital (FONSECA, 1988). Além das taxas já existentes que, indiretamente, envolviam os escravos, como as taxas de meia siza, as taxas de escravos despachados para fora da Província, e as taxas sobre escravos residentes nas cidades e vilas, a Lei $n^{\circ} 344$, no seu art. $2^{\circ}$, taxa em $10 \$ 000$ rs. os africanos livres, libertos ou escravos, ocupados em remar saveiros e alvarengas (LEGISLAÇÃO..., 1996). Existia, em 1846, uma lei que taxava em $2 \$ 000$, apenas os africanos livres empregados nessa atividade (LEGISLAÇÃO..., 1996), mas, em relação aos escravos, a Lei ${ }^{\circ} 344$, de 1848, é a primeira a taxar diretamente suas atividades de trabalho.

Ao que parece, a impossibilidade de exclusão imediata desses segmentos negros nas atividades de serviços urbanos, fez com que o poder público adotasse o mecanismo da taxação progressiva e ascendente, não só como forma de aumentar as rendas provinciais, mas como estratégia indireta

\footnotetext{
Um estudo de Moraes (1950, p. 182) intitulado O escravo na legislação tributária da Província da Bahia, apesar de só parcialmente dar conta daquilo que se propõe, informa que até 1832 , a despeito da existência de cobrança de impostos durante todo o período colonial, não existia propriamente um sistema tributário no Brasil. No período colonial os impostos eram considerados receita privada do rei. As províncias só passaram a ter direitos privativos sobre a cobrança de impostos, a partir de uma lei geral do Império editada em 1835.
} 
para alcançar o objetivo da exclusão, num lapso de tempo suficiente para articular formas de substituição da mão-de-obra africana e escrava, nesses ramos de atividades. Dessa forma, a necessária continuidade dos serviços não ficaria comprometida. Vejamos essa progressividade.

No ano seguinte à edição da Lei ${ }^{\circ} 344$, a taxa sobre remadores de saveiros e alvarengas, sobe para $20 \$ 000$ rs. (LEGISLAÇÃO..., 1996). Em 1850 , observa-se um novo aumento, e um desmembramento na incidência da taxa. A Lei $n^{\circ} 405$, sancionada neste ano, no parágrafo 27 , estipula a

taxa de 30\$000rs. sobre africano livre, liberto ou escravo que se ocupasse em remar saveiros ou outra embarcação que servisse para desembarque, e a de $20 \$ 000$ rs. por cada africano livre, liberto ou escravo que se ocupasse em remar alvarengas ou qualquer outra embarcação de descarga (LEGISLAÇÃO..., 1996, p. 40).

Dados quantitativos reunidos por Cunha (1985), asseguram uma presença significativamente majoritária de trabalhadores negros empregados na lide do mar, o que certamente não passou despercebido aos olhos do poder público. Para o ano de 1856 em Salvador, de um total de 3.503 trabalhadores do mar, 43,3\% eram escravos, e entre esses escravos, 98,1\% eram pretos, contrastando com ínfímos 1,9\% de pardos (CUNHA, 1985).

Se considerarmos que, à época, o termo designativo "preto", não era só atributo da cor da pele, mas servia, principalmente, para designar os africanos, procede levantar a hipótese de que a presença deles era massiva nas atividades do mar pois, mesmo entre os trabalhadores marítimos livres, os pretos representavam 32,2\% (CUNHA, 1985).

Os dados sobre os trabalhadores marítimos na Província da Bahia como um todo, apontam para uma forte diminuição da proporção de escravos nesse ramo de atividade a partir da década de 1860. De 30,7\% em 1862, os escravos passam a representar apenas 9,8\% em 1874. Cunha (1985) afirma ainda que as medidas de exclusão do início da década de 1850 , foram responsáveis pelo desemprego de 750 africanos.

A taxação progressiva, estendeu-se, praticamente, a todas as atividades que, de uma forma ou de outra, envolvia os escravos ganhadores e os africanos libertos.

Em 1855 inaugura-se a taxa de $100 \$ 000$ rs. sobre escravo que se matriculasse como marinheiro. Aumenta-se a mesma taxa para $150 \$ 000$ rs., em 1863; 200\$000rs., em 1864; 240\$000rs., em 1876; e, em 1877, diminui 
para 200\$000rs., onde se estabiliza até o final da escravidão (LEGISLAÇÃO...,1996).

Os escravos ganhadores, aqueles que exerciam suas atividades de trabalho nas ruas longe do controle direto dos seus senhores, são taxados anualmente, de 1857 até 1881. Essa taxa, inicialmente de 3\$000rs., sobe para 5\$000rs., onde permanece até 1875; depois, sobe para 10\$000rs., nos anos de 1876 e 1877; aumenta para 15\$000rs., em 1878 e 1879; e termina em 20\$000rs., no ano de 1881 (LEGISLAÇÃO..., 1996). Segundo o Inspetor do Tesouro Provincial, Dr. Gustavo Adolfo de Sá - em relatório apresentado ao Presidente da Província, Dr. Antônio de Araújo Aragão Bulcão - “pela expressão, escravo ganhador, se deve entender todo o escravo que estiver à ganho ou alugado, seja qual for o serviço em que se empregue" 3 .

A Lei ${ }^{\circ} 420$ de 7 de junho de 1851, impõe, pela primeira vez, a taxa de 10 \$000rs. sobre todo africano que exercesse ofício mecânico. Dois anos depois essa taxa passa a incidir também sobre escravos que exercessem os mesmos ofícios (LEGISLAÇÃO..., 1996). Entretanto, a legislação toma o cuidado de isentar dessa taxa, aqueles escravos que estivessem ligados ao serviço da lavoura.

A quase interminável relação dos trabalhadores cujas profissões incluemse na categoria de ofícios mecânicos, nos informa sobre a dimensão da intervenção do poder público no controle das atividades urbanas de trabalho, tanto quanto nos permite desmentir a idéia veiculada pela historiografia oficial de que os negros não tinham preparo para o ingresso no mundo do trabalho livre e qualificado. Segundo o título XVIII do Regulamento de 20 de agosto de 1861 editado pela Presidência da Província, eram considerados ofícios mecânicos os de: abridor, armeiro, alfaiate, asfalteiro, barbeiro, cravador, caldeireiro, coronheiro, correeiro, chapeleiro, cabeleireiro, charuteiro, carapina, carpinteiro, cordoeiro, calafate, calceteiro, canteiro, cavouqueiro, curtidor, dourador, espingardeiro, escultor, entalhador, encadernador, empalhador, envernizador, ferrador, ferreiro, funileiro, fogueteiro, lapidário, lavrante, latoeiro, livreiro, marceneiro, ourives, pintor, polieiro, pedreiro, relojoeiro, serralheiro, sirgueiro, surrador, seleiro, segeiro, sapateiro, serrador, tintureiro, tecelão, torneiro, tamanqueiro, tanoeiro, vidraceiro (LEGISLAÇÃO..., 1996).

APEB - Arquivo Público do Estado da Bahia / Biblioteca. Relatório apresentado em 2 de abril de 1880. Essa definição de escravo ganhador, é uma correção feita pelo Inspetor do Tesouro, ao art. 218 do Regulamento de 20 de agosto de 1861, que orientava a cobrança de impostos. 
De 1873 a 1877, as leis passaram a especificar diferenças no valor do imposto que incidia sobre os escravos que exercessem seus ofícios mecânicos na capital e seus subúrbios (10\$000rs.), daqueles que os exercessem nas demais cidades e vilas da Província ( $5 \$ 000$ rs). Observa-se um aumento respectivo para 20\$000rs., e $10 \$ 000$ rs., na lei de 1876 , e na lei de 1877 (LEGISLAÇÃO..., 1996).

A partir de 1878, desaparece da legislação a diferença de valor entre a incidência da taxa na capital, e nas outras cidades. As leis subseqüentes passam a taxar em 20\$000rs., indistintamente, todos os escravos que exercessem ofício mecânico. Essa taxa perdura até 1886, último registro da sua presença na legislação escravista do século XIX baiano (LEGISLAÇÃO..., 1996).

Walfrido de Moraes, no seu estudo sobre os impostos que incidiam sobre os escravos durante o século XIX, informa que em 1887, ano de exercício da Lei orçamentária de 1886, foi arrecadado com a cobrança da taxa sobre escravos que exerciam ofício mecânico, apenas $20 \$ 000$ rs., ou seja, apenas um escravo foi taxado. Quanto à cobrança de taxa sobre compra e venda de escravos, informa ainda o autor, a sua arrecadação, no mesmo ano, foi zero (MORAES, 1950). Obviamente a "causa mortis" desses impostos, foi inanição.

É obvio que a escravidão teve um peso fundamental na vitalidade financeira da Província. Além das taxas acima especificadas, houve outras, tais como, as que incidiam sobre o transporte em cadeiras de arruar, licenças para mercadejar, contratos de compra e venda de escravos, e as taxas sobre escravos matriculados como marinheiros. É necessário considerar também as multas que incidiam sobre aqueles que burlassem o pagamento dessas taxas.

A Lei n ${ }^{\circ} 1.054$ de 27 de junho de 1868, na parte referente à receita do orçamento provincial para o ano financeiro de 1868-1869, faz previsões de que, só com os impostos envolvendo escravos, os cofres públicos arrecadariam: 81:630\$340rs., com a meia siza sobre a compra de escravos; 5:487\$500rs., com a taxa sobre escravos que exercessem ofícios mecânicos; 51:233\$610rs., com a taxa por escravos que fossem despachados para fora da Província, e 3:000\$000rs., com a taxa sobre escravos matriculados como marinheiros (LEGISLAÇÃO..., 1996).

Somando-se esse montante, a previsão do governo provincial é de que arrecadaria, somente com esses impostos, 141:351\$450rs. Quantia essa, 
suficiente para comprar 321 escravos do sexo masculino, de acordo com seu preço médio nesse período. Segundo Andrade (1988), o preço médio de um escravo do sexo masculino em 1868 era 440\$071rs.

Um relatório técnico do Inspetor do Tesouro Provincial, apresentado ao Presidente da Província em 1878, é indicativo da necessidade que o governo tinha de cobrar esses impostos. Escreve o Inspetor que,

\begin{abstract}
os diversos impostos sobre escravos, a saber: A meia siza sobre os que são despachados para fora da Província, os ganhadores e os que exercem officio mechanico, tendem a diminuir progressivamente, até que finalmente cessem de todo. É necessário que o poder competente cuide em crear fontes de receita que, proporcionalmente, vão substituindo o desfalque que a diminuição na renda de taes impostos vai deixando nos orçamentos. O deficit final será superior a 300:000\$000, em relação ao que elles já produzirão ${ }^{4}$
\end{abstract}

Ainda que esses dados indiquem que o peso dos impostos que incidiam, direta ou indiretamente, sobre os escravos e suas atividades de trabalho, não foi pequeno na composição do orçamento provincial, isso não anula a hipótese, anteriormente levantada, de que a taxação progressiva e ascendente, sempre precedida de arrolamentos e matrículas, além de cumprir a óbvia função de aumentar as rendas provinciais, significou um expediente proibitivo, complementar às tentativas mais notórias de exclusão dos escravos e africanos das atividades de trabalho urbano. Sobretudo aquelas atividades nas quais esses negros desfrutavam de uma relativa autonomia.

Informando tal hipótese, uma observação geral sobre o conjunto das leis de arrecadação orçamentária entre os anos de 1835 e 1888, aponta um dado que merece ser mencionado.

Acompanhando essas leis, ano por ano, observa-se que os africanos livres que exerciam ofícios mecânicos, são taxados pela última vez, em 1863 (LEGISLAÇÃO..., 1996).

Há duas razões possíveis para o desaparecimento da cobrança dessa taxa. Uma seria o governo provincial ter, deliberadamente, aberto mão da cobrança de taxas sobre as atividades de trabalho dos africanos livres. A outra, a que nos parece mais provável, é que a própria cobrança da taxa, e sua progressividade, teria contribuído para a redução do número de africanos empregados em ofícios mecânicos, tornando desnecessária a reedição das

\footnotetext{
4 APEB - Biblioteca. Relatório de 2 de abril de 1878, apresentado ao Presidente da Província Barão Homem de Mello pelo Bacharel Ignácio José Ferreira, Inspector do Thesouro Provincial da Bahia. 1878.
} 
leis de cobrança. Não se crê que o governo provincial deixaria de taxar os africanos empregados nesses ofícios, se o seu número fosse considerável. Aliás, a taxa sobre africanos que exerciam ofícios mecânicos existia desde 1851, se repetindo, ano a ano, em todas as leis orçamentárias, até deixar de ser cobrada a partir de 1863.

O último registro de cobrança de impostos sobre o trabalho dos africanos, é a Lei $\mathrm{n}^{\circ}$ 950, de 27 de maio de 1864, estabelecendo uma taxa de 20\$000rs. para cada africano, de ambos os sexos, que mercadejasse na capital e cidades do litoral. A partir daí, os africanos desaparecem da legislação orçamentária.

Evidentemente, isso não significa que eles tivessem deixado de exercer outras atividades. Cabe observar que 809 africanos estavam inscritos como ganhadores, entre os 1761 trabalhadores negros constantes do Registro de Matrícula de $1887^{5}$. Mas, esse mesmo Registro, indica que a redução do número de africanos que exerciam atividades mecânicas deve ter sido grande, pois, ao contrário de outros ganhadores matriculados e identificadas às suas profissões, não aparece nenhum africano com esse tipo de registro.

Em contrapartida, os escravos que exerciam ofícios mecânicos, e os escravos ganhadores - é bom que se repita, escravos cujo trabalho na rua, os livrava de um controle senhorial mais estreito -, muitos deles, provavelmente, arrimo dos seus senhores ${ }^{6}$, tiveram suas atividades de trabalho taxadas até a década de 1880 . Os primeiros, até 1886 , e os segundos até 1881(LEGISLAÇÃO..., 1996).

Somente os ganhadores livres, crioulos ou africanos, deixaram de ser taxados a partir de 1858 (LEGISLAÇÃO..., 1996). Certamente foi uma decorrência da vitória parcial obtida na greve dos ganhadores de $1857^{7}$. A principal reivindicação dos ganhadores em greve, era a abolição do

Registro feito pela Chefatura de Polícia, intitulado Registro de Matrícula dos Cantos de Ganhadores Livres. A riqueza desse documento está na profusão de detalhes que ele nos fornece sobre todos os trabalhadores negros registrado na cidade de Salvador: nome, idade, condição, local de trabalho e de moradia etc. APEB - Colonial/ Provincial. Séire Polícia. Maço 7116.

6 Ter escravos em Salvador no século XIX, não era prerrogativa exclusiva dos ricos. Muitos pobres, inclusive africanos libertos, adquiriam escravos, seja como forma de consolidar um "status" social diferenciador, ou, sobretudo, como forma de garantir a própria sobrevivência utilizando-se do escravo em atividades de ganho. Na cidade de Salvador, grande parte dos proprietários não possuíam mais do que 2 ou 3 escravos. Mais detalhes sobre isso podem ser encontrados no livro de Fraga Filho (1996) e na dissertação de mestrado de Sena Júnior (1997).

$7 \quad$ Com base em estudo de Reis (1993) sabemos que essa greve foi empreendida por negros ganhadores, se posicionando contrários às imposições de disciplinamento, controle e taxação sobre as suas atividades de trabalho, impostos pela Câmara Municipal de Salvador,em 1857. 
pagamento da taxa obrigatória que incidia sobre suas atividades. Depois de uma semana de greve a Câmara Municipal de Salvador, anulou a taxa. ${ }^{8}$

Procurei mostrar que, de alguma maneira, a parte fiscal da legislação escravista na Bahia, especialmente, a partir da segunda metade do século XIX, foi um dos componentes do quadro de exclusão social das populações negras, no âmbito do processo mais amplo de transição da hegemonia do trabalho escravo para a hegemonia do trabalho livre.

Evidentemente que ainda há inúmeros aspectos dessa exclusão que estão por ser pesquisados. A quem quer que se interesse, não será difícil encontrar em arquivos públicos de cidades brasileiras de passado escravista, pistas sobre os procedimentos e formas através das quais essa exclusão se efetivou.

Meu objetivo aqui foi, como dito anteriormente, entrar no debate sobre ações afirmativas, destacando, na história do Brasil, processos concretos que reforçam argumentos relativos à necessidade e justiça na adoção de tais medidas.

O que foi encontrado e, nesse texto, exibido como exemplo, não deixa dúvidas. As ações afirmativas como medidas construtoras da igualdade racial e, sobretudo, como medidas de reparação de discriminações e exclusões das populações negras, têm sua necessidade confirmada pela História. Portanto penso que qualquer manifestação contrária a essa necessidade, na melhor das hipóteses, implica em ignorância, ou, o que não queremos crer, em alguma razão inconfessável que não ousa dizer o nome publicamente.

\section{REFERÊNCIAS}

ANDRADE, Maria Jose de Souza. A mão-de-obra escrava em Salvador 1811-1860. São Paulo: Corrupio, 1988.

CUNHA, Manoela Carneiro da. Negros estrangeiros: escravos libertos e sua volta a África. São Paulo: Brasiliense, 1985.

FLEXOR, Maria Helena. Oficiais mecânicos na cidade do Salvador. Salvador: Prefeitura Municipal de Salvador, 1974.

FONSECA, Luis Anselmo da. A escravidão, o clero e o abolicionismo. Recife: Massangana, 1988. Edição fac-similar, 1887.

$8 \quad$ Cf. REIS, 1993. 
FRAGA FILHO, Walter. Mendigos, moleques e vadios na Bahia do séc. XIX. São Paulo: Hucitec; Salvador: Edufba, 1996.

LEGISLAÇÃO da Província da Bahia sobre o negro: 1835-1888. Salvador: Fundação Cultural do Estado da Bahia/Diretoria de Bibliotecas Públicas, 1996.

MALERBA, Jurandir. Os brancos da lei. Maringá: Editora da Universidade Estadual de Maringá, 1994.

MATTOS, Wilson Roberto de. Escravos astutos - liberdades possíveis: reivindicações de direitos, solidariedades, resistências e arranjos de sobrevivência em Salvador (1871-1888). In: SILVÉRIO, Valter Roberto et. al. (Org.) De preto a afro-descendente: trajetórias de pesquisa sobre relações étnico-raciais no Brasil. São Carlos: EDUFSCAR, 2003, p. 25-50.

. Valores civilizatórios afro-brasileiros, políticas educacionais e currículos escolares. Revista da FAEEBA - Educação e Contemporaneidade. Salvador, v. 12, n. 19, p. 247-252, jan./jun., 2003.

. CANTOS: trabalho, cultura e solidariedade. Africanos e crioulos em Salvador na segunda metade do século XIX. Revista Sementes - Ética da coexistência. Salvador, v. 2, n. 3 e 4, p. 114-128, jan./dez., 2001.

- Ações Afirmativas na Universidade do Estado da Bahia: razões e desafios de uma experiência pioneira. In: SILVA, Petronilha Beatriz Gonçalves et. al. (Org.). Educação e Ações Afirmativas: entre a injustiça simbólica e a injustiça econômica. Brasília: Instituto Nacional de Estudos e Pesquisas Educacionais Anísio Teixeira, 2003.

Inclusão social e igualdade racial no ensino superior baiano - uma experiência de ação afirmativa na Universidade do Estado da Bahia (UNEB). In: BERNARDINO, Joaze et. al. (Org.). Levando a raça a sério: ação afirmativa e universidade. Rio de Janeiro: DP\&A, 2004.

MORAES, Walfrido. O escravo na legislação da Província da Bahia. CONGRESSO DE HISTÓRIA DA BAHIA, 1., 1950, Salvador. Anais... Salvador: IGHB, 1950 , v. 4.

REIS, João José. A greve negra de 1857 na Bahia, Revista USP, São Paulo, n. 18, 1993.

SENA JÚNIOR, Carlos Zacarias F. de. Entre a pobreza e a propriedade: o pequeno proprietário de escravos em Salvador. 1850/1888. 1997. Dissertação (Mestrado em História) - Faculdade de Filosofia e Ciências Humanas, Universidade Federal da Bahia, Salvador, 1997. 



\title{
Branqueamento e branquitude: conceitos básicos na formação para a alteridade
}

\author{
Ana Célia da Silva
}

Esse artigo foi elaborado a partir do projeto de pesquisa, em processo, intitulado A diferença como prestígio: a representação social do branco no livro didático. Com essa pesquisa pretendo contribuir para a distinção entre os conceitos de branqueamento e branquitude, este último recente nos estudos brasileiros e que tem como precursoras as pesquisadoras da Psicologia Social da Universidade do Estado de São Paulo (USP), Iray Carone, Edith Piza e Maria Aparecida Silva Bento, bem como para a melhoria das relações étnico-raciais, na escola e na sociedade como um todo.

O interesse pelo objeto de investigação foi despertado inicialmente a partir de atitudes percebidas nas relações cotidianas na minha atividade profissional, de algumas pessoas de fenótipo branco ou assemelhado. Essas atitudes revelavam dificuldade em manter relações não hierárquicas, tendências a identificar o "outro" como ocupando espaços que não lhes são próprios, a tratá-lo como objeto de brincadeiras e elogiar a inteligência desse "outro" quando toma conhecimento da sua produção acadêmica. Porém o que mais me instigou foi um diálogo com uma criança de quatro anos, filho de um casal amigo, ele branco e ela parda. A criança tem a pele clara, cabelos lisos e traços fisionômicos indígena. Sempre que eu procurava abraçá-la ela dizia que não gostava de mim e me afastava. Um dia ela me disse muito zangada quando eu a abracei: - vou pintar você de preto. 
Respondi: - não precisa você não vê que eu sou preta? Ela retrucou: - você não é bem preta, você é preta clara. Eu disse: - e sua mãe? ela é preta? Ela deu um grito e disse: - minha mãe não é preta, é marrom e eu sou branco. A criança de pele clara quis me castigar me pintando de preto e distinguiuse se valorizando por ser branca.

Que fatores podem contribuir para uma criança de quatro anos já ter condições de hierarquizar as diferentes cores da pele, atribuindo um valor ao fato de ser branco?

Porque é tão importante ser ou parecer branco?

Qual o grau de prestígio econômico ou simbólico que esse grupo detém, para que muitos procurem assemelhar-se a ele?

A escola, o currículo e especificamente os livros didáticos, contribuem para a construção desse sentimento de superioridade por ter a pele clara e cabelos lisos, ser denominado e denominar-se branco?

Investigo a existência de representações sociais dos personagens brancos no livro didático de Língua Portuguesa das séries iniciais modelados no sentido de construir valoração positiva das diferenças fenotípicas e culturais desse grupo humano.

Tenho como hipótese a ser investigada, que os livros didáticos, através dos seus textos e ilustrações, contribuem em grande parte, para a construção de um sentimento de superioridade da população branca ou assemelhada, pelo valor que é atribuído às suas diferenças feno típicas e culturais, $\mathrm{O}$ processo da investigação pretende responder as seguintes questões centrais:

O livro didático de Língua Portuguesa de Ensino Fundamental de $1^{\circ}$ e $2^{\circ}$ ciclo contribui para a atribuição de valor às diferenças feno típicas e étnico/raciais do grupo humano branco?

A atribuição de valor às diferenças fenotípicas e étnico/raciais do grupo humano branco contribui para a formação de atitudes etnocêntricas e hierárquicas desse grupo étnico/racial em relação a outros grupos étnicos/raciais?

As palavras chaves da investigação são: representação social, hegemonia, branqueamento, branquitude. 
Nos caminhos a serem percorridos para coleta, análise e interpretação dos dados utilizei a abordagem qualitativa e utilizo o procedimento de análise de conteúdo, para caracterizar as mensagens expressas nos textos e ilustrações analisadas bem como "a descoberta do que está por trás dos conteúdos manifestos, indo além das aparências do que está sendo comunicado" (GOMES, 2004 apud MINAYO, 2004, p. 74).

Os livros objetos da investigação, em número de cinco, foram selecionados da última pesquisa realiza para obtenção do título de doutor, uma vez que os mesmos foram os que tiveram uma representação positiva dos personagens negros entre os desesseis livros pesquisados. Os dados obtidos serão analisados qualitativa e quantitativamente em suas ilustrações e texto, agrupados e categorizados. Subcategorias poderão ser construídas para maior explicitação da análise.

Alguns conceitos fundantes para uma reflexão sobre a problemática em questão.

\section{A REPRESENTAÇÃO SOCIAL}

Os estudos de representação social não são antigos. Tiveram início quando Moscovici criou o termo, escrevendo a sua obra La Psychanalise, son image e son public em 1961, publicada no Brasil com o título $A$ representação social da psicanálise, 1878, traduzida da segunda edição francesa, e em 1976, pela presses UniversitaireslFrance, de Paris, na série Bibliotheque Psychanalyse.

A existência de estudos sobre representações sociais é marcada por obras que confirmam a existência desse campo de investigação, tais como Moscovici (1978), Jodelet (1984, 1989), Ibanéz (1988), Doise (1990, 1993), Vala (1993), Sá, (1996), Abric (1994), Wagner e Elezabarrieta (1994).

No Brasil existe um movimento acadêmico voltado para os estudos das representações sociais, que vem se desenvolvendo no sentido de uma familiarização com o seu conceito, análise, crítica e produção científica. Algumas iniciativas desse movimento são as formações de um grupo de trabalho sobre o assunto nos III, IV e V Simpósios de Pesquisa e Intercâmbio Científico da Associação Nacional de Pesquisa e Pós-Graduação em Psicologia (ANPEPP), realizados em 1991, 1992 e 1994 respectivamente (SÁ, 1996). Outra iniciativa constituiu-se na participação de autores 
brasileiros em sessões específicas realizadas em outros eventos científicos, tais como a I Internacional Conference on Social Represetation, em Ravello, na Itália, em 1992; o Congresso Interamericano de Psicologia realizado em Santiago do Chile em 1993; os V, VI e VII Encontros Nacionais de Psicologia Social da Associação Brasileira de Psicologia Social (ABRAPSO) em 1989, 1991 e 1993, respectivamente; o XXIII Internacional Congress of Applied Psichology, realizado em Madrid, Espanha, em 1994; o Encontro de Representação Social do Rio de Janeiro, na Universidade Estadual do Rio de Janeiro (UERJ) em 1994; a $2^{\text {a }}$ Conferência Internacional sobre Representação Social na UERJ, promovida pelo Mestrado em Psicologia, Instituto de Psicologia e École dês Hautes Ètudes em Sociales e a Social Representations Communication Network, que contou com a presença de 46 pesquisadores brasileiros dos diversos estados, dentre os 115 participantes que apresentaram trabalhos (SÁ, 1996 apud SILVA, 2001, p. 24-25).

Moscovici diz que apesar das representações sociais constituírem-se em entidades quase tangíveis, que se cruzam e se cristalizam através da fala, do gesto, do nosso universo cotidiano, existe uma dificuldade de apreensão do seu conceito devido a sua posição "mista" na encruzilhada de uma série de conceitos sociológicos e psicológicos, referindo-se, talvez, às divergências de tratamento do seu objeto nos Estados Unidos e na Europa. No entanto, ele enuncia na sua obra diversos conceitos quando define suas características e funções; quando diz, por exemplo, que nos aproximamos da noção de representação, "quando precisamos sua natureza de processo psíquico capaz de tornar familiar, situar e tornar presente em nosso universo interior o que se encontra a uma certa distância de nós, o que está de certo modo ausente" (MOSCOVICI, 1978, p. 62-63). Diferenciando representação social de imagem, mito e ideologia, ele caracteriza as representações através das seguintes definições:

Por representações sociais entendemos um conjunto de conceitos, proposições e explicações originado na vida cotidiana no curso de comunicações interpessoais. Elas são o equivalente, em nossa sociedade, dos mitos e sistemas de crenças das sociedades tradicionais, podem também ser vistas como a versão contemporânea do senso comum (MOSCOVICI, 1981 apud SÁ, 1996, p. 181).

A representação social é uma preparação para a ação, ela não é somente na medida em que guia o comportamento, mas, sobretudo na medida em 
que remodela e reconstitui os elementos do meio ambiente em que o comportamento teve lugar (MOSCOVICI, 1978, p. 49).

São também importantes iniciativas a publicação de duas obras brasileiras coletivas sobre representações sociais: O Conhecimento do cotidiano - as representações sociais na perspectiva da Psicologia Social, de Bock e Spink (1993) e Textos em Representações Sociais, de Guareschi e Jovchelavitch (1994).

Outra importante iniciativa foi a estada no Brasil de pesquisadores visitantes, a convite do Mestrado em Psicologia da UERJ, dos professores europeus Denise Jodelet, da École de Hautes Études em Sociales: Wolfgang Wagner, da Universitat Linz da Áustria: Jorge Vala, da Universidade de Lisboa, Portugal; Jean-Claude Abric, da Université de Provence, França, e Roberte Farr da London Shool of Economies and Political Science, da Grã-Bretanha, a convite do Mestrado de Psicologia da Pontifícia Universidade Católica (PUC) do Rio Grande do Sul (SÁ, 1996).

Outro evento histórico nas representações sociais no Brasil foi a Jornada Internacional sobre Representações Sociais: teoria e campo de aplicação, realizada em novembro de 1998 em Natal, RN, na qual estive presente, organizada pela Universidade Federal do rio Grande do Norte (UFRN), Universidade Federal do Rio de Janeiro (UFRJ), École de Hautes Études Em Sciences Sociales e Fondation Maison Dês Sciences de L'Homme, com a presença de vários dos pesquisadores mencionados, entre eles Moscovici, Jodelet e Farr. Este evento constituiu-se, na minha avaliação, na culminância dos estudos teóricos e empíricos realizados no Brasil, com a parceria dos pesquisadores precursores desse campo de investigação. A presença de pesquisadores conceituados, junto aos que iniciam investigações nesse campo do conhecimento foi muito significativa, porque deu importantes referenciais para os caminhos que trilhamos na busca de repostas para as nossas questões de investigação.

Moscovici (1978) instituiu como a questão central da sua investigação a forma em "que se converte uma disciplina científica e técnica quando passa do domínio dos especialistas para o domínio comum, como o grande público a representa e modela e porque vias se constitui a imagem que dela se faz" (LAGACHE, 1976 apud MOSCOVICI, 1978, p. 7). A análise de um conceito teórico e abstrato da representação social foi substituída, na 
sua investigação, pela análise de um objeto concreto, a psicanálise, pesquisando a forma como o povo francês a representava.

Durkheim (1978), precursor desses estudos, foi o primeiro a propor a expressão "representação coletiva", localizando o pensar social sobre o individual. Moscovici acrescentou o entendimento de que a representação coletiva não é a soma das representações dos indivíduos que compõem a sociedade e criticou Durkheim por não abordar nem explicar a pluralidade de modos de organização do pensamento social.

A representação social é importante, uma vez que o grande volume de teorias e fenômenos transmitidos na sociedade não poderia ser corroborado na experiência individual. Os significados transmitidos através do conhecimento e realidades diretas são limitados em relação aos conhecimentos e realidades transmitidos através da educação, meios de comunicação e instituições (MOSCOVICI, 1978). Contudo, a representação de uma realidade ou objeto não corresponde à percepção real dessa realidade ou objeto, uma vez que esta tem o papel ativo de modelar o que apreende do exterior e reproduz essa realidade ou objeto, reconstruindo-o. Segundo Moscovici (1978, p. 63), "as representações se constituem para tornar o estranho, o ausente em nós, que nos impressiona, familiar”. Essa percepção que causa estranheza é acomodada pela modelagem, através do repertório de experiência de sua realidade interior. $\mathrm{O}$ objetivo ou ser ausente em nós, ao penetrar no nosso universo, relaciona-se e articula-se com outros objetos que aí encontram, permutando entre si as propriedades daquele e deste, tornando-o próximo e familiar, transformado e transformando os objetos já encontrados, deixando de existir como um objeto, para converter-se no seu equivalente.

Na vida social há situações em que "cada pessoa é uma representação de uma pessoa" (MOSCOVICI, 1978, p. 64), como os filhos dos ricos, dos artistas, etc. e as reações dos indivíduos não são a essas pessoas, mas ao nome e posições que ocupam. Quando se trata de um indivíduo ou grupo estranho, eles não são julgados por si próprios, mas pela etnia, raça, classe ou nação a que pertencem como os judeus, os ciganos, os negros, os pobres, entre outros. Para Moscovici (1978 p. 64) “o racismo é o caso extremo em que cada pessoa é julgada, percebida, vivida, como representante de uma seqüência de outras pessoas ou de uma coletividade".

A representação social é diferente da imagem, esta vista como um reflexo na consciência individual ou coletiva, de um objeto ou feixe de idéias que 
lhes são exteriores, uma fotografia captada e alojada no cérebro, enquanto a representação social é ativa, porque modela e reconstrói o dado do exterior (MOSCOVICI, 1978). Se representação fosse apenas uma imagem, fixaria na consciência individual ou coletiva a imagem da diversidade de papéis e funções do negro na sociedade, a riqueza da sua cultura e religiosidade, entre outras imagens do cotidiano do povo negro, que os objetos recalcadores internalizados na nossa consciência invisibilizam ou modelam negativamente.

A representação social se constitui pelo processo da percepção e internalização de estímulos distantes. No interior do organismo ocorre o processo de construção da percepção ou tomada de consciência do objeto ou da realidade percebida. Para que haja a percepção é necessária a presença do objeto; porém, para a sua conceptualização, a sua presença não é necessária, porque um ser representado à consciência é atualizado, modelado, apesar da sua ausência ou até de uma eventual existência. Dessa forma, a representação de algo pode não ser do objeto inicialmente percebido, mas do objeto construído a partir dos elementos que a ele acrescentamos, no processo de modelagem e reconstrução. Por isso Moscovici considera que as representações sociais constituem-se no senso comum dos indivíduos, elaborado a partir de imagens, crenças, mitos e ideologias. Para ele a representação social é uma preparação para a ação, "ela não é somente na medida em que guia o comportamento, mas sobretudo na medida em que remodela e reconstitui os elementos do meio ambiente em que o comportamento teve lugar" (MOSCOVICI, 1978, p. 49).

Por tudo isso é fundamental em representação social, segundo Moscovici, saber "por que" se produzem as representações sociais, uma vez que a sua função "é contribuir exclusivamente para os processos de formação de condutas e de orientação das comunicações sociais".

Nesse sentido, transformar as representações sociais significa transformar os processos de formação de conduta em relação ao outro representado, bem como as relações com esse outro, porque na medida em que essas representações não apresentarem objetos de recalque, inferiorização ou supervalorização desse outro, a percepção inicial e o conceito resultante dessa percepção, em nossa consciência, terá grande aproximação com o real.

Muitos pesquisadores identificaram o branco como representante da humanidade e da cidadania (HASENBALG, 1979; NEGRÃO, 1986; 
ROSEMBERG, 1980; SILVA, 1995), entre outros. Esse grupo para manter a hegemonia política e econômica construiu ideologias e representações sociais etnocêntricas e hierárquicas, utilizando os aparelhos ideológicos de estado para reproduzi-las. A saturação dessas ideologias e representações converteu-as em hegemônicas e em conseqüência as mesmas foram internalizadas, em grande parte, pelos mesmos e por outros grupos subordinados na sociedade e representados de forma recalcada no livro didático, na mídia, entre outros.

\section{A HEGEMONIA}

A presença do grupo branco enquanto representante da humanidade e da cidadania na nossa sociedade pode ser explicada, em grande parte, pela representação saturada e hegemônica desse grupo nos aparelhos ideológicos do Estado. Ideológica, não concreta, essa representação constitui-se em realidade para a maioria dos sujeitos expostos a essa representação saturada, ou seja, o próprio grupo branco e os demais.

A hegemonia ou supremacia de um grupo social, de uma ideologia, de uma cultura pode ser teoricamente conceituada na tentativa de explicá-la, construindo-se com essas tentativas novos significados, uma vez que a teoria é uma representação, uma imagem um reflexo, um signo de uma realidade que cronologicamente, ontologicamente a precede. A teoria está implicada na produção da realidade. O objeto que supostamente descreve é um produto da sua criação (SILVA, 2000).

Apple (1982) apresenta conceitos de hegemonia de Gramsci e Williams que considero elucidativos do termo. Para Gramsci,

a hegemonia pressupõe a existência de alguma coisa que é verdadeiramente total, que não é apenas secundária, ou superestrutural, como o fraco sentido de ideologia, mas sim que é vivenciada tão profundamente, que satura a tal ponto a sociedade e que, conforme propõe Gramsci, constitui mesmo o limite do senso comum para a maioria das pessoas que se acham sob o seu domínio, que acaba por corresponder à realidade da experiência social de modo muito mais nítido do que quaisquer outras noções derivadas da fórmula de base e superestrutura (APPLE, 1982, p. 14). 
Williams por sua vez define hegemonia como

Todo um corpo de práticas e expectativas: nossas tarefas, nossa compreensão comum do homem e de seu mundo. É um conjunto de significados e valores que, á medida que são experienciados como práticas, apresentam-se como se confirmando reciprocamente. Constitui portanto, um sentido de realidade para a maioria das pessoas da sociedade, um sentido do absoluto, porque experienciados como uma realidade fora da qual é muito difícil para a maioria dos membros de uma sociedade instalar-se em grande parte das áreas de suas vidas (APPLE, 1982, p.15).

Identificar e interpretar teoricamente os processos de saturação que tornam hegemônicas ideologias que promovem a supervalorização de um grupo e o recalque dos demais pode constituir-se em propostas de investigação, com efeitos positivos na educação das relações étnico-raciais.

\section{O BRANQUEAMENTO}

Uma das ideologias identificadas por diversos pesquisadores da questão racial na nossa sociedade é a ideologia do branqueamento. Ela parece ter sido construída por ideólogos transvertidos de cientistas, devido a presença de uma maioria populacional negro/mestiça no país e de um possível conflito a ser gerado a partir da exigência desse grupo dos seus direitos de cidadania e de respeito ás suas diferenças étnico/culturais. Aceitar as diferenças pressupõe atribuir-lhes igualdade de direitos e oportunidades. $\mathrm{O}$ respeito ás diferenças implica numa reciprocidade na igualdade de relações. Como não é possível estabelecer relações recíprocas de direitos e respeito em um sistema baseado na exploração do outro, desenvolve-se ideologias de dominação, objetivando a desconstrução da identidade étnico/ racial/cultural, da auto-estima e do reconhecimento dos valores e potencialidades do oprimido.

A ideologia do branqueamento foi defendida por homens como Joaquim Nabuco, Rui Barbosa e Euclides da Cunha, entre outros. Todos eles eram contrários á escravidão, mas imbuídos do racismo e da inferioridade inata dos negros. Na obra o Abolicionismo Joaquim Nabuco dá uma explicação para o que se pretendia ao abolir a escravidão: "absorver o sangue caucásico vivaz, enérgico e sadio que certamente embranqueceria o nosso povo" (CHIAVENATO, 1986 apud SILVA, 1995, p 26). 
Euclides da Cunha que denunciou o genocídio da população do arraial de Canudos em Os Sertões, apesar de defender o negro e o mestiço os via como desiguais. Em sua obra clássica diz o seguinte:

Intentamos esboçar palidamente embora, ante o olhar de futuros historiadores, os traços atuais mais expressivos das sub-raças sertanejas do Brasil. E fazemolo porque a sua instabilidade de complexo de fatores múltiplos e diversamente combinados aliada às vicissitudes históricas e deploráveis situação mental em que jazem, os tornam talvez efêmeros, destinados ao próximo desaparecimento antes as exigências crescentes da civilização e a concorrência material intensiva das correntes migratórias que começam a invadir profundamente a nossa terra (CUNHA, 1979 apud SILVA, 1995, p. 7).

Afrânio Peixoto, representante da intelectualidade, também expressou o desejo de eliminar o componente negro da nação brasileira. Ele explicita sem dissimulações o ideal do branqueamento, quando diz: "Trezentos anos talvez, levaremos para mudar de alma e alvejar a pele, e se não brancos, ao menos disfarçados, perderemos o caráter mestiço"

Em 1870 chegou ao Brasil o conde de Gobineau, amigo de D. Pedro II e contrário à miscigenação, uma vez que via o miscigenado como um produto degenerado. Como solução para uma degeneração genética, que ele previa se efetivaria no Brasil em menos de 200 anos devido á mistura de raças, pregava a "purificação" com o sangue europeu. Gobineau escreveu que, excluindo D. Pedro II "todo mundo é feio aqui, mas incrivelmente feios: como macacos” (CHIAVENATO, 1986 apud SILVA, 1995, p. 171).

Atribui-se apenas às elites dominantes ganhos com a ideologia do branqueamento aqui implantada. Porém, alguns autores atribuem conquistas para os negros de pele clara, como forma de compensação e justificação para a ideologia. Caste diz a esse respeito que

diferenças mínimas no tom da pele tornaram-se dados sociais significativos. Criou-se assim uma situação em que os favores são distribuídos entre os mestiços na base do seu grau aparente de mistura. Em outras palavras, uma recompensa é atribuída aos graus de branqueamento entre as pessoas de cor (CASTE, 1970 apud HASENBALG, 1979, p. 235).

Porém esses ganhos não podem ser considerados uma vez que o fracionamento da identidade, a auto-rejeição, a rejeição ao seu povo, a negação do racismo aqui existente e a ausência de participação na luta 
pela sua destruição, significam um prejuízo efetivo para a luta por direitos de cidadania e respeito às diferenças.

É importante observar que os brancos pertencentes às classes não detentoras do poder também recebem benefícios com a exclusão do negro na demanda pelo mercado de trabalho, bem como benefícios simbólicos de prestígio e oportunidades na distribuição de bens econômicos e por isso negam que aqui existe o racismo, ao tempo em que expandem as práticas discriminatórias na sociedade.

O desejo de contrapor ao Brasil real pluriétnico e pluricultural um Brasil ideal hegemonicamente branco pode ser observado nas leis de imigração brasileira, que impediam legalmente o ingresso de negros e asiáticos no país. O Decreto de 8 de junho de 1890 dizia que

É inteiramente livre a entrada nos portos da República dos indivíduos válidos e aptos para o trabalho [...] excetuados os indígenas da Ásia ou da África, que somente mediante autorização do Congresso Nacional poderão ser admitidos (NASCIMENTO, 1978, p. 71).

O Decreto-lei n ${ }^{\circ}$ 7.967, de Getúlio Vargas, de 18 de setembro de 1945, regulava a entrada de imigrantes "de acordo com a necessidade de preservar e desenvolver na composição étnica da população as características mais convenientes da sua ascendência européia" (NASCIMENTO, 1978, p. 71).

A ideologia do branqueamento além de causar a inferiorização e a autorejeição, a não aceitação do outro assemelhado étnico e a busca do branqueamento, internaliza nas pessoas de pele clara uma imagem negativa do negro, que as leva a dele se afastarem, ao tempo em que vêem, na maioria das vezes, com indiferença e insensibilidade a sua situação de penúria e o seu extermínio físico e cultural, atribuindo a ele próprio as causas dessa situação.

\section{A BRANQUITUDE E OS PACTOS NARCÍSICOS NO BRASIL}

Iray Carone, professora e pesquisadora do Instituto de Psicologia da Universidade de São Paulo (USP) iniciou em 1992 um estudo sobre os efeitos psicológicos do legado do branqueamento sobre o processo de construção da identidade negra. Essa pesquisa concluída em 1996 intitulou-se $A$ força 
psicológica do legado social do branqueamento - um estudo sobre a negritude em São Paulo (BENTO, 2002).

Outros estudos realizados por Iray Carone (2002), Edith Piza (2002), Maria Aparecida Silva Bento (2002) e Lúcio Otávio Alves Oliveira (2007), entre outros, vêm instituindo na área da Psicologia Social a análise do papel desempenhado pelos brancos na ideologia da branquitude, seus pactos, seus medos, seus silêncios e principalmente, os privilégios conquistados com o recalque e exclusão produzidos na população negra por essa ideologia.

Os estudos sobre branquitude marcam uma nova direção nos estudos étnico-raciais, uma vez que objetivam "abordar as dimensões do que podemos nomear como branquitude, ou seja, traços da identidade racial do branco brasileiro a partir das idéias sobre branqueamento" (BENTO, 2002, p. 25).

O branco pouco aparece no processo de branqueamento. Aparece apenas como o representante da humanidade e modelo universal a ser imitado. $\mathrm{O}$ branqueamento é considerado como "racismo do negro". "É o próprio negro que faz o racismo" diz o senso comum, que por ser transclassista faz aparecer essa expressão na periferia e na academia. A procura de identificação com o branco, a negação dos seus caracteres feno típicos, as tentativas de clarear a pele e ter cabelos lisos as custa da química, do ferro quente, das chapinhas modernas, do alisamento "definitivo", a adoção da sua cultura e do seu comportamento, a rejeição à sua cultura e aos seus assemelhados étnico/raciais não são identificadas como produto da branquitude construída pela elite branca brasileira.

Considerando (ou quiçá inventando) seu grupo como padrão de referência de toda uma espécie, a elite fez uma apropriação simbólica crucial que vem fortalecendo a auto-estima e o autoconceito do grupo branco em detrimento dos demais, e essa apropriação acaba legitimando sua supremacia econômica, política e social (BENTO, 2002, p. 25).

Segundo Bento há um silêncio sobre o lugar que o branco ocupa nas relações sociais brasileiras. O seu papel nas desigualdades sociais não é refletido, nem problematizado. O foco de discussão é o negro, o problema é exclusivamente dele.

Bento identifica "um pacto, um acordo tácito entre os brancos de não se reconhecerem como parte absolutamente essencial na permanência das 
desigualdades raciais no Brasil” (2002, p. 26). Os mesmos atribuem à escravidão a situação atual do povo negro no Brasil.

Assumir a sua ação nas desigualdades impostas pela discriminação racial não é culpabilizar o seguimento branco pelo passado e presente, mas desenvolver o senso de responsabilidade que o mesmo tem para com a situação do grupo negro, para que participe na promoção de ações responsáveis e políticas de ação afirmativa, para que os direitos e oportunidades prevaleçam independentes das diferenças étnico/raciais, entre outras. Diferenças essas que não devem instituir-se de formas hierárquicas e submetidas a recalques na sociedade.

Algumas considerações sobre as etapas concluídas da investigação

A pesquisa corrobora o pressuposto inicial de que o livro didático de Língua Portuguesa de séries iniciais descreve e representa o elemento branco de uma forma hegemônica, idealizada positivamente, contribuindo, em grande parte, para a construção de uma auto estima e identidade étnico racial de representante da humanidade e da cidadania.

Os personagens brancos foram ilustrados e descritos como maioria, com constelação familiar, exercendo os papéis e funções de prestígio na sociedade, com papéis e funções da realeza, como seres divinizados e sem estereótipos. Nos textos receberam nomes próprios, foram adjetivados positivamente, praticaram ações positivas e receberam elogios.

Foram ilustrados apenas uma vez exercendo papel não reconhecido socialmente (ladrão) e duas vezes exercendo função sem prestígio social (trabalhadores braçal).

As categorias de análise pressupõem um maior aprofundamento teórico que permita uma interpretação concreta em sua totalidade. A segunda etapa da pesquisa em processo, constará da análise das categorias à luz da teoria, no sentido de corroborar o papel desempenhado pelas representações do branco nos textos e ilustrações do livro de Língua Portuguesa das séries iniciais, para a construção de um sentimento de superioridade e da branquitude da população branca, bem como apresentando proposta de reflexão para a desconstrução da hierarquia das diferenças étnico-raciais. 


\section{REFERÊNCIAS}

APPLE, Michel. Ideologia e currículo. Tradução de Carlos Eduardo Ferreira de Carvalho. São Paulo: Brasiliense, 1982.

BENTO, Maria Aparecida Silva. Psicologia social do racismo. Petrópolis: Vozes, 2002.

BOCK, Ana Merces Bahia; SPINK, Mary Jane Paris. O conhecimento no cotidiano: as representações sociais na perspectiva da psicologia social. São Paulo: Brasiliense, 1993.

CARONE, Iray. A distância subjetiva entre as classes, de acordo com Aléxis de Tocqueville. In: CARONE, Iray; BENTO. Maria Aparecida Silva (Org.) Psicologia social do racismo. Petrópolis: Vozes, 2002.

GUARESCHI, Pedrinho A.; JOVCHELOVITCH, Sandra. Textos em representações sociais. Petrópolis: Vozes, 1994.

HASENBALG, Carlos. Discriminação e desigualdades raciais no Brasil. Tradução de Patrick Burlin. Rio de Janeiro: Graal, 1979.

MINAYO, Maria Cecília de Souza. Pesquisa social - teoria, método e criatividade. 23. ed. Rio de Janeiro: Vozes, 2004.

MOSCOVICI, Serge. A representação Social da Psicanálise. Tradução de Álvaro Cabral. Rio de Janeiro: Zahar, 1978.

NEGRÃO. Esmeralda. V. Preconceitos e discriminações raciais em livros didáticos e infanto-juvenis. Diagnóstico sobre a situação educacional de negros (pretos e pardos) no Estado de São Paulo. São Paulo: Fundação Carlos Chagas, 1986.

NASCIMENTO, Abdias do. O genocídio do negro brasileiro. Rio de Janeiro: Paz e Terra, 1978.

OLIVEIRA. Lucio Otávio Alves. Expressões de vivência da dimensão racial de pessoas brancas: representações de braquitude entre indivíduos brancos. 2007. 147f. Dissertação (Mestrado em Psicologia) - Faculdade de Filosofia e Ciências Humanas, Universidade Federal da Bahia, Salvador.

PIZA, Edith. O caminho das águas: personagens femininas negras escritas por mulheres brancas. São Paulo: Edusp/Com-Art/Fapesp, 1998.

ROSEMBERG. Fúlvia. Análise dos modelos culturais na literatura infantojuvenil brasileira. São Paulo: Fundação Carlos Chagas, 1980.

SÁ, Celso Pereira de. Núcleo central das representações sociais. Petrópolis: Vozes, 1996.

SILVA, Ana Célia da. O estereótipo e o preconceito em relação ao negro no livro de Comunicação e Expressão de $1^{\circ}$ grau, nível I, Salvador. 1988. Dissertação (Mestrado em Educação) - Universidade Federal da Bahia. 
SILVA. Ana Célia da. A discriminação do negro no livro didático. Salvador: Edufba/Ceao, 1995.

SILVA. Ana Célia da. Desconstruindo a discriminação do negro no livro didático. Salvador: Edufba, 2001.

SILVA, Ana Célia da. As transformações da representação social do negro no livro didática e seus determinantes. 2001. 181f. Tese (Mestrado em Educação) - Universidade Federal da Bahia.

SILVA, T. T. Documentos de identidade: uma introdução às teorias do currículo. Belo Horizonte: Autêntica, 2000. 



\section{Movimentos sociais rurais, quarenta anos depois}

Antônio Dias Nascimento

A abordagem desse tema nos dias atuais, ou seja, quarenta anos depois, exige o esboço de um quadro conjuntural dos anos que antecederam a 1964, como recurso necessário para tornar possível o desvelamento das principais motivações que deram causa aos movimentos sociais do campo naquele período. Esse procedimento, como indicado por Goldman (1988), além de ser uma prática necessária nas Ciências Humanas, uma vez que os problemas sociais devem ser compreendidos dentro do contexto em que se desenvolvem, têm também o sentido de contribuir para facilitar uma melhor compreensão, sobretudo, por parte do público jovem.

Serão privilegiadas aqui, brevemente, nesse quadro conjuntural, três ordens de elementos. A primeira delas está ligada às mudanças econômicas, políticas e sociais, ocorridas no Brasil, a partir de meados da década de 1950, a era do desenvolvimentismo, com ênfase nos seus reflexos sobre a realidade nordestina. A segunda refere-se a uma certa caracterização do pensamento social e político dominante e a concepção que se tinha da questão do campo na época. A terceira diz respeito ao surgimento dos dois principais movimentos sociais camponeses, as Ligas Camponesas e o Movimento Sindical de Trabalhadores Rurais, com ênfase nas suas práticas educacionais. 


\section{O DesenVOLVIMENTISMO no Nordeste}

O período pós Segunda Guerra mundial, no Brasil, foi marcado pela tomada de decisões do Estado no sentido de assegurar as bases necessárias ao processo de industrialização do País. Exemplos dessas medidas foram a construção da Hidrelétrica de Paulo Afonso para a produção de energia elétrica, a implantação de Volta Redonda para a produção de aço, a prospecção, descoberta e instituição do monopólio estatal do petróleo e a conseqüente criação da Petrobras. Outras medidas foram ainda tomadas por Getúlio Vargas na tentativa de colocar o Brasil na rota de um processo de crescimento econômico marcado por um certo nacionalismo.

O alinhamento continental do País com os Estados Unidos, no pósGuerra, foi uma estratégia delineada de fora para dentro e que aqui forjou seus adeptos. Mas a sua aceitação não foi consensual dentro da sociedade brasileira, sobretudo entre os setores de esquerda que arregimentavam as camadas populares e certas camadas do empresariado industrial de base nacional. Talvez os prejuízos que foram impostos ao Brasil pelos vencedores, sobretudo Estados Unidos e Inglaterra, tenham acentuado esse sentimento nacionalista, segundo o qual o País teria de encontrar seu próprio caminho buscando a autodeterminação.

Nesse período, prospera fortemente o populismo implantado e reforçado por Vargas, ao longo dos mais de vinte anos em que marcou a cena política brasileira, seja como regente do poder de 1930 a 1945 e de 1950 a 1954, ou como força latente, no período Constituinte de 1946 a 1950. Para entender-se melhor o populismo implantado por Vargas, é importante lembrarmos a memorável expressão de Antônio Carlos, governador de Minas Gerais naquele período, diante das pressões exercidas pelas classes trabalhadoras durante a República Velha, por melhores condições de trabalho e de vida: "Façamos a revolução, antes que o povo a faça".

De fato, com a implantação paulatina de uma legislação de proteção ao trabalho, inclusive permitindo-lhe a organização sindical, e com uma forte repressão ao movimento sindicalista autônomo - sem a tutela do Estado - ele conseguiu estabelecer o controle do Estado sobre o sindicalismo brasileiro cujas marcas são ainda hoje fortemente perceptíveis. Alguns dos críticos de Getúlio, costumam caracterizá-lo, a partir da análise das suas medidas políticas adotadas, como tendo sido ele "Pai dos pobres e Mãe da 
burguesia”. Esse populismo, no entanto, entra em colapso em 1964 (IANNI, 1975).

A ênfase dos historiadores do período anterior ao desenvolvimentismo recai, comumente, sobre o populismo, caracterizado pela acentuação do papel do Estado como promotor do desenvolvimento capitalista de cunho nacionalista e de uma estrutura política calcada no trabalhismo, caracterizado pela atuação de uma frente política, liderada pelos Partidos Trabalhista Brasileiro, o Democrata Cristão e o Socialista. Esses partidos, por sua vez, abrigavam também representantes de agremiações partidárias clandestinas desde o Governo Gaspar Dutra. Essas representações de esquerda, abrigadas nesses partidos legais, irão desempenhar, mais tarde, papel decisivo no apoio e no desenvolvimento dos movimentos sociais tanto urbanos, como rurais.

Embora algumas medidas, que marcaram essa nova fase da vida nacional, tenham sido tomadas no período Vargas, é ao Governo de Juscelino Kubitischek que a nossa historiografia associa a adesão do Brasil ao desenvolvimentismo. De certo modo, as grandes obras realizadas no governo Kubitischek, como a construção de Brasília em cinco anos, transferindo a Capital da República para o Planalto Central, e a abertura da rodovia BelémBrasília que abriu o caminho para integração territorial da Região Amazônica ao Brasil, assim como a implantação da indústria automobilística no País, acabam por ofuscar as bases para o desenvolvimento lançadas no período anterior, o varguismo.

Dentre as principais conseqüências ocorridas no Nordeste e que vieram aguçar as contradições entre donos de terra - especialmente senhores de engenho - e o campesinato descendente de escravos, brancos empobrecidos e indígenas aculturados, destaca-se em primeiro lugar a demanda pelo aumento da produção de açúcar em decorrência do aumento da renda dos setores operários e outros setores urbanos. Diante dessa demanda, alguns senhores de engenho buscaram reaver as suas terras, até então cedidas, em arrendamento e outras formas de contratos agrários tradicionais, aos seus antigos trabalhadores rurais.

A segunda grande repercussão, desse novo surto econômico, foi a aceleração das migrações de trabalhadores nordestinos em direção ao Centro Sul e ao Centro Oeste do País. No caso do Centro Sul, buscavam trabalho na construção civil, acentuadamente na implantação das novas indústrias, 
e nas lavouras açucareira e algodoeira. No Centro Oeste, por sua vez, eram também fortemente demandados, tanto para a construção de Brasília, como para a abertura das grandes rodovias que ligavam a Nova Capital ao restante do País, sobretudo, a Belém-Brasília.

Um terceiro fato marcante desse período foi a criação do Grupo de Trabalho de Desenvolvimento do Nordeste (GTDN). A liderança desse grupo foi assumida por Celso Furtado. Ao final de alguns anos, com base nos estudos e reflexões realizados sobre o atraso nordestino em relação ao Centro Sul, foram levantadas estratégias com vistas a superar a estagnação da região, sobretudo, no sentido de promover o estabelecimento de condições de vida digna às populações rurais historicamente vitimadas pelas secas. O esforço do GTDN resultou na criação da Superintendência do Desenvolvimento do Nordeste (Sudene), em 1959, - uma agência governamental destinada a estabelecer políticas de desenvolvimento regional.

A criação da Sudene representou um momento histórico de amplas mobilizações sociais, uma vez que, tanto os setores de centro, como os de esquerda a apoiaram. Inclusive a aprovação do Primeiro Plano Diretor foi conseguida através de grandes mobilizações populares no centro de Recife. Todo esse contexto vinha bem ao encontro das expectativas dos técnicos que a conceberam, um vez que eram eles partidários da idéia de que o desenvolvimento é, antes de tudo, social. Daí que, ao lado do estímulo à industrialização, através de incentivos fiscais, as suas primeiras ações foram marcadas também pelo apoio aos diferentes processos de educação popular e à criação de oportunidades para a formação de quadros técnicos voltados para o desenvolvimento (FURTADO, 1964).

Evidentemente que essa consciência, expressa em maio ao aparato do Estado, refletia também a mobilização que fervilhava por toda a América Latina. Também no âmbito da sociedade, vários foram os setores que se manifestavam favoráveis à industrialização do Nordeste e à realização de uma reforma agrária que transferisse não apenas terra aos camponeses, mas também poder, ou seja, condições em pé de igualdade com os demais setores sociais, de participar na definição dos destinos nacionais. Dentre os setores que mais se destacaram estavam a ala progressista da Igreja Católica, parcelas de outras Igrejas Cristãs e organizações de esquerda ligadas a diversas orientações políticas. 
Assim, o período desenvolvimentista se deu, portanto, no embate com fortes mobilizações das classes trabalhadoras, comumente lideradas pela estrutura sindical de base populista e de esquerda, assim como de setores mais politizados das Igrejas Cristãs. A própria Conferência Nacional dos Bispos do Brasil (CNBB), recém criada, embora inspirada em motivações diferentes das motivações da esquerda, manifestava-se vigorosamente em prol de reformas sociais como forma de se superar as condições de estagnação e de miséria que o País vivia. Em particular, no caso do Nordeste, a cúpula da Igreja fez cerrada pressão junto ao Governo Juscelino para assegurar a criação da Sudene.

\section{Pensamento Social E POLítico, DeSENVOLVIMENTISMO E A QUeSTÃo CAMPONESA}

O pensamento social e político do período desenvolvimentista refletia intensamente as questões que norteavam o mundo no pós Guerra. Dentre as várias correntes de pensamento destacam-se, em primeiro lugar, o pensamento conservador que, abertamente, alinhava-se ao pacto intercontinental comandado pelos Estados Unidos, contra o avanço do comunismo. Esse pensamento afirma-se em defesa da propriedade privada, contra as reformas sociais e pela defesa intransigente das instituições estabelecidas pela democracia ocidental. Esse pensamento não era expresso apenas no mundo acadêmico, mas em todas as esferas da sociedade e do Estado.

Entre as ações mais importantes embasadas no pensamento conservador, no sentido de assegurar a resistência a uma possível inclinação do Brasil para o comunismo, foram celebrados pactos militares de âmbito continental, feitos aliciamentos de parlamentares, de membros do governo, realizadas ações junto a universitários, setores religiosos, além da prestação de serviços sociais a setores populares por todo o País e, sobretudo no Nordeste, através dos chamados Voluntários da Paz. Mesmo no campo cultural foram desenvolvidas ações importantes nesse sentido como a produção de filmes, tanto em defesa da democracia americana, como ataques às experiências exitosas do mundo socialista de modo especial a revolução cubana. Viagens de intercâmbio cultural eram promovidas para propiciar a lideranças 
estudantis, operárias e políticas verdadeiras imersões na maravilha americana.

Como base de apoio financeiro sistemático a agências de difusão dessa vertente conservadora de pensamento, foi criado no Brasil, ligado ao Departamento de Estado Americano, o Instituto Brasileiro de Ação Democrática (IBAD). Além de uma revista intitulada Ação Democrática, eram patrocinadas emissões de rádio, programas de TV e peças de jornalismo cinematográfico em geral de caráter alarmista contra o perigo comunista. Os adeptos dessa corrente não viam com bons olhos as ações dos quadros técnicos e políticos que se mostravam favoráveis ao desenvolvimentismo, os que apoiavam os movimentos sociais e as mobilizações de massa pelas reformas de base realizadas em diversos recantos do País.

Em suma, esse pensamento conservador é aqui destacado pela importância que ele assumiu nos episódios que levaram ao colapso, tanto o populismo, como os embrionários projetos de reformas sociais ou mesmo de revolução. Passados quarenta anos, tem-se mais frieza para se olhar o passado histórico e detectar como esse pensamento conservador ganhou robustez e tornou-se capaz de engendrar um projeto de silenciamento à nascente democracia brasileira e ampliou os laços de dominação econômica e cultural do sistema mundial sobre a formação social brasileira.

Uma segunda expressão que compôs o arcabouço do pensamento social e político à época do desenvolvimentismo foi ligada à democracia cristã e à social democracia. Em síntese, a democracia cristã inspirava-se na Doutrina Social da Igreja Católica, expressa através das Encíclicas Papais Rerum Novarum, Quadragessimo Anno, Mater et Magistra, Pacem in Terris e Populorum Progressio. Essa corrente reconhecia a exploração dos trabalhadores pelo capital, mas propunha o diálogo entre empregadores e empregados, senhores de terra e camponeses como forma de superação dos conflitos. Pressionavam os aparatos do Estado para que intermediassem os conflitos sociais, através das negociações e não da repressão.

A democracia cristã, no contexto anterior a 1964, chegou a ter influentes representantes na esfera federal. Suas bases, embora estivessem pulverizadas por todo o País, seus maiores contingentes encontravam-se no Sul e CentroSul do País. A social democracia, por sua vez, inspirava-se na social democracia alemã que se baseava no fortalecimento da democracia pela liberdade expressão dos diversos setores da sociedade. Também como a 
democracia cristã, defendia inclusive a participação dos trabalhadores nos lucros das empresas. Essa corrente se expressava através de empresários representantes de setores da burguesia de caráter nacionalista e pelo trabalhismo fortemente embasado no sindicalismo.

De certo modo, essa aliança entre social democracia e democracia cristã, conseguiu firmar uma sólida liderança política e obteve importantes conquistas para a organização dos trabalhadores destacando-se, dentre as principais, o pagamento do décimo terceiro salário a todos os trabalhadores, a sindicalização dos trabalhadores rurais e a extensão da legislação trabalhista ao campo. Apesar de suas posições políticas moderadas, essa frente também foi alvo da conspiração dos setores conservadores. Frequentemente, eram acusados pelos conservadores de fazerem frente única e de serem coniventes com os comunistas.

Uma terceira corrente de pensamento definia-se em torno de ideais revolucionários de diferentes matizes. Seus adeptos mais antigos surgiram, embrionariamente, ainda nos anos de 1920, quando se orientavam por uma certa ortodoxia doutrinária. Viam na formação social brasileira um caráter dominantemente feudal, pois não se via por aqui uma sociedade civil independente dos interesses agrários e, muito menos, um Estado nacional fundado em bases iluministas. Enxergava-se, de certo modo, os ideais de liberdade, igualdade e fraternidade que, de certo modo, influenciaram a formação da República no Brasil, como retórica dos senhores feudais no poder.

Reforçavam ainda esse pensamento o fato de vigorarem, ainda no campo, os contratos agrários como meação e outras formas de parceria como heranças medievais e como expressões evidentes do feudalismo. Desse modo, os camponeses eram vistos como forças reformistas, ou seja, sem o necessário vigor revolucionário característico da vanguarda operária. Assim, numa perspectiva estratégica, os camponeses eram vistos mais como aliados importantes. Acreditavam que as reivindicações camponesas poderiam ser atendidas pelo Estado burguês através da reforma agrária e da introdução da legislação trabalhista no meio rural.

Outras vertentes mais recentes, inspiradas em outros processos revolucionários, posteriores à Revolução de 1917, como a Revoluções Chinesa e Cubana, aliavam-se ao processo latino americano, ou seja, não sendo a América Latina uma região industrializada, não se dispunha, 
consequentemente, de uma vanguarda operária suficientemente forte para assumir a direção revolucionária. Neste caso, eram fortemente revividos os ideais de Simon Bolívar, sobretudo diante do triunfo da Revolução Cubana em janeiro de 1959, apoiada no campesinato.

Esses setores de esquerda acreditavam no potencial revolucionário do campesinato. O mais expressivo movimento camponês ligado a essa esquerda foi a Liga Camponesa que, nascida da resistência de meeiros em deixar suas terras, lutavam por uma "Reforma Agrária na Lei ou na marra". (AZEVEDO, 1982). Identificavam uma forte aliança entre o imperialismo norte americano e o latifúndio no Brasil contra a qual se organizava uma aliança operário-estudantil-camponesa. Ainda em 1961, realizaram um Congresso em Belo Horizonte, onde destacavam como uma das reivindicações principais ao Governo Federal a investidura sindical das Ligas Camponesas. Nesse aspecto eles se opunham não apenas à presença americana no Brasil e na América Latina, como também às alas progressistas da Igreja, à Social Democracia, e a Democracia Cristã aos quais denominavam de reformistas.

\section{PRÁTICAS EDUCACIONAIS DOS MOVIMENTOS SOCIAIS CAMPONESES ATÉ 1964}

Assim como foram vários os movimentos sociais camponeses, também foram diferentes as suas práticas educacionais. Todas elas tinham em comum o reconhecimento do estado de opressão em que viviam tanto os camponeses, ou seja, aqueles que detinham a posse precária da terra ou mesmo que possuíam pouca terra, assim como os assalariados. Nem sempre foi uma questão pacífica para cada um dos movimentos dar conta de sustentar as duas frentes de luta: a da permanência na terra, ou a luta pela terra e pelo salário.

Aqui serão tecidas considerações sobre os processos educacionais assumidos pelos dois movimentos que ganharam maior notoriedade - a Liga Camponesa e os Sindicatos de Trabalhadores Rurais. A literatura especializada não se refere a um processo educacional, propriamente dito, característico da Liga Camponesa. Melhor seria, talvez, reportarmo-nos a uma prática política calcada na mobilização de massas. Identificava-se claramente os dois inimigos fundamentais da sociedade brasileira que eram 
o latifúndio e o imperialismo e contra eles fazia-se um intensivo trabalho de denúncia na expectativa de estimular a justa ira contra a opressão.

A primeira grande palavra de ordem era a necessidade de organização em defesa da luta pela terra desde o seu começo nos meados dos anos de 1950, até a sua extinção pelo movimento militar. Contudo, as estratégias dessa luta foram sendo alteradas, na medida em que prosperavam as disputas, dentro Partido Comunista Brasileiro (PCB), que, majoritariamente, não aceitava a principalidade do campesinato no processo revolucionário. Para a maioria dos membros do $\mathrm{PCB}$, quem detinha a função de vanguarda era o operariado.

Com o triunfo da Revolução Cubana, baseada na luta do campo para a cidade, como visto anteriormente, contrariando a ortodoxia do PCB, segundo o qual a Revolução liderada por Fidel Castro e Che Guevara estaria queimando etapas. A partir de então, sobretudo depois da invasão da Bahia do Porcos pelos Estados Unidos e da Proclamação da II Declaração de Havana, reforça-se, dentro da Liga Camponesa, a idéia de organizar-se militarmente para intensificar a luta em prol do socialismo o que, segundo alguns autores, a teria levado ao isolamento de importantes setores sociais de esquerda, seus potenciais aliados.

Assim, diferentemente de reuniões em ambientes fechados, as práticas educacionais da Liga Camponesa se davam no enfrentamento aberto com o latifúndio, nas mobilizações de grandes massas nas capitais do Nordeste e mesmo em outros centros urbanos menos importantes. Embora a grande massa camponesa fosse, em sua maioria iletrada, era feita a distribuição massiva do jornal A Liga, cuja temática dominante era a defesa da Reforma Agrária Radical, ou seja, a extinção pura e simples do latifúndio sem indenizações como preconizava o PCB de então.

Eram também largamente utilizados os cordéis, abordando os vários aspectos da exploração sofrida pelos camponeses e estimulando-os a aderirem à luta contra o latifúndio, através da Reforma Agrária Radical. A formulação de palavras de ordem era um recurso didático também fortemente utilizado. Dentre essas as mais recorrentes podem ser lembradas: “Reforma Agrária na lei, ou na marra!”, ou ainda, "Camponês sem terra, Operação sem Pão, é barriga vazia, tambor de revolução, viva a Reforma Agrária Radical, com Francisco Julião”. 
No que pese todo o altruísmo que se tinha em ajudar os camponeses a se libertarem da opressão em que viviam sob o peso do latifúndio, o que se buscava afirmar nos corações e mentes era o sentido de classe explorada e cuja tarefa histórica a desempenhar era a derrubada do latifúndio e do imperialismo. Não havia, portanto um processo educacional no sentido de contemplar os indivíduos na sua inteireza. A ênfase dada, na verdade, era à dimensão social e, sob este aspecto, não caracterizava, na ação da Liga Camponesa uma ação educacional propriamente dita, dado ao seu caráter homogeneizador (MEDEIROS, 1989; MARTINS, 1981).

Todavia, não se pode falar de uma orientação única da Liga Camponesa, pois, além de ter divergido da orientação central do PCB, ela não conseguiu manter a unidade dentro do próprio movimento. Assim, praticamente, em cada Estado, havia uma conduta política própria. Nos Estados do Pernambuco e Paraíba, porém, ela conservava características similares. O Partido Comunista do Brasil, por sua vez, passou a fundar sindicatos de trabalhadores rurais por acreditar que, considerando o caráter da revolução brasileira, os camponeses deveriam ser orientados nos sentido de reivindicar direitos trabalhistas, liberdade de organização sindical e uma reforma agrária dentro da Lei.

Nesta linha da sindicalização rural também atuavam, em sua maioria, os setores progressistas da Igreja Católica. Entre outras, talvez a diferença básica, entre a atuação do PCB e Igreja, residisse no fato que o partido fundava os sindicatos como mecanismo de angariar adeptos, enquanto que, em relação à Igreja, o que se percebia era a preservação da ordem, diante do entendimento de que a ordem liberal também comportava a extensão dos direitos trabalhistas sem que necessariamente se tivesse que passar por uma revolução socialista.

Equivocadamente, alguns autores como Azevedo (1982), associam o trabalho de sindicalização da Igreja Católica, com a posição extremamente conservadora dos Arcebispos de Diamantina, em Minas Gerais, Dom Geraldo de Proença Sigaud, e Dom Antônio Castro Mayer para os quais, cometeria um sacrilégio, pecado grave, aquele que recebesse um pedaço de terra que tivesse sido expropriado pelo Estado. Sob as bênçãos desses Bispos foi criada no Brasil a Sociedade Tradição, Família e Propriedade, liderada por Plínio Correia de Oliveira. 
As Dioceses mais importantes do Nordeste, à época, justamente em direção oposta aos Bispos Sigaud e Mayer, destacando-se em especial as de Recife e Natal, criaram organismos ligados à estrutura diocesana para cuidarem da formação de lideranças trabalhadoras rurais, tanto a cerca de seus direitos como cidadãos, como direitos trabalhistas, além da organização sindical. Evidentemente que muitos dessas lideranças, as primeiras, sobretudo, foram recrutadas dentre os membros das organizações religiosas de leigos, mas com a ampliação dos quadros formados, como conseqüência do efeito multiplicador, muitos outros trabalhadores também foram tendo acesso ao que se denominou de educação sindical.

Os trabalhadores eram convidados para fazerem um curso em regime de internato, geralmente por um fim de semana, para que não chamassem tanto a atenção dos senhores de engenho seus patrões. Esses cursistas recebiam passagens de ida e de volta, alimentação três vezes ao dia durante o curso, como não costumavam ter em seus cotidianos, dormida e, por fim, eram ressarcidos, à custa dos promotores dos cursos, pelos dias que passassem em estudo. Nos primeiros cursos, costumava-se dar preferência a candidatos que já soubessem ler porque eles também podiam levar material didático para ler e explicar aos seus companheiros.

Todos os cursos começavam por um levantamento da situação de exploração em que viviam os participantes, tais como a jornada de trabalho, comumente bem superior às oito horas diárias, ausência de salários definidos, e a inexistência de uma organização representativa de seus interesses que pudesse defendê-los. Em seguida, além de ouvirem explicações sobre os direitos, participavam de diferentes dinâmicas organizadas de tal modo a despertar reflexões nos participantes sobre temas fundamentais no processo de organização que se queria estimular, tais como a importância de os trabalhadores estarem unidos em torno de um sentido comum, a força da união de todos no sindicato contra o latifúndio.

A programação dessas jornadas de formação era também integrada por momentos de recreação e integração, através dos quais, cada um era estimulado a aprender os nomes dos demais companheiros, revelar seus dotes artísticos, como a criação de repentes, declamação de poesias, contar histórias, cantar alguma canção, dançar, tocar o violão, o acordeom, ou mesmo a percussão e outros instrumentos usuais entre os camponeses. Além disso, entre as dinâmicas realizadas havia um momento especial para serem 
aprendidos cantos de conteúdo exortativo à união dos camponeses contra a espoliação dos patrões, em prol da reforma agrária e outros temas que, em momentos posteriores, de mobilização em marchas pelas ruas das cidades, eram cantados por todos em uníssono (NASCIMENTO, 1993; 1985).

Esse trabalho de educação sindical foi também muito reforçado pelo Movimento de Educação de Base (MEB), sistema de educação à distância, realizado através de transmissões radiofônicas. Esse movimento era também ligado à Igreja Católica e contava com um certo suporte do governo populista. Esse processo educacional, embora começasse pela formação de lideranças trabalhadoras rurais, na continuidade, chegava-se à organização dos Sindicatos de Trabalhadores Rurais em diferentes municípios. Nesse momento, havia uma verdadeira corrida contra a ação do PCB, para ver quem conseguia chegar primeiro junto aos trabalhadores em cada município.

Era fato comum os trabalhadores não perceberem a diferença entre os sindicatos orientados pela Igreja e aqueles orientados pelo PCB. Ambos pautavam-se pela conquista da legislação trabalhista para o campo, pelo fortalecimento da classe trabalhadora e pela reforma agrária. Tanto as cúpulas da Igreja como do PCB, embora se digladiassem nos debates públicos nas universidades e em centros de estudos, não conseguiam fazer chegar essas divergências às bases. Isso se evidenciava, de modo especial, nos momentos de encaminhamento dos movimentos reivindicatórios, quando todos marchavam unidos. Aos poucos, no entanto, essas divergências foram-se tornando conscientes pelas lideranças de base, tendo chegado, em muitos casos, também aos trabalhadores.

Enquanto o trabalho educacional da Igreja era realizado em grupos menores, o trabalho de educação do PCB, para os trabalhadores rurais, guardava uma certa semelhança com o trabalho das Ligas. Apelava-se muito para as concentrações onde eram feitos os discursos e as proclamações sobre a legislação, sobre o sindicato e sobre a perspectiva revolucionária onde todos seriam reconhecidos como cidadãos. Desse modo, pode-se perceber que o trabalho educacional da Igreja dirigia-se muito mais aos indivíduos em particular na expectativa de que estes, uma vez conscientizados e politizados, comunicassem também essa nova consciência aos seus companheiros alfabetizados ou não. 
O trabalho educacional da Igreja para os trabalhadores rurais não se restringia apenas aos camponeses. Havia também uma preocupação em formar quadros técnicos que pudessem assessorar as organizações sindicais em suas demandas cotidianas e no exercício da representação dos trabalhadores fossem eles associados, ou não, aos sindicatos. Além de advogados que se dispunham a atuar junto à militância sindical, também estudantes universitários de diferentes áreas e até mesmo secundaristas se dispunham a apoiar esses sindicatos em suas diferentes tarefas.

Esses voluntários, comumente, eram ligados à Ação Católica, movimento de leigos por um mundo melhor, nascido na França, que se inspirava na Doutrina Social da Igreja. No caso do Brasil, teve significativa atuação no meio da juventude onde conseguiu formar importantes lideranças políticas para as lutas futuras. Um dos grupos de jovens organizados dentro da Ação Católica foi a Juventude Agrária Católica (JAC) que também muito contribuiu para a formação de lideranças no meio rural. Assim, embora se tenha tornado habitual entre os militantes remanescentes e os memorialistas falar-se mais do trabalho desenvolvido pelos organismos diocesanos e, posteriormente, pelo próprio movimento sindical de trabalhadores rurais, a ação educativa foi assumida de forma difusa e cooperativa por vários setores progressistas da Igreja.

Ao perceber como proliferavam os sindicatos de trabalhadores rurais por todos os lados, tornou-se fato digno de registro o apelo realizado por Francisco Julião à união de todos os camponeses. Numa tentativa de recuperar a união dos trabalhadores do campo em torno da Liga Camponesa, Julião lançou uma carta aos camponeses, intitulada "A bênção, mãe Liga”, onde ele argumentava que o sindicato era filho das Liga e, consequentemente, o filho não podia brigar com a mãe, nem a mãe com o filho. Em sendo assim, portanto, todos os membros da Liga deveriam associar-se ao Sindicato e todos os membros do Sindicato deveriam associarse à Liga.

Assim, os meses que antecederam ao golpe militar de março de 1964 em Pernambuco, pelo menos, foram marcados pela realização de assembléias camponesas onde as diretorias sindicais de orientação católica foram destituídas e, em seus lugares, foram empossadas diretorias compostas por militantes da Liga Camponesa. Desse modo, praticamente todos os sindicatos da Zona da Mata de Pernambuco foram transformados em 
representantes oficiais da Liga e foi, justamente nessa condição, que o golpe militar os alcançou. Todos os sindicatos foram fechados, muitas lideranças foram presas, outras evadiram-se para destinos ignorados. Passados os primeiros momentos de instalação da nova ordem, no entanto, a Igreja Católica assumiu a responsabilidade política juntos aos militares pela criação dos sindicatos e, aos poucos, foi-se restaurando a normalidade administrativa dos sindicatos através de Juntas Governativas, nomeadas pelo Ministério do Trabalho, por indicação dos organismos diocesanos. Nos anos seguintes essa posição foi a causadora do estremecimento entre o Movimento Sindical e esses setores da Igreja Católica e desta com outros setores progressistas.

Em conclusão, pode-se dizer da efetividade desse trabalho educacional, realizado junto aos camponeses e trabalhadores rurais realizado por diferentes correntes ideológicas. Embora não se tenha eliminado, por inteiro, o sistema de exploração estabelecido no campo desde os primórdios da colonização brasileira, a história recente tem registrado como os camponeses, apesar de todos os reveses e baixas sofridos, têm-se insurgido contra a opressão. Apesar de toda a repressão que se abateu sobre o movimento camponês, enquanto categoria social, ao longo desses quarenta anos, ele ressurge em outras formas de expressão.

Definitivamente, os movimentos do campo se inscreveram na cena política nacional, tanto como atores sociais importantes, marcando com suas presenças as diferentes conjunturas, assim como sendo portadores de experiências de mobilização, organização e de conquistas sociais capazes de servirem de motivação a outros setores sociais que ainda sobrevivem sob novas formas de opressão seja no campo, ou nas cidades, engendradas pela ordem moderna.

\section{REFERÊNCIAS}

AZEVEDO, F. A. As Ligas Camponesas. Rio de Janeiro: Paz e Terra, 1982. FURTADO, C. Dialética do Desenvolvimento. Rio de Janeiro: Fundo de Cultura, 1964.

GOLDMAN, L. Ciências Humanas e Filosofia. O que é Sociologia? 11. ed. Rio de Janeiro: Bertrand Brasil, 1988.

IANNI, O. O Colapso do Populismo no Brasil. 2. ed. Rio de Janeiro: Civilização Brasileira, 1975. 
. Origens Agrárias do Estado Brasileiro. São Paulo: Brasiliense, 1984.

JULIÃO, F. Escucha Campesino. México: Extemporâneos, 1971.

MARTINS, J. S. Os Camponeses e a Política no Brasil. Petrópolis: Vozes, 1981.

MEDEIROS, Leonilde Sérvolo de. História dos Movimentos Sociais no Campo. Rio de Janeiro: FASE, 1989.

NASCIMENTO, A. D. Peasant Social Movements and Rural Workers' Trade Unions in Bahia (1972-1990). PhD Thesis. Liverpool: Liverpool University, 1993.

- Organização de Base: a reinvenção da participação popular. Salvador: FFCH - Universidade Federal da Bahia, 1985. 



\title{
O projeto pedagógico do MST: a experiência em escolas de Vitória da Conquista
}

\author{
Rosana Mara Chaves Rodrigues
}

As condições históricas que resultaram no surgimento do Movimento dos Trabalhadores Sem Terra (MST) levaram-no ao estabelecimento de um amplo projeto de enfrentamento a ser empreendido na ordem estrutural do País, na expectativa de eliminar as condições de reprodução da miséria, da dominação e da exclusão dos trabalhadores rurais, através de um conjunto de ações concretas. Estas ações, por sua vez, estão materializadas em projetos de desenvolvimento local e de mobilizações local, regional e nacional, no sentido de reunir o necessário apoio da sociedade civil e ampliar seu nível de consciência quanto à necessidade e à urgência das transformações propostas além de levar o aparato do Estado a estabelecer canais de negociação que tornem possível a implementação das ações a fim de que ocorram as mudanças preconizadas.

Essas propostas são concebidas em plano nacional, com sua materialização no local, nos assentamentos, o que estabelece e revela necessariamente um caudaloso manancial de possibilidades de negociação, de tensões, resistências e mudanças, cuja análise pode oferecer elementos importantes para a construção de um conhecimento voltado para o entendimento dos processos de modificações em diferentes áreas, seus alcances e seus limites e de como se montam as estratégias, tanto para a 
obtenção das mudanças pelos oprimidos, como para a resistência pelos setores dominantes.

Embora a análise desse amplo processo de enfrentamento entre resistência e mudança, que vem sendo levado a efeito pelo MST nas mais diversas regiões do País, possa se apresentar sob variadas perspectivas, o presente estudo volta-se, especificamente, para avaliar a implementação da proposta pedagógica do MST para as escolas dos assentamentos.

Esta pesquisa parte do princípio de que a produção do conhecimento acontece na relação mútua de troca entre o pesquisador e o pesquisado, pois ambos possuem saberes que se complementam. Dessa forma, o objeto de pesquisa não está dado por inteiro, a priori, mas é construído nessa relação.

Por se tratar de um Movimento, a pesquisa de campo foi permeada por duas tensões: de um lado, a própria natureza do objeto que se constitui em um objeto em movimento, e do outro, a dificuldade de penetração numa organização que, apesar de estar aberta a receber pesquisadores, o recebimento é feito com certos critérios o que impõe certos limites ao desenvolvimento do estudo. Para enfrentar essas tensões, procurou-se através das observações registrar a forma como o objeto se apresentava a cada visita, como também construir uma relação de confiança com o grupo. Esta relação foi fundamental para que a pesquisa se desenvolvesse com êxito. Considerando a complexidade do tema abordado e os limites inerentes ao presente estudo, a metodologia foi sendo definida a partir do contato estabelecido com os sujeitos da pesquisa em cada visita realizada.

Portanto, para apreender os aspectos relevantes de resistência e mudança que emergem do confronto entre uma proposta educativa que se pretende libertadora e inclusiva, e a realidade local estruturada segundo os padrões sociais e culturais que tendem a reproduzir a condição de dependência e de submissão e exclusão dos sujeitos, decidiu-se pelo Estudo de Caso. Justificase a escolha porque este método permite o estudo realizado em uma realidade dinâmica, e, através do contato direto com os sujeitos da pesquisa, é possível desvelar os encontros e desencontros que permeiam o dia-a-dia da prática escolar e da comunidade que abriga a escola. Permite, também, chegar bem perto da escola e da comunidade para entender como operam, no seu dia-a-dia, a proposta de educação do MST, suas ações, relações, retrações e interações, apreendendo as forças que a impulsionam ou que as retêm, as resistências e as mudanças. 
De acordo com Ludke e André (1986), o estudo de caso, enquanto abordagem de pesquisa permite uma apreensão profunda e ao mesmo tempo ampla e integrada de uma unidade social complexa, considerando suas múltiplas dimensões e sua dinâmica natural, e para isso requer um intenso trabalho de campo, ou seja, contato direto e prolongado do pesquisador com a situação investigada.

A pesquisa foi realizada entre os anos de 1999 e 2002, tempo em que se visitou a região por sete vezes, com permanência de, ao menos, uma semana a cada visita, o que resultou no mínimo 280 horas de observação nos locais investigados. Nestas visitas, buscava-se estar sempre em contato com as escolas, professores, alunos e comunidade, seja em reuniões, cursos ou realizando os trabalhos escolares, o que possibilitou a realização de entrevistas, conversas informais, observação direta do cotidiano e coleta de materiais produzidos pelos alunos e professores.

Como instrumentos de pesquisa, lançou-se mão de entrevistas semiestruturadas conversas informais, observação com registro em diário de campo e coleta de materiais produzidos pelos alunos.

O referencial teórico esteve orientado no sentido de buscar compreender o MST e seu processo de produção do projeto pedagógico para escolas de assentamentos rurais. Ao analisar a proposta de educação do movimento, identificou-se que se encontra, entre seus princípios, categorias pensadas por Gramsci (1981), a exemplo de escola formativa, intelectual orgânico e cultura, ou seja, a idéia de escola como espaço de transformação e de Freire (1987), sobretudo os que tratam de educação bancária e educação libertadora. Ao lado dessas categorias, parte-se do pressuposto de que, na base do MST e também da escola concebida pelo movimento, encontra-se a idéia de utopia, enquanto um horizonte que impulsiona a luta. Portanto, na base deste trabalho, a utopia será retomada pela necessidade de redefinila na contemporaneidade.

\section{O MST COMO UM “NOVO” MOVIMENTO SOCIAL}

Inúmeras e rápidas transformações estão-se processando no seio da sociedade em decorrência da globalização tecnológica e informacional nas últimas décadas. Para alguns teóricos, a globalização se apresenta “[...] como a intensificação das relações sociais em escala mundial, que ligam 
localidades distantes de tal maneira que acontecimentos locais são modelados por eventos ocorrendo a muitas milhas de distância e viceversa" (GIDDENS, 1991, p. 69).

Para outros, a globalização se apresenta como um movimento estrutural do capitalismo - uma fase em que as principais tendências, já presentes desde os primórdios, são levadas as suas últimas conseqüências, desenvolvese no seu limite, sendo, portanto um novo momento histórico no interior do sistema capitalista (DRUCK, 2000).

Ainda para Druck, (1996, p. 24), “[...] a globalização representa as linhas mais gerais de radicalização do homem racional e produtivo produtor de mercadorias". Nesta perspectiva, a globalização traz consigo inovações no âmbito econômico e político. No econômico, a transnacionalização do capital e dos investimentos num mercado "sem fronteiras". No político, a constituição de uma articulação de centros de poder global, o Grupo dos Sete (G7), Fundo Monetário Internacional (FMI) e o Banco Interamericano de Reconstrução e Desenvolvimento (BIRD). Apresenta as seguintes características: concentração, centralização e dispersão de capitais; transnacionalização; superdimensionamento da esfera financeira (a lógica financeira se sobrepondo à lógica produtiva); reforço do poder dos bancos como instituições financeiras; a reestruturação do Estado e a intervenção governamental; a redefinição das relações de poder entre os países centrais e periféricos e, em especial, a rapidez do tempo social em que ocorrem as transformações: informatização, redes de comunicação mundial, definição e intervenção simultâneas de um lado a outro do planeta. Enquanto, no século XIX, transformações que revolucionaram a sociedade eram fruto de até 2 ou 3 séculos, no século XX, transformações mais profundas ocorrem em décadas. Conforme analisa Hobsbawn, (1995, p. 13).

A destruição do passado - ou melhor, dos mecanismos sociais que vinculam nossa experiência pessoal à das gerações passadas - é um dos fenômenos mais característicos e lúgubres do final do século XX. Quase todos os jovens hoje crescem numa espécie de presente contínuo, sem qualquer relação orgânica com o passado público da época em que vivem. Por isso os historiadores, cujo ofício é lembrar o que os outros esquecem, tornam-se mais importantes que nunca no fim do segundo milênio.

Nesse contexto, vão surgindo os "novos" movimentos sociais, que são chamados assim porque apresentam algumas diferenças fundamentais em 
relação aos movimentos tradicionais ou clássicos e, em especial, em relação ao movimento operário (SCHERER-WARREN, 1996). Ainda como reflete Maria da Glória Gohn (2002, p.12):

Os novos movimentos sociais (ecológico, ambientalista, pela paz, direitos humanos, das mulheres, negros, índios e tantos outros) colocaram na agenda da sociedade novos valores e transformaram o lugar que a sociedade lhes reservara tradicionalmente. Transformaram-se em sujeitos, saíram das margens e bordas do social e migraram para o centro, tornando-se fonte de criatividade e de referência. Criaram e desenvolveram identidades culturais e políticas a partir da constituição de redes; inovaram ao construir novos valores e significados novos aos já existentes, reformularam as formas de atuar e de interagir na sociedade. Produziram o que se constitui um dos pilares da práxis humana: conhecimentos, novos conhecimentos. Por isso, os movimentos sociais têm sido vistos como fontes de inovação, revitalização das energias do social.

Para a autora, a novidade é que a grande força impulsionadora dos processos sociais não advém somente da política, ou da reação/resistência aos mecanismos de privação socioeconômica, mas também da cultura, pois raízes culturais têm sido resgatadas, não para cultuar a memória de um passado, mas para dar amálgama a práticas novas.

O MST surge nesse contexto trazendo para a ordem do dia um velho tema - a Reforma Agrária.

A posse da terra, embora seja o objetivo imediato desse grupo social, vem acompanhada de outras lutas como, por exemplo, pelos direitos sociais e pela conquista de uma sociedade justa, o socialismo. Para atingir os seus objetivos, o MST toma a educação como um direito indispensável que se desenvolve como um processo que inclui a educação formal - fundamental, médio e superior - e informal, realizada a partir da participação dos sujeitos nas mobilizações organizadas pelo MST através das marchas, ocupações e manifestações outras, incluindo, nesse processo, todas as gerações: crianças, jovens, adultos e os gêneros.

Assim, compreende-se que a trajetória do MST, desde o seu nascedouro, assume formas diferenciadas nos diversos espaços onde ele se materializa e a força impulsionadora desse movimento é a sua utopia, que renasce a cada conquista dos trabalhadores Sem Terra. 


\section{EDUCAÇÃO, UTOPIA E TRANSFORMAÇÃO}

Pensar a utopia do MST nos remete a concepção defendida pelo filósofo alemão Ernst Bloch que retoma esse conceito, atribuindo-lhe um sentido singular. A utopia em Bloch (1970) na sua obra O Princípio da Esperança assume um caráter de possibilidade, conquista, perspectiva de transformação social. Forja, portanto, um conceito de "utopia concreta".

Para entender a concepção bloquiana de utopia, é necessário tomar alguns pontos básicos da sua análise sobre as raízes antropológicas do princípio da esperança.

O que orienta o seu pensamento é o princípio da esperança, o qual é tomado não apenas como uma diretriz, mas como a causa da ação, uma fonte da práxis. Bloch (1970) distingue uma primeira raiz da esperança, que é o fato comum de o homem ter consciência de que tem fome, assim a carência do homem é o que lhe garante a consciência de que tem fome e do que lhe falta.

Quando um homem tem fome, esta necessidade fisiológica imediata e constrangedora não é recebida com indiferença, mas projeta o homem para fora da sua indiferença, provocando o acordar da sua consciência. Este acordar não só padece de necessidades, mas que tem consciência de ter necessidade (BLOCH, 1970 apud FURTER, 1974, p. 80).

A necessidade, portanto, é o que faz despertar, no homem, a consciência, da carência e da insatisfação, o que impulsiona o movimento de satisfação da carência, e nesse movimento é feita à exploração do possível. Em síntese, a fome gera a consciência da carência que faz emergir a possibilidade de atuar para passar da carência a algo desejado, a satisfação.

A fome, embora seja uma sensação individual, leva a um projeto coletivo porque, segundo Bloch, “ [...] a comida visada poderia ser consumida por um outro e, no mundo da escassez em que vivemos, esta ameaça do outro existe violentamente" (BLOCH, 1970 apud FURTER, 1974, p. 81). Ao refletir sobre essa reação, pode-se imaginar que o outro em vez de ameaçar o que quer, o alimento desejado, poderia dividi-lo: daí a idéia de uma organização social, mais ainda poderiam unir-se para produzirem mais ou trocarem os excessos.

Porém não existe só uma fome física, há também outras fomes: afetivas, sentimentais, eróticas, intelectuais. E “[...] o conjunto destas fomes pode 
ser caracterizado como o desejo, sendo a vontade humana de ir além que faz crescer, desenvolver e aumentar as dimensões do homem" (BLOCH, 1970 apud FURTER, 1974, p. 82) o que já indica o que estar por vir, o homem como inacabado, como tendência para ser outro e para ser mais.

Além da fome e dos desejos, os sonhos acordados são fatos elementares onde se enraíza a esperança. Nas palavras de Bloch:

O sonho acordado manifesta uma verdadeira fome psíquica pelo qual o homem imagina planos futuros e outras situações em que supere os problemas, as dificuldades e as obrigações de um hoje onipresente. Assim os sonhos acordados nos dão uma primeira forma tosca, vaga, talvez ilusória, do que será, numa fase mais elaborada, a utopia. Nos sonhos, une-se pela primeira vez o que será decisivo para a constituição de uma consciência antecipadora: a consciência da fome, e o possível imaginário: os desejos e as imagens (1970 apud FURTER, 1974, p. 83).

São os sonhos acordados que nos impulsionam para o futuro, ao contrário dos sonhos noturnos, que se gastam no inconsciente. Nos sonhos acordados, a reflexão é imediatamente possível.

No entanto, a capacidade de sonhar, de aspirar e de esperar, ainda que seja inerente aos homens, pode sucumbir quando as condições econômicas, sociais e culturais lhes faltem em demasia, pois podem destruir a sensação de fome e conseqüentemente o impulso e o desejo. “[...] os sonhos acordados provocados pela nossa vontade de mudança, as aspirações transformam-se em expectativas, sendo colocadas nas perspectivas das nossas possibilidades concretas” (BLOCH, 1970 apud FURTER, 1974, p. 85). Ora, é esta possibilidade de sonhar acordado que impulsiona os homens para o futuro e os leva a construir utopias.

Para Bloch, segundo Furter (1974), do mesmo modo que a esperança emerge no momento em que o homem toma consciência de que ele é um "ser de carências" e portanto inacabado, ele também não acredita que a fonte da utopia se encontra na consciência que o homem tem da sua perfeição, mas, ao contrário, do seu espanto diante da descoberta de sua imperfeição. Ora a consciência do seu "inacabamento" é o que impulsiona os homens para o futuro e a consciência das suas carências é o que os faz pensar em possibilidades para resolvê-las. Assim, são criadas as alternativas para a satisfação das muitas fomes que o homem tem, tais como: materiais, afetivas, sexuais e intelectuais. 
A utopia, para Bloch, segundo Furter, (1974) existe porque o homem se descobre imperfeito e quer ultrapassar este estado até atingir uma perfeição absoluta. Ao nos tornarmos conscientes das imperfeições do mundo, a utopia concreta aponta e chama a atenção para uma realidade transformável. Portanto a utopia pode induzir os homens a tudo, ela mobiliza os sujeitos a uma ação em favor de uma mudança. E, ainda segundo Bloch, é através da utopia concreta e da sua exigência de radicalidade que a esperança de virtude transforma-se em otimismo militante.

A reflexão sobre utopia impôs-se como uma necessidade de compreender a idéia de utopia presente nos ideais do Movimento dos Trabalhadores Sem Terra e no seu Projeto de Educação (MST, 1996). Como em Bloch e também para o MST, é o desejo de ir além que aumenta as dimensões humanas e amplia as possibilidades de ação.

\section{As ESCOLAS DO MST DA INTENÇÃO AO GESTO}

A educação pensada pelos Sem Terra visa ao mesmo tempo garantir o acesso de todas as crianças à escola, como também de uma escola transformada, com uma nova idéia de educação, em que ele não seja somente sinônimo de aula, de conteúdos e obediência, mas que seja um espaço que possa permitir aos educandos e educadores a não aceitação passiva do fatalismo da reprodução social.

Esta nova escola propugnada pelos Sem Terra, enquanto concepção, guarda uma estreita relação com o pensamento do italiano Antônio Gramsci e do brasileiro Paulo Freire, sobretudo no que se refere à escola formativa desinteressada e à pedagogia do oprimido.

Para Gramsci (1968), a escola formativa poderia proporcionar o acesso dos trabalhadores à cultura, devendo ser assegurada pelo Estado, quando este é ético e educador. Esta escola pensada por Gramsci, e igualmente pelo MST, deve possuir um caráter revolucionário, proporcionando aos trabalhadores e a seus filhos a superação da consciência ingênua e a construção de uma consciência crítica. Nessa perspectiva, tanto Gramsci como os sem-terra, ao refletirem sobre o caráter transformador da escola, abandonam a idéia dos reprodutivistas, de que a escola é somente espaço de reprodução e manutenção de uma ordem social que tende a ser excludente e dominadora. 
Um outro aspecto é o da idéia de libertação do sujeito, ou seja, da conquista da condição de cidadão, de sujeito da sua própria história - um novo homem uma nova mulher - que possa exercitar a condição de cidadão/ cidadã, de modo a potencializar sua capacidade de tomada de decisões. Almeja, portanto, uma escola que prepare os cidadãos, sujeitos sociais, capazes de conduzir à construção de um novo modelo de desenvolvimento para o campo e de uma nova sociedade.

Esse processo de libertação se instaura à medida, que se pensa uma escola diferente nos moldes tradicionais, garantindo uma autonomia que se configura em um "desde dentro", ou seja, a partir de dentro do assentamento, sem desprezar o "desde fora". As experiências de vida dos assentados traduzem elementos importantes para a prática educativa desse grupo, capazes de suscitar uma reflexão mais apurada rumo à construção coletiva do Projeto. São baseados na proposta de Freire de que a pedagogia do oprimido é construída a partir da realidade e da vida concreta dos sujeitos e que os temas geradores devem emergir da realidade ou das necessidades da comunidade, reconhecendo que esse grupo já possui um saber adquirido a partir da sua práxis.

A trajetória do setor de educação do MST é marcada pelos desdobramentos das necessidades que se foram impondo ao longo do tempo: das crianças ainda sem acesso à escolarização, das demandas por ensino fundamental, da qualificação técnica, em nível do ensino médio, para os jovens nas áreas de produção, administração e formação de professores para trabalharem com a população acampada, assentada; a educação infantil e a educação de jovens e adultos; e a implementação do curso superior em pedagogia para atender à crescente demanda de profissionalização dos jovens na área de educação.

Nessas múltiplas frentes de atuação, o MST vem elaborando princípios e orientações metodológicas que fundamentam o seu projeto pedagógico. Este projeto vem atender a uma demanda: a de sistematizar as experiências vividas no interior dos assentamentos e, a partir disso, consolidar um projeto mais elaborado de educação e de escola que faça valer os interesses dos assentados.

O MST, partindo desses princípios, reivindica do Estado que a escola pública dos assentamentos seja pensada e organizada para atender às necessidades do trabalhador rural. Enfim, a escola pensada pelos Sem Terra 
tem sido diferencialmente assumida pelas coordenações estaduais e regionais, procurando respeitar as diversidades locais.

Em Vitória da Conquista, o estudo demonstrou que as escolas, sob a coordenação do MST diferenciam-se das demais escolas do Município por vários motivos, a seguir apreciados.

Em primeiro lugar, o MST no Município tem estabelecido junto à Prefeitura canais de negociação, de modo a possibilitar a implementação do projeto na localidade, de forma que já se garantiu autonomia para coordenar as escolas em áreas de assentamentos; e indicar professores para serem contratados e fazer uma pré-seleção dos professores concursados que vão atuar em escolas de assentamentos. A seleção dos professores se dá com o intuito de garantir, pelo menos, um professor sensível à proposta de educação do Movimento.

Em segundo lugar, o Movimento tem buscado partir das práticas concretas da escolarização e das demandas da luta pela terra para formular seus conteúdos e metodologias de trabalho.

Em terceiro lugar, o MST tem conseguido garantir o acesso de todas as crianças às escolas, pelo menos nas séries iniciais do ensino fundamental, bem como, ampliar a concepção de leitura e escrita de modo que não se restrinja à decodificação das letras, mas valorizar a realidade do educando, dando-lhe vez e voz. Logrou, também, ocupar espaços na sociedade para o desenvolvimento de novos valores, estimulando práticas solidárias.

Em quarto, pode-se identificar a educação como fundamental na formação das crianças, dos jovens e adultos para se tornarem futuras lideranças do Movimento. As professoras relatam que, além de levarem em conta o conteúdo formal, também valorizam as questões históricas, políticas e ideológicas. Propõe-se uma educação que não se limite à transmissão de conhecimentos teóricos pré-estabelecidos, mas capacite a criança e o jovem para o trabalho agrário e para a concretização de suas expectativas de vida própria e do Movimento do qual fazem parte.

No entanto, o MST também ainda enfrenta desafios na construção de seu projeto de educação. A principal delas é a demora na transformação das rotinas das escolas e também a resistência dos professores e da comunidade na adoção de novidades ou de engajamentos em projetos vindos de fora do grupo. Isto gera uma defasagem entre a teorização da proposta educacional e a sua implementação nos assentamentos, uma vez 
que a prática escolar, segundo os princípios filosóficos e pedagógicos, não se tem realizado plenamente e por diversos motivos, listados como segue.

a) a permanência temporária dos professores nos assentamentos. Muitos professores, após serem formados pelo movimento, não retornam às suas bases, sendo aproveitados no trabalho de liderança; outros são desligados do movimento porque são transferidos por opção própria ou por ter vencido o período do contrato com a prefeitura. Foi observado que esta transitoriedade deve-se também ao fato de estes professores serem funcionários da Prefeitura e, em função disto, podem ausentar-se para a realização de cursos e reuniões na Secretaria de Educação do Município e residirem na cidade;

b) o conflito entre o projeto de educação do MST com o do Município. Ainda que os docentes atuem sob os princípios e coordenação do MST, eles estão, ao mesmo tempo, subordinados às normas da Secretaria Municipal, o que gera dificuldades para os professores, como a necessidade de adoção de procedimentos de avaliação adequados às normas da educação formal. Tal situação tem promovido um descompasso entre a reflexão sobre a educação e a implementação deste projeto;

c) a insuficiência de formação e qualificação de um quadro de professores, ainda, em sua maioria, formados na cidade para atuarem na cidade e não nas áreas rurais. A zona rural possui especificidades que demandam um profissional com formação específica, de forma a atender às condições e exigências dessas áreas;

d) a prioridade do MST à formação política e ideológica dos educandos, o que provoca, de certa forma, uma certa "limitação" dos indivíduos, prática esta contraditória com a própria utopia do projeto pedagógico do Movimento, que é o de educar para a libertação do homem, que este educando ou educanda possa ser capaz de possuir uma autonomia e fazer suas próprias escolhas e se tornarem "novos" homens e "novas" mulheres. 


\section{CONSIDERAÇÕES FINAIS}

Acreditando nas potencialidades dos assentados rurais ligados ao MST, colocam-se, aqui, os desafios que, por ora, devem despertar o desejo e estimular o grupo a continuar as suas lutas em busca da concretização da escola desejada.

1. Estabelecimento de escolas nos assentamentos com oferta do ensino fundamental completo e ensino médio, de forma que, os estudantes não precisem se deslocar do assentamento para a cidade para completarem seus estudos;

2. Formação e qualificação de um quadro de professores e gestores das próprias comunidades para implementar o projeto pedagógico pensado para os assentamentos, fazendo os necessários ajustes, de modo a se apropriar das exigências locais;

3. Estabelecimento de parcerias formalizadas ou não com outras organizações de agricultores, para ampliar a proposta de uma educação mais adequada não só para áreas de assentamentos, mas também para todo meio rural;

4. Formar parcerias com as Universidades locais a fim de ampliar o quadro de professores qualificados para trabalharem em comunidades rurais;

5. Prosseguir no esforço de transformar as escolas em espaços, onde a utopia permeie o seu cotidiano, alimentando a luta pela construção dessa nova sociedade.

Estes não são certamente desafios pequenos, no entanto são desafios que se fazem urgentes e requerem uma intensa mobilização para que ocorram as transformações necessárias.

\section{REFERÊNCIAS}

BLOCH, Ernest. The Spirit of Utopia. Stanford, California: Stanford University Press. 1970.

MOVIMENTO DOS TRABALHADORES SEM TERRA. Caderno de Educação: princípios da educação no MST. Porto Alegre, n. 8, 1996. 
DRUCK, Graça. Algumas considerações teóricas sobre o trabalho na sociedade capitalista. In: ESCOLA DE FORMAÇÃO SINDICAL DA CUT NO NORDESTE: DSS e Economia solidária. Recife: Bagaço, 2000. p. 11-23.

DRUCK, Graça. Globalização, reestruturação produtiva e movimento sindical. Cadernos CRH, Salvador, n. 24/25, p. 21-40, 1996.

FREIRE, Paulo. Pedagogia do oprimido. 25. ed. Rio de Janeiro: Paz e Terra, 1987.

FURTER, Pierre. A dialética da esperança. 6. ed. Rio de Janeiro: Paz e Terra, 1974.

GIDDENS, Anthony. As conseqüências da Modernidade. 6. ed. São Paulo: Unesp, 1991.

GOHN, Maria da Glória. Mídia, Terceiro setor e MST: impactos sobre o futuro das cidades e do campo. Petrópolis: Vozes, 2000.

GRAMSCI, Antônio. Concepção dialética da História. 4. ed. Tradução de Carlos Nelson Coutinho. Rio de Janeiro: Civilização Brasileira, 1981.

. Os intelectuais a organização da cultura. 3. ed. Tradução de Carlos Nelson Coutinho. Rio de Janeiro: Civilização Brasileira, 1968.

HOBSBAWN, Eric. Era dos extremos: o breve século XX - 1914-1991. São Paulo: Companhia das Letras, 1995.

LUDKE, Menga; ANDRÉ, Marli. Pesquisa em educação: abordagens qualitativas. São Paulo: E.P.U., 1986.

SCHERER-WARREN, Ilse. Redes de Movimentos Sociais. 2 ed. São Paulo: Loyola, 1996. 



\title{
Aspectos constitutivos para uma análise da escola inclusiva
}

Luciene Maria da Silva

\begin{abstract}
Mesmo sabendo que estamos ainda distante da universalização do ensino no Brasil ${ }^{1}$, é possível identificar a expansão do sistema educacional nas últimas décadas, fato que, certamente, tornou possível a inserção de um novo contingente de alunos na escola, forçando-nos ao reconhecimento da diversidade da sua composição, resultante das diferenças sociais, étnicas e culturais.
\end{abstract}

Essa crescente diversidade no âmbito da escola, resultado também da pressão social no sentido de mais oportunidades de escolarização para todos, vem se constituindo em objeto de investigação que dá centralidade às instituições escolares por se constituírem elas em espaço de possíveis práticas heterogêneas envolvendo sujeitos e identidades variadas. A escola pode ser considerada um espaço privilegiado para a observação de mudanças que vêm ocorrendo na sociedade. Busca-se saber sobre seus processos internos e quais são suas variáveis sem perder a perspectiva macro dos condicionantes sociais. As escolas são espaços onde os protagonistas expressam seus interesses e necessidades não apenas relacionados ao ensino e aprendizagem, pois que outras dimensões (políticas e subjetivas) também se manifestam. Pesquisadores com esse interesse têm utilizado diversos caminhos para coletar os dados sobre a organização da escola e sua estrutura

1 A esse respeito, Ferraro e Machado (2002, p. 238), em artigo que versa sobre a questão da universalização do acesso à escola no Brasil, concluem que a análise dos dados demográficos de 1980 a 1996 tornou evidente o avanço na incorporação da população em idade escolar nas redes de ensino, porém, "o não-acesso à escola, entendido como o conjunto da não freqüência" é ainda um problema a ser resolvido. 
social a partir de referenciais da sociologia com enfoque sobretudo nas relações entre a escola e a sociedade, vendo como os elementos culturais se apresentam, e também como são determinantes para a conformação das relações sociais.

É forçoso afirmar, que a instituição escolar vem sendo alvo de questionamentos importantes sobre seu papel na sociedade contemporânea. As críticas têm sido sobre o distanciamento da escola do "novo contexto" sócio-cultural, justificadas no fato de que os alunos precisam ter uma formação coerente com a sociedade para que assim possam atuar, parecendo sugerir que aqueles são exteriores a esta, como se a escola fosse uma cápsula formadora alheia às configurações sociais, porém com o poder de auscultálas, para assim formar indivíduos, também naturalizados, que posteriormente intervirão na sociedade. Entendemos que a escola é uma instituição da superestrutura da sociedade e, embora efetivamente reproduza de forma eficaz a ideologia dominante, tem um movimento mais lento de incorporação das mudanças que acontecem na base econômica. Por outro lado, esse aspecto determina uma especificidade para a escola, que passa a constituir-se num espaço menos vulnerável às pressões sociais, que poderia ser aproveitado exatamente para a crítica da sociedade.

Ademais, a questão de fundo que se coloca para a análise da educação escolar diz respeito ao fato de que, apesar da expansão do acesso à escola no Brasil nas duas últimas décadas, guardadas as devidas variações marcadas pelas desigualdades regionais, a permanência dos alunos, na escola, não se dá com o esperado tempo de permanência necessário à conclusão do ciclo básico. São variadas as formas de enfrentamento dessas questões: fala-se da necessidade de "reinventar" uma escola que favoreça os diversos espaços de produção do conhecimento e da informação; aposta-se na pluralidade de linguagens, no sentido de formar pessoas com capacidade reflexiva comprometida com um novo projeto de sociedade e humanidade; buscase denominações diversas para caracterizá-la, numa tentativa de mostrar seu novo desenho e assim, surgem as propostas de "escola da diferença", "escola cidadã", "escola plural” etc. Entretanto, se essa discussão se encontra num patamar fértil de análises, na prática escolar ela é ainda uma questão percebida de forma etnocêntrica e assimilacionista, porque os alunos identificados como "diferentes" são freqüentemente associados a comportamentos desviantes ou distantes das referências culturais 
consideradas relevantes. Isso evidencia que essas questões ultrapassam os limites dos processos educacionais, já que sua dimensão se estabelece para além do momento de instrução que se realiza no cotidiano da escola. $\mathrm{O}$ fato é que a visibilidade das diferenças tem provocado no ambiente da escola, atitudes de suspeitas e dúvidas, porque o contato e convívio com alunos diferentes perturbam e desordenam o já estabelecido.

Alunos que possuem atributos particulares por terem algum tipo de deficiência fazem parte desse universo e são classificados no âmbito da estrutura educacional como alunos vinculados à modalidade de atendimento educacional denominada Educação Especial. Esse campo consolidou-se a partir da forte influência da Psicologia e da Biologia com seus padrões de normalidade e classificações ajuizadas como adequadas e com o pressuposto de que indivíduos "especiais" podem ser educados por meio de procedimentos educacionais especiais, em escolas separadas do sistema regular de ensino.

Esse texto apresenta a proposta inclusivista, entendendo-a como uma abordagem crítica à educação especial, mas não só a ela, posto que pretende ser uma orientação que atenda às necessidades da diversidade dos alunos. Para isso iremos tecer breves considerações sobre os conceitos de inclusão e exclusão e posteriormente, analisar os fundamentos da Educação Inclusiva refletindo sobre aspectos relevantes para a sua realização.

\section{A Dialética EXCLUSÃo X INCLUSÃo}

A idéia de educação para todos os alunos no mesmo espaço escolar não é algo inédito atualmente, posto que é uma proposição antiga do movimento de integração. A diferença está em que a integração sempre enfatizou os limites do aluno para aprender, numa suposição de que a escola é boa para os alunos considerados normais, isentando-a de qualquer crítica sobre os seus resultados. O princípio de normalização ou a compreensão de que as pessoas com deficiência devem se aproximar ao máximo das experiências cotidianas tidas como normais, foi disseminado, no final da década de sessenta, sugerindo desde então o que posteriormente passou a ser entendido como integração, cuja abordagem na literatura pode referir-se a conceitos ou a sistemas organizacionais. 
As discussões sobre educação inclusiva no Brasil tomaram corpo na década de noventa do século XX, no rastro das discussões da Conferência Mundial sobre Educação para Todos realizada em Jontien/Tailândia, em 1990, por iniciativa da Organização das Nações Unidas para a Educação, Ciência e Cultura (UNESCO). No entanto, é o documento Declaração de Salamanca (UNESCO, 1996) resultado da histórica Conferência Mundial sobre Necessidades Educacionais Especiais: acesso e qualidade, evento que reuniu mais de trezentos representantes de 92 governos e 25 organizações internacionais na cidade de Salamanca (Espanha), em 1994, que marca as discussões sobre a temática (MENDES, 2002). Dois anos após sua realização foi sancionada no Brasil a Lei de Diretrizes e Bases da Educação Nacional $n^{\circ}$ 9.394/96, que possui um capítulo dedicado à Educação Especial e prevê em seu artigo 58, “o atendimento aos alunos com deficiência, preferencialmente na rede regular de ensino, em classes regulares, sendo oferecidos, quando necessários, serviços de apoio especializado para atender às peculiaridades do alunado". O atendimento em classes, escolas ou serviços especializados só deverá ser oferecido quando não for possível a integração destes alunos em classes regulares, devido às suas condições específicas.

Fatores variados contribuíram para a emergência e consolidação da discussão sobre inclusão: o movimento pelos direitos humanos, a desinstitucionalização das pessoas com deficiência, o surgimento de novos estudos e abordagens teóricas sobre a educação e aprendizagem, além dos encontros internacionais com foco na universalização do ensino, especialmente a Conferência Mundial de Educação para Todos em 1990 e a Conferência Mundial sobre Necessidades Educativas Especiais: acesso e qualidade, em 1994. É imprescindível entender a proposta inclusivista como um fenômeno histórico das sociedades contemporâneas, com seus condicionantes econômicos e políticos, no âmbito de reformas educacionais. A busca por inclusão de crianças e adolescentes com deficiência na escola não é um fato isolado dentro do sistema educacional brasileiro, pois sucede ao mesmo tempo diferentes tipos de demanda por inserção e permanência nessa instituição por parte de outras categorias de indivíduos para a realização da democratização da escola que ainda convive com elevadas taxas de evasão e repetência. O que se quer destacar é que a diretriz de inclusão escolar não emerge apenas dos anseios pela concretização dos 
direitos humanos, mas também das políticas globais, principalmente com o advento do neoliberalismo, orientadas pela lógica do capital que propugnam possibilitar "cidadania capaz de operar no mundo globalizado" (WARDE, 1998, p. 1).

Embora o movimento inclusivista na educação seja relacionado às pessoas com deficiência, o discurso veiculado pelas instituições internacionais e organismos governamentais, por meio de publicações e outros veículos de comunicação, é de que a inclusão deve ser pensada não apenas no sentido de expansão de oportunidades escolares, mas numa acepção alargada de sociedade inclusiva. $\mathrm{O}$ discurso sobre educação inclusiva incorpora alguns princípios para sua configuração como proposta pedagógica, cujo objetivo é incluir todos os alunos na rede regular de ensino, de modo a responder às suas necessidades.

O Brasil tem se comprometido oficialmente com o movimento inclusivista, não apenas por ser signatário de documentos internacionais mas, especialmente, por expor na legislação nacional diversas resoluções favoráveis a uma mudança de atitude para com as pessoas com deficiência, a exemplo da Lei Federal n ${ }^{\circ} 7.853$ e da Lei de Diretrizes e Bases da Educação Nacional (LDB) n ${ }^{\circ}$ 9.394/96. A partir da deliberação da LDB, o Ministério da Educação (MEC) passa a incorporar a temática da inclusão mais explicitamente em seus discursos, documentos e publicações - Revista Integração, Relatórios de Gestão, Série Atualidades Pedagógicas, - entre outros.

Sendo a inclusão a proposta considerada necessária e viável como mecanismo para garantir oportunidades para todos nos diversos setores da sociedade, a exclusão, como diagnóstico de uma realidade que se quer superar, tornou-se também um objeto de debates que está na pauta do discurso político e acadêmico, de cujas concepções são emanadas as políticas públicas. Muito se tem falado no Brasil sobre a exclusão social e econômica de grande parte de sua população, os considerados despossuídos e desapropriados de condições mínimas de sobrevivência, mas também dos segmentos de baixa renda da população que se encontram privados de bens materiais e simbólicos. Exclusão tornou-se um conceito que pode descrever os efeitos de uma insuficiente política social por parte do Estado ou ao recrudescimento do processo de desemprego gerado por uma nova configuração da sociedade capitalista. É um "termo denúncia”, bastante 
utilizado pela mídia para descrever qualquer tipo de carência identificada, levando à banalização do seu uso.

Além disso, o termo "exclusão" é, assim como o de identidade e diferença, algo escorregadio, que demanda desvelo para ser usado, posto que se transformou num "conceito abrigo" que serve para diversas categorias. Mesmo porque, os processos por que passam os diversos grupos marginalizados são extremamente diferenciados pelo contexto, pelas manifestações de repúdio por parte dos que excluem e mesmo pelo sentido do "ser excluído". Percebe-se que o termo "exclusão" busca correspondência com processos, indivíduos, categoria sociológica, justificativa para propostas e projetos sociais e econômicos, entre outros, tornando-se uma denominação para uma infinidade de situações.

A discussão sobre inclusão e exclusão torna-se simplista se não considera a sociedade na sua totalidade e, sobretudo, se não considera como se manifestam os fatos que evidenciam tais fenômenos. Se por um lado, a sociedade tem sido capaz de produzir inovações tecnológicas que se traduzem em bens materiais e culturais capazes de suprimir a pobreza e privação da população, por outro, não tem priorizado a distribuição eqüitativa desses bens, indicando, dessa forma, que o problema é menos de ordem econômica que social e político. Martins (2002) afirma que a categoria "exclusão" resulta de duas interpretações que não se conciliam, denominando-as de "orientação transformadora e orientação conservadora". A primeira, compreende o excluído como "vítima da exploração capitalista", projetando nele o agente histórico fundamental para ruptura do sistema excludente, posto que essa contradição leva a uma situação extrema que demanda solução: a transformação das relações sociais. No entanto, adverte o autor, essa possibilidade não é dada aos excluídos, mas aos incluídos na dinâmica do "processo de reprodução ampliada do capital", porque possuem canais de participação social, ainda que restritos.

Nesse sentido, essa categoria não tem correspondência com os que estão sendo chamados de excluídos - trabalhadores sem terra, sem teto, os que estão privados de escola ou de serviços, entre outros, e que, na verdade, experimentam situações transitórias e flutuantes que expressam uma inclusão precária. Daí deriva a sua constatação de que "exclusão" é uma categoria de "orientação conservadora", pois ao solicitar "inclusão" busca remediar necessidades no âmbito da mesma sociedade que denuncia. 
A fragilidade da categoria, exclusão educacional, é marcada pela perda da perspectiva de relação e movimento, na medida em que torna os sujeitos "excluídos" uma espécie de seres amorfos, que estando do lado de fora acatam a inexorabilidade de sua exclusão, tornando invisível a sua atuação como sujeitos que podem, pressionam e reivindicam, mesmo sabendo que esse indicativos de resistência estão cada vez mais escassos. Nesse sentido, excluídos seriam os que estão de fora, no limbo, demandando por meio de um sentimento de compaixão ou de justiça que outros agentes externos se mobilizem em sua causa. Essa relação, por certo, inviabiliza o que ainda pode restar de resistência. Embora saibamos que a fragmentação da sociedade contemporânea não pode ser atribuída apenas à divisão de classes sociais, posto que outros indicadores além do econômico se interpõem para a configuração de tal fracionamento, consideramos que é ainda a luta de classes, com suas contemporâneas expressões, que realça o movimento de enfrentamento e de correlação de forças que possibilita o acesso aos bens produzidos pela sociedade ou o contrário.

A exclusão de diversos segmentos sociais na sociedade capitalista é um fenômeno previsível, visto que são incorporados visando a manutenção do próprio sistema, sendo, portanto, necessário que eles sejam incluídos, absorvidos e adaptados. Para isso a educação é de fundamental importância como diretriz de desenvolvimento necessária à reprodução do capital entrando fortemente na agenda política dos países, com o objetivo tácito de desenvolver as habilidades necessárias para "operar no mundo globalizado" (WARDE, 1998, p. 1). As diretrizes das reformas dos anos 1990 são resultado das formulações das agências internacionais que têm como propósito maior o reparo das finanças públicas com a devida racionalização de mercado. E a inclusão dos segmentos vitimados por processos de segregação, principalmente os que intensificam a pobreza, pode ser entendido como um mecanismo de integração viável nessa mesma sociedade que produz a denominada exclusão, decorrente dela própria.

A inclusão está hoje nos discursos dominantes no campo da política, dos programas dos partidos políticos e instituições conservadoras, numa clara apropriação das elaborações teóricas progressistas que há muito fazem parte das falas dos que lutam pela igualdade e dos que se consideram excluídos. Porém, o que vem sendo denominado por diferenças em muitos discursos em defesa da inclusão confunde-se com desigualdade, que são 
diferenças socialmente produzidas no âmbito de determinadas relações sociais, que confere privilégios e direitos distintos para um segmento da população.

\section{O ACOLHIMENTO DA DIVERSIDADE NA ESCOLA}

No debate entre os educadores, a discussão sobre educação inclusiva tem gerado polêmicas. Alguns entendem que é o princípio da inclusão social que deve ser defendido, na medida em que reforça um outro princípio semelhante que é o de educação para todos. Para esses, a viabilização e incorporação das mudanças demandam condições materiais de aparelhamento das escolas e capacitação dos professores, sob pena de a proposta constituir-se em uma nova exclusão. Outros se posicionam de forma mais radical em favor da inclusão, tendo como idéia central que o convívio com a diversidade das condições humanas é necessário e benéfico à formação de todas as crianças, especiais ou não. Defendem a desinstitucionalização de todas as crianças e têm como meta primordial não deixar ninguém fora do ensino regular.

Muito se discutiu a respeito da diferenciação terminológica entre integração e inclusão. Embora ao termo integração possamos atribuir significados variados relacionados aos diferentes ramos do conhecimento (sociologia, psicologia, antropologia), a compreensão que o diferencia de inclusão educacional diz respeito à ênfase que é dada para o aluno adaptarse à escola sem que seja considerado a necessidade de mudanças, posto que o ensino tem uma abordagem unidimensional e generalizante. É o aluno quem deve preparar-se previamente para as adversidades sociais na forma de discriminação, impedimentos ao trabalho, inacessibilidade etc. São os movimentos civis que mais insistem nessa precisão: integração seria um caminho de mão única em que apenas a pessoa com deficiência modificarse-ia para responder às solicitações sociais referentes à educação (escolarização), saúde (reabilitação), entre outros.

A inclusão é colocada numa perspectiva contrária à da integração: a atenção é deslocada do aluno com deficiência para o conjunto de recursos que lhes são necessários em determinado momento da sua trajetória escolar e o que é considerado déficit do indivíduo passa a ser responsabilidade, também, da interação entre ele e o meio em que vive. A própria Educação 
Especial passa a ser questionada nos seus objetivos e, principalmente, no que toca à sua forma de organização escolar, que busca tornar os alunos "especiais" seres adaptados e considerados de forma fragmentada a partir do que percebem como função prejudicada.

Bueno (2004) faz uma reflexão que coloca essas concepções de educação - integração e inclusão - como resultado da caracterização que se faz da escola, principalmente em referência aos seus resultados. Afirma que, se considerarmos, por uma visão acrítica da escola, que o problema está no aluno com deficiência, estaremos assumindo que a escola vem desempenhando bem seu papel. E, se considerarmos que existem alunos diferentes, e que, portanto, a escola deve mudar para incorporá-los, é porque sabemos que mantendo a escola como é, atualmente, não haverá educação com qualidade. É importante situar o problema do fracasso escolar, na inadequação da estrutura da escola, que é proveniente das diretrizes educacionais, e não do indivíduo, contemplando, assim, uma dimensão mais ampla que abrange as determinações políticas e econômicas e desmistifica a concepção de desvio ou déficit que põe a criança, que tem necessidades educacionais especiais, como anormal. Ou seja, a preocupação com a formação dos professores como uma condição necessária e fundamental não é suficiente para a melhoria da qualidade de qualquer que seja a modalidade de ensino, posto que a questão de fundo está na manutenção de um sistema de ensino que, ao longo da história, tem reproduzido de forma persistente processos de marginalização de parcela considerável da população escolar.

A reflexão sobre o perfil do professor que irá aprimorar a educação escolar num sentido inclusivista tem suscitado discussões sobre o tipo de formação que responda aos objetivos propugnados. Para assegurar a aprendizagem de todos os alunos parece claro que o planejamento escolar deverá considerar reflexões teórico-práticas consistentes que abranjam situações diversas e que demandam procedimentos pedagógicos, por vezes específicos, coerentes com as necessidades identificadas na classe.

Entre os professores, vigora um mito de que o aluno com deficiência demanda uma série de técnicas e métodos para aprender, devendo haver um currículo especial ou um artefato técnico específico sugerindo todo tipo de adaptações. Essas preocupações dos professores são procedentes, mas não tão impossíveis de serem encaminhadas como eles parecem atribuir. 
Os professores precisam ser incentivados a elaborar respostas teóricopráticas para o seu trabalho cotidiano. Na verdade, estas constatações não buscam supervalorizar as relações professor aluno, posto que estas não têm que ser harmoniosas ou sem tensões, considerando o conteúdo próprio de cada um desses sujeitos, porém é inegável que na maioria das vezes as interações, na escola, são saturadas de elementos dissonantes que resultam no desinteresse dos alunos. Ainda precisamos contar com o professor especialista para apoiar o professor das classes regulares nas atividades que exigem conhecimentos pedagógicos específicos sobre as deficiências, tornando falsa a dicotomia professor especialista $\mathrm{X}$ generalista, que culpabiliza o primeiro pela segregação dos alunos em contraposição à competência do segundo para promover o ensino inclusivo.

Mas, o conhecimento especializado, sem a devida vinculação com os fatores sócio-culturais, descontextualiza a prática pedagógica. $\mathrm{O}$ especial quase sempre é discutido dentro do próprio contexto, buscando soluções viabilizáveis dentro dos procedimentos das técnicas e metodologias. A área de Educação Especial não pode estar restrita nas suas análises apenas ao âmbito educacional, pois ela não evidencia as variadas perspectivas de análise, uma vez que a impossibilidade de os alunos com deficiência ingressarem na escola não se limita às práticas pedagógicas, embora nelas encontre terreno favorável para produção e reprodução da condição de marginalizados.

É importante salientar também que as desvantagens e limitações das pessoas com deficiência para suas atividades cotidianas dizem respeito à ausência de acessibilidade, e, principalmente, à sua condição ou posição que ocupa na sociedade. As relações humanas se constituem pelas reações de trocas subjetivas suscitadas no encontro com o outro, sendo observável nuanças de aproximação ou distanciamento, tais como desconhecimento ou negação do outro, indiferença, intolerância, receptividade, aceitação, simpatia, entre outros. Porém, o critério que vai efetivamente compor as relações sociais é o contexto, que se define no tempo/espaço histórico com características determinadas, sendo que a humanidade ainda não experimentou uma situação favorável ao acolhimento da diferença. É na coletividade que as normas são produzidas, atribuindo valores a partir das necessidades de ordem moral ou econômica. O desejável para qualquer sociedade é a cumplicidade em torno das expectativas valorativas que se fizeram normas, na medida em que foram incorporadas na vida social. 
A rejeição da deficiência como preconceito diz mais da condição de menoridade que ainda estão submetidos os seres humanos nas relações sociais, daí decorrendo os processos de segregação ou de integração, do que da condição de limitação resultante de uma determinada patologia. $\mathrm{O}$ olhar para uma análise crítica sobre a discriminação acerca da deficiência deve estar detido para o contexto que a identifica como um desvio que é particular assim como o é para outras situações de segregação que permeiam a vida coletiva. E mesmo no âmbito das deficiências, é razoável considerar as condições das pessoas que são discriminadas, posto que para algumas, oportunidades são dadas em função da sua posição e participação na teia das relações sociais concretas. Goffman (1998, p. 138) é contundente quando afirma: "Está, então, implícito, que não é para o deficiente que se deve olhar em busca da compreensão da diferença, mas para o comum".

O desvio que se estabelece nas relações sociais é manipulado no sentido de tornar viável a realização de um projeto de sociedade que, para funcionar com equilíbrio, deve dirimir as situações de tensão e conflito, num movimento de reforço e atualização dos limites do que é normal e das “expectativas normativas" do corpo social (OMOTE, 1995, p. 59). Dessa forma, a perspectiva de sociedade inclusiva se reporta a uma quase abstração ao não considerar os condicionantes histórico-culturais, explicitando seu caráter idealista, posto que admite que, pela expansão da educação inclusivista, as relações sociais se transformarão rumo a uma outra sociedade que admita as diferenças. Parece ser novamente a concepção da educação como redentora da sociedade desajustada, em que sua posição é deslocada de determinada para determinante. Ou uma proposição recortada da história, pois mesmo havendo uma legislação favorável não existe um acolhimento por parte da sociedade, que mantém uma estrutura pautada em relações desiguais e discriminadoras, dificultando uma orientação institucional voltada para a adaptação da escola às necessidades dos alunos. Tal argumentação sugere que a segregação pode recrudescer ainda mais, porque a (pseudo) inclusão, estando direcionada para o aluno, irá responsabilizá-lo nos casos de sucesso ou fracasso escolar. O que se põe em questão é a possibilidade de, mediante programas e propostas educacionais, tornar a escola um espaço propício para resolução de conflitos e contradições que se encontram no âmbito das relações sociais. 
As considerações críticas direcionadas à educação inclusiva intentam explicar a contraditoriedade dos pressupostos que lhe são imputados desde sua origem pelos organismos internacionais. De fato, pouco tem sido realizado no que diz respeito às suas diretrizes práticas, quais sejam, tornar realidade a escolarização de alunos com necessidades educacionais especiais nas escolas regulares, garantindo uma educação com qualidade para todos. Isso demanda a superação de mecanismos impeditivos para o acesso e permanência desses alunos, formação adequada para os professores e melhoria das condições materiais e físicas das escolas.

A demanda da escola inclusiva se insere na dinâmica da sociedade atual, no sentido de afirmação dos direitos sociais proclamados pela democracia formal, entendendo que pessoas com deficiência são sujeitos inteiros, independentemente de seus atributos. Consideramos, todavia, que essas são questões fundamentais para a educação de todos os alunos, posto que são diferentes, não cabendo formulações e políticas educacionais diferenciadas, no que se refere às condições para sua implementação. A preocupação evidente da educação inclusivista com os alunos que têm deficiência não é por outro motivo que o fato de que são esses os que estão mais culturalmente marginalizados e sob o risco de segregação por meio dos mecanismos mais irracionais que a sociedade cria. Busca-se uma educação que leve todos os alunos a aprender na escola com professores que possam organizar ambientes de aprendizagem para todos os alunos.

De fato, as diferenças humanas não têm sido reforçadas pela sociedade e a escola pouco tem feito para mudar essa prática, visível pelas políticas educacionais no que se refere à formação dos professores, orientação curricular, organização e gestão da escola. A escola segue cumprindo suas funções imediatas e, ao mesmo tempo, respondendo às necessidades atuais das políticas educacionais tensionadas pelas diversas práticas pedagógicas e supostas inovações teórico-metodológicas que incorporam cada vez mais os meios de comunicação de massa e as novas tecnologias. E a pseudoformação é determinante para a legitimação de tal (de)formação, pois, embora ultrapasse os muros da escola, é nela que encontra espaço favorável para atuar, devido às suas funções e a sua condição atual precária. Nesse processo, a ideologia tem papel fundamental para a integração social. Sua função é a de ocultar as contradições, legitimando a realidade existente e, assim, perpetuando-a, ao tempo em que impede a reelaboração e 
impossibilita experiências formadoras. O desencantamento do mundo tornou-se um paradoxo, pois, abstraiu das experiências a aproximação com as imagens e formas, substituídas pelo discurso elaborado em que o conteúdo é representado a partir de recursos tecnológicos, o que favorece um outro tipo de encantamento que nada tem de racional.

A formação deveria tornar possível a autonomia dos indivíduos, para que possam se apropriar de forma espontânea e livre do que a cultura pode oferecer-lhes. Afinal, na atualidade, as seleções ou opções dos indivíduos dizem menos do que eles realmente necessitam e mais em função de pseudo-necessidades, forjadas para cumprimento de compromissos. A indústria cultural oferece satisfações que reforçam ainda mais a adesão a uma forma de viver que contraria os próprios interesses. É o sentimento de impotência que leva os indivíduos a desistir de seus ideais, por perceberem a realidade como algo imutável.

Propostas de inclusão justificadas pela idéia de harmonia da diversidade necessária ao bom funcionamento da sociedade, sem considerar a essência das individualidades e vendo a escola como se fosse uma unidade de transformação social, é uma forma de adaptação que não proporciona formação porque, de fato, não são superadas as representações da deficiência como inferioridade e incapacidade nem esclarecidas suas determinações constituídas na teia das relações sociais.

A inclusão é uma proposta que pode ser caracterizada como uma proposta liberal para a educação, como o são as demais políticas compensatórias. Os princípios universais formulados pelo liberalismo põem ênfase nos direitos do homem e tem a educação como um meio para o indivíduo fazer-se indivíduo social. Essa orientação ainda está para ser cumprida, mesmo que a sociedade já tenha conseguido avançar em outros aspectos. A proposta de colocar todos os alunos na escola regular pode favorecer a identificação, base para uma educação mais humana que admita a aproximação com o outro.

É no âmbito das relações sociais que a atividade humana se configura pela apreensão do imediato e a compreensão posterior do real pelo conhecimento; é aí que está a possibilidade de desenvolvimento dos homens e da sua individualidade considerando as particularidades e um projeto de sociedade que as incorpore. Nesse sentido, a convivência com a diferença é um aspecto constitutivo para tal aspiração, na medida em que a reconhece 
como "essência da humanidade e não como exceção da regra" (CROCHIK, 1997, p. 13). Assim entendida, como o que nos faz singular, busca a aproximação do outro na busca por identificação possibilitando o reconhecimento da diversidade. Esse processo de diferenciação e identificação só é possível com a interação e o contato para a realização dos vínculos, das trocas afetivas e cognitivas que enriquecem as relações sociais e favorecem a individuação. Com efeito, a diversidade compõe-se de singularidades e diferenças e estas não deveriam se constituir numa oposição binária.

Mesmo considerando que a adaptação é necessária tendo em vista uma orientação da atividade humana na sua relação com o meio social, ela não pode anular a possibilidade da escola resistir à tendência de uniformização e negação da individualidade, o que induziria a sua caracterização como uma instituição burocrática que visa meramente cumprir funções de distribuição, seleção social e transmissão de conteúdos culturais e científicos.

A escola tem incorporado o discurso da diferença, mas não sabe ainda o que fazer com ela, limitando-se a nomeá-la e classificá-la. Dessa forma, a heterogeneidade é diluída, reduzindo mesmo a perplexidade inicial do contato: educa-se para a diferença na indiferença. Isso é o resultado de um processo determinado objetivamente, cujos mecanismos de concretização não se reduzem aos utilizados pela educação escolar.

Grande parte da população, entretanto, está à margem dessa discussão. Nos circuitos mais próximos - Faculdades de Educação, Secretarias de Educação e Instituições Especializadas -, a discussão sobre o que significa inclusão ainda é muito precária e confusa. Mesmo no âmbito da academia, muitos se mostram indiferentes à questão, levando-os, quando informados, a questionar sobre a viabilidade da proposta, a adaptação das crianças, a carência de recursos materiais, entre outros, sem mostrar, porém, um compromisso maior, como se fosse uma necessidade distante. Muitos professores têm se comportado de forma semelhante à indústria cultural, ao transmitir bens culturais fossilizados ou tentando adaptá-los ao máximo ao gosto dos alunos. Com essa incumbência, os professores, que já têm a marca da deformação na sua própria formação, seguem veiculando um conhecimento que se presta mais à domesticação. A maioria dos cursos de formação de professores continua ignorando o fato de que seus egressos irão encontrar alunos com deficiência nas classes, pois na sua estrutura 
curricular, essa temática é apenas sugerida nas ementas das disciplinas da área de Psicologia.

Concluir que a escola é irrecuperável é contraditoriamente admitir a concepção fatalista de que nada escapa do controle absoluto da pseudoformação, cedendo a uma leitura indefectível da reprodução do sistema social por meio da educação escolar. A perspectiva já anunciada no âmbito da Teoria Crítica está na reflexão sobre a formação e seus condicionantes. Cabe enfatizar e defender a emancipação, a autonomia e a diferenciação como possíveis aos seres humanos; entendê-los como indivíduos capazes de dar sentido, pela reflexão elaborada, às situações e interações no mundo em que vivem.

Dessa forma, a defesa da escola inclusiva não pode estar restrita apenas à expansão de oferta de vagas, pois isso diz respeito a uma exigência imediata da sociedade como um preceito pretensamente racional e pragmático de utilidade e eficiência. A falência do sistema educacional não se reverte com reformas, se limitadas a ações no âmbito pedagógicoescolar, numa tentativa de harmonização de instâncias contraditórias.

A proposta de inclusão no contexto da democracia formal traz acoplada a idéia liberal de expansão do ensino sem rever os princípios que lhes são adjacentes, no que diz respeito aos conteúdos e currículo, formação de professores, infra-estrutura da escola e relações sociais. Na verdade, prioriza o discurso de aceitação das diferenças secundarizando o necessário esclarecimento sobre a condição para que haja uma efetiva melhoria de qualidade do ensino. Porém, defendê-la é tornar possível o avanço das reflexões sobre a formação que admita a diferenciação. Pode ser um instrumento questionador dos preconceitos que, por dificultar o contato com pessoas diferentes, não possibilita a experiência. E o pensamento que prescinde dela é puramente formal. É ela que permite a identificação com o outro a partir da idéia de ser igual na diferença.

A educação inclusiva, de certa forma, vem proporcionando a discussão entre os educadores com uma abordagem ampla, saindo do puro aspecto da deficiência como anormalidade que necessita de intervenção e que privilegia o enfoque das áreas de instrumentalização de propostas metodológicas, para uma discussão sobre o que acontece no âmbito das instituições especiais, nas relações que se dão no interior das escolas e classes especiais, nas (im)possibilidades de trabalho e nas experiências de integração. 
Estamos numa fase em que o discurso da inclusão já foi sistematizado e parece ter sido assimilado pelos sistemas de ensino, e, até ONGs que preservavam o sistema segregado e mesmo resistiram à proposta, estão atualmente pregando a escola inclusiva. Parece claro que esse movimento pode ser uma perspectiva de melhoria do atendimento educacional para todos os alunos e, dessa forma, constituir-se numa reforma, cujo objetivo é proporcionar a escolarização das pessoas com deficiência, o que nada tem de revolucionário. É necessário assumirmos o risco de negar a política inclusivista sem recusar o que ela tem de progressivo para a atual sociedade. E, nesse sentido, diferenciar a crítica identificando os aspectos de resistência dos que se opõem à afirmação da diferença, pois no fundo, esta é uma ameaça para a tirania de uma minoria que se fortalece pela desigualdade institucionalizada, que produz e reproduz insistentemente as anormalidades.

As dificuldades práticas que se tem posto para dar acesso aos alunos com deficiência à escola regular, mesmo com orientações tão precisas como as que estão propostas pelos documentos analisados, está na direta proporção da relutância em revogar as distinções entre normal e anormal, tão intensamente consolidadas. Parece que se nega a diferença para que o atributo considerado estranho passe a pertencer absolutamente àquele que causa estranheza. Ou seja, circunscreve-se determinadas anormalidades nos limites do indivíduo, subtraindo tudo que na verdade pertence às determinações da sociedade. A urgência pela inclusão e as críticas que vêm sendo elaboradas à Educação Especial não podem ocultar o fato de que a formação danificada já se encontra prefigurada nas práticas educativas, seja ela para alunos com deficiência ou não.

\section{REFERÊNCIAS}

ADORNO, T. W. Teoria da semicultura. Educação e Sociedade, Campinas: n. 56, p. 389- 411, 1996.

BRASIL. Lei de Diretrizes e Bases da Educação Nacional, no 9394/96. Disponível em: <www.educação.gov.br/seesp/pdf/lei_9394_ldbn1.pdf>. Acesso em: 17 mar. 2002.

BUENO, José G. Silveira. Educação Especial: integração/segregação do aluno diferente. São Paulo: EDUC/PUCSP, 2004. 
CROCHIK, J. Leon. Preconceito. Indivíduo e Cultura. São Paulo: Robe, 1997.

FERRARO, Alceu Ravanello; MACHADO, Nádie C. Ferreira. Da universalização do acesso à escola no Brasil. Revista Educação e Sociedade. Campinas, n. 79, 2002.

GOFFMAN, Erving. Estigma. Notas sobre a manipulação da identidade deteriorada. Rio de Janeiro: Zahar Ed., 1998.

MARTINS, José de Souza. A sociedade vista do abismo: novos estudos sobre exclusão, pobreza e classes sociais. Petrópolis: Vozes, 2002.

MENDES, Eniceia. Perspectivas para a construção da escola inclusiva no Brasil. In: PALHARES, Marina Silveira; MARINS, Simone Cristina. Escola inclusiva. São Carlos: Edufscar, 2002.

OMOTE, Sadao. A integração do deficiente: um pseudo-problema científico. Temas em Psicologia. São Paulo, n. 2, p. 55-62, 1995.

UNESCO. Declaração de Salamanca. Disponível em: <www.educação. gov.br/seesp/pdf/salamanca.pdf>. Acesso em: 29 out. 2001.

. Declaração Mundial sobre Educação para Todos. Disponível em: <www.intelegis.gov.br>. Acesso em: 29 out. 2001.

WARDE, Mirian Jorge. A educação escolar no marco das novas políticas educacionais. In: WARDE, Mirian Jorge (Org.). Novas politicas educacionais: críticas e perspectivas. São Paulo: Programa de Estudos PósGraduados em Educação: História e Filosofia da Educação da Pontifícia Universidade Católica de São Paulo, 1998. 



\title{
A representação social da transferência do professor e do aluno na sala de aula
}

\author{
Maria de Lourdes S. Ornellas
}

Vamos bordando a nossa vida, sem conhecer por inteiro o risco; representamos o nosso papel, sem conhecer por inteiro a peça. De vez em quando voltamos a olhar o bordado já feito e sob ele desvendamos o risco desconhecido (SOARES, 1990, p. 25).

Representação social é uma representação de palavra que faz laço com a educação e a afetividade, e é por essa via de enlace que esse escrito está sendo bordado, quando no início das minhas pesquisas sobre a temática os primeiros riscos, pontos e alinhavos esboçavam no bastidor algumas formas e texturas em que minha escuta do avesso se confundia com o direito.

Introduzir este texto com uma epígrafe que fala de risco e bordado tem uma intenção: revelar que a teoria das representações sociais ao mesmo tempo em que vai além das bordas, traz a linha e a agulha e no encontro com o tecimento se aproxima da cor, do desenho e do risco para se chegar ao afeto e à educação. É possível dizer também que esta temática revele a urdidura em que a teoria das representações sociais, a educação e a afetividade podem enlaçar o cotidiano escolar. Vale ressaltar que nesse estudo o conceito de representação social se assenta em Moscovici e Jodelet; a educação se referencia no recorte da relação professor/aluno e a afetividade é colocada tomando como referências Freud e Lacan. 
A representação social é um conhecimento do senso comum e é formada em razão do cotidiano do sujeito. É uma abordagem que se encontra hoje no centro de um debate interdisciplinar, na medida em que se tenta nomear, fazer relações entre as construções simbólicas com a realidade social e dirige seu olhar epistêmico para entender como esta realidade constrói a leitura dos símbolos presentes no nosso cotidiano. Neste entendimento, a fala de Moscovici (1978, p. 181) nos convida a refletir sobre conceito:

Por representações sociais, entendemos um conjunto de conceitos, proposições e explicações na vida cotidiana no curso de comunicação interpessoal. Elas são o equivalente, em nossa sociedade, aos mitos e sistemas de crenças das sociedades tradicionais; podem também ser vistas como a versão contemporânea do senso comum.

Os estudos desenvolvidos no campo das representações sociais, nos últimos 30 anos, consensualmente reportam-se ao conceito trabalhado por Moscovici (1978) e tomam como referência o seu estudo publicado em La psychanalyse, son image et son public. A obra aponta para a dificuldade de conceituar as representações sociais, admitindo que se, por um lado, o fenômeno é passível de observação e de identificação, por outro, o conceito, por sua complexidade, requer um tempo de maturação para que a definição seja construída de modo consistente.

Allport usa uma metáfora para historiar a origem da representação social e sugere uma unidade orgânica entre a flor e a raiz:

Tanto a flor como suas raízes são européias, e existe uma similaridade na forma entre a flor (uma forma sociológica de psicologia social) e a semente da qual ela nasceu (isto é, a sociologia). No caso da psicologia social, a semente e o solo em que germinou provieram de continentes diferentes (Europa e América do Norte) e de diferentes disciplinas acadêmicas (sociologia e psicologia) (FARR, 1998, p. 31-32).

Essa história, além de sinalizar a origem, pontua os terrenos demarcados pela representação social. Trata-se de um conceito germinado nesta complexidade, no entanto, não é apenas a soma das contribuições advindas dos estudiosos, é a construção de algo de novo, pretendendo observar um fenômeno básico da realidade cotidiana.

As obras de Moscovici (1978) e Ibañez (1988) sinalizam duas justificativas para essa complexibilidade conceptual: a primeira refere-se 
ao fato de que a representação social é um conceito híbrido, não pertencendo a uma única área do conhecimento, visto que sua origem vincula-se tanto à Sociologia quanto à Psicologia - o que leva a pensar que a representação social é um conceito psicossocial. A outra justificativa deriva da primeira, pois como os conceitos aglutinados de outras áreas são mais restritos, uma vez que tratam basicamente de objetos e não de fenômenos, constituem, em relação ao próprio conceito de representação social, os mais operativos.

Pode-se dizer que a representação social, ao estudar o sujeito em processo de interação com outros sujeitos, expressa uma espécie de saber prático de como os sujeitos sentem, assimilam, aprendem e interpretam o mundo, inseridos no seu cotidiano, sendo, portanto, produzidos coletivamente na prática da sociedade e no decorrer da comunicação entre os sujeitos. Nesta lógica, Jodelet (2001, p. 41) aprofunda o construto:

As representações sociais devem ser estudadas articulando elementos afetivos, mentais e sociais e integrando, ao lado da cognição da linguagem e da comunicação, as relações sociais que afetam as representações e a realidade material, social e ideal sobre as quais elas intervirão.

É possível pontuar que esse conhecimento tem uma base cognitiva e afetiva e que não constitui uma categoria bipolar, podendo-se, desse modo, ser afirmado que as representações sociais não são saberes articulados apenas ao cognitivo, mas que se tecem, de forma dinâmica, em um processo histórico, que envolve tanto a racionalidade quanto a afetividade.

Pesquisadores da área de Educação e também fora dela mostram-se preocupados em integrar aspectos afetivos e simbólicos na elucidação e análise das representações sociais, concebendo que na atividade representativa o objeto deixa de existir como tal, para se converter num equivalente dos objetos aos quais foi vinculado como uma contingência psicossocial. Moscovici (1970) pensa a representação associada às experiências subjetivas do sujeito, expressas na comunicação social, simultaneamente como um produto e um processo: “a atividade representativa constitui, portanto, um processo psíquico que permite tornar familiar e presente em nosso universo interior; um objeto que está distante e, de certo modo, ausente" (MOSCOVICI, 1978, p. 28). 
No papel de sujeitos cognitivos, afetivos e sociais, os indivíduos produzem e comunicam aos seus pares, incessantemente, suas próprias representações, designadas tanto por conteúdos conscientes como por processos inconscientes. A fala a seguir explicita o processo:

Identificar a natureza complexa das representações sociais implica, inevitavelmente, estabelecer um intercâmbio entre intersubjetividades e o coletivo, na combinação de um saber que não se dá apenas por processos cognitivos, mas que contém aspectos inconscientes, emocionais, afetivos, tanto na produção como na reprodução das representações sociais (LANE, 1993, p. 61).

$\mathrm{Na}$ última década, o estudo das representações sociais tem espaço garantido na educação e de modo específico na Psicologia da Educação. Observa-se hoje um número cada vez maior de pesquisas nessa área, o que pode contribuir para a construção de um novo olhar no que se refere aos processos educativos e subjetivos que interagem na sala de aula. Nesse sentido, Souza (2002, p. 286) nos diz:

No final da década de 1980 e início dos anos 90, as investigações nas áreas de educação passaram a exigir construções teóricas que conciliassem pontos de vista do autor individual e do autor social e de perspectiva micro e macro. É nesse contexto que a "descoberta" da teoria das representações sociais, pelos educadores, surge como uma das possibilidades teóricas relevantes da área da Psicologia, possibilitando a compreensão de um sujeito sócio-historicamente situado e, ao mesmo tempo, formando condições para a análise de dinâmicas subjetivas.

Aspectos afetivos constituem-se de processos subjetivos que emergem no interior da sala de aula, e é possível que a psicanálise possa contribuir com esse debate na sala de aula e que as representações sociais de professores e alunos apontem para a escola que queremos construir.

Freud (1905) acalentava um sonho de que a psicanálise pudesse um dia vir a contribuir com a sociedade como um todo e, especialmente, com a educação; acompanhava os movimentos sociais e desejava que a psicanálise pudesse estender-se a outras áreas do conhecimento. A partir daí a psicanálise, ainda que sutilmente, ousou adentrar os muros da escola.

A psicanálise não tem receitas sobre o que deve ser feito na escola, mas reflete sobre o que tem sido feito, uma vez que pode contribuir na escuta do discurso do professor e do aluno. Articular psicanálise e educação é um grande 
desafio, e o fato de a psicanálise se oferecer como um importante fundante do instrumento da escuta é o que nos permite muitas vezes contribuir para a leitura do mal-estar vivido pelo professor no contexto educativo.

O mal-estar na escola tem diversas faces para serem olhadas e pensadas: é como se olhássemos um cubo, que tem seis faces, como sabemos, mas só podemos, de um determinado lugar, ver três faces, é necessário que nos desloquemos para que vejamos todas as faces (OUTEIRAL; CEREZER, 1994, p. 1).

Pela escuta cuidadosa dos sintomas presentes no mal-estar na sala de aula, por parte do professor, é que penso que algumas fronteiras são possíveis entre psicanálise e educação. É preciso, pois, escutar o ambiente transferencial de sala de aula, lugar no qual acontece o ato educativo. É nesse ambiente que ocorre a escuta da relação professor/aluno, visto como um campo de mediação entre os sujeitos que, no espaço escolar, se configura sob a nomeação de disciplina ou (in)disciplina escolar, constituindo, na atualidade, uma das preocupações mais emergentes do professor.

$\mathrm{Na}$ contemporaneidade, quando se dirige para a sala de aula, o professor se questiona acerca de como administrar a dispersão, a falta de atenção e de interesse pelas atividades desenvolvidas em classe. Diante desse malestar no ambiente escolar, a escuta pedagógica pode abrir um canal de comunicação, porque o instrumento da escuta pedagógica envolve não só o sentido do ouvir, mas o de fazer uma leitura subjetiva do discurso, apresentado pelo sujeito escutante.

Por este caminho, em que a escuta é vista essencialmente como instrumento de trabalho do professor, Kupfer (2000, p. 34) diz:

Uma leitura que inclua o discurso social que circula em torno do educativo e do escolar [...] estará produzindo uma inflexão na ação do psicanalista e o levará a uma prática que não coincida mais com a clínica psicanalista 'ortodoxa', pois ele terá de se movimentar o suficiente para ouvir pais e escola. Isso amplia o campo de ação do psicanalista, que passa a incluir a instituição escola como lugar de escuta.

Se a psicanálise pode contribuir, de alguma forma, com o campo de educação, terá de apontar para a necessidade de uma postura reflexiva sobre a tarefa de escutar, que supõe uma reconstrução a ser feita pelo professor junto aos alunos. Escutar é dar sentido ao mundo que cerca o 
aluno. Ao escutar os ditos e os não ditos, produzimos e ampliamos o mundo das coisas, damos a nossa versão, que é réplica e não uma repetição.

A escuta da fala do outro é na verdade um diálogo dentro de nós mesmos com as muitas falas que nos constituíram e nos constituem. Escutar e falar faz parte do processo educativo, porém este binômio na escola parece ter pesos diferentes entre os atores.

Esse mundo desejante, que habita diferentemente em cada sujeito, estará sempre preservado cada vez que um professor renuncie ao controle e aos efeitos de seu poder sobre o aluno. "Matar o mestre - para falar, escutar e tornar o mestre de si mesmo - é uma lição que precisa ser ressignificada" (KUPFER, 2000, p. 45).

Se, por um lado, Freud foi de fato um antipedagogo; por várias razões, foi um mestre da educação. Seu jeito peculiar de fazer teoria revelou a singular relação que tinha com o ato de pensar, falar e escutar. Freud pensou com a mente e com o desejo, e, talvez por isso a fala e a escuta tenham ocupado um lugar singular no seu modo de educar. Neste sentido o mestre nos convida a pensar:

A psicanálise já encerra em si mesma fatores revolucionários suficientes para garantir que todo aquele que nela se educou jamais tomará em sua vida posterior o partido da reação e da repressão. Penso até mesmo que as crianças revolucionárias não são desejáveis, sob nenhum aspecto (FREUD, 1976, p. 348).

As conexões da psicanálise e educação precisam ser ainda estabelecidas. Mas, talvez, desde já, a psicanálise possa oferecer à educação um outro olhar, não narcísico, não tão etnocêntrico, mas um olhar em que o professor se coloca no lugar daquele que investiga, daquele que questiona o saber fechado, previamente estruturado do aluno.

Em meio a toda impossibilidade de se casar a psicanálise com a educação, é certo que ambas começam a se olhar. Nesse caso, estão abertas as portas para que o saber da representação social tome lugar entre esses dois saberes, mostrando ao leitor o que podemos ver por detrás dele, sem, contudo, conduzi-lo para dentro, porque educar segundo Freud, parece ser mesmo uma tarefa difícil.

Após discorrer sobre as relações entre psicanálise e educação faz-se pertinente encontrar um ritmo, um compasso entre representação social e psicanálise. Nesse sentido, Kaes (2001 apud JODELET, 2001, p. 67- 68) diz: 
A psicanálise é, ela própria, objeto de representação social. De fato, foi em relação a ela que S. Moscovici (1960) definiu o próprio conceito de representação social e seu método de estudo. [...] É pouco provável que os dois objetos coincidam, pois se constituem de projetos, epistemológicos diferentes e práticas diferentes; mas é possível que ligações pouco evidentes se desvelem.

Por este caminho é possível tentar percorrer uma trilha demarcando que tanto a representação social quanto a psicanálise e a educação foram e são influenciadas pela cultura. É nesse contexto que educação, representação social e afetividade são convidadas a comparecer neste estudo, entendendo que essas áreas engendram-se no desfiladeiro da cultura, sendo a palavra "cultura" pode ser entendida como:

$\mathrm{O}$ resultado de tudo o que o homem produz para construir sua existência. No sentido amplo, antropológico, cultura é tudo o que o homem faz, seja material ou espiritual, seja pensamento ou ação. A cultura exprime as variadas formas pelas quais os homens estabelecem relações entre si e com a natureza (ARANHA, 1996, p. 14-15).

Desse modo, pode-se resgatar que a psicanálise contribuiu para se pensar a afetividade na educação, que está presente de mil maneiras na cultura e na vida cotidiana. Estas concepções são em si mesmas uma parte da cultura contemporânea, tanto no plano científico-filosófico quanto no efeito que essas posições teóricas têm sobre os costumes, as idéias, o senso comum e a própria civilização.

É pela trilha da cultura que é possível mapear pontos em que a representação social e a afetividade se engendram no contexto da sala de aula. Sabemos o quanto a sala de aula é produtora de cultura, de relação e comunicação e, por sua vez, é um espaço de construção das representações sociais.

Pode-se afirmar que tanto a afetividade contribui com a educação, para desvelar os aspectos afetivos do desenvolvimento, quanto a teoria das representações sociais reconhece igualmente a importância desses aspectos. Desse modo Jodelet (1989, p. 41), acrescenta:

As representações sociais devem ser estudadas, articulando elementos afetivos, mentais e sociais e integrando ao lado da cognição, da linguagem e da comunicação, as relações sociais que afetam as representações e a realidade material, social, ideal sobre as quais elas intervirão. 
A escola pode se constituir num espaço no qual a construção das relações afetivas acontece e, ao mesmo tempo, é onde acontecem a fala e a escuta. Uma fala bem elaborada pode ser escutada, trocada e analisada, na prosa da sala de aula, na prosa da relação. É nesse lugar que se encontram os dois sujeitos: o professor e ao aluno. Ambos são portadores de uma fala, de uma escuta e das representações que as sustentam.

Logo, pode-se dizer que a representação social de professores (sujeito) sobre fala e escuta (objeto) constitui um leque de possibilidades para que se perceba um novo olhar sobre a sala de aula, no que se refere à relação professor/aluno.

Vale pontuar que os campos das representações sociais, da educação e da afetividade encontram-se no centro de um debate interdisciplinar, na medida em que se tenta nomear, fazer relações entre as construções simbólicas com a realidade social e dirigem seu campo epistêmico para entender como esta realidade constrói a leitura dos símbolos do nosso cotidiano que nos movem à ação. Na condição de pesquisadora, pergunto: não seria essa capacidade de dar uma nova forma às coisas pela atividade psíquica que constitui uma representação social?

Kaes (2001), ao pensar sobre representação social numa vertente psicanalítica, elabora a hipótese de que a representação é um trabalho de lembranças daquilo que está ausente, que está em falta. Portanto, a representação, assim como a psicanálise, indica uma ausência, se forma como traço e reprodução de um objeto perdido.

Representação social, educação e afetividade são como a imagem do tecelão, alguns fios parecem partidos, outros estão unidos desenhando em seu trajeto uma peça necessariamente interminável. Então, posso suspirar mais aliviada ante o esforço feito de encontrar na cultura um caminho por meio do qual representação social e psicanálise se encontram, mesmo sabendo que a incerteza atormenta o laço possível.

A amarração entre representações sociais, educação e afetividade é feita a partir da convivência, das interações, da partilha e das trocas entre os sujeitos desejantes que estão na sala de aula na busca da construção do conhecimento.

Diante dos passos construídos, minha argumentação é de que as representações de afeto de professores em sala de aula vão além da 
transmissão de conteúdos, mas se revestem de subjetividades em que os afetos não são vistos apenas no campo do prazer (alegria, realização, satisfação, etc.), mas também no campo do desprazer, como luto, tristeza, desatenção, etc. O professor e o aluno possuidores da sua cultura e da sua história, desenvolvem relação consigo mesmo, com o outro e com o mundo, e essas dimensões estão (entre) laçadas na sala de aula. Com vistas a elucidar que o afeto está simbolizado pelo Eros e Thanatos, os mestres da psicanálise nos ajudam a compreendê-lo como "um dos estados emocionais, cujo conjunto constitui a gama de todos os sentimentos humanos, do mais agradável ao mais insuportável" (FREUD, 1894, p. 124).

Essa maneira bivalente de conceituar afeto, sem dúvida, representa um avanço no conhecimento sobre a temática, na medida em que desnuda a idéia de que o afeto encontra-se ancorado apenas nas situações ditas prazerosas. No entanto, ao mesmo tempo, torna cada vez mais precisa a necessidade de transpor o nível de constatação, seja do que se passa no cotidiano da sala de aula, seja do que ocorre no imaginário do professor e do aluno. Para Lacan (1978), o sujeito é marcado pela falta, seus afetos estão enodados no prazer e no desprazer.

Construímos, como professores, nossas próprias representações e, em razão delas, orientamos nossas atividades e as impomos ao aluno, na suposição de que sabemos o que é melhor para ele. Conhecer as representações sociais dos professores constitui uma boa trilha para nos ajudar a ajustar com maior visibilidade o quanto a fala e a escuta em sala de aula podem contribuir na eficácia do projeto pedagógico da escola.

É possível dizer que a citação que principia essa escrita revela a história da educação, de como vem sendo bordada, levando-se em conta as cores quentes e frias dos fios da afetividade através das representações e estas expressam o relevo, ou seja, o que vejo e o que não é possível ver, e este movimento de falta tem origem no senso comum e na vida cotidiana.

Enquanto pesquisadora, me constituo enquanto sujeito da falta e me coloco também no lugar da fala quando tento apresentar o risco de não poder na sua completude enodar educação, representação social e afetividade, mas sinto-me (in)satisfeita de tentar dar forma a esse desejo, na busca de amarrar e desatar e amalgamar os fios quebrados do material 
teórico e empírico a ser tecido. O desenho a seguir mostra simbolicamente como deve ser construído esse enlace:

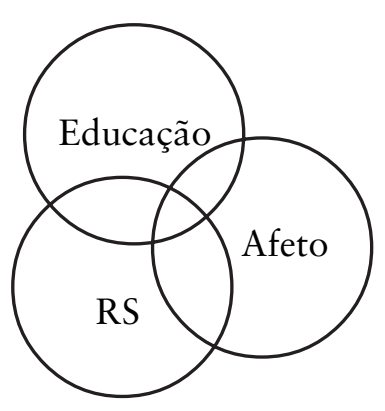

Enlaçar educação, representação social e afetividade é ousar a uma escuta da interface que deve ser construída nas relações do processo educativo que acontece na escola. Esse tripé possibilita pensar o processo ensino/ aprendizagem e sua interseção com os dois sujeitos: professor e aluno. Ambos trazem para o contexto escolar seus afetos. Estes podem ser conceituados como já foi visto como estados emocionais, cujo conjunto constitui a gama de todos os sentimentos do sujeito, do mais agradável ao mais insuportável.

Para não concluir, convido o leitor a fazer o risco e começar o bordado. A cor da linha é uma opção de cada um. A forma tem lugar na sua singularidade. $\mathrm{O}$ tamanho da agulha constitui-se de significante porque pode ter furos. Mesmo assim, corre-se risco e é aqui que se encontra o ágalma. ${ }^{1}$

\section{REFERÊNCIAS}

ARANHA, M. L. de A. Filosofia da educação. São Paulo: Moderna, 1996. ARRUDA, A. (Org.). Representado a alteridade. Petrópolis: Vozes, 1998.

FARR, Roberto M. As raizes da psicologia social moderna. Petrópolis: Vozes, 1998.

FREUD, S. Obras completas. Rio de Janeiro: Imago, 1976. (Volumes 3, 7, $9,10,22)$

Objeto de desejo, brilhante, galante, termo que vem do gal, brilho no antigo francês e Lacan utiliza esta palavra no Seminário 8 - A transferência. 
FREUD, S. Obras completas. Rio de Janeiro: Imago, 1976. (Volumes 3, 7, 9, 10, 22) 1 CD ROM.

IBAÑEZ, G. T. Representacionies Sociales, teoría y método. In: IBAÑEZ, G. T. (Coord.). Ideologías de la vida cotidiana. Barcelona: Sendai, 1988.

JODELET, D. (Org.). As representações sociais. Rio de Janeiro: Eduerj, 2001.

(Dir.). Les Représentations sociales. Paris: Presses Universitaires de France, 1989.

KÄES, R. Psicanálise e representação social. In: JODELET, D. (Org.). As representações sociais. Rio de Janeiro: Eduerj, 2001.

KUPFER, M. C. Educação para o futuro: psicanálise e educação. São Paulo: Escuta, 2000.

LACAN, J. Função e campo da fala e da linguagem em psicanálise. Rio de Janeiro: Perspectiva, 1978.

LANE, S. T. M. Usos e abusos do conceito de representação social. In: SPINK, M. J. (Org.). O conhecimento no cotidiano: as representações sociais na perspectiva da psicologia social. São Paulo: Brasiliense, 1993, p. 58-72.

MOSCOVICI, S. A representação social da psicanálise. Rio de Janeiro: Jorge Zahar, 1978.

ORNELLAS, M. L. S. Imagem do Outro (e) ou Imagem de si?. Salvador: Portfolium, 2001. Afetos manifestos na sala de aula. São Paulo: Annablume, 2006.

OUTEIRAL, J.; CEREZER, C. Adolescer: estudos sobre adolescência. Porto Alegre: Artes Médicas, 1994.

SOARES, Magda. Metamemoria-Memórias: travessia de uma educadora. São Paulo: Editora Cortez,1990.

SOUSA, C. P. Estudos de representações sociais em educação. Revista Psicologia da Educação, São Paulo, n. 14-15, p. 286, 2002. 



\section{Conscientização: uma das estratégias na formação continuada}

Vânia Finholdt Ângelo Leite

Este artigo é fruto de uma pesquisa de mestrado ${ }^{1}$, objetivando analisar a influência das estratégias formativas baseadas na reflexão, resolução de problemas e na conscientização da prática pedagógica ligadas a números e operações e as conseqüentes mudanças da prática pedagógica.

Desde 1996, quando desenvolvia um trabalho de formação continuada em uma escola particular de Salvador, o trabalho estava voltado para o estudo de temas ligados às pesquisas e discussões recentes na área da educação. Entretanto, observava que esses estudos “teóricos” não revertiam em uma prática coerente com as concepções estudadas, muitas vezes, os professores expressavam um discurso compatível com as concepções pedagógicas discutidas, mas sua prática em aula diferia daquelas discutidas nos grupos de estudos.

Então, emergiram as seguintes questões: por que os estudos e concepções teóricas não se revertem em ações na prática pedagógica? Qual seria o formato e quais características teria uma formação continuada que possibilitasse a transposição dos conhecimentos teóricos para a prática de sala de aula?

A partir dessas questões que se formulam as hipóteses do trabalho, tomando como os elementos primordiais os problemas enfrentados pelo

Dissertação intitulada Experimentando estratégias de formação: da reflexão à conscientização sob orientação da Dra Profa Maria Cristina Martins Penido. 
grupo em relação a números e operações, buscando refletir sobre eles de maneira crítica, como sugere Freire (1980, p. 37):

Cada relação de um homem com a realidade é deste modo, um desafio ao qual deve responder de maneira original. Não há modelo típico de resposta, senão tantas respostas diferentes quantos são os desafios [...] É possível encontrar-se respostas bem diversas a um mesmo desafio.

Assim, a formação de professores estará pautada no desvelamento dos problemas por eles enfrentados, pois para solucinoná-los deve-se questionar o que se fez para respondê-los? Pode-se fazer diferente? Que elementos existem para enfrentá-los? A quem se pode recorrer para solucioná-los?

Nesse processo de desvelar os problemas do grupo e buscando solucionálos, os professores estariam mobilizados a construir conhecimentos, pois para resolver as questões da prática precisam refletir sobre os elementos que dificultam e/ou impedem suas ações na sala, como também, buscar nos textos e pesquisas elementos que possam auxiliar na resolução de suas questões.

A partir desse referencial, o professor estaria constituindo-se como sujeito de sua ação, sendo autor de sua prática. Essa construção é fruto de sua reflexão sobre a realidade em que está inserido, pois nas palavras de Tardif (2002, p. 127):

os professores serão reconhecidos como sujeitos do conhecimento quando lhes concedermos, dentro do sistema escolar e dos estabelecimentos, o status de verdadeiros atores, e não o de simples técnico ou de executores das reformas da educação concebidas com base numa lógica burocrática top and down.

O foco desta pesquisa foi, portanto, buscar resolver os problemas enfrentados pelos professores da Escola Educar para Vida², levando em conta suas necessidades, conhecimentos e sua prática pedagógica.

Assim, a pesquisa refletiu sobre os elementos de uma formação que contribuem para a efetiva mudança na prática pedagógica, tendo a questão norteadora: em que medida as estratégias de formação baseadas na reflexão, resolução de problemas e conscientização ligados a números e operações proporcionam a modificação da prática pedagógica?

2 Nome fictício escolhido pela direção da escola. 
Diante dessa questão de pesquisa, buscamos nos referenciar em Alarcão (2000), Scarpa (1998), Tardif ( 2002), Nóvoa (1995).

Nesse texto, nos deteremos com mais detalhes nas contribuições de Paulo Freire que aborda a reflexão visando à conscientização, possibilitando aos professores entenderem os problemas pedagógicos, gerados na sala de aula, e compreenderem o conhecimento como produto social e histórico.

O termo conscientização foi cunhado por uma equipe de professores do Instituto Superior de Estudos Brasileiros em 1964, entre eles, o filósofo Álvaro Pinto e o professor Guerreiro (FREIRE, 1980, p. 25). Sendo difundido por Hélder Câmara que encarregou de traduzi-lo para o inglês e o francês. Conscientização não se restringe à simples tomada de consciência, mas ao desenvolvimento crítico da tomada de consciência que implica ultrapassar a esfera espontânea de apreensão da realidade.

$\mathrm{Na}$ formação, não se separa a pessoa do ser profissional, pois no dia-adia da sala de aula, não basta que os professores conheçam novas teorias no campo das Ciências da Educação, é necessário que eles formulem perguntas sobre situações fundamentais em torno de si mesmo e das tarefas que cumprem. Para Freire (1980, p. 37),

A conscientização é o olhar mais crítico possível da realidade, que a "dês-vela" para conhecê-la e para conhecer os mitos que enganam e que ajudam a manter a realidade da estrutura dominante

Com esse olhar mais crítico, as situações de sala de aula serão visíveis e palpáveis, possibilitando ao professor desvelar o que está por trás de sua prática.

Com isso, a formação parte das condições em que se encontram a escola e os professores, refletindo sobre sua prática, escolhendo e decidindo qual ação poderá acionar a partir daí e se submetendo ou não a determinada imposição. Para Freire (1980, p. 37), são esses movimentos que nos tornam sujeitos, pois

o importante é advertir que a resposta que o homem dá a um desafio não muda só a realidade com a qual se confronta: a resposta muda o próprio homem, cada vez um pouco mais, e sempre de modo diferente.

Nesse sentido, não será pela imposição de uma concepção pedagógica ou de um receituário de atividades que ocorrerá a mudança na prática dos 
professores, mas pela conscientização, colocando-se como sujeitos de suas ações pedagógicas, pois no processo de aprendizagem só aprende quem se apropria do objeto, transforma-o, com o que pode, por isto mesmo, reinventá-lo.

Assim, para Freire a superação ou substituição de uma forma de conhecer por outra ocorre por meio da ação e da reflexão através da problematização, na qual o sujeito busca a explicação e solução, visando transformar a realidade, pela sua própria ação. Desta forma, o indivíduo estaria se apropriando da posição que ocupa aqui e agora, "que resulta descobrir-se em uma totalidade, em uma estrutura, e não preso ou aderido a ela ou às partes que a constituem" (FREIRE, 2002, p. 34).

Para o indivíduo descobrir essa totalidade, demanda conscientização que permite a ele se apropriar criticamente da posição que ocupa com os demais seres no mundo. Esta apropriação crítica os impulsiona a serem sujeitos da transformação do mundo, com a qual se humanizam.

Nesta perspectiva, uma formação pautada na estratégia da conscientização reflete com os professores as suas ações, as atividades e as posturas na sala de aula, respeitando e conhecendo a visão de educação/ mundo desses professores, enfrentando-a e aceitando o fato de que os professores têm uma visão diferente da qual o formador vem propondo e nem por isso é pior ou melhor do que a dele. Ao buscar com os professores a tomada de consciência do que fazem aqui e agora, descobrindo uns com os outros quais as concepções educativas existentes por trás de sua prática através de reflexões de questões, como: o que é proposto pelos teóricos está de acordo com a minha realidade? Qual a relação entre essa proposta e a humanização dos meus alunos? Ou será uma domesticação?

Esse ato de pensar a realidade se dá na comunicação que é uma relação dialógica-comunicativa, na qual a expressão verbal e o sistema de signos lingüísticos têm que ser percebidos entre os sujeitos. Se não houver um acordo em torno dos signos, não poderá haver compreensão entre os sujeitos, o que impossibilitará a comunicação. De acordo com Freire (2002, p. 70),

[...] exige dos sujeitos interlocutores incidam sua ad-miração sobre o mesmo objeto; que o expressem através de signos lingüísticos pertencentes ao universo comum a ambos, para que assim compreendam de maneira semelhante o objeto da comunicação. 
Desse modo, para que ocorra a comunicação verdadeira deve haver a compreensão pelos sujeitos intercomunicantes do conteúdo sobre o qual se estabelece a relação comunicativa. Além disso, não se pode deixar de mencionar que o processo de comunicação não está isento dos condicionantes sócio-culturais.

Por outro lado, se as pessoas na formação não expressarem com os signos lingüísticos comuns, se acham auto-suficientes, ou se fecham à contribuição do outro, temem a superação, ou se acham donos da verdade e do saber, não se estabelecerá um diálogo, conseqüentemente, a formação poderá não atingir seus objetivos.

A dialogicidade começará quando professores e formadores se perguntarem em torno do que vão dialogar, sobre como e por que estão fazendo dessa forma, como e por que substituirão ou não suas ações. Assim, o conteúdo não será uma doação ou imposição de um para os outros, mas uma construção entre eles.

A partir das relações entre professores e os formadores, enquanto travam relações com o mundo e entre si é que ocorrerá a tomada de consciência que "é uma operação própria do homem, resulta de sua defrontação com o mundo, com a realidade concreta, que lhe torna presente como uma objetivação" (FREIRE, 2002, p. 77). A objetivação implica em uma percepção que se encontra condicionada pelos ingredientes da própria realidade.

Dessa maneira, há níveis distintos da tomada de consciência e da conscientização, descritos por Freire (2002) e aqui separados para efeito de melhor compreensão do processo:

$1^{\circ}$ momento descodificação - aquele em que os educandos começam a descrever os elementos da situação vivida por eles, como partes constitutivas de seu todo.

$2^{\circ}$ momento etapa descritiva - a cisão da totalidade ad-mirada ${ }^{3}$. É uma espécie de movimento no qual o sujeito se comporta como se estivesse olhando a realidade de dentro.

3 Ad-miração - é o processo onde o sujeito afasta-se de si mesmo e de seu próprio estado para se ver e para ver o estado em que se encontra (FREIRE, 2002, p. 69). 
$3^{\circ}$ momento - no qual o sujeito, com outros sujeitos, volta à ad-miração anterior, em que abarca a situação codificada ${ }^{4}$ em sua totalidade, a fim de percebê-la como uma estrutura na qual os vários elementos se acham em relação solidária.

$4^{\circ}$ momento - neste o sujeito realiza a análise crítica do que a codificação representa e passa a não mais aceitar as explicações focalizadas da realidade.

Esses momentos são parte do processo da conscientização, dos quais resulta a inserção crítica na realidade pelos homens.

Portanto, a conscientização ultrapassa a mera apreensão do fato, colocando o homem num sistema de relações, dentro da totalidade em que se deu. Assim, percebe-se que ela não acontece em seres abstratos e no ar, mas com os homens na sua realidade, daí não ser de caráter individual, mas social. $\mathrm{Na}$ formação, ela se dá na práxis concreta, na qual "ação e reflexão, solidárias se iluminam constante e mutuamente” (FREIRE, 2002, p. 80).

Desse modo, a formação não se baseia na transferência de conhecimentos dos formadores para os professores. A tarefa do formador seria a de problematizar, com os professores, os conteúdos originários de uma aula, de um exercício elaborado por eles, refletindo sobre esse fazer, e para que juntos possam compreender o que está por trás dessa prática. Isso porque, "a educação problematizadora se faz, assim, no esforço permanente através do qual os homens vão percebendo, criticamente, como estão sendo no mundo com que e em que se acham" (FREIRE, 2002, p. 72).

O aqui e o agora da prática dos professores são, pois, os pontos de partida para a tomada de consciência da situação em que vivem, em que se encontram imersos.

\section{CONSTRUÇÃO DA PESQUISA}

$\mathrm{Na}$ busca das respostas ao problema apresentado, foi desenvolvida uma pesquisa qualitativa do tipo pesquisa-ação. Essa pesquisa levou em consideração as idéias e conhecimentos das professoras partindo das suas

Codificação - uma situação existencial, uma situação vivida pelos homens que enquanto a vivem não a ad-miram, apenas se dão conta da situação. 
experiências e das informações coletadas através da mobilização coletiva em torno do estudo dos temas: leitura nas aulas de matemática e o sistema de numeração.

A pesquisa foi realizada na Escola Educar para Vida em Salvador que atende as crianças e jovens da comunidade que freqüentam a rede de ensino. O grupo foi composto pela investigadora, quatro professoras da escola, a coordenadora e a diretora.

$\mathrm{Na}$ primeira fase da pesquisa realizamos entrevistas iniciais, buscando conhecer cada educadora, percebendo-a como profissional, suas relações com o conhecimento matemático e suas dificuldades/anseios em trabalhar com situações-problema.

De posse dessas informações, organizamos e agendamos os encontros grupais de 2004.2 no qual priorizamos: leitura nas aulas de matemática, análise de situações-problema, trabalho de leitura com diferentes tipos de problemas, resolução de problemas através das estratégias pessoais, processo de ensino e aprendizagem na concepção de construção de conhecimento e funcionalidade do planejamento na prática pedagógica.

\section{CONSTRUINDO A FORMAÇÃO CONTINUADA}

Nosso grupo buscava encontrar soluções para as dificuldades dos alunos em ler e interpretar situações-problema nas aulas de matemática. Ao nos debruçarmos sobre o estudo dessas questões, descobrimos outros problemas que precisávamos solucionar como, por exemplo, ligado ao projeto político pedagógico, a concepção de ensino, aprendizagem e ao planejamento.

Nesse sentido, nas reuniões, as discussões com o grupo favoreciam que emitissem suas opiniões relatassem suas aulas e a partir daí, refletimos sobre as dificuldades de aprendizagem das crianças. Assim, nos deparamos com um problema que não é responsabilidade somente das professoras, mas envolve o contexto da escola, seu projeto pedagógico, que explicita os princípios didáticos partilhados, na comunidade escolar. Durante a reunião de 5 de novembro de 2004, quando estávamos discutindo sobre a dificuldade dos alunos da $3^{a}$ série em compreenderem a multiplicação, lançamos uma pergunta ao grupo sobre a proposta da escola:

$\mathrm{V}$ - Mas é isso que eu quero entender. Se você tem um programa e aulas. Se é reforço? 
$3^{a}$ - Mas aí...

V - Não deveria abarcar a dificuldade?

$3^{\mathrm{a}}$ - A gente não tá fazendo esse tipo de reforço. A gente tá fazendo assim. Antes a gente pegava o programa da outra escola e trabalhava em cima daquele programa. O programa da $3^{a}$ série, o programa da $4^{a}$ etc. E trabalhamos com ele.

Ao questioná-las sobre a meta da escola, percebemos que elas estão seguindo um programa da escola regular, desconsiderando o fato de ser uma escola de reforço e que deveria dar ênfase no processo de aprendizagem dos alunos, buscando atender às dificuldades encontradas na sala. No entanto, elas esperavam que o processo de aprendizagem dos alunos se adaptasse ao ensino, não havendo um equilíbrio entre os conteúdos desenvolvidos e o processo de aprendizagem do aluno. Desconsiderando o caminho de aprendizagem que o aluno estava percorrendo e em função disso, não propunham atividades que permitissem a ele avançar do patamar de conhecimentos que já conquistou para outro mais evoluído.

Com a pergunta "aqui não é uma escola de reforço?", buscávamos refletir com o grupo sobre o processo de ensino e aprendizagem, as condições espaço-temporais que a escola está inserida, a influência dela nas dificuldades de aprendizagem das crianças. Enfim, os problemas enfrentados pelo professor não se limitam à sala de aula. Exige olhar a realidade de uma forma crítica, buscando perceber os elementos que mantêm sua prática tal como é, como também, anunciar outros caminhos a partir dessa tomada de consciência. Para Freire (1980), é assim que o homem integra-se ao seu contexto, reflete sobre ele e se compromete, constrói a si mesmo e chega a ser sujeito. Esse encontro acontece através do diálogo, no qual a reflexão e ação são inseparáveis, convidando os homens a se comprometerem com a realidade. Ou ainda nas suas palavras, "a realidade não pode ser modificada, senão quando o homem descobre que é modificável e que ele pode fazê-lo" (FREIRE, 1980, p. 40).

Como esse problema não era de responsabilidade somente das professoras, convocamos a coordenadora e a diretora para discutirmos sobre o fato das professoras estarem seguindo os conteúdos propostos no currículo de cada série sem observar a aprendizagem dos alunos. Isso ocorreu por considerarmos que o processo de formação abrange todos da escola, 
não adianta uma professora mudar suas concepções e práticas se a direção e a coordenação não acompanharem o processo de formação. Nesse sentido concordamos com as idéias de Nóvoa (1995) e Rui Canário, para os quais a formação consiste em mudar as escolas e os professores ao mesmo tempo. Para Canário, a escola pode ser comparada a um quebra-cabeça, se mudarmos uma peça só, ela poderá não se encaixar novamente. Rui Canário, em 2000, prestou assessoria as Faculdades Jorge Amado, cujo material foi gravado e transcrito para uso interno da Instituição.

Nesse encontro, evidenciou-se que a coordenadora percebia que a proposta que desenvolvida não contribuía para a construção de conhecimentos pelos alunos. Ela indicava dois pontos para a melhoria dessa situação: a formação do professor e a construção de projetos.

Embora reconheçamos que a formação seja um dos fatores para o sucesso da aprendizagem dos alunos, não é único. O contexto educacional, o projeto educativo explícito e compartilhado pelos membros da escola, quadro estável de professores, planejamento coletivo do trabalho e avaliação contínua são fatores que contribuem para uma educação de qualidade.

A proposta da coordenadora era de que os professores elaborassem os projetos de aprendizagem. No entanto, a construção desse recurso didático e sua utilização não garantem que o professor saia do lugar comum, pois não podemos classificar uma prática de construtivista ou tradicional somente pela utilização de um material, mas pela forma "como" é proposto e se ele reúne certas condições, a exemplo dos alunos que têm problemas a resolver e decisões a tomar em função do que se propõem produzir ou no caso onde a tarefa garante a circulação das informações, os alunos põem em jogo o que sabem e pensam sobre o conteúdo (WEISZ, 2000). Ou seja, os projetos de aprendizagem podem proporcionar ou não a contemplação desses itens, mas dependerá do saber fazer do professor, e de como realizálo na sala de aula, pois esse saber não é aplicação de conhecimentos "teóricos" sobre como se trabalha com projetos, mas se desenvolve na prática cotidiana.

Além de refletirmos sobre os aspectos macros ligados ao problema que buscávamos resolver, tivemos encontros que focavam no objeto. Assim, em um dos encontros, as professoras começaram a refletir sobre as intervenções e orientações realizadas para ajudar o aluno a compreender as situaçõesproblema. Veja a discussão: 
$1^{\text {a }}$ - Eu falo assim vamos supor: haviam 4 pássaros num galho. Saíram dois. Quantos ficaram? Eles mesmo perguntam: Pró é de mais ou de menos?

Voaram......( dando ênfase) Quantos ficaram?

$3^{\text {a }}$ - Voaram... ( risos porque ela deu ênfase). Tem a dica.

$1^{\text {a }}$ - Aí eu sei.... e fez o problema. Ana tinha 8 balas. Chuparam 3 (fazendo o gesto com a mão). Mãe como eu sei? A mãe repete: Ana tinha 8 balas. Chuparam (repete o gesto) quanto ficaram? Eles perguntam e a gente fica assim... né? Mostrando a eles, não querendo dizer.

\section{Outro relato:}

$2^{\text {a }}$ - Eu boto assim, oh Vânia. Eu deixo eles fazerem. Se eles têm dificuldade. Mexe com um, pergunta pro outro. Eu não sei fazer, eu não sei fazer. Vamos ler o problema, vamos ver a situação e vamos colocar no quadro. Fulano tinha tanto. Quebrou 4. Aí eles dizem...bote tanto. Bote o número. Aí, ganhou não sei quanto. Eu pergunto: como faço agora? Esse número bote embaixo desse. Pronto, pode resolver?(pergunta da prof.) a conta? Prof - Vamos resolver agora? Cç - Falta o sinal. Prof - Qual é o sinal? Cç - Aí, eles dizem. É de mais, é de menos.É o tracinho. Prof - Eu vou lá e coloco. Na hora de resolver, aí que o bicho pega. Como é que eu faço? $6 \times 4$ o que eu boto aqui?

V - Aí, nós estamos no cálculo. E pra fazer resolver essa pergunta: se a gente ta com a intenção de ler pra aprender a ler. Essas estratégias que a gente tá usando não está ensinando o menino a ler. A gente tá dando e os meninos vão continuar com a deficiência em matemática (5/11/04).

A professora $3^{\text {a }}$ série mostrou-se inquieta porque percebeu que induzia os alunos na resolução dos problemas, mas não sabiam o que fazer. Retomamos a questão para o grupo, e a $1^{\text {a }}$ série ao relatar a forma como trabalhava com os alunos se deu conta que não os deixa ler as situações.

No relato da $2^{\text {a }}$ série, notamos que a sua maior preocupação era que o aluno identificasse a operação, o tipo de sinal a ser utilizado e não em proporcionar que de fato entendessem o que estavam fazendo.

Nesse encontro, elas começaram a perceber que induziam a resposta do problema, mesmo não tendo consciência de tal ação. As professoras ficaram 
angustiadas por "descobrirem" que as intervenções da forma que vinham ocorrendo não estavam favorecendo a leitura do problema pela criança. Buscamos aprofundar sobre essa questão, lendo um dos textos de Smole e Diniz (2001), no qual pudemos discutir as sugestões das autoras sobre como se desenvolve uma aula de leitura com as crianças. Elas sugerem que os alunos contem o problema com suas palavras, verifiquem se havia alguma palavra desconhecida, buscando a pergunta e do que se trata o problema. Enfim, questionando e discutindo a situação com a turma para que a compreendessem e não induzindo uma resposta. Logo, cabe ao professor questionar as autoras do texto, "será que isso é viável?”, “será que eu estou de acordo com as autoras?” Essa é a postura de um educador, ler as palavras do texto, analisando o contexto, verificando se essa forma de trabalhar o problema vai tornar o aluno autônomo, ou se ele continuará esperando que indiquem como resolverá a situação. Exercemos nosso direito, quando questionamos os autores estudados, buscando entender o motivo de suas colocações, de sua concepção de educação, enfim, buscando adentrar criticamente no tema.

Em outro encontro, fomos aprofundando sobre o tema nos debruçando sobre as análises das estratégias pessoais que é a oportunidade que o professor dá a criança de demonstrar como pensou e entendeu a situação para resolvêla. Diante de um problema, ela pode resolver utilizando o desenho de pauzinhos, objetos ou os números e algoritmos. Cabendo ao professor analisar essas diversas formas e intervir para que as crianças avancem nas suas estratégias.

Uma das análises que fizemos foi de uma estratégia inventada por quatro crianças para resolver a operação $51 \times 34$, partindo de uma situaçãoproblema. As crianças multiplicaram 51x10, obtendo 510, realizaram essa operação três vezes. Depois, multiplicaram 51 x 4, obtendo 204 e finalmente somaram todos os produtos chegando ao valor 1734 .

Destaco esse trecho da transcrição, porque a análise feita pelas professoras demonstra que não é tão simples e nem fácil olhar sob a perspectiva do outro, percebendo como ele vem pensando para construir seus conhecimentos. Muitas vezes, estamos tão automatizados com uma única forma de resolver as situações, que quando nos deparamos com o diferente, ele nos causa estranheza. Entretanto, se houver uma disponibilidade em aprender com alunos, poderemos aguçar nosso olhar e acompanhar o raciocínio utilizado por eles. Veja a discussão: 
$3^{\mathrm{a}}$ - ...Ele fez 10 vezes 51 e depois ele colocou 510, 510, 510.

$\mathrm{V}$ - Por que? O que ele pensou?

$3^{a}$ - Ele pensou que era trinta vezes que era a dezena, né?

V - Certo.

$3^{\text {a }}$ - Aí faltaria 4 vezes, que ele multiplicaria esse (51) que ele somou de novo. E ele encontrou essa soma. Ele somou e deu o total daqui, né? Foi muito mais complicado pra resolver do que eles fizessem isso daqui? V - Não.

$3^{\text {a }}$ - Você acha que não?

Assim, a professora olhou com a lógica de um adulto que já domina as operações, por isso não compreendia os conhecimentos demonstrados pelo aluno. Na perspectiva da criança, resolver pela estratégia é muito natural, pois traduz o caminho que pensou para encontrar a resposta viável para o problema. Através da análise desses registros, concluímos que o aluno decompôs o trinta e quatro, utilizou a propriedade distributiva, demonstrando que domina conhecimentos matemáticos que são a base para o cálculo escrito.

Assim, nos encontros buscávamos compreender as respostas das crianças, mesmo que a princípio essa análise causasse estranheza pela maneira incomum apresentada, afinal não aprendemos dessa forma e ela difere da maneira convencional e tradicionalmente exigida pela escola.

Discutimos a importância do professor não deixar a criança sempre com as mesmas estratégias pessoais. Cabe a ele desafiar os alunos a buscar estratégias mais elaboradas, socializando-as no quadro, discutindo com eles, como cada um pensou, e solicitar maneiras diferentes de resolver a questão. Para isso, é necessário que o docente planeje suas ações para que os alunos alcancem os objetivos educacionais e a escola cumpra a sua função social. Para isso, nós educadores, precisamos ter clareza do ato político que exercemos, nas palavras de Freire (1999, p. 23),

ter clareza em torno de a favor de quem e do quê, portanto contra quem e contra o quê, fazemos a educação e de a favor de quem e do quê, portanto contra quem e contra o quê, portanto contra quem e contra o quê, desenvolvemos a atividade política. 
O educador não é neutro, isso não significa ser espontaneísta ou manipulador no processo de construção do conhecimento, mas que assuma uma opção e seja coerente com ela na prática.

Selecionei alguns momentos dos encontros para esse artigo, na dissertação o leitor poderá acompanhar o percurso do grupo.

Durante a pesquisa, as professoras foram tomando consciência do papel delas como educadoras capazes de intervir e recriar o processo de ensino. No início, apesar da insatisfação da professoras com os resultados apresentados pelos alunos, apontava-os como os únicos responsáveis. Atualmente, elas descobriram que as intervenções e propostas de trabalho são fundamentais para que as crianças possam avançar do patamar em que se encontram para um nível mais avançado.

Isso ficou evidenciado na entrevista final, através dos depoimentos das professoras que demonstraram uma tomada de consciência dos pontos que precisam ser investidos e modificados. Cabe destacar que não podemos avaliar até que ponto esses conhecimentos se efetivaram na prática, uma vez que não observamos o trabalho de todas as professoras, somente da $3^{a}$ série. Essas modificações, não ocorrerão repentinamente, requerem esforço, reforço, suporte e atenção com todas da equipe.

Esse incentivo, as professoras poderão solicitar da equipe administrativa da escola, uma vez que demonstraram essa abertura participando dos encontros, possibilitando a reflexão sobre a gestão da escola, suas metas e propostas. Chegamos a conclusão de que se o projeto pedagógico não estiver bem definido, cada um poderá agir conforme suas concepções, interferindo no trabalho de todos.

\section{CONSIDERAÇÕES FINAIS}

Ao analisar os dados da formação desenvolvida durante este estudo, pudemos observar de perto a multiplicidade de fatores que envolvem a formação, desenvolvimento e atuação dos professores. Percebemos que a reflexão sobre a ação pedagógica permitiu às professoras a mútua articulação entre teoria e prática, originando uma atuação voltada para a construção de conhecimento. Os saberes teóricos mesclaram-se com os saberes da prática, sendo re-significados e reinterpretados de acordo com sua realidade. 
Um dos fatores que contribuiu para essa re-significação foi o fato de partimos da necessidade apontada pelo grupo, emergindo daí, o conteúdo da formação. Assim, o conteúdo não era transmitido para elas, mas um objeto construído pela equipe.

No decorrer da pesquisa, evidenciou-se que a reflexão sobre a ação não é algo simples e nem rápido de ser construído, requer que o educador tenha espaço, tempo e parcerias com as quais possa compartilhar suas angústias, propostas e atividades. De acordo com os dados analisados, consideramos que houve um espaço respeitoso no qual as professoras se sentiram seguras para socializarem a sua prática, tendo disponibilidade $\mathrm{e}$ abertura para se debruçarem sobre a própria prática tendo-a como objeto de reflexão. "Com a certeza de que sabiam algo e de que ignoravam algo e que se juntavam com a certeza de que poderia saber melhor o que já sabiam e conhecer o que ainda não sabiam" (FREIRE, 1996 p. 153).

Este estudo nos deu indicadores de que a realização de projetos, envolvendo professoras e pesquisadores, pode contribuir para o desenvolvimento profissional das professoras que deles participam. Contribuindo também, para a ampliação do conhecimento da pesquisadora, uma vez que a cada encontro tínhamos que construir uma proposta para que atendesse as dificuldades apresentadas pelos alunos. Estávamos constantemente avaliando as estratégias formativas que seriam mais efetivas para as professoras com as quais estávamos trabalhando, respeitando seu momento e sua trajetória profissional de cada qual.

Percebemos, também, que as professoras estão "sedentas" por encontrarem caminhos para os desafios enfrentados na sala de aula, sendo muito receptivas e comprometidas quando encontram um grupo de formação voltado para escutá-las, apoiá-las, acolhê-las em suas inquietações.

Por outro lado, é essencial que tenham melhores condições de trabalho que possibilite a reflexão e a pesquisa. A escola se constitua em um espaço democrático de análise permanente de suas práticas com seus pares e com o grupo, como também, requer uma política que transforme as jornadas em integrais elevando o salário a patamares dignos de um profissional da educação. 


\section{REFERÊNCIAS}

ALARCÃO, Isabel (Org.). Formação reflexiva de professores estratégias de supervisão. Porto (Portugal): Porto Editora, 2000.

FREIRE, Paulo. Conscientização: teoria e prática da libertação uma introdução ao pensamento de Paulo Freire. 3. ed. São Paulo: Moraes, 1980. - Pedagogia da autonomia, saberes necessários à prática educativa. São Paulo: Paz e Terra, 1996.

A importância do ato de ler: em três artigos que se completam. 38. ed. São Paulo: Cortez, 1999. 2002. . Extensão ou comunicação? 12. ed. Rio de Janeiro: Paz e Terra,

NÓVOA, Antonio (Org.). Os professores e sua formação. 2. ed. Lisboa (Portugal): Dom Quixote, 1995.

SCARPA, Regina. "Era assim, agora não"... uma proposta de formação de professores leigos. São Paulo: Casa do Psicólogo, 1998.

SMOLE, Kátia Stocco; DINIZ, Maria Ignez (Org.). Ler, escrever e resolver problemas: habilidades básicas para aprender matemática. Porto Alegre: Artmed Editora, 2001.

TARDIF, Maurice. Os professores enquanto sujeitos do conhecimento: subjetividade, prática e saberes no magistério. In: CANDAU, Vera Maria (Org.). Didática, currículo e saberes escolares. 2. ed. Rio de Janeiro: DP\&A, 2002 .

WEISZ, Telma. O diálogo entre o ensino e a aprendizagem. São Paulo: Ática, 2000. 



\section{Cidadania na formação do professor: desvelando sentidos e finalidades da prática educativa}

Sandra Regina Soares

As tensões provocadas pelo caráter cada vez mais multicultural e multirracial da população de quase todos os países ditos desenvolvidos, o ataque às estruturas do Estado de Bem-Estar Social pela política neoliberal e a perda de credibilidade das instâncias da política instituída são alguns dos aspectos centrais que têm suscitado a intensificação de estudos (BERNARD, 1997; BRUBACKER, 1997; CAPELLA, 2004; CONSTANT, 1998; COUTURE, 2000, etc.) e debates sobre a questão da cidadania, animados por questões filosóficas acerca da posição do sujeito na sociedade contemporânea. No Brasil, a cidadania também emerge como um tema de crescente interesse, variando o enfoque dos estudos de acordo com o período histórico em que esteja sendo avaliado. Por exemplo, no período após o fim da ditadura militar, na década de 1980, as preocupações dos estudiosos estavam voltadas principalmente para a ausência dos direitos políticos. Em outros contextos, como aquele da adoção mais ofensiva pelo governo brasileiro de uma política neoliberal, os autores orientaram suas reflexões sobre as desigualdades sociais, sobre a relação entre cidadania, democracia e participação e sobre a relação entre educação e cidadania.

No bojo desses estudos, diversos autores, entre os quais, Lefort (1987 apud TELLES, 1994), Ferreira (1993) e Chauí (2000) revelam a existência 
de uma tendência do povo brasileiro à aceitação resignada. Essa tendência, sinônima de falta de consciência de ter direito a ter direitos, de ser um cidadão, caracteriza-se pela forma como a sociedade civil percebe e age, em relação às desigualdades e à falta de respeito aos direitos. Como registram Ferreira (1993) e Chauí (2000), de uma maneira geral, essa situação, na qual se encontra a maioria da população brasileira, é percebida com compaixão, mas, sem indignação, isto é, sem reação coletiva e efetiva para transformá-la.

A educação formal, em nosso ponto de vista, poderia constituir um instrumento importante no sentido de romper com o círculo vicioso da tendência à aceitação resignada ou da falta de consciência da cidadania, todavia, diversos estudos apontam para a direção contrária. No que concerne à formação de professores no contexto universitário, Arroyo (2001), Ribeiro (2001), Rinesi (2001) e Silva (2001) indicam a predominância de uma concepção de cidadania intelectualista e cognitivista, centrada no discurso sobre cidadania sem a possibilidade do seu exercício efetivo na sala de aula. O currículo, baseado nessa concepção, não conseguiria preparar os professores para agir de maneira adequada, por exemplo, face aos preconceitos que se manifestam, cotidianamente, nas relações interpessoais que ocorrem, na sala de aula. Acrescentam os autores que a universidade pública adota uma lógica orientada pelas necessidades do mercado, e a conseqüência disso é o afastamento da universidade de uma perspectiva de formação de cidadãos autônomos. Além disso, as práticas educativas, segundo pesquisas diversas (ABUD, 1999; GRIGOLI, 1990; OLIVEIRA, 1996; TANCREDI, 1995), privilegiam a transmissão de um saber livresco, sem espaço para elaboração dos conteúdos pelos estudantes, a avaliação tradicional e posturas autoritárias do professor na relação com os estudantes.

Em resumo, os estudos sobre a formação dos professores, na universidade indicam a existência de uma ligação entre as relações educativas e a formação para a cidadania dos futuros professores, e, que as práticas educativas podem favorecer ou tornar difícil a formação da consciência e de atitudes cidadãs entre os estudantes, futuros professores.

\section{REFLETINDO SOBRE OS SENTIDOS DE CIDADANIA}

O conceito de cidadania reaparece no fim da Idade Média, junto com a noção de individualismo, associado à idéia de liberdade e igualdade e à 
luta liderada pela burguesia contra os privilégios da nobreza feudal, contra a hierarquia e contra a imposição da religião. Assim, o conceito moderno de cidadania é o resultado da articulação, mais ou menos conflituosa, entre o liberalismo e um esforço de adaptação da política e do conceito de cidadania dos antigos $^{1}$ (COUTURE, 2000). A retomada desse conceito, simbolizada pelas revoluções dos Estados Unidos e da França, coincide, portanto, com o fim dos privilégios feudais e dos Estados Confessionais e, ainda, com a constituição do Estado-nação e de sua maneira de governar baseada na democracia representativa (BRUBACKER, 1997; HABERMAS, 1998; SCHNAPPER, 1991). Apesar de ter se constituído historicamente como um princípio universal e de possuir certos traços comuns nas sociedades ocidentais modernas, não é um conceito unívoco. Os diferentes sentidos que lhe são atribuídos, em cada Estado-nação, provêm de condições históricas, políticas, econômicas e culturais próprias a cada contexto e das relações de força que aí se estabeleceram entre os grupos sociais em conflito (SCHNAPPER, 1991).

A cidadania, na concepção de Constant (1998), revela-se como um conceito complexo e multidimensional, ao mesmo tempo, uma realidade de ordem legal, política e social que permitiria orientar o pertencimento à vida coletiva, e um ideal. O autor destaca quatro concepções de cidadania que emanam dos estudos: a cidadania como manifestação da identidade nacional; a cidadania como estatuto jurídico caracterizado pelos direitos (civis, políticos e sociais) descritos por Marshall (1963 apud CONSTANT, 1998); a cidadania como um conjunto de papéis sociais ligados à participação ativa na vida da cidade e a cidadania como conjunto de qualidades morais.

A cidadania também pode ser compreendida, conforme sugere Pagé (2001, p. 41), como "a maneira que as pessoas têm de se conceber como cidadãos”. Em função dessa idéia, ele apresenta quatro concepções: a) a cidadania liberal, que enfatiza a dimensão jurídica dos direitos do cidadão, em especial os direitos civis e os sociais, delegando a participação ativa na vida da cidade aos especialistas, de forma que o cidadão liberal fique livre para agir na esfera econômica e privada; b) a cidadania deliberativa

O conceito de cidadania na Antiguidade grega e romana era caracterizado por uma participação direta dos cidadãos - homens livres - nas decisões políticas, o que demonstra o caráter essencialmente político deste estatuto, e pela ausência de igualdade de direitos, na medida em que nem os escravos nem as mulheres podiam participar desse processo. 
pluralista, que incorpora o regime de direitos, mas valoriza a participação ativa em beneficio dos interesses comuns; c) a cidadania civil diferenciada, que se configura como uma variação da cidadania liberal, na qual os cidadãos têm uma frágil participação política, em contrapartida têm uma forte identificação com pólos identitários infra e supra estatais; d) a cidadania nacional unitária, que preconiza a subordinação dos cidadãos ao modelo identitário majoritário.

A cidadania liberal é a mais difundida, a despeito das variações na forma de sua concretização em cada Estado-nação. Essa concepção de cidadania tem como pano de fundo uma contradição e uma tensão entre a igualdade ideal e a desigualdade concreta, entre a igualdade do direito e a desigualdade da fortuna. Ela sustenta a ideologia do individualismo radical e depende, fortemente, do conceito de propriedade privada (BARBER, 1997). No sentido social e econômico, a desigualdade concreta diante da igualdade formal tem sido minimizada pelo estado de bem-estar social o qual, no novo contexto mundial, é objeto de ataques sistemáticos da parte dos neoliberais e vive um processo de enfraquecimento, que indicam a tendência a um agravamento das desigualdades sociais e a fragilização da cidadania na sua dimensão social. No sentido da participação política, a cidadania freqüentemente apresentada como uma ação política intimamente ligada ao engajamento dos cidadãos na vida pública é, na prática, restrita ao momento do voto. A sociedade, por sua vez, é concebida como constituída de uma coleção de indivíduos isolados que, simbolicamente, no momento "sagrado" do voto, na cabine isolada, tornam-se membros de uma "comunidade de cidadãos", fonte de soberania e de legitimidade política para o Estado-nação (SCHNAPPER, 2000). A importância progressivamente atribuída ao voto, nas sociedades democráticas modernas, revela, como sugere Garrigou (1988 apud SCHNAPPER, 2000, p. 144), que na sua essência, a cidadania liberal é "um princípio de expressão eleitoral no qual o indivíduo é a única unidade pertinente em detrimento de qualquer outra". Assim conduzida, tem-se uma cidadania mais passiva que ativa, mais potencial (referência a um estatuto abstrato) que real (BARBER, 1997), em outros termos, uma cidadania baseada nos direitos jurídicos do cidadão e não em seu poder político (CAPELLA, 2004).

No contexto da globalização e do neoliberalismo, como sugere Bernard (1997), a supremacia triunfante da economia e do poder financeiro tende 
a definir a cidadania pela atitude do indivíduo de produzir, consumir e investir. Esse contexto aponta, ainda, para o esvaziamento do poder do Estado com a transferência de decisões da esfera pública para a esfera privada, que passa a constituir um novo poder supra-estatal, de caráter econômico, que impõe políticas que favorecem o monetarismo, a desregulamentação, o comércio livre, o fluxo de capital desimpedido e a privatização em massa (CAPELLA, 2004). Em síntese, a cidadania caminha para um esvaziamento total de seu sentido social, político e nacional, e o cidadão tende a ser transformado em consumidor, peça passiva de uma engrenagem, instrumento sem possibilidade ou canal de intervenção num sistema cujo controle é mantido por agentes econômicos e financeiros.

Esse momento de crise por que passa o próprio conceito de cidadania, em ressonância à crise que atravessa as sociedades democráticas ocidentais pode ser gerador de visões críticas e inovadoras, e de uma nova concepção de cidadania verdadeiramente democrática e plural, conforme apontam os defensores da cidadania como construção social. Nesse sentido, esse conceito parece não estar esgotado, particularmente no Brasil onde, efetivamente, $o$ estado de bem-estar social não se consolidou. Assumida com um novo sentido, a luta pela conquista da cidadania tem um grande potencial de desmascaramento da política neoliberal, de mobilização, de organização e de articulação social capaz de contemplar a diversidade e a pluralidade, aspectos enfatizado nas análises mais atuais, que pretendem mostrar as mudanças advindas, dentre outros, do processo de globalização.

\section{As CONCEPÇÕES DE CIDADANIA NO BRASIL}

A literatura brasileira apresenta, basicamente, duas concepções de cidadania, as quais recebem diversas denominações. A primeira recebe qualificativos como formalista, restritiva, passiva, excludente, tutelada, controlada, outorgada. A segunda é denominada de substantiva, ativa, estratégia de construção democrática. Neste estudo adotamos as denominações: cidadania de direitos restritos e cidadania como construção social. 


\section{A CIDADANIA DE DIREITOS RESTRITOS}

A concepção de cidadania de direitos restritos se expressa desde a primeira Constituição da República Brasileira e foi fortemente inspirada, segundo Moderne (1989), nos ideais liberais. Todavia, esses ideais foram adaptados ao contexto de uma sociedade marcada pela herança de três séculos de escravidão, por uma economia essencialmente agrícola orientada para a exportação e pela predominância da família patriarcal. Os traços mais evidentes dessa sociedade são: uma profunda desigualdade social, um débil grau de coesão e de articulação interna e uma forte subordinação ao Estado. A adaptação dos ideais liberais a esse contexto provocou uma espécie de "esquizofrenia políticojurídica” das instituições, que consiste em proclamar fortemente o valor da regra e do direito no texto da lei e na prática ceder à tentação do autoritarismo e da medida de exceção (MODERNE, 1989). A cidadania de direitos restritos pode ser definida como um conjunto de atributos formais reconhecidos juridicamente como acessíveis a todos os cidadãos igualmente. Assim, ela reduz a condição cidadã à esfera da lei (GENTILI, 2000). Segundo essa concepção, a cidadania é outorgada e controlada pelo Estado. Na prática, o direito político se resume ao direito de voto e o povo é excluído das decisões políticas. Essa concepção tem como principais elementos constitutivos: a negação da noção de direitos, a negação do princípio da soberania política, o civismo como subordinação e o autoritarismo social.

\section{A CIDADANIA COMO CONSTRUÇÃO SOCIAL}

A concepção de cidadania como construção social ganha contornos mais claros na primeira metade da década de 1980 , ponto culminante da crise da ditadura militar, momento em que a sociedade brasileira vive a retomada dos movimentos populares - das mulheres, dos negros, dos ecologistas, etc. - , e dos trabalhadores rurais e urbanos (DAGNINO, 1994). Esses movimentos sociais fizeram emergir a consciência de ter direito a ter direitos e mostraram a possibilidade da constituição de espaços públicos "nos quais sobretudo a dimensão ética da vida social pode se constituir em uma moralidade pública através da convivência democrática com as diferenças e os conflitos que elas carregam" (TELLES, 1994, p. 92). Em conformidade com essa concepção, a concretização dos direitos (civis, 
políticos e sociais) é a base fundamental da cidadania. Sendo isso uma realidade, o reconhecimento dos direitos ultrapassaria o aspecto formal da lei e se traduziria, na prática, de maneira igual para todos os cidadãos, independente das suas condições econômicas, sociais e raciais. Esses direitos seriam conquistados pela ação e pela luta social e política quotidiana, razão pela qual esta concepção atribui uma grande importância aos direitos políticos e à participação ativa e direta, participação que impulsionaria a conquista de outros direitos, principalmente os direitos sociais (GENTILI, 2000). Assim, como afirmava Freire (1978, p. 35),

A liberdade, que é uma conquista, e não uma doação, exige uma permanente busca. Busca permanente que só existe no ato responsável de quem a faz. [...] É condição indispensável ao movimento de busca em que estão inscritos os homens como seres inconclusos.

Pressupõe, como sugere o autor, a superação pelos oprimidos do "medo da liberdade", e a expulsão da "sombra introjetada" dos opressores e das suas pautas. Implica o preenchimento, do vazio deixado a partir dessa expulsão, com outro conteúdo "o de sua autonomia. O de sua responsabilidade, sem o que não seriam livres” (FREIRE, 1978, p. 35).

A cidadania como construção social enfatiza, portanto, a importância da formação de valores e atitudes capazes de tornar os indivíduos cidadãos livres, responsáveis, éticos, autônomos e participativos. Atitudes e valores que se constroem nas relações sociais e não no contexto de práticas “educativas" prescritivas. Isto porque:

Um dos elementos básicos na mediação opressores-oprimidos é a prescrição. Toda prescrição é a imposição da opção de uma consciência a outra. Daí, o sentido alienador das prescrições que transformam a consciência recebedora no que vimos chamando de consciência 'hospedeira' da consciência opressora. Por isto, o comportamento dos oprimidos é um comportamento prescrito. Faz-se à base de pautas estranhas a eles - as pautas dos opressores (FREIRE, 1978, p. 35).

Nessa mesma perspectiva, Capella (2004, p. 164) se refere à “cidadania baseada nos poderes" de movimentos de solidariedade que atuam no domínio público-voluntário capaz de sustentar e completar a limitada "cidadania dos direitos". A novidade dessa "cidadania baseada em poderes", que se espera possa emergir da "Agora pública voluntária e estável”, consistiria em não atribuir apenas a este último a tutela das necessidades sociais reconhecidas em público. 
Enfim, constituem os principais pontos de defesa da cidadania como construção social: o direito a ter direitos; novas formas de sociabilidade e de relações entre o Estado e a sociedade; a participação ativa e direta; a autonomia, o respeito à diferença e às identidades, a solidariedade, a desobediência aos poderes totalitários como valores e atitudes fundamentais do cidadão crítico, participativo e ético.

Neste estudo, assumimos como pressuposto, em consonância com os autores que fundamentam a concepção de cidadania como construção social, que tanto a consciência de cidadania (consciência de ter direito a ter direitos) quanto o usufruto dos direitos estabelecidos juridicamente ainda estão por ser conquistados pela maioria da população brasileira, mediante a ação consciente e solidária dos movimentos sociais, materializando assim a cidadania dos direitos e a "cidadania baseada em poderes". A educação pode contribuir efetivamente com a construção desse novo sentido de cidadania graças, especialmente, ao compromisso político-pedagógico dos professores, traduzido em práticas educativas voltadas para o desenvolvimento integral e a autonomia dos alunos e para o florescimento da solidariedade entre eles (FREIRE, 1998).

A reflexão sobre como a escola e a formação de professores podem contribuir para a construção da consciência de cidadania como construção social pode ser facilitada pela discussão do conceito de "relação com o saber" do aluno, pois, a depender do tipo de "relação com o saber" que o sujeito estabelece, estará se construindo como autor de sua própria história ou, ao contrário, sendo conformado como um sujeito passivo, heterônomo, subserviente.

\section{SOBRe OS SENTIDOS DA NOÇÃO DE “RELAÇÃO COM O SABER”}

De início, é importante entender que a relação com o saber de um sujeito contempla, como nos sugere Larose e Lenoir (1995), as representações evocadas sobre o que é saber e, ao mesmo tempo, as formas de acesso a esse saber. Em outros termos, a noção de "relação com o saber" remete à maneira pela qual o ser humano vivendo em sociedade entra em relação com o real e atribui um sentido à realidade que o impacta.

A "relação com o saber" do aluno tem sua matriz construída no seio da família, através do sistema de expectativas e do jogo de atitudes que esta 
estabelece com a instituição escolar. Faz parte desse processo de construção o lugar e a natureza dos livros na casa, a existência ou não de atitude de leitura, a estimulação da criança à leitura, a visita da família a museus, bibliotecas, etc. Essa relação é também influenciada pela mídia nas suas diversas formas (escrita, audiovisual ou visual). Não se trata de uma relação rígida e estanque, portanto, a educação formal pode e deve contribuir para sua transformação ou manutenção mediante as experiências concretas na sala de aula, na convivência com os colegas e com o professor, que também tem uma relação própria com o saber. No dizer insistente de Freire (1998), o professor, além de respeitar os saberes do aluno, deve promover, sistematicamente, a discussão sobre a razão de ser desses saberes e seus nexos com os conteúdos ensinados, "Por que não estabelecer uma necessária 'intimidade' entre os saberes curriculares fundamentais aos alunos e a experiência social que eles têm como indivíduos?” (FREIRE, 1998, p. 24).

\section{O CONCEITO DE SABER}

J. M. Monteil (1985 apud CHARLOT, 1997) estabelece distinção entre informação, conhecimento e saber. A informação é um dado objetivo exterior ao sujeito que pode ser comprada e estocada em um banco de dados. $\mathrm{O}$ conhecimento é o resultado de uma experiência pessoal ligada à atividade de um sujeito dotado de qualidades afetivo-cognitivas, nesse sentido, ele tem um caráter subjetivo e intransmissível. O saber, apesar de ter um caráter objetivo, supõe uma apropriação (da informação) pelo sujeito assim como se verifica no processo de conhecimento. Mas, de acordo com esse autor, o saber é uma forma de conhecimento livre dos aspectos dogmáticos que tendem a se associar à subjetividade. Dandurant e Ollivier (1991 apud LAROSE; LENOIR, 1995, p. 56) distinguem, também, conhecimento e saber, termos que, segundo eles, são freqüentemente confundidos. Para esses autores, o conhecimento, compreendido como toda apreensão simbólica da realidade, é uma noção mais ampla que aquela de saber. Este último supõe uma apreensão mais restrita do real "que obedece a racionalidade científica e é submetido a procedimentos definidos de verificação; ou ainda, a noção de saber é empregada na medida em que ela remete a conhecimentos mais próximos da prática e tornam-se, no limite, o equivalente de saberfazer" (DANDURANT; OLLIVIER, 1991 apud LAROSE; LENOIR, 1995 
p. 56). Em resumo, o saber supõe uma apropriação, uma construção pessoal do sujeito. Todavia, é importante considerar que existem diferentes formas de ter acesso ao saber, ou seja, várias maneiras de se promover a relação do aluno com o saber.

Segundo Lenoir (2001), é possível afirmar que o saber pode ser o resultado de quatro concepções de "relação com o saber": revelação, contemplação, desvelamento, descoberta e apropriação construtiva. As três primeiras concepções são expressões, com nuances diferentes, da epistemologia positivista do saber e repousam sobre a conviç̧ão que o saber pré-existe ao ser humano e a existência lhe é independente. Essa epistemologia supõe, para o contexto educativo, que a aprendizagem seja concebida, exclusivamente, como um processo de internalização de objetos de saberes, estabelecidos de forma heterônoma. O saber reduz-se a um conjunto de bens de consumo e os alunos tornam-se, ao mesmo tempo, consumidores e receptáculos do saber. E o professor, enquanto portador do saber, pode apresentá-lo em porções, de forma fragmentada.

A quarta concepção de "relação com o saber" aparece como alternativa face às concepções anteriores. Refere o saber como o resultado de uma produção humana, como uma construção realizada por um sujeito vivendo em sociedade. Essa concepção repousa sobre uma epistemologia de tipo dialética e construtivista. No contexto educativo, essa epistemologia concebe que o acesso do aluno ao saber se realiza mediante a apropriação ativa, processo que implica assimilações e acomodações do novo, supondo, freqüentemente, rupturas com as representações iniciais. Essa construção do sujeito pode se fazer, grosso modo, de duas formas. A primeira, através do ensaio e erro empírico realizado pelo sujeito, sozinho ou em grupo, mediado por procedimentos de investigação espontânea, configurando um tipo de ensino baseado em métodos de "auto estruturação cognitiva" e sobre um modo de intervenção estimuladora e desafiante do professor. A segunda forma se produz mediante um processo de objetivação cognitiva mediada por procedimentos de caráter científico e sustentado ativamente pelo professor. Nesse caso, o ensino é baseado em métodos de "interestruturação cognitiva", no qual o formador tem uma função de mediação finalizada, temporária e limitada. 


\section{“RELAÇÃO COM O SABER” COMO RELAÇÃO CONSIGO MESMO}

Analisar a "relação com o saber", como afirma Charlot (1997, p. 60), é estudar o sujeito frente à necessidade e mesmo à obrigação de aprender

[...] para se construir, num triplo processo: de hominização (tornar-se homem), de singularização (tornar-se um exemplar único de homem) e de socialização (tornar-se membro de uma comunidade, com a qual se compartilha valores e onde se ocupa um lugar).

Essa autoconstrução parece ser resultante do esforço natural de todo sujeito para dar sentido a seu contexto e à sua própria história. Através desse processo criador de saber, “o sujeito toma consciência de sua ação e de seus sentimentos, explica para si mesmo os determinantes objetivos e afetivos do seu entorno, e tendo em conta sua percepção do real, seu lugar, sua posição, o sujeito determina sua ação" (BEILLEROT, 1989, p. 194).

Essa tomada de consciência permite, ao sujeito, reconhecer-se e afirmar o que sabe, o que pensa e o que faz, a partir da apropriação consciente do saber que decorre de sua própria experiência. Assim, a questão fundamental é a possibilidade de apropriar, ao máximo, o saber à sua experiência, independente do valor intrínseco de seu conteúdo. A relação do processo criador de saber com o "sabido" é mais importante que apenas o "sabido" do qual sairiam respostas ou soluções. A "relação do saber" como processo criador permite, ao sujeito, ultrapassar a reificação e a fragmentação das coisas que ele sabe. Permite, enfim, sua liberdade de ação, impedindo que ele se torne um objeto manipulável pelos outros e por ele mesmo, ou seja, pelo seu inconsciente (BEILLEROT, 1989). Nesse processo, desempenha papel importante a curiosidade e a criticidade. A curiosidade humana, entendida na perspectiva freiriana, como inquietação indagadora, como inclinação ao desvelamento de algo, como procura de esclarecimento e sinal de atenção e estado de alerta, é uma construção e reconstrução histórica e social. A passagem da curiosidade para a criticidade, compreendida como curiosidade epistemológica apoiando-se em métodos que possibilitam uma aproximação do objeto e conota achados de maior exatidão, não se dá espontaneamente. Assim, “uma das tarefas precípuas da prática educativoprogressista é exatamente o desenvolvimento da curiosidade crítica, insatisfeita, indócil” (FREIRE, 1998, p. 35-36). 
A “relação com o saber" como processo criador é uma forma de assegurar, ao sujeito, o papel de autor de sua própria história, superando a armadilha da imposição de numerosas determinações que a noção direta dessa forma de relação inclui. Assim, se o sujeito não sabe toda a história que ele faz: ele guarda uma consciência, essencial, pois é a sua, do sentido de sua história (BEILLEROT, 1989). Com efeito, a "relação com o saber", refere esse autor "torna-se capacidade de elucidação e de consciência na qual o desejo de saber é o desejo de liberdade" (BEILLEROT, 1989, p. 193), mesmo se essa elucidação não é completamente possível. E esclarece que, considerada como processo criador de saber, é uma relação necessária para cada um agir e pensar. Desenvolver a "relação com o saber" como um processo criador dos alunos supõe considerar o desejo de saber como motor da aprendizagem. Falar dela como processo criador em educação "é convir que os objetos de saber ensinados na escola devem ser investidos de desejo para serem apropriados" (DEVELAY, 1996, p. 45). Em outros termos, para que haja apropriação do saber ensinado, o aluno deve estabelecer com esse saber uma relação afetiva e não unicamente cognitiva, isso significa ser necessário que esse saber faça sentido para o aluno. Fazer sentido equivale dizer que algo (uma palavra, um enunciado, um evento, etc.) tem, para alguém, "relação com outras coisas de sua vida, coisas que ele já pensou, questões que ele se colocou” (CHARLOT, 1997, p. 64). Ademais, "aprender faz sentido em referência à história do sujeito, a suas expectativas, [...] à sua concepção de vida, à sua relação com os outros, à imagem que ele tem de si mesmo e àquela que ele quer apresentar aos outros" (BEILLEROT, 1989 , p. 85).

Cabe lembrar que a origem do autoconceito, é social, portanto, as interações com outros significativos são fundamentais na construção, de forma um tanto inconsciente, das apreciações sobre si mesmo, e que, na "relação com o saber", a autopercepção e a autovalorização são essenciais. Assim, a expectativa positiva, a escuta atenta e empática, a abertura para o diálogo, o conflito cognitivo baseado na amorosidade são atitudes do professor que legitimam o desejo de aprender do aluno, fortalecem a confiança na sua capacidade, portanto, o autoconceito positivo, quer seja na educação de crianças e jovens ou na educação de adultos (FREIRE, 1998). Esses aspectos nos remetem à idéia da "relação com o saber" também como uma relação com os outros. 


\section{“RELAÇÃO COM O SABER” COMO RELAÇÃO COM OS OUTROS}

Ficou esclarecido anteriormente que a "relação com o saber" como processo criador de saber sobre o real e sobre si mesmo tem como autor um sujeito de desejo. Charlot (1997), entretanto, sublinha que esse desejo não pode ser tomado numa perspectiva biologicista, associado à pulsão, associação que permite pensar o psiquismo sem referência a outro sujeito. Por tal razão, acrescenta esse autor: "não existe desejo sem objeto de desejo. Este objeto, em ultima análise, é sempre o outro" (CHARLOT, 1997, p. 53). Ademais, o desejo se constitui como tal, e assim faz sentido, para o sujeito que está, ao mesmo tempo, "em busca de si e aberto ao outro e ao mundo" (CHARLOT, 1997, p. 55). Como enfatiza esse autor, é a condição humana, que se estabelece a partir da coexistência e da troca, que faz de um indivíduo um sujeito desejante e criador do saber sobre si e sobre o real. “Toda relação consigo mesmo é também uma relação com o outro, e toda relação com o outro é também relação consigo" (CHARLOT, 1997, p. 52). É importante destacar que o outro não tem, necessariamente, uma presença física, "É o outro como forma pessoal da alteridade, como ordem simbólica, como ordem social [...]" (CHARLOT, 1997, p. 51). Isso significa que o processo criador de saber deve ser considerado como um processo individual e, também, coletivo, no mínimo como processo de grupo (BEILLEROT, 1989). Em síntese, conforme Beillerot (1989), os microcosmos dos grupos constituem uma interface inevitável entre a dinâmica individual e o movimento coletivo e social, tendo, então, uma importância fundamental na vida do sujeito e na constituição de seu psiquismo, análise que conduziu Freud a definir o indivíduo como um grupo interiorizado. O processo criador de saber sobre o real e sobre si desenvolve-se, como vimos anteriormente, numa rede de relações na qual o aluno está em relação com outros alunos. Assim, o professor preocupado em facilitar uma "relação com o saber" como processo criador deve levar em conta que essa relação depende, também, do contexto no qual se produz a relação com os outros alunos. Razão por que lhe compete estimular o questionamento, a reflexão critica sobre as próprias questões dos alunos, sobre as opiniões dos colegas (DAYRELL, 2001; FREIRE, 1998; SANTOMÉ, 1997). O relacionamento com os outros implica relação com as regras de convivência e de civilidade. 


\section{“RELAÇÃO COM O SABER” COMO RELAÇÃO COM AS REGRAS}

As regras de convivência na sala de aula, em outras palavras, os direitos e deveres de cada um, os limites, a disciplina, as regras de convivência na sala de aula devem ser construídos e reconstruídos coletivamente pelos estudantes e pelo professor (DEVELAY, 1996; FREIRE, 1998). Assim, as regras do grupo, o saber sobre o real, os valores e atitudes éticos na relação com o outro se constroem, simultaneamente, na sala de aula, com a mediação do professor. Esse processo contém um potencial educativo, igualmente um potencial psicossocial, na medida em que se engajar na construção das leis do grupo é conseguir renunciar ao narcisismo para entender e contemplar o desejo dos outros. Develay (1996, p. 81) avalia que a "única maneira de estar totalmente num grupo é poder se distanciar dele analisando os riscos da fusão”. As regras construídas coletivamente garantiriam as condições favoráveis à manutenção do sujeito são no grupo; elas constituiriam, então, uma terceira presença estrategicamente colocada na relação de cada sujeito com os outros. Sem construção coletiva das regras, todo esforço educativo torna-se apenas condicionamento a regras prescritas de forma heterônoma, adverte o mesmo autor.

Coordenar o processo coletivo de construção das regras de convivência, na sala de aula, implica para o professor que, conscientemente ou não, se orienta pela concepção de cidadania como construção social, aceitar colocar em questão seus desejos, implica escutar e, concretamente, levar em conta os desejos dos alunos, tendo como meta a criação de um contexto favorável para aprender e viver em conjunto. Implica, ainda, aceitar "renunciar à relação senhor-escravo e desenvolver uma relação educativa baseada em uma relação de confiança e não em uma relação de autoridade carismática ou mesmo de competência” (DEVELAY, 1996, p. 111).

O professor consciente dessa verdade estará sempre empenhado em facilitar as relações entre os estudantes, contribuindo para eliminar, através da reflexão e não do sermão e da prescrição do "dever-ser”, os problemas relacionais que emergem no cotidiano da sala de aula (DAYRELL, 2001; FREIRE, 1998; SANTOMÉ, 1997). Importa ter em mente que a formação de sujeitos autônomos, no processo educacional pressupõe levar em consideração a complexidade do grupo-classe, carregado de histórias e determinado pela dinâmica da vida afetiva. Uma relação educativa que 
não perca de vista tais aspectos estará valorizando os estudantes como portadores de direitos e, além de oferecer um lugar para sua expressão, estará possibilitando que se construam referências comuns nos domínios dos valores e das práticas que os concretizam. Além disso, no processo de avaliação se acordariam aos estudantes oportunidades de auto-avaliação e de reflexão sobre suas aprendizagens cognitivas e suas atitudes (DAYRELL, 2001; PIMENTA; ANASTASIOU, 2002), o que concorreria para a aprendizagem da responsabilidade, da tomada de decisão, enfim, da autonomia (FREIRE, 1998). Os estudantes seriam também convidados a participar da avaliação do professor, de sua metodologia e de suas atitudes na sala de aula.

Pode-se concluir com Develay (1996) que toda relação com o saber como processo criador é, ao mesmo tempo, "relação com o saber", relação consigo mesmo, relação com os outros e relação com as regras/leis e com o poder. Nesse sentido, como sugere esse autor, para garantir uma aprendizagem significativa, o professor precisa compreender e, se for o caso, contribuir para transformar o tipo de "relação com o saber" e de relação com as regras e com o poder que adotam seus alunos. Assim, uma "relação com o saber" que não seja, de início, uma relação de rejeição, mas, sim, de adesão, constitui uma condição prévia para a aprendizagem, e uma relação com a lei que não seja de submissão e, sim, de adesão, constitui condição indispensável para a aquisição do saber.

ENTRELAÇANDO AS REFLEXÕES SOBRE CIDADANIA E "RELAÇÃO COM O SABER": À GUISA DE CONSIDERAÇÕES FINAIS

Os elementos sumariamente apresentados no decorrer desta exposição indicam que cidadania adquire sentidos diferentes nas diversas sociedades (em decorrência das condições históricas, políticas, econômicas e culturais próprias) e, também, no interior de cada sociedade, por parte dos diferentes grupos e classes sociais, haja vista as duas concepções de cidadania, no caso da sociedade brasileira. Além disso, é um conceito complexo e multidimensional, que incorpora, de um lado, uma realidade material de ordem legal (estabelece direitos e, conseqüentemente, deveres), política (depende das relações de poder, atravessadas por interesses econômicos, e da correlação de força dos segmentos e grupos em conflito) e social (expressa-se na cultura 
e nas relações entre pessoas e grupos no convívio social). De outro lado, um ideal que estabelece um conjunto de atitudes e valores relacionados à, maior ou menor, participação dos indivíduos na coletividade, em prol do bem comum.

Em síntese, é um conceito que articula as dimensões: direitos, participação e valores e atitudes. Atitudes, por exemplo, em relação ao seu contexto, em relação aos outros, em relação às leis e em relação ao poder, que são construídas nas interações com os outros significativos, no seio da família, da escola e por influência da mídia.

A contribuição da educação formal, em especial da formação de professores, para a construção da consciência de cidadania, para a formação de um sujeito e cidadão crítico, participativo e ético pressupõe práticas educativas que promovam a "relação com o saber" do aluno como um processo criador. Essa forma de relação, como vimos anteriormente, implica, além da relação do sujeito com o saber, a relação consigo mesmo, com os outros, com as regras e com o poder. Assim, esses dois conceitos, embora com amplitudes diferentes, o primeiro se situa no contexto macro das relações na sociedade e o segundo, embora transcenda o ambiente da educação formal, na perspectiva tomada neste estudo, situa-se no contexto micro da sala de aula, mantêm entre si uma relação de interdependência e complementaridade.

As considerações que se vêm de fazer levam à compreensão de que práticas educativas heterônomas, centradas na transmissão bancária de conteúdos acadêmicos fragmentados, dogmatizados e descontextualizados do ponto de vista social, político e histórico, sem as controvérsias e variações já produzidas sobre o fenômeno em questão e, ainda, desconectados dos demais conteúdos da disciplina, da realidade e da prática educativa dos estudantes (GRÍGOLI, 1990; PIMENTA; ANASTASIOU, 2002; SANTOMÉ, 1997); baseadas em relações professor-aluno fortemente hierarquizadas, autoritárias e destituídas de afetividade positiva se entrelaçam com a concepção de cidadania de direitos restritos e contribuem para a reprodução da tendência à aceitação resignada, da falta de consciência de cidadania.

Em contrapartida, práticas educativas capazes de desenvolver uma "relação com o saber" de forma construtiva, criadora, crítica, reflexiva e cooperativa contribuem para a construção da consciência de cidadania, 
concorrem para a formação de valores morais e éticos necessários ao exercício da cidadania como construção social. Assim, a noção de "relação com o saber" como processo criador contribui para a formação da cidadania como construção social, pois, como sugere Beillerot (1989), situar o processo criador como definidor da "relação com o saber" é uma forma de assegurar, ao sujeito, o papel de autor de sua própria história.

A reflexão sobre os conceitos de cidadania e de "relação com o saber" ainda é muito restrita e incipiente no contexto da formação de professores, entretanto, consciente ou não, os formadores de professores têm representações sobre esses conceitos. Representações compostas de informações, crenças, atitudes, que são construídas e compartilhadas socialmente e, conseqüentemente, como formulou Moscovici (1976), orientam suas práticas educativas, pois, como sabemos, as conviç̧ões existenciais, os valores e visões de mundo e de relação com o mundo, enfim a concepção de ser social e de cidadão que se quer contribuir para formar é subjacente à escolha dos saberes a ensinar e das práticas adotadas que levem os alunos a ter acesso ao saber. A discussão sobre esses conceitos e sobre o entrelaçamento dos mesmos no contexto da formação de professores pode contribuir para o processo de reflexão crítica dos formadores de professores, na universidade, sobre suas próprias práticas, a partir do reconhecimento, como nos ensinou Paulo Freire (1998, p. 146), de que a educação é um ato político e ideológico, o que nos convoca a encerrar estas reflexões com palavras de sua autoria, que trazem elementos sempre atuais para sustentar o sentido da cidadania com o qual trabalhamos aqui: "Tenho afirmado e reafirmado o quanto realmente me alegra saber-me um ser condicionado, mas capaz de ultrapassar o próprio condicionamento".

\section{REFERÊNCIAS}

ABUD, Maria José. Professores de ensino superior: Características de qualidade. Taubaté. 1999. 278 f. Tese (Doutorado em Educação) - Pontifícia Universidade Católica de São Paulo, São Paulo, 1999.

ARROYO, Miguel. A universidade e a formação do homem. In: SANTOS, G. (Org). Universidade formação cidadania. São Paulo: Cortez, 2001. p. 33-50. 
BEILLEROT, Jacky. Le rapport au savoir: une notion en formation. In: BEILLEROT, J.; BLANCHARD-LAVILLE; BOUILLET; MOSCONI. Savoir et rapport au savoir-élaborations théoriques et cliniques. Paris: Éditions universitaires. 1989, p. 165-202.

BARBER, Benjamin. Démocratie forte. Paris: Desclée de Brouwer, 1997.

BERNARD, Michel. L'Utopie Néolibérale. Québec: Éditions du Revouveau quebecois et chaire d'études socio-économiques de l'UQAM, 1997.

BRUBACKER, Roger. Citoyenneté et nationalité en France et en Allemagne. Paris: Belin, 1997.

CAPELLA, Juan-Ramón. Globalização, o Desvanecimento da Cidadania. In: BURBULES; TORRES (Org.). Globalização e educação. Perspectivas críticas. Porto Alegre: ARTMED, 2004, p.153-167.

CHAUI, Marilena. Brasil: mito fundador e sociedade autoritária. São Paulo: Editora Fundação Perseu Abramo, 2000. (Coleção História do Povo Brasileiro).

CHARLOT, Bernard. Du rapport au savoir. Élements pour une théorie. Paris: Ed. Economica, 1997.

CONSTANT, Fred. La citoyenneté. Collection Clefs Politique. Paris: Montchrestien, 1998.

COUTURE, Y. À l'ombre de l'individu. In: POTVIN; FOURNIER et COUTURE (dir.). L'individu et le citoyen dans la société moderne. Canadá: Presses de l'Université de Montréal, 2000, p. 15-38.

DAGNINO, Evelina. Os movimentos sociais e a emergência de uma nova noção de cidadania. In: DAGNINO (Org.). Anos 90. Política e sociedade no Brasil. São Paulo: Brasiliense, 1994, p. 103-115.

DAYRELL, Juarez. A escola como espaço sócio-cultural. In: DAYRELL, Juarez (Org.). Múltiplos olhares sobre educação e cultura. 3. ed. Belo Horizonte: Ed. UFMG, 2001, p. 136-161.

DEVELAY, Michel. Donner du sens à l'école. Collection Pratiques et enjeux pédagogiques. Paris: ESF Editeur, 1996.

FERREIRA, Nilda Teves. Cidadania uma questão para a educação. Rio de Janeiro: Nova Fronteira, 1993.

FREIRE, Paulo. Pedagogia do oprimido. 5. ed. Rio de Janeiro: Paz e Terra, 1978.

- Pedagogia da autonomia. Saberes necessários à prática educativa. 8. ed. São Paulo: Editora Paz e Terra, 1998.

GENTILI, Pablo. Qual educação para qual cidadania? Reflexões sobre a formação do sujeito democrático. In: AZEVEDO, J. C. et al. Utopia e democracia na educação cidadã. Porto Alegre: UFRGS/Secretaria Municipal de Educação, 2000, p. 143-156. 
GRÍGOLI, Josefa Aparecida. A sala de aula na universidade na visão de seus alunos: um estudo sobre a prática pedagógica na universidade. 1990. 251f. Tese (Doutorado em Psicologia da Educação) - Universidade de São Paulo, São Paulo, 1990.

HABERMAS, J. L'intégration républicaine. Essais de théorie politique. France: Fayard, 1998.

LAROSE, François; LENOIR, Yves. L'interdisciplinarité didactique au primaire: Étude de l'évolution des représentations et des pratiques chez des titulaires du premier cycle du primaire dans le cadre d'une recherche-actionformation.. Laboratoire de recherche interdisciplinaire em didactique des disciplines. Sherbrooke: Faculte d'éducation Université de Sherbrooke, 1995. Rapport final.

LENOIR, Yves. Logiques européenne francophone et nord-américaine et conceptualisation de l'éducation: de la différenciation dans le cadre des États-nations à une tendance à la dissolution dans le contexte de la mondialisation. Université libre de Bruxelles. Faculte des sciences psychologiques et de l'éducation. Licence de sciences de l'éducation, 2001. MODERNE, Franck. La Nouvelle Constitution Brésilienne et le Constitutionnalisme Latino-Américain. In: DIDIER; PIERRE (Org.). La nouvelle république brésilienne. Études sur la Constitution du 5 octobre 1988. Paris: Economica, 1989, p. 11-44.

MOSCOVICI, Serge. La psychanalyse: son image et son public. Paris: Presses Universitaires de France, 1976.

OLIVEIRA, Maria de Fátima Alves de. Avaliação no $3^{\circ}$ grau: um estudo exploratório a partir da concepções de professores e alunos do curso de Licenciatura. 1996. 135 f. Dissertação - (Mestrado em Educação), Universidade do Estado do Rio de Janeiro, Rio de Janeiro.

PAGÉ, Michel. L'éducation à la citoyenneté devant la diversité des conceptions. In: PAGÉ, Michel; OUELLET, Fernand; CORTEZÃO, Luiza (Org.). L'éducation à la citoyenneté. Sherbrooke, Québec: Éditions du CRP, 2001, p. 41- 54.

PIMENTA, Selma; ANASTASIOU, Léa. Docência no ensino superior. São Paulo: Cortez, 2002. (Coleção Docência em Formação - Volume I)

RIBEIRO, Arilda Ines Miranda. Formação educacional: instrumento de acesso à cidadania? In: SANTOS, G. (Org.). Universidade Formação Cidadania. São Paulo: Cortez, 2001, p. 63-73.

RINESI, Eduardo. Universidade reflexiva e cidadania crítica. In: SANTOS, G. (Org.). Universidade Formação Cidadania. São Paulo: Cortez, 2001, p. 87-98. 
SANTOMÉ, Jurjo Torres. Política educativa, multiculturalismo e práticas culturais democráticas nas salas de aula. Revista Brasileira de Educação, n.4, p. 5-26, jan./fev./mar./abr. 1997.

SCHNAPPER, Dominique. La France de l'Intégration. Sociologie de la Nation en 1990. Paris: Gallimard, 1991.

SCHNAPPER, Dominique. Qu'est-ce que la citoyenneté? Paris: Gallimard, 2000.

SILVA, Divino José da. (2001). A formação universitária em tempos de sociedade administrada. In: SANTOS, Gislene (Org.). Universidade formação cidadania. São Paulo: Cortez, 2001. p. 133-147.

TANCREDI, Regina Maria. A formação do professor nos cursos de licenciatura da área de Ciências na UFSCAR: uma análise da questão sob a ótica dos licenciandos. 1995. 260f. Tese (Doutorado em Educação) Universidade de São Carlos. São Carlos, São Paulo. 


\section{O movimento nacional pela reformulação dos cursos de formação do educador: embates na construção de um projeto coletivo de formação}

Zenilde Durli

CONTEXTUALIZANDO O SURGIMENTO DO MOVIMENTO

O Movimento pela Reformulação dos Cursos de Formação do Educador foi organizado no mesmo período da crise que conduziria ao declínio e esgotamento da ditadura militar, iniciado com a posse de Geisel em 1974 e estendendo-se até o término do Governo Figueiredo em 1985. O próprio Regime, como destaca Germano (2005), em função das desavenças no bloco do poder, abre perspectivas à participação da sociedade civil. Assim, a organização da sociedade civil em movimentos sociais ${ }^{1}$ de diversas naturezas, a partir de meados da década de 1970 , conta inicialmente com a participação das classes subalternas e, de forma gradativa, com a incorporação das classes dominantes nas mobilizações contra a ditadura.

No quadro da crescente crise que se desenhava, o Estado redefine sua metodologia de ação, deixando de se centrar na função de “domínio",

\footnotetext{
Conforme Cunha (2005, p. 60),"com o nome de movimentos sociais têm sido chamadas as ações reivindicativas de segmentos de populações urbanas (principalmente) que se caracterizam por reagirem às desigualdades na distribuição dos recursos públicos, nos serviços de abastecimento de água, coleta de esgotos e de lixo, saúde, educação, transporte, energia elétrica, telefone, ou seja, os serviços urbanos que têm a ver com o que se convencionou chamar de qualidade de vida".
} 
pois se vê debilitado diante das mobilizações e começa a considerar, em maior grau, a função de "direção" (GRAMSCI, 1978, p. 87). A conquista das massas era essencial à consecução dos objetivos de adesão ao Regime no sentido de torná-lo hegemônico. Centrada nisso, a sociedade política se utilizava das políticas sociais como instrumento para fazer concessões em troca do apoio e da cooptação da sociedade civil. Entretanto, conforme afirma Germano (2005), o Regime não chegou a alcançar tal hegemonia, caracterizando-se sempre como uma "ditadura sem-hegemonia".

$\mathrm{Na}$ intenção de explicitar os objetivos da abertura, Germano (2005, p. 213) enfatiza uma questão que considera essencial à análise da importância da mobilização da sociedade civil para a redemocratização, qual seja: a principal causa da abertura foram as contradições do próprio aparelho estatal e não uma "exclusiva conquista da sociedade civil". A abertura, nessa direção, não visava à democratização da sociedade, mas a transição de um autoritarismo militar para um autoritarismo civil. Corroborando este entendimento, Cunha (2005, p. 65) afirma que o Estado, "por sua omissão ou por suas políticas anti-democráticas tem sido o verdadeiro impulsionador dos movimentos sociais, ao mesmo tempo em que pode funcionar como elemento de contenção desses movimentos".

A dinâmica social então criada, segundo análise de Germano (2005), introduz uma modificação na metodologia de ação do Estado no que se refere à sua relação com as classes subalternas e, por conseguinte, "há uma mudança na forma das políticas sociais, inclusive na política educacional, conduzindo a estratégias mais sutis de dominação ou mesmo à absorção de interpelações populares na formulação de tais políticas [...]" (GERMANO, 2005, p. 213). As mudanças de forma, por sua vez, remetem às relações entre a sociedade civil e a sociedade política que se estabelecem nos momentos de definição das políticas sociais (CUNHA, 2005; GERMANO, 2005). Ou seja, na intenção de lograr a posição hegemônica, promovendo o alargamento do espaço político, o Estado apontou a possibilidade de "maior" participação da sociedade civil diante do seu poder de regulação.

A política educacional, nesse contexto histórico e social, ganhara, então, novos contornos. Os problemas educacionais passaram, segundo Germano (2005, p. 233) a ser encarados pelo Estado como questões políticas, ao mesmo tempo em que as políticas sociais se revestiram "de uma conotação 
ideológica que as identifica diretamente com uma ação destinada aos 'carentes'" e cujo objetivo manifesto era agir como mecanismo de correção das desigualdades sociais. Os discursos em favor da distribuição de renda e os apelos "participacionistas" que impregnaram os Planos Nacionais de Desenvolvimento (PND), no período 1974-1985, tinham dois interlocutores principais, conforme Germano (2005, p. 233): “as classes subalternas, o povo pobre das periferias urbanas das áreas rurais e, com menor intensidade, uma parte das chamadas classes médias empobrecidas pelas políticas econômicas dos sucessivos governos militares".

Diante da conjuntura vigente na segunda metade da década de 1970, o Regime começa a ser questionado no âmbito das universidades e escolas, e o campo educacional inicia sua organização, impulsionada em grande medida pela oposição à pedagogia oficial e à política oficial dominante (SAVIANI, 1997). Assim, o Movimento dos Educadores (ME) promoveu a criação de entidades e/ou associações educacionais na sociedade civil, representativas de parcelas dos trabalhadores em educação e, ainda, impulsionou a revigoração de outras tantas já existentes que, inclusive, já haviam atuado em momentos políticos importantes da história educacional do país em décadas anteriores. Colaboraram intensamente com esta organização, em meados da década de 1970 e início de 1980, segundo Cunha (2005) e Germano (2005), quatro dessas entidades e/ ou associações, a saber: a Sociedade Brasileira para o Progresso da Ciência (SBPC), a Associação Nacional de Pós-Graduação em Educação (Anped), o Centro de Estudos Educação e Sociedade (Cedes) e a Associação Nacional de Educação (Ande).

A partir de 1974, a SBPC, fundada em 1948 e realizando reuniões anuais desde então, amplia seus eventos para a participação de professores, universitários e pesquisadores de todas as áreas, configurando-se como um espaço de expressão das demandas políticas da sociedade e de oposição ao regime. Em 1978, ano de criação da Anped e do Cedes, os educadores se reuniram em Campinas, no I Seminário Brasileiro de Educação, onde se questionou veementemente, como destacam Germano (2005) e Cunha (2005), a política educacional da ditadura. Em 1980, é realizado o II Seminário Brasileiro de Educação, sob a coordenação da Anped, Cedes e Ande, entidades da sociedade civil, do campo da educação que, a partir de então, transformaram o Seminário em Conferência Brasileira de Educação (CBE). 
Entre os anos de 1980 e 1988, período que nos interessa destacar, considerando que nele foram construídas as principais teses do Movimento Nacional pela Reformulação dos Cursos de Formação do Educador, foram realizadas cinco conferências. A I Conferência Brasileira de Educação ocorreu em abril de 1980, na Pontifícia Universidade Católica (PUC) de São Paulo, com a temática central "A política Educacional". Estruturada em 11 simpósios e 34 painéis, contou com aproximadamente 1.400 participantes. A II CBE foi realizada em Belo Horizonte, na Universidade Federal de Minas Gerais (UFMG), no mês de junho de 1982, com a temática central "Educação: perspectiva na democratização da sociedade". Estruturada em 13 simpósios e 67 painéis, contou com um número aproximado de 2.000 participantes. A III CBE aconteceu em Niterói, na Universidade Federal Fluminense (UFF), no mês de outubro de 1984, com o tema central "Da crítica às propostas de ação". Organizada em 12 seminários e 124 painéis, contou com aproximadamente 5.000 participantes. A IV CBE foi organizada em Goiânia, na Universidade Federal de Goiás (UFG) e Universidade Católica de Goiás (UCG), em outubro de 1986, com o tema central “A educação e a constituinte”. Com um programa estruturado em 25 simpósios, 77 atividades de atualização, 93 painéis e 23 outras atividades, contou com aproximadamente 6.000 participantes. A V CBE foi realizada em Brasília, na Universidade de Brasília (UnB), em agosto de 1988, com a temática central "A Lei de Diretrizes e Bases da Educação Nacional”. Com um programa prevendo 24 simpósios, 250 painéis e atividades de atualização, contou com aproximadamente 6.000 participantes (CUNHA, 2005, p. 94).

No I Seminário de Educação Brasileira, realizado em 1978, além das discussões gerais em torno da temática de redemocratização do país, discutiram-se, conforme afirmam Brzezinski (1996a) e Bissolli da Silva (2003), os estudos pedagógicos em nível superior, concentrando-se em torno dos seguintes temas: extinção ou não do Curso de Pedagogia; formação do pedagogo em geral ou do pedagogo especialista; formação do especialista no professor ou do especialista e do professor no educador; formação do especialista nas habilitações da graduação ou na pós-graduação; formação na perspectiva da pedagogia do consenso, ou da pedagogia do conflito; formação mais teórica ou mais prática; entendimento do pedagogo como reprodutor ou produtor de conhecimentos; adoção de um núcleo central 
ou de uma base comum de estudos, dentre outros (BRZEZINSKI, 1996a). Notadamente, na centralidade das discussões estiveram as temáticas relacionadas aos problemas então vivenciados pelo Curso de Pedagogia. Sob a influência da informação de que o Ministério da Educação (MEC) retomara a matéria das Indicações 67/1975 e 70/1976 do $\mathrm{CFE}^{2}$, os educadores se mobilizaram no esforço de acompanhar e quiçá tentar paralisar tais ações no sentido de impedir a extinção do curso, causa em que o Movimento logrou êxito, uma vez que as Indicações foram sustadas pelo MEC no ano seguinte.

A organização mais sistemática do Movimento para a reformulação dos cursos se deu, porém, na I Conferência Brasileira de Educação, onde os participantes desencadearam uma mobilização nacional, visando a intervir nos rumos do processo de definição das políticas para a formação dos profissionais da educação. Neste evento, realizado em 2 de abril de 1980, no contexto do Governo de João Batista Figueiredo, quando estava à frente do Ministério da Educação e Cultura Eduardo Mattos Portella, foi criado o Comitê Pró-Participação na Formação do Educador, “face à necessidade de mobilização de professores e alunos em torno da reformulação do Curso de Pedagogia, então colocado em debate nacional" (ASSOCIAÇÃO..., 1992). Embora a centralidade das discussões estivesse no Curso de Pedagogia ${ }^{3}$, já naquele momento o Comitê apontava a importância de se ampliar o debate em direção a todas as licenciaturas (ENCONTRO..., 1986).

A atuação do Comitê, a partir de então, esteve vinculada tanto à administração dos conflitos gerados pela diversidade de proposições internas ao Movimento quanto a acompanhar os trabalhos que a Secretaria de Educação Superior (SESu), do MEC, passou a organizar. Dentre as iniciativas do MEC nesse período, destaca-se a realização de sete Seminários Regionais de Reformulação dos Cursos de Recursos Humanos para a Educação, aos quais o Comitê enviou representantes com a intenção de evitar a imposição de mudanças vindas de gabinete e reivindicar a realização de um encontro nacional (BISSOLLI DA SILVA, 2003; BRZEZINSKI, 1996a).

Nessas Indicações o conselheiro Valnir Chagas propunha a extinção do Curso de Pedagogia na forma curricular determinada pela legislação de 1969.

3 Em 1980, os Cursos de Pedagogia alcançaram um total de 206 (BRZEZINSKI, 1996b). 
O I Encontro Nacional ocorreu em 21 de novembro de 1983, com uma programação inicialmente definida pelo MEC. No dia 22, no entanto, em resposta indignada ao fato do Ministério apresentar, já na seção de abertura, uma proposta de formação de professores previamente elaborada, docentes e discentes se fizeram ouvir encaminhando nova pauta aos trabalhos e passando a coordenar o evento. Este ato representou a independência do Movimento, fortalecida, também, pela transformação do Comitê Pró-Formação do Educador em Comissão Nacional de Reformulação dos Cursos de Formação do Educador (CONARCFE). Segundo a Associação... (1992, p. 4), “a Comissão herdou do Comitê o espírito de autonomia frente aos órgãos oficiais, bem como seu objetivo de promover a articulação, em nível nacional, dos esforços destinados a reformular os cursos de formação do educador, sistematizando propostas e experiências".

Criada num contexto de tensão entre educadores e representantes do poder educacional instituído - MEC e SESu, sua ação compreendia duas atribuições principais: primeiro, dar continuidade ao processo de discussão sobre a reformulação dos cursos de formação do educador e, segundo, acompanhar as ações do MEC junto aos cursos de licenciatura (BRZEZINSKI, 1996a; SCHEIBE; AGUIAR, 1999). Embora conturbado, inicia-se, pelo acompanhamento que a Comissão passa a realizar junto às ações do MEC, um processo de maior participação da sociedade civil nas discussões e decisões relativas às políticas educacionais no âmbito da sociedade política.

O firme posicionamento dos participantes neste I Encontro Nacional possibilitou, de um lado, o fortalecimento do Movimento Nacional pela Reformulação dos Cursos de Formação dos Educadores diante das imposições do poder instituído, que passou a reconhecê-lo, embora não de imediato, como legítimo. A princípio, houve resistência do MEC/SESu tanto na aceitação da legitimidade da Comissão Nacional como instância de articulação das diversas propostas relativas à reformulação dos cursos de formação de educadores quanto em considerar os resultados dos estudos e debates do Encontro de Belo Horizonte como expressão do pensamento e das tendências então em discussão no País. De outro lado, promoveu um afastamento ainda maior em relação ao projeto da sociedade política, o que dificultou, em certa medida, o trabalho da Comissão que se seguiu ao 
Encontro Nacional de 1983, em virtude de não contarem mais com o financiamento do Estado (BRZEZINSKI, 1992; 1996a), razão pela qual os encontros posteriores de avaliação foram organizados aproveitando os espaços de outros eventos. Observou-se, então, como estratégia utilizada pelo MEC, enquanto aparelho de Estado, o incentivo às discussões de amplos setores de profissionais da educação, mas o refluxo deste processo quando as decisões, frutos de tais debates, contrariavam o projeto governamental, ou seja, "estímulo ao debate não como uma política de democratização do ensino, mas como uma tática de cooptação dos movimentos sociais" (ENCONTRO..., 1986, p. 153).

Malgradas as dificuldades financeiras impostas à manutenção do Movimento, após o afastamento das propostas do MEC/SESu, a CONARCFE trabalhou intensamente entre 1983 e 1990, promovendo três encontros nacionais de avaliação e quatro encontros nacionais que representavam a continuidade do histórico Encontro de Belo Horizonte. A história deste Movimento, portanto, pode ser subdividida em três períodos, a saber: (i) o primeiro, sob a forma de Comitê Pró-Formação do Educador, entre 1980 e 1983; (ii) o segundo, como Comissão Nacional de Reformulação dos Cursos de Formação do Educador, entre 1983 a 1990 e (iii) o terceiro e atual período como Associação Nacional pela Formação dos Profissionais da Educação (Anfope), a partir de 1990 (ASSOCIAÇÃO..., 1992, p. 5).

\section{A BASE COMUM NACIONAL}

Há quase três décadas, a construção coletiva das proposições da Anfope apóia-se em princípios que expressam o caráter de resistência e contraposição às ações impositivas oriundas das políticas governamentais no campo da formação de professores. Buscou-se, nessa direção, um princípio norteador que expressasse a prática comum na formação de professores contra a imposição dos currículos mínimos. Nos sucessivos Encontros Nacionais aprofundaram-se e ampliaram-se as discussões sobre essa temática, na tentativa de superar as antigas fragmentações presentes no processo de formação e expressas principalmente pela divisão do curso de Pedagogia em Habilitações. Nesse sentido afirmava: 
[...] Haverá uma única base comum nacional para todos os cursos de formação do educador. Esta base comum será aplicada em cada instituição de forma a respeitar as especificidades das várias instâncias formadoras (Escola Normal, Licenciatura em Pedagogia, demais Licenciaturas específicas) (ASSOCIAÇÃO..., 1992, p. 14).

A acepção de base comum nacional esteve marcada por dois sentidos complementares: (i) um sentido político, caracterizando-a como instrumento de luta pela formação e carreira do educador e (ii) e um sentido teórico, constituindo-a como princípio orientador dos currículos dos cursos de formação dos educadores.

No sentido político, a idéia de base comum nacional foi tomada com o objetivo de servir como "instrumento de luta e resistência contra a degradação da profissão do magistério, permitindo a organização e reivindicação de políticas de profissionalização que garantam a igualdade de condições de formação" (ASSOCIAÇÃO..., 2000, p. 9) e a valorização social do educador. Foi considerado, ainda, um elemento unificador da profissão.

No sentido teórico, ainda como princípio orientador dos currículos dos cursos de formação de educadores, opunha-se ao modelo representado pelo "padrão federal” (1939) e, mais tarde, pelo "currículo mínimo" (1969). Inserido no contexto dos anos de 1980, o Movimento foi marcado pela contestação e refutação dos atos advindos da tecnoburocracia, propondo organizar os cursos pelo princípio da base comum nacional como "sustentação epistemológica norteadora da elaboração e do desenvolvimento do currículo" (ASSOCIAÇÃO..., 1994, p. 11). Buscavase, então, pela mediação de uma base teórica comum e de uma consciência política, o desenvolvimento de cursos de formação voltados a uma prática de caráter crítico.

Consensuou-se, assim, ao longo das discussões, que a base comum nacional "teria como função servir de 'ponto de referência para a articulação curricular de cada instituição formadora do profissional da educação' [...] e a sua concretização dar-se-ia por eixos articuladores" (ENCONTRO..., 1990). Importa ressaltar, no entanto, que em torno dos eixos curriculares articular-se-ia um corpo de conhecimentos selecionado em função da concepção sócio-histórica de formação, abrangendo três dimensões fundamentais e intrinsecamente relacionadas, a saber: i) dimensão 
profissional - envolvendo um corpo de conhecimentos capaz de identificar toda a categoria profissional e, ao mesmo tempo corresponder à especificidade de cada profissão; ii) dimensão política - organizada a partir de um corpo de conhecimentos de modo a permitir uma visão globalizante das relações educação-sociedade e do papel do educador comprometido com a superação das desigualdades existentes; iii) dimensão epistemológica - envolvendo um corpo de conhecimentos onde o científico deve ter um espaço privilegiado, rompendo com o senso comum (ENCONTRO..., 1990, ASSOCIAÇÃO..., 1994; 1996; 1998; 2000; 2004).

A garantia de uma prática comum nacional de todos os educadores, qualquer que seja o conteúdo específico de sua atuação, é o objetivo central do princípio, promovendo a compreensão da totalidade do trabalho docente. Esta prática comum estaria centrada, também, na defesa da docência como a base da formação de todos os profissionais da educação, pois permite, segundo a Anfope (2000, p. 9), "assumir com radicalidade, ainda hoje, nas condições postas para a formação de professores, a formulação de Saviani (1982): formar o professor e o especialista no educador”.

Neste sentido, enquanto a legislação regulatória do Curso de Pedagogia de 1969 (BRASIL, 1969) formava os especialistas ou os professores para a docência no ensino de 2o grau, com um curso organizado a partir de habilitações, a proposição da Anfope considerava tanto a formação para a docência quanto para as especialidades de forma integrada. O Curso de Pedagogia deveria, assim, formar o profissional de educação para atuar no ensino, na organização e gestão de sistemas, unidades e projetos educacionais e na produção e difusão do conhecimento, em diversas áreas da educação, sendo, ao mesmo tempo, um bacharelado e uma licenciatura (ASSOCIAÇÃO..., 2000; 2004).

Nessa direção, o profissional a ser formado seria o pedagogo "unitário", que é ao mesmo tempo um bacharel e um licenciado, apto a exercer tanto as funções de magistério na Educação Infantil, nos anos iniciais do Ensino Fundamental e nas matérias pedagógicas do Nível Médio quanto as funções de gestão nas instituições de ensino e a produção e difusão do conhecimento na área da educação.

O Curso de Pedagogia seria organizado por eixos norteadores - sólida formação teórica e interdisciplinar; unidade entre teoria e prática, gestão democrática da escola; compromisso social e ético; trabalho coletivo e interdisciplinar; articulação da formação inicial e continuada - em torno 
dos quais se estabeleceria um corpo de conhecimento compreendendo as dimensões profissional, política e epistemológica, em um processo formativo vinculado à concepção sócio-histórica visando à formação crítica de educador. Um curso de graduação plena, pautado na acepção de docência como base, superando em sua estrutura a separação entre bacharelado e licenciatura, com duração mínima de quatro anos, compreendendo uma carga horária de 3.200 horas $^{4}$, visando à garantia de formação teórica de qualidade.

Infere-se, a partir da leitura dos documentos, que a idéia de uma base comum nacional representava a vontade política de construção de uma concepção elaborada, orgânica e coerente de formação que, articulando o coletivo de educadores, tornar-se-ia hegemônica.

\section{A DOCÊNCIA COMO BASE: O POMO DA DISCÓRDIA}

Conforme vimos, o princípio da base comum nacional compreende a idéia da docência como base da formação do educador. Há entre os educadores, no entanto, conforme registrado nos documentos finais dos Encontros Nacionais, posicionamentos diferenciados a respeito do Curso de Pedagogia que polemizam essa questão (ENCONTRO..., 1984a, 1986, 1989; ASSOCIAÇÃO..., 1992). Segundo Brzezinski (1996a), a polêmica surgiu em função da análise da prática dos especialistas, conduzindo os educadores e se dividirem em dois grupos com posicionamentos antagônicos (ENCONTRO..., 1989). Considerando sua importância no âmbito da construção de uma proposta coletiva representativa do Movimento no enfrentamento do projeto de formação de professores da sociedade política, destacamos esses dois posicionamentos representativos dos dissensos internos presentes nas discussões realizadas nas últimas duas décadas.

O primeiro grupo, composto por intelectuais com participação ativa no Movimento, alguns, inclusive, assumindo a função de presidência da entidade, tem como representantes principais, dada a fecunda produção teórica dedicada ao tema, Aguiar (1999), Aguiar; Mello (2005), Brzezinski (1992; 1996a; 1996b), Freitas (1999; 2001; 2002; 2004) e Scheibe (1999; $2001 ; 2002 ; 2003 ; 2006)$. Neste grupo postula-se a extinção das

\footnotetext{
$4 \quad$ No IX Encontro Nacional a carga horária fora definida em 2.500, sendo ampliada posteriormente para 3.200.
} 
habilitações nos moldes da organização preconizada ao Curso de Pedagogia pela legislação de 1969, compreendendo-a, então, com base em eixos articuladores, numa dinâmica de formação integrada, onde o curso seria, ao mesmo tempo, um bacharelado e uma licenciatura. Estes intelectuais defendem a pedagogia lato sensu, abrangendo o amplo campo da educação, onde sua identidade estaria relacionada à responsabilidade social e, portanto, com o exercício profissional situado historicamente (ENCONTRO..., 1989).

A defesa desta proposta encontra em Freitas (2002, p. 140) o argumento da "necessidade de um profissional de caráter amplo, com pleno domínio e compreensão da realidade de seu tempo, com desenvolvimento da consciência crítica que lhe permita interferir e transformar as condições da escola, da educação e da sociedade”. Destacando o caráter sócio-histórico dessa formação, defende uma concepção emancipadora de educação, avançando no sentido de buscar superar as dicotomias entre professores e especialistas, pedagogia e licenciaturas, especialistas e generalistas. Esta superação, segundo Freitas (2002, p. 140), seria alcançada a partir da formação de um "profissional da educação que tem na docência e no trabalho pedagógico a sua particularidade e especificidade”. Ainda para Freitas (2002), a oposição e a resistência dos educadores à concepção fragmentada de formação - professores e especialistas - fundam-se na necessidade de superação da docência na forma de habilitação, entendendoa como fundante, isto é, base da formação do especialista, na compreensão do trabalho pedagógico escolar como totalidade

O questionamento de Scheibe (2002) ajuda-nos a compreender melhor as defesas desse primeiro grupo de intelectuais: como formar um supervisor, ou como exercer o papel de supervisor escolar sem ter também uma base de formação semelhante a dos docentes? O entendimento concentra-se na questão da docência como trabalho fundamental na escola e, nessa direção, todo educador que desenvolve atividades nela, professor ou não, deve ter na base de sua formação a docência. Ou seja, para supervisionar, orientar, inspecionar em uma instituição dedicada ao ensino seria necessário compreender o trabalho fundamental ali desenvolvido, a docência. A pedagogia, assim, teria como objeto de estudo prioritário a educação formal em ambiente escolar, pois é a partir do profundo conhecimento da educação em ambiente formal que se poderá compreender melhor a educação em ambientes não formais, coerente com o princípio de que o conhecimento 
deve iniciar a partir do mais desenvolvido (ENCONTRO..., 1989; ASSOCIAÇÃO...,, 2006).

Os lineamentos básicos dessa proposta, considerada hegemônica no âmbito do Movimento e no enfrentamento das propostas governamentais, podem ser encontrados nas idéias defendidas por Saviani em 1981. Em seu texto intitulado "Uma estratégia para a reformulação dos Cursos de Pedagogia e licenciatura: formar o especialista e o professor no educador", Saviani defendeu a formação do pedagogo em geral, do "educador generalista", argumentando:

o essencial é formar o educador, o qual, se bem formado, será capaz de exercer as atividades específicas que a maior ou menor divisão de tarefas, segundo a maior ou menor complexidade da organização educacional venha a exigir (SAVIANI, 1981, p. 2).

Ao expressar seu posicionamento contrário às habilitações, o autor concluía que ao invés de "especialistas” em determinada habilitação restrita, estamos necessitando é de

educadores com uma sólida fundamentação teórica desenvolvida a partir e em função das exigências da ação educativa nas condições brasileiras. Este será o profissional com habilitação polivalente capaz de enfrentar os desafios da nossa realidade educacional (SAVIANI, 1981, p. 4).

Dessa acepção de educador polivalente, assentada sob uma base docente, emerge o entendimento de um processo de formação unificado onde todos os egressos estariam qualificados, igualmente, para as funções técnicas especializadas, para as funções do magistério na Educação Infantil, nos anos iniciais do Ensino Fundamental e nas matérias pedagógicas do Ensino Médio e, ainda, para a produção e difusão do conhecimento que se materializam no campo prático-institucional (escolar e não escolar). A docência configura-se, então, como elemento catalisador de todo o processo de formação, pois a partir dela se materializaria o trabalho pedagógico compreendido como práxis educativa e unidade teórico-prática. A docência passa a assumir, então, uma dimensão mais alargada, em consonância com a idéia de educador polivalente e na perspectiva de "mediação para outras funções que envolvem o ato educativo" (SCHEIBE, 2001, p. 7). Em artigo coletivo, publicado em 2006, os integrantes do Movimento reconhecem esse sentido ampliado reportando-se, no entanto, ao fato do trabalho 
pedagógico ser desenvolvido em espaços escolares e não-escolares e não a nova configuração dada à docência (AGUIAR e outros, 2006, p. 9).

O segundo grupo, representado inicialmente por Libâneo (1998; 2001; 2002), importante intelectual brasileiro, envolvido com o Movimento desde os primeiros encontros, vai ganhando novos adeptos, dentre eles Pimenta (1999; 2001; 2002; 2004) e Franco (2002), os quais, contrapondo-se à versão anterior, entendem a pedagogia como teoria geral da educação, tendo como objeto a educação em qualquer ambiente social em que ela ocorra. Em outras palavras: o objeto de estudo da pedagogia é o processo educativo historicamente dado, cabendo-lhe avançar na sistematização e aprofundamento de uma teoria da educação abrangente e não reduzi-la a uma teoria da escola, ou seja, postula-se a pedagogia stricto sensu.

Nessa direção, Libâneo (2002, p. 68), propõe uma tríplice tipologia de pedagogos. Os (i) pedagogos lato sensu seriam "todos os profissionais que se ocupam de domínios e problemas da prática educativa em suas várias manifestações e modalidades"; em seguida, viriam os (ii) pedagogos stricto sensu: seriam "especialistas que, sempre com a contribuição das demais ciências da educação, e sem restringir sua atividade profissional ao ensino, dedicam-se a atividades de pesquisa, documentação, formação profissional, educação especial, gestão de sistemas escolares e escolas, coordenação pedagógica, animação sociocultural, formação continuada em empresas, escolas e outras instituições" (LIBÂNEO, 2002, p. 69); o terceiro tipo, também pedagogos stricto sensu, seriam "professores do ensino público e privado que atuam em todos os níveis e modalidades de ensino" (LIBÂNEO, 2002, p. 69). Estes postulados encaminham a uma compreensão de formação bastante diversa daquela defendida pelo primeiro grupo.

Franco (2002, p. 46), ao discutir as diferenças existentes entre ser pedagogo e ser professor, afirma:

ser o profissional que promove, organiza e pesquisa a formação docente será sempre diferente de ser o profissional que se formará para ser o docente, embora não exclua, nem a relevância de ambos os papéis, nem a possibilidade de concomitância desses papéis.

Neste entendimento, o primeiro seria aquele cuja formação e prática voltar-se-iam à pesquisa e à produção e difusão do conhecimento científico em pedagogia. O segundo, o professor, dedicar-se-ia ao ensino. Embora 
remeta à possibilidade de concomitância de papéis, esta tese demarca uma cisão sustentada pela diferenciação tanto das especificidades dos saberes inerentes a cada um quanto da particularidade da ação que desempenham, em consonância com as proposições de Libâneo. Ou seja, um é pesquisador, outro é professor.

Nessa perspectiva de formação, segundo Pimenta (2006), a docência configura-se como uma das modalidades de formação e inserção profissional do pedagogo, onde a pedagogia seria a base da formação e da atuação profissional do professor, e não o contrário como configura a posição da Anfope.

Estes dissensos têm como marca histórica o ano de 1983, porquanto nele foram construídos os princípios gerais do Movimento. O posicionamento mais efetivo, no entanto, ocorreu no IV Encontro Nacional e nos encontros subseqüentes, culminando, por ocasião das discussões sobre as Diretrizes Curriculares Nacionais para o Curso de Pedagogia (DCNP), em um manifesto enviado ao Conselho Nacional de Educação (CNE) intitulado "Manifesto de Educadores Brasileiros sobre as Diretrizes Curriculares Nacionais para os Cursos de Pedagogia" ${ }^{5}$, apoiado, nessa ocasião, por aproximadamente cem educadores que o assinaram. Nesse documento, os signatários defendiam o entendimento de que a formação dos profissionais da educação para atuação na Educação Básica e em outras instâncias de prática educativa far-se-ia nas Faculdades/Centros/Departamentos de Educação, oferecendo curso de bacharelado em Pedagogia e curso de Formação de Professores, argumentando: "o objeto da legislação em questão não pode ser o curso de licenciatura para a formação de professores, mas o de bacharelado em pedagogia, que se destina à formação de profissionais da educação não docentes voltados para os estudos teóricos da pedagogia, para a investigação científica e para o exercício profissional no sistema de ensino, nas escolas e em outras instituições educacionais, incluindo as não-escolares" (MANIFESTO..., 2005).

Em entrevista concedida a Rodrigues (2005, p. 204), por ocasião da feitura de sua tese, na qual discute o Curso de Pedagogia, Libâneo explicita ainda melhor esse entendimento:

Educadores Brasileiros, liderados por José Carlos Libâneo, encaminham ao CNE o"Manifesto de Educadores Brasileiros",opondo-se tanto à proposta do CNE quanto àquela defendida pela ANFOPE e entidades parceiras, na defesa do Curso de Pedagogia como um bacharelado, em 20/09/2005. 
Se a formação de professores deve ser feita integralmente numa Faculdade de Pedagogia, então temos no curso de Pedagogia o bacharelado com habilitações e um Centro de Formação de Professores de Educação Básica, ou seja, as licenciaturas, com percursos curriculares distintos.

E mesma autora afirma: "ai eu teria que trabalhar com a idéia de habilitações, não tem jeito” (2005, p. 202).

Parece-nos, pois, que mais uma vez, os dissensos se estabelecem em função das questões fundamentais que acompanham a história do Curso de Pedagogia: (i) quem é o pedagogo? Na perspectiva da Anfope, um professor, cuja formação para exercer a docência, lhe permite atuar, também, como gestor e pesquisador no campo da educação. Na perspectiva defendida por Libâneo, o pedagogo é o cientista da educação, o pesquisador que poderá, em um outro percurso formativo, preparar-se para ser professor; (ii) Qual a estrutura a ser dada ao Curso de Pedagogia? Segundo a Anfope, um curso único, em que a docência se configura como a base de uma formação integrada para atuação no magistério, na gestão e na produção e difusão do conhecimento. Segundo Libâneo, uma estrutura que contemple cursos diferentes dedicados à formação para o magistério, para a gestão e para a pesquisa, uma organização pautada em habilitações. Na centralidade da primeira proposta está a licenciatura, na segunda, o bacharelado.

Para Helena Costa Lopes de Freitas, os mentores intelectuais da segunda proposta fortalecem tanto o MEC quanto o CNE na implementação das novas concepções do perfil necessário de professores e especialistas na realidade atual da reforma educativa. Com isso, "tentam introduzir novamente no campo da escola, sob o manto do pesquisador e do cientista da educação, as antigas tarefas do 'especialista' supervisor e gestor, agora sobre novas bases, determinadas pelas políticas da reforma educativa [...]" (FREITAS, 2002, p. 7). Para Libâneo (2002, p. 91), no entanto, "padece de suporte conceitual e histórico a idéia corrente entre os educadores brasileiros de denominar pedagogia ao curso de formação de professores para as séries iniciais do Ensino Fundamental, e de pedagogo ao professor formado por esse curso".

Constata-se, pois, que muitas são as críticas a apontar as limitações de um e de outro posicionamento. Caberia, ao primeiro, o ônus de reduzir a pedagogia à docência e, ao mesmo tempo, contraditoriamente, de corroborar com o fenômeno do "alargamento" das funções docentes. Ao 
segundo posicionamento, o ônus de retomar as dicotomias presentes na história do curso, às quais o Movimento buscou superar na sua longa trajetória de enfrentamentos com os legisladores, representantes, na sua grande maioria, dos interesses da sociedade política.

\section{CONSIDERAÇÕES FINAIS}

As propostas elaboradas no âmbito do Movimento, representaram a ruptura com o pensamento tecnicista, evidenciando novas tendências, dentre as quais ganhou destaque, especialmente por sua natureza emancipadora, a concepção sócio-histórica de educação. Tais propostas influenciaram fortemente as concepções que embasaram os trabalhos das duas Comissões de Especialistas do Ensino de Pedagogia que estiveram à frente dos trabalhos de elaboração das DCNP, entre os anos de 1998 e 2002. Por essa influência, os princípios da docência como base e da base comum nacional estiveram representados nos documentos produzidos que, por sua vez, foram encaminhados ao MEC/CNE.

No longo período que antecedeu a aprovação das DCNP, homologadas pela Resolução no ${ }^{1}$, de 15 de maio de 2006, posições antagônicas estiveram em tensionamento demonstrando interesses diversos no campo da educação e, especialmente, da formação de educadores. Nesse embate, o Movimento se manteve em posição de alerta, pronunciando-se em defesa da proposta de formação de educadores que foi construída coletivamente na perspectiva de garantir, na medida do possível, as finalidades políticas e as posições teóricas firmadas desde a década de 1980.

\section{REFERÊNCIAS}

AGUIAR, Márcia Ângela; SCHEIBE, Leda. Formação de profissionais da educação no Brasil: o curso de pedagogia em questão. Educação \& Sociedade, Campinas, v. 20, n. 68, dez. 1999.

AGUiAR, Márcia Ângela; MELlO, Márcia. Pedagogia e diretrizes curriculares: polêmicas e controvérsias. Linhas Críticas, Brasília, n. 11, jan./jun. 2005, p.119-138.

AGUIAR, Márcia Ângela da S. et al. Diretrizes curriculares do curso de pedagogia no Brasil: disputas de projetos no campo da formação do 
profissional da educação. Educação \& Sociedade, Campinas, v. 27, n. 96, out. 2006.

ASSOCIAÇÃO NACIONAL PELA FORMAÇÃO DOS PROFISSIONAIS DA EDUCAÇÃ̃, 1992, Belo Horizonte. Documento Final do Encontro Nacional de 1992. Belo Horizonte: ANFOPE, 2000. Disponível em: $<w w w . l i t e . f a e . u n i c a m p i . b r / a n f o p e>$. Acesso em: jul. 2005.

ASSOCIAÇÃO NACIONAL PELA FORMAÇÃO DOS PROFISSIONAIS DA EDUCAÇÃ̃, 1994, Belo Horizonte. Documento Final do Encontro Nacional de 1994. Belo Horizonte: ANFOPE, 2000. Disponível em: <www.lite.fae.unicampi.br/anfope>. Acesso em: jul. 2005.

ASSOCIAÇÃO NACIONAL PELA FORMAÇÃO DOS PROFISSIONAIS DA EDUCAÇÃO, 1998, Belo Horizonte. Documento Final do Encontro Nacional de 1998. Belo Horizonte: ANFOPE, 2000. Disponível em: <www.lite.fae.unicampi.br/anfope>. Acesso em: jul. 2005.

ASSOCIAÇÃO NACIONAL PELA FORMAÇÃO DOS PROFISSIONAIS DA EDUCAÇÃO, 2000, Belo Horizonte. Documento Final do Encontro Nacional. Belo Horizonte: ANFOPE, 2000. Disponível em: $<$ www.lite.fae.unicampi.br/anfope>. Acesso em: jul. 2005.

ASSOCIAÇÃO NACIONAL PELA FORMAÇÃO DOS PROFISSIONAIS DA EDUCAÇÃO, 2004, Belo Horizonte. Documento Final do Encontro Nacional. Belo Horizonte: ANFOPE, 2000. Disponível em: <www.lite.fae.unicampi.br/anfope>. Acesso em: jul. 2005.

BISSOLLI DA SILVA, Carmem Silvia da. Curso de pedagogia no Brasil: história e identidade. Campinas: Autores Associados, 2003.

BRASIL. Conselho Federal de Educação. Resolução n. 2, de 11 de abril de 1969. Fixa os mínimos de conteúdo e duração a serem observados na organização do Curso de Pedagogia. Documenta, n. 100, 1969.

BRZEZINSKI, Iria. Pedagogia, pedagogos e formação de professores: busca e movimento. Campinas: Papirus, 1996a.

BRZEZINSKI, Iria. Pedagogia e formação de professores: dilemas e perspectivas. ENDIPE, 8., 1996b, Florianópolis. Anais... Florianópolis: NUP/ CED/UFSC, 1996b.

BRZEZINSKI, Iria. Trajetória do movimento para as reformulações curriculares dos cursos de formação de profissionais da educação: do Comitê (1980) à ANFOPE (1992). Em Aberto, Brasília, v. 12, n. 54, p. 75-86, abr./jun.1992.

ENCONTRO NACIONAL DE AVALIAÇÃO DA COMISSÃO NACIONAL DE REFORMULAÇÃO DOS CURSOS DE FORMAÇÃO DE EDUCADORES, 2., 1984. Niterói. Documento Final. Mimeografado.

ENCONTRO NACIONAL DA COMISSÃO NACIONAL DE REFORMULAÇÃO DOS CURSOS DE FORMAÇÃO DO EDUCADOR, 2., 1986. Belo Horizonte. Documento Final. Mimeografado. 
ENCONTRO NACIONAL DA COMISSÃO NACIONAL DE REFORMULAÇÃO DOS CURSOS DE FORMAÇÃO DO EDUCADOR, 4., 1989. Belo Horizonte. Documento Final. Disponível em: <www.lite.fae.unicampi.br/anfopes. Acesso em: julho de 2005.

ENCONTRO NACIONAL DA COMISSÃO NACIONAL DE REFORMULAÇÃO DOS CURSOS DE FORMAÇÃO DO EDUCADOR, 5., 1990. Belo Horizonte Documento Final. Disponível em: <www.lite.fae.unicampi.br/anfope>. Acesso em: julho de 2005.

CUNHA, Luiz Antonio. Educação, Estado e democracia no Brasil. 5. ed. São Paulo: Cortez; Niterói: Editora da Universidade Federal Fluminense; Brasília: FLACSO do Brasil, 2005.

FRANCO, Maria Amélia Santoro. A pedagogia para além dos confrontos. In: FÓRUM DE EDUCAÇÃO - Pedagogo: que profissional é esse. 2002, Belo Horizonte. Anais..., Belo Horizonte: FAE/CBH/UEMG, 2002. p. 3962 .

FREITAS, Helena Costa Lopes de. Construir políticas de formação contra a barbárie neoliberal: as diretrizes para os cursos de formação de professores da educação básica. Disponível em: <www.apropucsp.org.br/revista/ r13_r07.htm>. Acesso em: 10 jan. de 2006.

FREITAS, Helena Costa Lopes de. A reforma do ensino superior no campo da formação dos profissionais da educação básica: as políticas educacionais e o movimento dos educadores. Educação \& Sociedade, Campinas, v. 20, n. 68, dez. 1999. p.17-44.

FREITAS, Helena Costa Lopes de. Construir políticas de formação contra a barbárie neoliberal: as diretrizes para os cursos de formação de professores da educação básica. PUCVIVA, São Paulo, n. 13, jul./set. 2001. Disponível em: <www.apropucsp.org.br/revista/r13_r07.htm>. Acesso em: 10 jan. 2006.

FREITAS, Helena Costa Lopes de. Formação de professores no Brasil: 10 anos de embates entre projetos de formação. Educação \& Sociedade, Campinas, v. 23, n. 80, set. 2002. p.136-167.

FREITAS, Helena Costa Lopes de. Novas políticas de formação: da concepção negada à concepção consentida. In: BARBOSA, Raquel Lazzari Leite (Org.). Trajetórias e perspectivas da formação de educadores. São Paulo: Editora UNESP, 2004. p. 89-116.

GERMANO, José Willington. Estado militar e educação no Brasil. São Paulo: Cortez, 2005.

GRAMSCI, Antonio. Maquiavel, a política e o Estado Moderno. Rio de Janeiro: Editora Civilização Brasileira. 1978.

KUENZER, Acácia Zeneida. A formação dos profissionais da educação: proposta de diretrizes curriculares nacionais. 1998. (Mimeo). 
LIBÂNEO, José Carlos. Ainda as perguntas: o que é a pedagogia, quem é o pedagogo, o que deve ser o curso de Pedagogia. In: Pedagogia e pedagogos: caminhos e perspectivas. São Paulo: Cortez, 2002.

LIBÂNEO, José Carlos. Pedagogia e pedagogos, para quê? São Paulo: Cortez, 1998.

LIBÂNEO, José Carlos. Que destino os educadores darão à pedagogia? In: PIMENTA, Selma Garrido (Coord.). Pedagogia, ciência da educação? São Paulo: Cortez, 2001.

MANIFESTO DE EDUCADORES BRASILEIROS. Sobre as Diretrizes Curriculares Nacionais para os Cursos de Pedagogia. Encaminhado ao CNE em 20 de setembro de 2005. (Mimeo).

PIMENTA, S. G. (Org.) Saberes pedagógicos e atividades docentes. In: PIMENTA, S. G. Formação de professores: identidade e saberes da docência. 2. ed. São Paulo: Cortez, 1999.

PIMENTA, Selma Garrido (Coord.). Pedagogia, ciência da educação? São Paulo: Cortez, 2001.

PIMENTA, Selma Garrido (Org.). Pedagogia e pedagogos: caminhos e perspectivas. São Paulo: Cortez, 2002.

PIMENTA, Selma Garrido. Pedagogia: sobre Diretrizes Curriculares. In: FORUM NACIONAL DE PEDAGOGIA, Belo Horizonte, jul. 2004.

RODRIGUES, Marli de Fátima. Da racionalidade técnica à "nova” epistemologia da prática: a proposta de formação de professores e pedagogos nas políticas oficiais atuais. Curitiba, 2005. 228 f. Tese (Doutorado em Educação) - Universidade Federal do Paraná.

SAVIANI, Dermeval. A nova lei da educação: trajetória, limites e perspectivas. 3. ed. Campinas: Autores associados, 1997.

SCHEIBE, Leda. Pedagogo: perspectivas e desafios frente às novas diretrizes curriculares. In: FÓRUM DE EDUCAÇÃO - Pedagogo: que profissional é esse. 2002, Belo Horizonte. Anais..., Belo Horizonte: FAE/CBH/UEMG, 2002.

SCHEIBE, Leda; AGUIAR, Macia Ângela. Formação de profissionais da educação no Brasil: O curso de pedagogia em questão. Educação \& Sociedade, Campinas, n. 69, p. 220-238. 1999.

SCHEIBE, Leda; AGUIAR, Márcia Ângela. A política de expansão do ensino superior no Brasil: avaliação e credenciamento. 2002. Mimeografado.

SCHEIBE, Leda. O curso de Pedagogia no embate entre concepções de formação. In: GUIMARÃES, Valter Soares. Formar para o mercado ou para a autonomia. Campinas: Papirus, 2006.

SCHEIBE, Leda. Pedagogo: perspectivas e desafios frente às novas diretrizes curriculares. In: Anais do Fórum de Educação, Belo Horizonte: FAE/CBH/ UEMG, set. /2002a. 
SCHEIBE, Leda. Políticas de formação dos profissionais da educação neste início de século: análise e perspectivas. In: REUNIÃO ANUAL DA ANPED, 26., 2003, Poços de caldas. Anais..., Poços de Caldas: ANPED, 2003.

SCHEIBE, Leda; BAZZO, Vera Lúcia. A construção de uma base comum nacional para a formação de profissionais da educação no Brasil. Contrapontos, Itajaí, v. 1, p. 91-103, 2001. 


\section{Universidade e formação de professores: qual o peso da formação inicial sobre a construção da identidade profissional docente ?}

Cristina Maria d'Ávila

Ver-se como autor, saber-se responsável, reconhecer-se na profissão. Estas questões passam, inexoravelmente, pelo processo de escolha profissional desde o seu nascedouro. Deslindar as razões que levam um jovem a se interessar pela carreira docente e compreender, no seu interior, o papel que cumpre um curso de formação inicial, particularmente no terreno das disciplinas didático-pedagógicas, constitui-se em nosso objeto de estudo.

Esse recorte se dá no âmago de um panorama educacional problemático: as condições de trabalho, os magros salários, a desvalorização social que concorrem para a desprofissionalização docente no Brasil, em que pesem os movimentos de educadores e estudantes, os fortes debates acadêmicos e as mais recentes publicações sobre a formação de professores e o trabalho docente (VEIGA, 2000; 2002; 2005; LIBÂNEO, 2000; 2006; NÓVOA, 2002, PIMENTA, 2000; TARDIF, 2002; TARDIF; LESSARD, 2005, dentre outros). O que nos salta aos olhos é que mesmo diante de um cenário pouco estimulante de trabalho, tenhamos um número significativo de alunos que abraçaram a licenciatura como primeira escolha. Da sondagem que realizamos, $52 \%$ dos estudantes afirmaram ter escolhido o curso por se sentirem identificados com a profissão, $36 \%$ apontaram outros motivos 
e, dentro destes, $59 \%$ disseram terem escolhido o curso por realização pessoal. Portanto, malgradas as precárias condições de trabalho, o que leva jovens estudantes à opção pela docência? Onde se enraíza o desejo de se tornar docente? Como se constrói essa identidade profissional e qual o papel do curso de formação inicial, particularmente da didática, nesse processo?

O currículo dos cursos de licenciatura reproduz o que historicamente significou a curta fatia destinada à formação de professores. Brevemente podemos dizer que ainda hoje, em cursos de licenciatura que ainda não passaram pela reforma curricular datada de 2001, os estudantes cursam cinco semestres de disciplinas específicas voltadas para sua formação no bacharelado - sem qualquer relação com a docência - e mais três semestres das disciplinas chamadas pedagógicas, dirigidas à formação para a docência. Esse quadro está em reforma.

Com o processo de elaboração das Diretrizes curriculares nacionais (DCN) para a graduação, conduzido pela Secretaria de Ensino Superior do Ministério da Educação (SESu/MEC) no ano de 2001, a Licenciatura ganhou terminalidade e integralidade própria em relação ao Bacharelado, constituindo-se em um projeto específico, rompendo com a antiga formação de professores que ficou caracterizada como modelo “ $3+1$ ”. A proposta incluiu a discussão das competências e áreas de desenvolvimento profissional, sendo assim flexível, para abrigar diferentes desenhos institucionais. Atualmente, a carga-horária de estágio é de 300 horas (Parecer CNE 5/2006), o que consideramos inadequado como período de exercício da prática pedagógica. Como bem afirmou Nóvoa (2002, p. 22)

\footnotetext{
os professores nunca viram seu conhecimento específico devidamente reconhecido. Mesmo quando se insiste na importância da sua missão, a tendência é sempre considerar que lhes basta dominar bem a matéria que ensinam e possuírem um certo jeito para comunicar e para lidar com os alunos. O resto é dispensável.
}

A problemática mencionada e tomada ao apreço pelo autor, sem dúvida, conduzem ao desprestígio da profissão: «'semi-ignorantes', os professores são considerados as pedras-chave da nova 'sociedade do conhecimento'» (NÓVOA, 2002, p. 22). Reduz-se assim a nobre profissão ensinante a um estatuto de profissão sem importância. 
A discussão em torno da dicotomia teoria-prática nos cursos de licenciatura continua. No âmbito desses cursos, é freqüente colocar-se o foco quase que exclusivamente nos conteúdos específicos das áreas, em detrimento de um trabalho sobre os conteúdos que serão desenvolvidos no ensino fundamental e médio. A relação entre o que o estudante aprende na licenciatura e o currículo que ensinará no segundo segmento do ensino fundamental e no ensino médio continua abissal. Concorre para isso também uma visão simplificadora da prática. E como bem assinalamos anteriormente, o desprestígio que acomete o conhecimento didático pedagógico nas universidades. Tal visão parece bem arraigada no meio acadêmico que compartilha de uma cultura universitária - um conjunto de significados, representações e comportamentos - um tanto desqualificadora do próprio meio profissional. Segundo Libâneo, em prefácio à obra de Guimarães (2004, p. 13), são traços dessa cultura, a prevalência dos discursos teóricos, a hipervalorização da pesquisa em detrimento do ensino, desvalorização das práticas profissionais e da licenciatura, individualismo exacerbado. Infelizmente são traços que nutrem também o imaginário do estudante de licenciatura que passa «naturalmente» a rejeitar a docência ou a menosprezar a formação.

Assim, com base nos resultados da sondagem que realizamos como primeira etapa da pesquisa e, nos apoiando em estudos anteriores (Cf. DUBAR, 1991; CATTONAR, 2005; GERVAIS, 2005; LENOIR; MAUBANT, 2007), podemos afirmar que o curso de licenciatura tem tido um peso limitado sobre a construção da identidade profissional docente. Com efeito, $36 \%$ dos sujeitos da pesquisa afirmaram que a origem do desejo de ser professor repousa sobre o exemplo de algum professor no passado, na escola de nível fundamental ou médio; sobre a mesma questão, apenas $16 \%$ declararam que os estudos, na formação inicial em nível universitário, estão na origem da sua identidade profissional.

Em suma, temos um quadro que caracteriza a formação inicial como problemático, diante do qual concebemos como principais hipóteses: a) o peso relativo da formação inicial no processo de construção da identidade profissional dos futuros professores; b) as disciplinas do curso de licenciatura não parecem aos estudantes corresponder às representações do ato de ensinar. Diante do exposto nos indagamos: Como se constrói a identidade profissional docente? Que condições, no curso de formação inicial, podem 
favorecer a construção dessa identidade? Qual o papel das disciplinas de formação pedagógica, especificamente, da Didática geral e didáticas específicas, nesse processo?

\section{Metodologia}

Trata-se de um estudo exploratório e, como tal, não procura demonstrar uma hipótese inicial, mas principalmente descobrir caminhos inexplorados e desvelar pistas ricas em questões a serem aprofundadas. Este trabalho combina uma abordagem quantitativa (peso relativo das respostas ao questionário) preliminar e uma segunda abordagem, principal, sobre a qual nos concentraremos, na análise sobretudo qualitativa dos resultados que trazem como referência uma análise das representacões presentes, nas escritas autobiográficas dos estudantes, sujeitos do estudo. Sublinhamos que a sondagem inicial por questionário teve por objetivo, principalmente, o enriquecimento da problemática e contextualização da pesquisa, não incidindo, pois, de modo direto, sobre a análise dos resultados finais.

Tivemos como população, na primeira etapa - sondagem via questionário - 78 estudantes cuja faixa-etária variou entre 18 e 45 anos, situando-se a maioria, 54\%, na faixa etária entre 18 e 24 anos, de 26 a 30 anos, $18 \%$; de 31 a 35 anos, $6 \%$; de 36 a 40 anos, $8 \%$; de 41 a 45 anos, 8 $\%$, de 45 anos acima, $6 \%$. Desses estudantes, $53 \%$ são do sexo masculino e 47 feminino; $69 \%$ trabalham e, desses, $55 \%$ como docentes. Esses estudantes se encontravam no $5^{\circ}$ semestre do curso de licenciatura, sob um total de oito semestres. A sondagem foi realizada entre 2005-2006 em 12 cursos: Licenciatura em Educação Física, Filosofia, Desenho e Plástica, Biologia, Geografia, Música, Economia, Ciências sociais, Dança, Matemática, Química e Estatística, numa universidade pública na Bahia. $\mathrm{Na}$ segunda etapa, trabalhamos com as escritas autobiográficas de metade desses 78 estudantes.

Para a análise dos dados da parte aberta do questionário, recorremos à verificação de conteúdo a partir de codificação de categorias abertas (uma categorização não pré-determinada, mas construída no processo de estudo das respostas). Erigimos como categorias: "representações da profissão docente"; "representações do ato de ensinar"; "representações do ser 
professor". Recorremos também a tratamento estatístico para o conjunto das respostas, abertas e fechadas.

Para análise dos escritos autobiográficos, recorremos à análise de conteúdo, apoiados sobre a teoria das representações sociais, a partir de um paradigma interpretativista. A escrita autobiográfica foi escolhida como metodologia qualitativa por apresentar várias vantagens, dentre as quais podemos destacar: a retomada das histórias vividas continuamente, perscrutar com maior acuidade as representações dos sujeitos, suas crenças e influências sobre a escolha profissional. No processo de análise dos escritos autobiográficos, concebemos duas categorias que sustentaram a interpretação dos dados: são elas, os "modelos" e "contramodelos de ensino" Compreendemos esses "modelos de ensino" como um tipo de identificação com normas, valores, crenças e modelos comportamentais dos membros dos "grupos de referência" dos estudantes de licenciatura, isto é, de seus professores. Os "contramodelos" se referem a modelos comportamentais negativos de ensino, vividos e marcantes em suas trajetórias (CATTONAR, 2005; DUBAR, 1991).

\section{IDENTIDADE PROFISSIONAL DOCENTE: UMA IDENTIDADE SOCIAL E PESSOAL}

Identificar-se com uma profissão, desenvolver uma intimidade com a mesma, de modo a não poder imaginar-se fazendo outra coisa. Estar impregnado deste fazer, integrado a este universo, sendo assim reconhecido pelo que se faz. É encarnando as relações sociais que o indivíduo configura uma identidade pessoal, uma história própria, um projeto de vida (PIMENTA, 2004). Embora o conceito seja polissêmico, numa coisa diversos autores concordam: a identidade se constrói. Ninguém nasce com uma identidade pessoal definida, a mesma se constitui ao longo da existência humana, na relação com os outros e com o meio sociocultural. Da mesma forma, a identidade profissional. Não há um marco zero neste processo. Sua construção, garante Pimenta (2004) depende de espaços de formação ou de emprego para se estruturar, sendo, assim, condicionada socialmente.

Adotaremos, neste trabalho, o conceito de identidade profissional a partir de um quadro conceptual provindo sobretudo da sociologia, 
sustentando que a identidade profissional é um processo ao mesmo tempo social e pessoal (DUBAR, 1991; JOSSO, 1991; TARDIF; LESSARD, 1999; BRZEZINSKI, 2002; NÓVOA, 2002; CATTONAR, 2005). É pessoal porque singular, intransferível, própria a cada indivíduo com sua trajetória original, construindo-se no diálogo do sujeito consigo mesmo, e com seu entorno. É também social, pois construída coletivamente e nas relações do sujeito com outrem. Neste sentido, é contextual, constrói-se de modo situado num tempo/espaço histórico determinado.

\section{UMA IDENTIDADE SOCIALMENTE CONDICIONADA}

De acordo com Pereira e Martins (2002), a identidade profissional docente deve ser entendida como prática social construída pela ação de influências e grupos que configuram a existência humana. A prática educativa é uma prática social; assim sendo, a constituição da identidade docente só acontece no âmago dessa prática, e em relação com outros, com o grupo de pertença. Assim, compreender esse processo passa pela compreensão do seu próprio caráter intersubjetivo e relacional.

Segundo Dubar (1991) há dois processos convergentes ou não que concorrem para a constituição das identidades: um processo biográfico (identité pour soi) e um processo relacional, sistêmico e comunicacional (identité pour autrui). O primeiro está ligado à trajetória de cada um, o que inclui múltiplas esferas, seja da família, da formação escolar e profissional, do trabalho, etc.; o segundo, relacional, está ligado às relações partilhadas em atividades coletivas, organizações, instituições etc. Neste sentido, não há como se pensar numa disjunção possível entre identidade individual e identidade coletiva.

No caso da identidade profissional docente, o sujeito do trabalho é o ser humano, portanto sua característica mais marcante é a interrelação entre as partes (aquele que ensina e aquele que aprende). Nesse sentido, é um trabalho interativo, por definição. Um trabalho que conduz à interação no seio de uma organização. Como tal, os professores constroem e reconstroem uma identidade profissional pertinente a um grupo, ou ainda, a subgrupos específicos, a depender do segmento ao qual pertençam (educação infantil, ensino fundamental, ensino médio) e de suas características específicas. Existe 
uma dinâmica identitária significativa nesse contexto (LESSARD; TARDIF, 2003). A identidade também se constitui de forma relacional ou seja, referese à relação do sujeito consigo mesmo e também com o outro. É a um só tempo uma relação de identidade e de alteridade, construída através de um processo contínuo de identificação e de diferenciação imbricado na experiência com o próximo. Nesse particular é muito importante o papel conferido ao ambiente de trabalho e a relação entre os professores e seu meio. É na relação com os pares que a identidade profissional ganha forma: observando, refletindo, discutindo para se compreender os afazeres do métier e assumir, assim, um certo perfil singular de ser professor, uma identidade, porém construída na relação e no contexto do trabalho.

A identidade profissional resulta, portanto, de uma socialização própria ao grupo de pertença profissional. Significa dizer que as experiências comuns são importantes, assim como o próprio processo de formação inicial. Tal socialização, portanto, significa, para os professores em formação, um processo de identificação ligada a tipos identitários específicos, disponíveis e definidos como ideais (DUBAR, 1991).

\section{UMA IDENTIDADE AO MESMO TEMPO PESSOAL}

A identidade é também uma construção pessoal, singular e complexa, o que não nega todas as suas implicações sociais. Ela é ao mesmo tempo estável e provisória, individual e coletiva, subjetiva e objetiva; multirreferencializada, pois resultante de múltiplas interfaces; contextualizada e situada pois enraízada em espaços/tempos determinados e determinantes. O processo de construção identitária é um processo biográfico contínuo "e a identidade pode ser vista como o resultado de uma transação entre uma identidade herdada do passado e uma identidade visada pelo indivíduo ou imposta pela situação presente" (CATTONAR, 2005, p. 197).

Portanto não se pode reduzir as identidades sociais às determinações do campo profissional e da formação porque, segundo Dubar (1991, p. 119), desde a infância o indivíduo herda uma identidade de gênero, uma identidade étnica e uma identidade de classe social - identidades essas ligadas à família. Entretanto, é na escola que a criança vive a experiência de sua primeira identidade social. 
A construção da identidade profissional tem estreita relação com a profissionalidade, entendendo este conceito como conjunto de conhecimentos, capacidades, habilidades, ie., competências gerais, para além da disciplina que ensina. Corresponde a um modo de ser, as qualidades que identificam os elementos necessários à profissão. A profissionalidade está articulada à formação inicial, à experiência que resulta da prática e à formaçao continuada. Ao identificar-se com a profissão, o sujeito passa a desenvolver um perfil, um modo de ser, ganha, por assim dizer, uma nova estatura diante da qual se posta como profissional. Desenvolve a sua profissionalidade.

\section{Profissionalidade E PROFISSIONALIZAÇão}

É muito sutil a diferença entre esses dois conceitos. Em busca de uma síntese possível, sustentamos que a profissionalidade se refere às competências (habilidades, atitudes e saberes) desenvolvidas ao longo do processo de profissionalização do docente (LIBÂNEO, 2000; VEIGA e outros, 2005; BREZEZINSKI, 2002; LESSARD; TARDIF, 2003). Neste caso, o sujeito/ ator/professor pode desenvolver suas competências desde o processo de formação inicial ou, e principalmente, no exercício da sua profissão, ao adentrar no espaço escolar e praticar suas atividades pedagógicas. A profissionalização se refere ao processo onde se insere a profissionalidade essa busca incessante por uma identidade ou perfil profissional.

O conceito de profissão - do latim professio: declaração, profissão,exercício, emprego - evolui socialmente e está marcado por mudanças sociais e econômicas ocorridas ao longo da história. Não é por isso uma palavra neutra, diferenciando-se do que se entende no senso comum por ofício ou ocupação. A profissão é um ato específico e complexo e diz respeito a um grupo especializado, competente. Nesse sentido, um grupo profissional é formado por pessoas que se mantêm unidas por uma identidade e por uma ética comuns (VEIGA e outros, 2005, p. 25).

Segundo Dubar (1991) o termo profissão possui dois sentidos correntes: um que diz respeito à ocupação e outro que se refere à profissão, ela mesma. A profissão designa a um só tempo um conjunto de empregos reconhecidos na linguagem administrativa e as profissões liberais (profissões médicas e juristas, notadamente) Neste sentido, uma profissão é uma ocupação na 
qual os práticos dispõem de um monopólio sobre as atividades que ela implica e de um lugar na divisão social do trabalho. Pode-se ainda falar de uma distinção jurídica entre profissão e ocupação: os membros de uma profissão podem se organizar em associações profissionais; os que se incluem numa ocupação, podem se organizar em organismos sindicais. Ainda segundo Dubar (1991, p. 150): "mesmo se uma minoria de assalariados fazem reconhecer sua atividade como uma 'profissão', a maioria não consegue, ou, só parcialmente" (falamos então de “semi-profissões”). Será esse o caso da profissão docente?

Ao lado da formação especializada, a profissão requer autonomia e colegialidade. A autonomia se refere à capacidade de tomar decisões e a colegialidade à união coesa e entre os membros de um grupo regulados por um código comum. "Assim, o conhecimento especializado, a formação em nível superior, a autonomia, o prestígio social, o controle de qualidade e um código de ética são características que servem para definir uma profissão" (DUBAR, 2005, p. 26).

A profissionalidade, por seu turno, se refere a um conjunto de capacidades e saberes desenvolvidos no desempenho de suas funções num determinado momento histórico (BRZEZINSKI, 2002, p. 10) Saberes estes que evoluem e se ressignificam no exercício da profissão. Essas transformações ocorridas na vida dos professores é que levam à profissionalização. A profissionalidade de um grupo de trabalhadores diz respeito, portanto, a tais competências: capacidades, racionalização de saberes estruturados e mobilizados no exercício profissional; o seu aperfeiçoamento contínuo constitui o desenvolvimento profissional. A característica da profissionalidade é a sua instabilidade, vez que se constrói progressivamente em contextos específicos. É enquadrada por um sistema de referências ou código de ética, garantindo, assim, a finalidade social da atividade profissional (LESSARD; TARDIF, 2003).

Do ponto de vista da análise do trabalho, é um constructo social, afirmam Lessard e Tardif (2003, p. 19), para onde confluem múltiplas demandas, saberes e características: é, pois, um constructo demandado por instâncias políticas e administrativas; é objeto de co-construção entre formadores e organização escolar, formalizada num referencial de competências, sendo pois produto do trabalho dos formadores e seus formados; a profissionalidade está também estreitamente relacionada à construção identitária dos professores (2003, p. 19). 
A profissionalização se refere ao processo de aquisição das capacidades específicas da profissão. Não se resume à formação profissional, embora a inclua, mas envolve outras características de cunho também subjetivos, como aptidões, atitudes, valores, formas de trabalho que se vão constituindo no exercício da profissão. "É, portanto, um projeto sociológico voltado para a dignidade e para o status social da profissão, em que se incluem também as condições de trabalho, a remuneração e a consideração social de seus membros" (VEIGA, 2005, p. 31).

Para o que nos toca de perto, a profissionalidade e a profissionalização representam os saberes e o processo pelos quais passam os profissionais no desenvolvimento de uma identidade ao mesmo tempo pessoal e social com a profissão.

\section{ETAPAS DO DESENVOLVIMENTO PROFISSIONAL}

A capacidade de refletirmos sobre os desafios apresentados no nosso dia-a-dia e, particularmente, no dia-a-dia da profissão nos obriga à revisão constante de conceitos. Assim, a identidade profissional está calcada em superações de problemas de vida. Essas transformações paradigmáticas, levam, por assim dizer, a mudanças de necessidades e aspirações dos indivíduos. Portanto as identidades nunca se encontram prontas, estão em constante construção, o que se exprime pelo seu caráter processual e autoreflexivo. Em suma, advogamos, aqui, que a identidade é um processo construtivo e em permanente transformação.

Para falarmos deste processo, antes de mais nada, desejamos situar o leitor no terreno em que o mesmo adquire raiz. Para compreendermos esse contexto, tenhamos em mente, o ciclo de vida da profissão docente a partir das seguintes etapas que sintetizamos a partir da literatura consultada: Socialização preprofissional; Socialização profissional : formação inicial; Inserção no meio profissional (entrada); Estabilidade profissional (DUBAR, 1991; CATTONAR, 2005; RIOPEL 2006). 


\section{SOCIALIZAÇÃO PRÉ-PROFISSIONAL}

O que significa a socialização pré-profissional? Esta é uma socialização, antes de tudo, subjetiva, complexa e informal. O que significa dizer que diz respeito à trajetória de cada um, portanto ela se desenvolve de forma particular em cada sujeito. A identidade profissional docente se encontra ancorada em experiências ancestrais, em grande parte, na experiência de vida de cada um como estudante em nível primário e/ou secundário. Esse período portanto, vivido pelas pessoas, pode lhes fazer eclodir as primeiras identificações com a profissão. É nesse momento portanto, que se iniciam as primeiras identificações e que o sujeito pode vir a elaborar seus modelos ideais de ensino e de como vir a ser professor. É um tipo de identificação antecipada para o grupo dos professores, porque enquanto estudantes vão adquirir normas, valores, crenças e modelos comportamentais dos membros do seu "grupo de referência", ou seja de seus professores. Muitas vezes essas normas são reproduzidas em jogos infantis, e mais tarde postas em prática no meio profissional, de modo inconsciente (CATTONAR, 2005). Desta forma, a socialização profissional parece acontecer antes da entrada no ofício. Mesmo os docentes que escolheram a profissão como segunda opção, contam histórias que remontam à infância e, nestas, o despertar do gosto pelo ensino.

Os estudantes em formação, assim como professores já na ativa, vão nos contar sempre histórias em que os modelos de professores vêm à tona como sujeitos que marcaram suas vidas. E o interessante é que as qualidades que os primeiros atribuem aos seus professores marcantes são aquelas que eles próprios pretendem ou reproduzem no exercício da profissão, denotando assim um certo sentimento de filiação. Existe ainda aqueles que são considerados contra-modelos, ou aqueles professores dos quais não se guarda boas memórias e que não se pretende reproduzir. São exemplos fortes de como "não fazer" ou de como "não ser". Enfim, são modelos diversos que marcam porque não correspondem aos ideais da profissão concebidos pelos estudantes.

As histórias de cada um, portanto, se constituem em material nuclear se quisermos refletir sobre o processo identitário em qualquer profissão; por esta razão e para melhor compreendermos o processo de construção da identidade profissional docente, recorremos à análise de escritos autobiográficos dos estudantes. Os relatos autobiográficos, segundo Catani e outros (1997, p. 
40), ajudam a compreender como os sujeitos reconfiguram suas identidades. A reconfiguração do passado com os olhos do presente, sem dúvida, possibilita uma compreensão mais larga da experiência e uma inserção mais clara na profissão.

\section{SOCIALIZAÇÃO PROFISSIONAL}

O curso de formação inicial inaugura o momento da profissionalização na docência. É uma fase instituída e também instituinte de uma identidade profissional que se estrutura a partir de saberes teóricos e práticos da profissão; de modelos didáticos de ensino e de uma primeira visão sobre o meio profissional docente. É um momento importante na construção da identidade docente, já que os sujeitos se transformam nas interrelações que ali se estabelecem. Considerada como uma fase de socialização mais formal, é na formação inicial que o futuro docente vai se deparar com os chamados conhecimentos teóricos ou saberes curriculares acadêmicos (TARDIF, 2002) e também com modelos ideais de profissionalidade, advindos muitas vezes das teorias educacionais.

Segundo Pimenta e Lucena (2004, p. 64), os cursos de formação de professores são fundamentais no fortalecimento da identidade "à medida em que possibilitam a reflexão e a análise crítica das diversas representações sociais historicamente construídas e praticadas na profissão". Então, é no confronto entre o "eu profissional" e "o outro" que se estabelecem as diferenças e as possibilidades de análise crítica referente às posturas assumidas nas práticas educativas. É na relação com o outro que o processo de individuação se consolida - no "não querer fazer assim", ou, na melhor das hipóteses, na admiração do exercício profissional de quem já se encontra na profissão (o olhar sobre as práticas de professores regentes de disciplinas, seja num passado remoto, seja na própria formação universitária). É sem dúvida um processo sofrido de decepções, muito esforço pessoal, solidariedade, abandono, solidão e compartilhamento que o exercício docente abre brechas para a constituição da identidade profissional. Muito embora os estudantes de licenciatura possuam críticas quanto a esse processo de formação, não há como negar que este incida, positiva ou negativamente, sobre a construção da identidade nos futuros professores. 
As críticas dos estudantes ao curso de formação universitária se apoiam sobre duas questões fundamentais: primeira, sobre a falta de apoio material da instituição (55\%); e, segundo, sobre a prática de ensino (25\%), os demais teceram críticas à falta de apoio institucional e ao currículo defasado. De fato e ainda hoje nos deparamos com problemas de infra-estrutura, na universidade, como os citados pelos alunos. Somado a isso os exemplos nas práticas docentes parecem não se constituir como referentes ideais. São muitos os debates em torno da questão, e, grande parte destes situam o problema na falta de nexo entre a formação teórica e prática no período de socialização profissional inicial. Com efeito, perguntados sobre os problemas na prática de ensino universitária, $40 \%$ se queixam da falta de aulas práticas, $20 \%$ afirmam que seus professores são mais pesquisadores do que professores, $20 \%$ dizem que os professores têm problemas com a avaliação e outros $20 \%$ são “impacientes”. É voz corrente a opinião que, primeiro, os estudos iniciais preparam mal e, segundo, que os exercícios práticos são mais importantes que os "conhecimentos teóricos" (DUBAR, 1991).

Dos momentos mais importantes no processo de construção identitária profissional, encontram-se a saída do sistema escolar e a entrada e confrontação no mercado de trabalho. A entrada numa especialização disciplinar constitui-se assim em ato significativo para a identidade do profissional, mas é na confrontação com o mercado de trabalho que se localiza o aspecto identitário mais importante; é lá, nessa primeira confrontação que se vai consituir uma identidade profissional de base, uma projeção de si para o futuro, enfim, a colocação em prática de uma certa lógica de aprendizagem e também de formação. A entrada na profissão domina um modelo prático concernente às tarefas cotidianas, ao trabalho duro que tem pouco a ver com o modelo idealizado caracterizado pela dignidade da profissão e sua valorização simbólica provinda da formação inicial (DUBAR,1991, p. 146).

Decorre desse processo, as projeções pessoais pela profissão a partir de uma identificação com os membros que pertencem a um "grupo de referência", o que inclui a imagem de si, apreciação de suas próprias capacidades, realizações de desejos, choques, frustrações, projeções para o futuro profissional etc. No caso da formação inicial para a docência são os mestres/professores, essa referência. Uma referência antecipada que pode 
nascer desde a mais tenra idade em modelos de professores da infância. Convém assinalar, que tal processo não se encerra aí - será regularmente confrontado com as transformações tecnológicas, organizacionais e políticas, implicando sempre em projeções para o futuro. Assim, essa primeira identidade profissional está marcada pela incerteza e parafraseando Dubar (1991) podemos mesmo compará-la à passagem da adolescência para a vida adulta e, portanto, a uma forma de estabilização social.

AlgunS RESUlTAdOS: O PAPEL DA FORMAÇÃO INICIAL NO PROCESSO DE CONSTRUÇÃO IDENTITÁRIA

As hipóteses que sustentamos na introdução (1- o peso limitado da formação inicial sobre a construção da identidade profissional e 2- as disciplinas dirigidas à formação pedagógica não correspondem às representações de docência dos estudantes) ganham corpo quando observamos os dados colhidos e nos permitem concluir, sobre a $1^{a}$ hipótese, apoiando-nos também sobre outros estudos, (RIOPEL, 2006; CATTONAR, 2005) que são frágeis os laços que unem formação inicial de professores e a construção identitária (no que concerne ao contexto deste estudo).

Quanto à segunda hipótese, em curso de investigação, podemos depreender, a partir das narrativas dos estudantes e das respostas ao questionário, que suas representações de docência não correspondem aos referentes concretos da formação inicial. Quando perguntados sobre o que é ser professor, por exemplo, 29\% responderam "Gostar do que faz/ensinar com competência e satisfação"; $21 \%$ "Ser agente de transformação social”; $21 \%$ "Atuar visando o crescimento individual"; $18 \%$ "Ser educador, amigo, companheiro"; $11 \%$ "Ser mediador do processo ensino-aprendizagem". Nos seus escritos autobiográficos, as queixas quanto aos professores que tiveram na universidade estão intimamente relacionadas ao autoritarismo, à negligência e ao distanciamento afetivo dos estudantes. Perguntados sobre o que é ensinar, $35 \%$ responderam que significa "Ajudar a pensar/ desenvolver o espírito crítico"; $25 \%$ "Criar condições para a construção/ reconstrução do conhecimento"; 17\% "Trocar experiências”; 17\% "Mediar saberes, valores e experiências"; 6\% "Transmitir informações". Representações essas que não se coadunam com as críticas que fazem aos estudos na formação inicial. 
São visões idealizadas nascidas de suas trajetórias de vida, mas já ilustram que parecem distantes das disciplinas cursadas na faculdade, por exemplo. Nos relatos autobiográficos, quando solicitados sobre histórias marcantes na construção de suas identidades como futuros professores, foram muito restritivos quanto à influência dos estudos universitários, apenas três modelos positivos e cinco contramodelos, num total de 39 escritos.

Os dados das narrativas autobiográficas quando confrontados com os dados colhidos dos questionários aplicados parecem confirmar a hipótese de que as experiências vividas sobretudo no ensino fundamental são mais fortes na memória dos estudantes e mesmo na constituição de sua identidade profissional, que as experiências vividas no ensino superior. Efetivamente dos 39 estudantes, $50 \%$ da população que fez parte da enquete por questionário, que descreveram suas memórias escolares e fatos marcantes na construção de suas identidades profissionais, 26 são referentes ao curso de nível fundamental, três ao ensino médio, dois à educação infantil e oito ao nível universitário.

O que podemos retirar como lição dessas narrativas? primeira, a de que se encontra em modelos do passado, principalmente no ensino primário (de $1^{a}$ à $4^{a}$ séries) o principal referente de identificação com a profissão; segundo, de que os contramodelos de professores e de docência são mais fortes ou reverberam mais nas suas memórias que os modelos positivos. Efetivamente, dos 39 memoriais escritos, 28 se referem às experiências negativas ou contramodelos de ensino, ou seja praticamente $72 \%$ do total contra $28 \%$ que se referiram a modelos positivos de docência.

Os modelos fortes do passado estão localizados, a partir da escrita dos estudantes, sobretudo no nível primário, vejamos alguns extratos:

[...] Será que essas aulas sempre iguais onde o professor é a autoridade máxima e se impõe sem se importar em consultar nossas opiniões e necessidades se fixam na nossa lembrança de forma a nunca se perder ? Com certeza não são essas as recordações que quero perpetuar quando for atuar em sala de aula, mas sim os passeios pelo desconhecido, as minhas descobertas pessoais, meus olhos espantados por ver saltar dos livros didáticos coisas que eu não lembraria se não as tivesse vivenciado. Aliás, essa é a palavra mágica que guardo da parte boa da escola: vivência (E1).

Tudo isso faz parte do meu processo educativo e vou guardar isso sempre. Cada dia que conheço mais a educação percebo como foi importante passar por essas fases... (E2). 
Descrever parece simples, mas para mim marcou toda a minha vida escolar e eu fui evoluindo à medida que me debatia com novos desafios e obstáculos... (E3).

Os contramodelos têm muita força também na constituição de um perfil profissional. E no ensino fundamental, é capaz de deixar marcas indeléveis (dos 39 escritos, 28 se referem a experiências negativas de ensino). Dentre os contramodelos flagrados e registrados pelos nossos alunos em seus escritos autobiográficos, podemos elencar como atitude mais marcante, o autoritarismo revelado sob diferentes ângulos, dentre os quais destacam-se os métodos conservadores da pedagogia tradicional; a desqualificação (ou violência moral); e a punição (violência física). São, em síntese e não sem dor, as lições apreendidas pelos estudantes (extratos de seus escritos a seguir):

Eu me recordo que a professora na ocasião ainda não havia completado a licenciatura e provavelmente não tinha cursado a disciplina de didática (ou ao menos não parece tê-la usado quando deveria), posto que mostrou incompetência na direção da sala de aula. [...] Não se pode crucificá-la por tal ato impensado, mesmo porque isso não era recorrente, todavia é importante apontá-lo como uma falha no exercício da docência e uma experiência ímpar que me permite hoje afirmar que me policiarei para não fazer o mesmo quando lecionar, pois senti as consequências que tais atos podem provocar no aluno (E4).

O ponto crucial dessa história reside no fato de que havia outras formas de lidar com a situação, mas a professora, tradicionalíssima, preferiu não "destruir" sua postura dominadora [...] escolhendo escorraçar de sua sala, durante um bom tempo, um aluno que sempre gostou de estar ali (E5).

Certamente essas experiências não devem ter contado, no momento da escolha da profissão, mas reverberaram em suas vidas e ainda irão se repercutir em suas práticas profissionais e, na melhor das hipóteses, surgirão como negação do que foi vivido ou como uma outra forma de desenvolverse na profissão.

Dos modelos positivos na universidade (três num total de 39 relatos ou menos de $10 \%$ do total), os estudantes enalteceram as qualidades: lúdica, sensível (relacional), comprometida e competente de engajamento dos professores na prática profissional:

Eu ia tranquilo para as aulas, feliz com minha professora, animado com a idéia dela ter me enxergado e se preocupado com meu aprendizado no meio de tantos outros alunos. Ela particularizou o olhar dela, individualizou o ensino, desceu do salto, iniciou um processo de construção do meu saber e conversou 
comigo como se fôssemos iguais. Como se fôssemos... [...] Pedagogias à parte, a relação professor-aluno é uma relação de poder assimétrica, mas não pode ser marcada por uma distância abissal. Diminuir a assimetria é objetivo das mais variadas abordagens, independente do conteúdo e da instituição. Estamos lutando contra séculos de tradição (ainda em vigor) e sinais de mudança aparecem tímida e esporadicamente. A professora não tinha um discurso democrático,... e talvez nem conhecesse as abordagens pedagógicas a fundo, mas ela estava se tornando menos tradicional do que podia perceber. Tudo bem, ela não foi intencionalmente construtivista, mas a experiência serviu para a reconstrução de um novo esquema em mim. Não sobre a teoria, mas sobre o professor (E6).

Foi proposta como uma das formas de avaliação seminários em grupo. [...] Observei que nesses momentos a professora apresentava uma atitude muito atenta: circulava pelos grupos, esclarecia dúvidas e observava... [...] Apesar das primeiras avaliações seguirem os moldes tradicionais ... a última abria espaço para a pesquisa em grupo e o desenvolvimento da expressão oral. [...] Acredito que a professora teve uma postura muito sensível as minhas necessidades naquele momento... (E7).

Dos contramodelos de docência em nível superior revelados nas narrativas dos alunos (cinco num total de 39 relatos), temos como marcas preponderantes, o autoritarismo, a displicência e a indiferença:

Durante meu curso de história na universidade tive alguns professores que atuaram apenas como palestrante, simples fornecedores de informações. Eram displicentes e indiferentes aos alunos em suas diversas necessidades. Irresponsáveis na execução de sua função, negligenciavam o papel de educador na formação de novos educadores. Foi para mim marcante o Doutor (como ele mesmo gostava de lembrar) em história. Trago-o como exemplo de uma catástrofe na sala de aula a partir de um fato acontecido que demonstra perfeitamente a sua falta de preparo e sua postura tradicionalista-ditatorial (EI).

Foi em época de final de semestre em um seminário e minha equipe estava conversando com a tal professora. Ela adotou um método em que todas as pessoas da sala tinham que julgar as equipes, dando seu ponto de vista de como a equipe apresentada se saíra, mas eu não concordava de jeito nenhum, pelo fato de que na minha opinião, uma pessoa no 'mesmo barco' que você te julgando seria antiético, o mesmo que um atrista plástico falar para outro que sua obra é uma porcaria, ou seja, colegas, futuros educadores, falarem para a equipe que sua apresentação foi o máximo ou até mesmo um lixo (na maioria!). [...] Ela não concordou comigo, tentou de todas as formas mudar minha opinião e disse ironicasarcasticamente: Coitadinha, tão nova e já é do sistema... [...] Moral da história: tenha opinião própria, não se intimidando por achar o que você acha ir contra o que seu professor acha (E9). 
As idéias herdadas e provindas do seu meio e sua história pessoal refletem um retrato idealizado da organização escolar e da profissão docente. Constituem-se assim em referência, importante situada no coração da motivação para tornar-se docente (TARDIF; LESSARD, 1999). Formam, por assim dizer, um quadro de referência de identidade profissional idealizada pelo futuro docente. Esssas visões, trazidas pelo estudante podem tanto facilitar a aprendizagem do meio profissional - quando estes compreendem os saberes da ação, o reconhecimento de situações típicas, etc. - como podem também não estar bem ajustadas à realidade onde se encontram os estudantes, tornando-se assim um obstáculo à aprendizagem (RIOPEL, 2006). É no seio da formação inicial, sobretudo no ensino das didáticas, geral e específicas, que se encontra o momento adequado para se identificar essas representações, compreendê-las e, também, transformá-las.

\section{À GUISA DE CONCLUSÃO}

Parece-nos que o elo entre a construção da identidade profissional (que deveria ser um dos objetivos da formação profissional), e formação inicial parece perdido. E por quê? São frequentes os reclamos em torno das práticas de ensino superior e da falta de vivências no terreno escolar como condição para o desenvolvimento de competências requeridas pela profissão. E no que toca mais de perto ao presente estudo, parece que estamos ainda distantes de um trabalho de escuta das representações desses estudantes, dos seus saberes e quereres nas disciplinas do curso de licenciatura. Um trabalho capaz de fazer brotar os desejos de ensinar e de tornar-se educador.

Pesquisas recentes têm demonstrado o problema do desenvolvimento ou da falta de identidade profissional nos jovens professores (RIOPEL, 2006), e isso, evidentemente, nos remete ao lugar que ocupa essa problemática em cursos de formação de professores. Essa é uma etapa que traz em si momentos distintos: o choque diante da nova realidade, a iniciação e a descoberta (TARDIF; LESSARD, 1999; HUBERMAN, 1999). E o que pode facilitar a transição entre um e outro momento é justamente estar identificado com a profissão.

É preciso, pois, que repensemos os programas de formação em termos de seus objetivos, conteúdos e formatos de aplicação didático-pedagógicas. 
Perrenoud (2001) apresenta duas razões que sustentam a idéia de se preparar os futuros professores para a realidade que lhes aguarda: 1- atenuar o choque com a realidade, diminuir reações agressivas e/ou depressivas que podem estar presentes logo na entrada do metier. 2- Justificar a construção de instrumentos e de saberes que permitam afrontar o real. Não basta antecipar se não se oferece instrumentos adequados. Afirma o autor (2001, p. 9):

Se os docentes conhecessem mais profundamente as raízes da violência, os fundamentos da autoridade, os determinantes da relação com o saber, a fragilidade do sentido da escola, a importância das interrelações, eles se sentiriam menos impotentes.

Neste caso, há que se encontrar o equilíbrio: num curso de formação inicial não se pode passar nem uma visão quixotesca de tudo poder enfrentar, diante de uma realidade por vezes adversa, nem seu inverso ou a visão fracassada de nada poder. Os cursos de formação de professores devem se basear sobre as dificuldades dos alunos, permitindo a estes o desenvolvimento de competências de alto nível: como a capacidade de problematizar e de encontrar as próprias respostas. Nesse sentido, será preciso pensar em cursos de formação onde a binomia teoria-prática não se oponha e nem se distancie.

A formação inicial será tanto mais importante para a carreira do futuro professor quanto mais próximo ele estiver da construção identitária desse sujeito. E isso passa pela sua organização coletiva. Para além da academia, esses cursos têm que estar em relação muito estreita com o meio escolar de atuação desses futuros ensinantes. O que significa dizer que será preciso um curso com matérias mais sensíveis às verdadeiras necessidades desse sujeito. Antes de tudo que seja um curso aberto a escutar, entender, saber de suas crenças, convicções e representações sobre o que é ensinar e aprender, o que é ser professor, etc. Um curso assentado sobre o que pensam os sujeitos e que lhes favoreça um olhar para mais além, para o desenvolvimento de competências emergidas no próprio contexto escolar; sobre seus "saberes" e seus "quereres".

No processo de construção da identidade e profissionalidade docentes é inegável a importância de uma Didática geral - sem que se destitua do terreno as didáticas específicas com suas singularidades epistemológicas e 
pedagógico-didáticas - erigida enquanto conhecimento de iniciação e de mediação. Longe de se constituir em disciplina prescritiva, a didática tem um papel na iniciação desses sujeitos no seu processo de construção identitária e, como conhecimento de mediação, tem o papel de tradução das representações, desejos e crenças dos futuros professores em outras e novas competências profissionais. Nessa abordagem o trabalho formativo voltado à construção da identidade profissional é objetivo precípuo.

\section{REFERÊNCIAS}

BRASIL. Lei n. 9394, de 20 de dezembro de 1996. Estabelece as diretrizes e bases da educação nacional. Brasília: Ministério da Educação, 1996.

BRASIL. Proposta de Diretrizes para a Formação inicial de Professores da Educação Básica, em cursos de nível superior. Brasília: Ministério da Educação, 2000.

BRASIL. Diretrizes Curriculares Nacionais para a Formação de Professores da Educação Básica, em nível superior, curso de licenciatura, de graduação plena. Brasília: Ministério da Educação, Conselho Nacional de Educação, 2001.

BRZEZINSKI, Iria (Org.). Profissão professor: identidade e profissionalização docente. Brasília: Plano Editora, 2002, 196 p.

CANDAU, V. M. (Org.) et al. A didática em questão. 4. ed. Petrópolis: Vozes, 1985.

CANDAU, Vera (Org) et al. Didática, currículo e saberes docentes. Rio de Janeiro: DPeA Editora, 2002.

CATANI, Denice et al. Docência, memória e gênero. São Paulo: Escrituras editora, 1997.

CATTONAR, Branka. L'identité professionnelle des enseignants $d u$ secondaire. Dissertation doctorale. Université Catholique de Louvain, Belgique, 2005.

CATTONAR, Branka. Convergence et diversité de l'identité professionnelle des enseignantes e des enseignants du secondaire en communauté française de Belgique: tensions entre le vrai travail et le sale boulot. In: Éducation et francophonie. Revue scientifique virtuelle ACELF, v. 34, n.1, Printemps 2006, p.193-212.

DAMIS, Olga T. Formação pedagógica do profissional da educação no Brasil: uma perspectiva de análise. In: VEIGA, Ilma Passos Alencastro; AMARAL, Ana Lucia (Org.). Formação de professores: políticas e debates. São Paulo: Papirus, 2002, p. 97-130. 
D’ÁVILA, Cristina M. Decifra-me ou te devoro: o que pode o professor frente ao manual escolar, 2001, 408f, Tese (Doutorado em Educação) FACED/UFBA, Salvador.

D’ÁVILA, Cristina M. (Org.) Anais do II Coloquio Formação de Educadores: ressignificar a profissão docente. Salvador, PPGEDUC/UNEB, 2006.

DUBAR, Claude. La socialisation. Construction des identités sociales et professionnelles. Paris : Armand Colin, 1991.

ENGUITA, Mariano Fernandez. A ambigüidade da docência: entre o profissionalismo e a proletarização. Revista Teoria da educação, n. 4, Porto Alegre, p. 41-61, 1991.

GERALDI, C.; FIORENTINI, D.; PEREIRA, E. (Org.). Cartografias do trabalho docente: professor(a)-pesquisador(a). 2. ed. São Paulo: Mercado de Letras, ALB, 2001.

JOSSO, Christine. Cheminer vers soi. Suisse: Éditions l'Age d'home, 1991. . Experiências de vida e formação. Lisboa: EDUCA, 2002.

LESSARD, C.; TARDIF, M. Les identités enseignantes. Analyse de facteurs de différenciation du corps enseignant québécois 1960 - 1990. Sherbrooke : Éditions du CRP, Université de Sherbrooke, 2003.

LIBÂNEO, José Carlos. Que destino os educadores darão à pedagogia? In: PIMENTA, Selma (Org.). Pedagogia, ciência da educação? São Paulo: Cortez Editora, 1996

LIBÂNEO, José Carlos. Educação, pedagogia e Didática - o campo investigativo da pedagogia e da Didática no Brasil: esboço histórico e buscas de identidade epistemológica e profissional. In: PIMENTA, Selma (Org.). Didática e formação de professores: percursos e perspectivas no Brasil e em Portugal. 3. ed. São Paulo: Cortez Editora, 2000.

LIBÂNEO, José Carlos. Didática e didáticas específicas: questões de pedagogia e epistemologia. COLOQUIO FORMAÇÃO DE EDUCADORES: ressignificar a profissão docente, 2., 2006, Salvador, Anais... Salvador: PPGEDUC/UNEB, 2006. p.1-15.

NÓVOA, António. Formação de professores e trabalho pedagógico. Lisboa: Educa, 2002.

PIMENTA, Selma. Panorama atual da Didática no quadro das ciências da educação: educação, pedagogia e Didática. In: PIMENTA, Selma (Org.). Pedagogia, ciência da educação? São Paulo: Cortez Editora, 1996. 
PIMENTA, Selma (Org.). et al. Didática e formação de professores: percursos e perspectivas no Brasil e em Portugal. 3. ed. São Paulo: Cortez Editora, 2000.

- Para uma ressignificação da Didática - ciências da educação, pedagogia e didática. In: PIMENTA, Selma (Org.). Didática e formação de professores: percursos e perspectivas no Brasil e em Portugal. 3.ed. São Paulo: Cortez Editora, 2000.

PIMENTA, S.; LUCENA. Estágio e docência. São Paulo: Cortez, 2004. $196 \mathrm{p}$.

RIOPEL, Marie Claude. Apprendre à enseigner: une identité professionnelle à développer. Laval: Les presses de l'Université Laval, 2006. 206 p.

SCHEIBE, Leda. Formação dos profissionais da educação pós-LDB: vicissitudes e perspectivas. In: VEIGA, Ilma Passos Alencastro; AMARAL, Ana Lucia (Org.). Formação de professores: políticas e debates. São Paulo: Papirus, 2002, p. 47-61.

SCHÖN, Donald A. (1992). Formar professores como profissionais reflexivos. In Nóvoa, A. (Org.). Os professores e sua formação. Lisboa: Dom Quixote, 1992.

TARDIF, Maurice. Saberes docentes e formação profissional. 2. ed. Petrópolis: Vozes, 2002.

TARDIF, Maurice; LESSARD, Claude. Le travail enseignant au quotidien. Contribution à l'étude du travail dans les métiers et les professions d'interactions humaines. Laval (Canadá): Les presses de l'université Laval, 1999.

TARDIF, Maurice; LESSARD, Claude. Trabalho docente. Petrópolis: Vozes, 2005.

VEIGA, Ilma Passos Alencastro (Org.). Repensando a Didática. São Paulo: Papirus, 1994.

VEIGA, Ilma Passos Alencastro (Org.). Didática: o ensino e suas relações. São Paulo: Papirus, 1996.

VEIGA, Ilma Passos Alencastro; CASTANHO (Org.). Pedagogia universitária: a aula em foco. São Paulo: Papirus, 2000.

VEIGA, Ilma Passos Alencastro; AMARAL, Ana Lucia (Org.). Formação de professores: políticas e debates. São Paulo: Papirus, 2002. 


\section{Políticas públicas e educação de jovens e adultos}

Maria Olivia de Matos Oliveira

GLOBALIZAÇÃo, SOCIEDAdE INFOMÁTICA E EDUCAÇÃO DE JOVENS E ADULTOS

A passagem da sociedade industrial para a sociedade informática provocou profundas alterações no plano econômico, político, cultural e ideológico da sociedade atual.

O período atual é um período de crises: econômica, social, política e moral. Um período que se caracteriza pelo medo generalizado; abandono da solidariedade e desamparo do cidadão.Um período onde o medo da fome, da violência, do desemprego e até do outro estão presentes (SANTOS, 2001, p. 58).

Os grupos que detêm a hegemonia da tecnologia impõem um poder simbólico e cultural, reconceitualizando valores universais como democracia, direito à propriedade e á educação, impondo um “senso comum", determinando normas de conduta, formas de ação e indicando o que é certo ou errado para o mundo.

Novas relações entre países e novas condições materiais de vida são produzidas como explica com muita propriedade Santos (2001, p. 65)

Essa globalização tem que ser encarada a partir de dois processos paralelos. De um lado dá-se a produção da materialidade, ou seja, das condições materiais que nos cercam e que são a base da produção econômica, dos transportes e das comunicações. De outro há a produção de novas relações sociais entre países, classes e pessoas. A nova situação vai se alicerçar em duas colunas centrais. Uma tem como base o dinheiro, outra se funda na informação [...]. 
Nesse contexto, a tirania do dinheiro e da informação ${ }^{1}$ pilares da globalização, produzem um Estado fraco, mínimo, que permite a expansão e a reificação do mercado, que pode ser sintetizado no Brasil, por um modelo de privatização, cuja característica prinipal é financiar as empresas estrangeiras que compram o capital social nacional. O referido modelo é caracterizado por um assistencialismo estatal transferido ao terceiro setor, representado pelas empresas (SANTOS, 2001, p. 66).

A flexibilidade do Estado fortalece as políticas de privatização que trazem no seu rastro, a exclusão social e a condenação de milhões de pessoas à marginalização e ao desemprego. O tempo é de exclusão, que assegura privilégios a poucas pessoas e exacerba a competitividade e o individualismo. A perversidade sistêmica institucional caracteriza o processo de globalização ${ }^{2}$, onde ser pobre é uma situação estrutural e natural ao processo (SANTOS, 2001).

Nessa mesma linha de pensamento Boneti (2006) cita que, até os intelectuais na academia reconhecem que, por trás do estabelecimento de parâmetros nas pesquisas feitas no Brasil sobre o conceito de condição social, existe todo um processo de dominação econômica e cultural que diferencia os segmentos.

São palavras do referido autor:

A valorização real e simbólica do capital social apropriado determina a construção de um parâmetro de sujeito ideal ou de segmento social ideal. A partir deste parâmetro é que se consolida a idéia da igualdade ou da desigualdade [...] (BONETI, 2006, p. 41).

Dessa maneira, são construídos distintos parâmetros de pobreza : os oficiais, orientados por uma lógica burocrática racionalista e, aqueles utilizados pelas classes pobres, que definem pobreza como a falta de acesso aos bens sociais como trabalho, emprego, escola, etc. Em outras palavras, estabelece-se uma valorização diferenciada dos bens sociais e culturais habilidades, hábitos culturais, bens patrimoniais, etc. - a partir dos segmentos sociais que os possuem (BONETI, 2006, p. 41).

Santos (2001), discorre com muita propriedade sobre os dois pilares da globalização: a ideologia do dinheiro que tem como medida geral: acumulação para uns ou endividamento para outros e a tirania da informação que através da mídia dissimula o engodo em nome do marketing, a mentira como segredo de marca, tomando lugar do debate civilizatório que não se faz presente.

2 Santos (2001, p. 33) se refere á perversidade produzida pela globalização,onde o encolhimento das funções sociais e políticas do estado ajudam a ampliar cada vez mais a pobreza. 
Nesse sentido, segundo Boneti, a instância burocrática do Estado determina a construção da condição social por meio daquilo que Castells chama de "identidade legitimadora, introduzida pelas instituições dominantes da sociedade, no intuito de expandir e racionalizar sua dominação em relação aos atores sociais [...]" (CASTELLS, 1999 apud BONETI, 2006, p. 32). Acrescenta ainda o referido autor : "Essa construção social da noção da desigualdade faz dos iguais os desiguais" (BONETI, 2006, p. 33). Dessa forma, o diferente e desigual é o pobre; legitima-se assim a condição de ser pobre e não de estar pobre.

Os jovens e adultos analfabetos fazem parte desse segmento pobre e marginalizado. A educação de jovens e adultos hoje no Brasil, enfrenta de um lado, o desafio de responder às necessidades materiais de milhares de pessoas analfabetas que vivem em extrema pobreza, e do outro, a responsabilidade de atender às atuais exigências de um mundo globalizado.

OS DESAFIOS E RESPONSABILIDADES SOCIAIS DA EDUCAÇÃO

DE JOVENS E ADULTOS

Por outro lado Castells (1997) mostra que as demandas por uma escolarização básica não são apenas conseqüência da escolaridade deficiente da nossa população, mas da constante evolução de sociedade informática que provoca uma mudança nas necessidades educativas dos jovens e adultos, diferentes das exigências de antigamente.

Sabe-se quão importante é renovar os conhecimentos, pois aqueles que adquirimos na educação inicial não servem para todas as formas de inserção na sociedade e no mundo do trabalho. Vive-se um processo social de troca e produção de conhecimentos, cujo principal produto são as idéias e onde não há espaço para os analfabetos (LÈVY, 1993).

Acresce a tudo isso, na atual sociedade da informação a constatação de que a cultura dominante continua priorizando os saberes acadêmicos, em detrimento dos demais saberes. Na Educação de Jovens e Adultos (EJA), os sujeitos têm um conhecimento ou saber vivido que difere do conhecimento ou saber escolar: no primeiro aflora o valor da experiência, do saber popular, o valor da maturidade e da sabedoria.

Os jovens e adultos em situação de exclusão social e com níveis iniciais de estudos desenvolvem igualmente habilidades comunicativas que lhes 
permitem atuar tanto na sua vida cotidiana como no mundo laboral, de forma plena, desde que a escola, tome como ponto de partida a valorização dessas habilidades, legitimando os conhecimentos que eles possuem e que fazem uso no seu cotidiano, chamadas de habilidades comunicativas básicas (FLECHA, 2001) ${ }^{3}$.

Isso significa que, do ponto de vista metodológico, a EJA deve além de trabalhar os conteúdos sistematizados, aproveitar as experiências dos discentes, numa perspectiva de análise crítica, para provocar uma discussão permanente entre os alfabetizandos e sobre o que estão aprendendo. É importante o respeito pelos saberes vividos, pelas experiências e pelas motivações internas que integram a auto-estima desse segmento populacional. As instituições deveriam desenvolver uma prática pedagógica que provocasse o debate permanente sobre as relações existentes entre o saber escolar e o saber vivido, trabalhando tanto os conteúdos sistematizados como os da experiência vivida pelos alunos, numa perspectiva crítica.

Pelo exposto e tendo em vista a necessidade da inclusão social dessas pessoas que aspiram à uma educação de qualidade e a importânia da construção de um novo perfil identitário para a EJA, cremos que é fundamental que se encontre, na forma da lei e na prática, alternativas de atendimento educacional, em termos de acesso e permanência nas escolas, desse contingente populacional.

\section{A EDUCAÇÃO DE JOVENS E ADULTOS E A LEGISLAÇÃO}

O problema do analfabetismo no nosso País é uma questão recorrente, apesar das tentativas de erradicá-lo. Resulta da ineficiência do nosso sistema educacional e de políticas públicas inadequadas, materializadas em programas e campanhas descontinuadas, que apareceram para erradicar o analfabetismo tão antigas quanto ineficientes, desde o primeiro programa oficial criado em 1947.

Flecha (2001) da Universidade de Barcelona, Espanha, discute no seu trabalho, que o desenvolvimento de habilidades comunicativas nos jovens e adultos é possível através da escola, quando os sujeitos iniciam seus processos formativos. Todas as pessoas possuem habilidades comunicativas, entendidas como aquelas que permitem a comunicação e atuação dos sujeitos no contexto em que vivem. 
Campanhas, mobilizações, movimentos políticos marcaram as tentativas de erradicação do analfabetismo no nosso País, alguns mais efetivos, de longa duração como a Campanha de Educação de Adultos e Adolescentes ${ }^{4}$, o Programa Nacional de Alfabetização ${ }^{5}$ e o MOBRAL ${ }^{6}$, dentre outros (OLIVEIRA, 2007).

Entender o processo de avanços e retrocessos na formulação das campanhas, projetos e programas de alfabetização de jovens e adultos que tramitaram ao longo da história da educação brasileira é refletir sobre a ideologia contida nesses programas oficiais. É também, procurar entender a história institucional da educação popular no Brasil, mergulhando na compreensão de todos os mecanismos formais e ocultos que atuaram e ainda vêm atuando nos caminhos políticos que direcionam tais políticas.

A antiga Lei de Diretrizes e Bases da Educação Nacional, Lei n ${ }^{\circ}$ 5.692, promulgada em 1971, incluiu pela primeira vez na história das legislações educacionais, um capítulo destinado à EJA, então chamada de ensino supletivo, estabelecendo no artigo 24 a função de "suprir a escolarização regular para adolescentes e adultos que não a tenham seguido ou concluído na idade certa" (BRASIL, 1997). O referido Ensino Supletivo foi regulamentado pelo Parecer $n^{\circ} 699^{7}$ cuja elaboração esteve sob a responsabilidade do então Conselheiro Valnir Chagas, do extinto Conselho Federal de Educação (CFE), hoje Conselho Nacional de Educação (CNE).

De acordo com Paiva (1987), nos idos de 1974, o Ministério da Educação e Cultura (MEC) propôs a implantação de Centros de Estudos Supletivos $(\mathrm{CES})^{8}$ como a solução mais viável para essa modalidade de ensino, atendendo ao tríplice objetivo de tempo (rapidez de instalação); custo (aproveitamento de espaços ociosos) e efetividade (emprego de metodologias adequadas).

A atual Lei de Diretrizes e Bases da Educação Nacional, Lei n ${ }^{\circ}$ 9.394, promulgada em 20 de dezembro de 1996, que veio substituir a anterior,

\footnotetext{
Programa de alfabetização implantado pelo então presidente Eurico Gaspar Dutra, em 1947.

Baseado no método do emérito educador Paulo Freire, implantado em 1964, no Governo João Goulart.

Movimento Brasileiro de Alfabetização, implantado no período da Ditadura Militar 1967-1978.

Visando regulamentar essa modalidade de ensino, o Conselheiro Valnir Chagas, elaborou o parecer que estabelecia normas e diretrizes para o ensino supletivo, onde cursos e exames eram previstos semestralmente para serem aplicados pelas secretarias estaduais de educação. O referido conselheiro recomendava, naquele Parecer, que os exames fossem gradativamente substituídos pelo atendimento através de cursos regulares (BRASIL, 1972).

8 A estrutura metodológica dos CES era baseada em módulos de auto-instrução. A freqüência nos referidos centros não era obrigatória e o sistema de avaliação previa a argüição em duas etapas: uma interna, ao final dos módulos, e outra externa, com exames especiais elaborados pelos sistemas educacionais (PAIVA, 1987).
} 
Lei $n^{\circ}$ 5.692, de 1971, estabelece novas diretrizes para a EJA. O Parecer do Conselho Nacional de Educação e da Câmara de Ensino Básico, tendo como relator o Dr. Jamil Cury, após ouvir as representações nacionais e especialistas sobre o assunto em todo o Brasil, consolidou a política do direito à educação para todos os jovens e adultos que não tiveram escolarização na idade certa. O referido Parecer estabeleceu que os sistemas de ensino estaduais e municipais terão autonomia para normatizar os cursos de EJA, inseridos na condição de educação básica regular. Ao mesmo tempo, enquanto modalidade, a EJA assume uma identidade própria para atender aos processos educacionais de alunos muito diferenciados em relação à idade, classe, sexo, raça, cultura e experiência de vida, conforme estabelecido no seu artigo 37 :

os sistemas de ensino assegurarão gratuitamente aos jovens e adultos, que não puderam efetuar os estudos na idade própria, oportunidades educacionais propriadas, consideradas as características do alunado, seus interesses, condições de vida e de trabalho, mediante cursos e exames (BRASIL, 1996, p. 27833-27841).

$\mathrm{Na}$ legislação, a EJA deve assegurar aos seus egressos a continuidade dos estudos e inserção no mundo produtivo, com as mesmas condições dos alunos que concluem o ensino fundamental e médio, nos cursos seriados. O Parecer $n^{\circ} 11$ - CNE/CEB (BRASIL, 2000) considera que essa modalidade de ensino deve receber um tratamento diferenciado dada a especificidade própria. Daí porque a estrutura do Parecer apresenta, além da introdução, tópicos referentes aos fundamentos e funções, as bases legais das diretrizes curriculares nacionais da EJA (bases histórico-legais e atuais), trata também da educação de jovens e adultos hoje (cursos de EJA, exames supletivos, cursos a distância e no exterior, plano nacional de educação), bases históricosociais da EJA, iniciativas públicas e privadas, indicadores estatísticos da EJA, formação docente para a EJA além de refletir sobre o direito à educação desse contingente populacional.

Como alicerce dessa educação, destacam-se as funções relacionadas ao principio de igualdade de educação para todos sem discriminação (função reparadora); restabelecimento das mesmas oportunidades para os estudantes que se encontram em distorção série - idade (função equalizadora); possibilidades de apropriação, atualização e utilização de conhecimentos por toda a vida (função qualificadora). 
$\mathrm{Na}$ lei atual, o sentido da EJA assume a condição de uma educação que qualifica, ao invés de suprir, desaparecendo com isso a noção de supletivo. A atual LDB portanto, passa a denominar "educação de jovens e adultos", o que a lei anterior chamava de "ensino supletivo".

No entanto, ao definir as formas de concretização dessa educação para os que a ela não tiveram acesso na idade própria, a legislação volta a falar em cursos e exames supletivos, que compreenderão a base nacional comum do currículo, habilitando ao prosseguimento de estudos em caráter regular.

A novidade mais expressiva, no capítulo referente à educação de adultos na atual lei, é a diminuição dos limites anteriormente fixados em 18 e 21 anos para respectivamente 15 e 18 anos de idade, para que jovens e adultos se submetam a exames supletivos em nível de ensino fundamental ou médio, porém, o espírito da lei anterior não foi revogado.

$\mathrm{Na}$ legislação atual a função compensatória da educação de adultos fica evidenciada, quando deixa claro sua finalidade de atender a uma clientela de baixa renda, sem escolarização, com o objetivo explícito de complementar situações iniciais de escolarização não suficientemente resolvidas. A conclusão evidente é que a expressão da lei anterior, como exposto pelo artigo 38, não foi revogada (BRASIL, 1996).

Pelo exposto, urge que se busquem caminhos alternativos e, na prática, formas inteligentes e arrojadas de atender às exigências quantitativas e qualitativas nacionais em termos de formação profissional e continuada dos professores de EJA, para dar conta dos desafios apresentados nesse nível de ensino.

\section{UNIVERSIDADE E FORMAÇÃO DOCENTE PARA O EJA}

Como já frisado anteriormente, precisamos de uma outra visão paradigmática para o enfrentamento dos desafios estruturais dessa sociedade informática e para o atendimento das exigências atuais em termos de educação. A questão está em não adotarmos a inovação tecnológica para dar apoio á educação tradicional, mas para romper com o monopólio das tecnologias expositivas, buscando uma educação que favoreça a construção do pensamento crítico e reflexivo do alunado e o repensar de novos valores.

É necessário que as instituições substituam os velhos paradigmas transmissivos pelo paradigma emergente que favorece a produção coletiva 
do conhecimento, como condição para que as vozes minoritárias sejam escutadas, sentimentos partilhados e todos possam ter lugar nessa sociedade plural.

Neste contexto, a universidade precisa repensar seus objetivos, conteúdos e práxis para que possa dar conta dos desafios que lhe são apresentados, principalmente, nessa modalidade de ensino.

Iniciamos a discussão desse sub tema pelas seguintes questões: quem educa o educador de jovens e adultos? Estão as universidades escutando as demandas sociais e políticas no que tange ás solicitações de um novo modelo de formação e de novas práticas educativas?

A formação de professores para a EJA, face à realidade apresentada no País, sobretudo nas regiões menos desenvolvidas do Brasil, exigiu que a atual, Lei $\mathrm{n}^{\circ}$ 9.394/96, aumentasse de cinco para dez anos, o tempo de aquisição do diploma desses profissionais.

Vale destacar que a totalidade dos professores de jovens e de adultos que ensina na zona rural representa justamente os que padecem de um maior isolamento profissional, e mais carecem das mudanças educacionais. Esses professores, mal remunerados e mal preparados, denunciam com as suas práticas as discrepâncias existentes nos processos formativos do ensino.

Sabe-se, no entanto, que os professores têm sido responsabilizados sozinhos pelo fracasso escolar, porém isso é um pressuposto inteiramente injusto, pois sua contribuição a esses resultados sinistros deve ser analisada juntamente com outros fatores intervenientes contextuais, culturais e sociopolíticos.

Esses professores, mal remunerados e mal preparados, denunciam com as suas práticas as discrepâncias existentes nos processos formativos do ensino, fruto de uma política de formação docente que se concretiza em projetos fragmentados, não satisfazendo às exigências de desenvolvimento profissional dos professores, e não respondendo às necessidades da sociedade tecnológica. O relato da pesquisa que se segue, comprova essas afirmativas.

\section{EDUCAÇÃO DE JOVENS E ADULTOS NA BAHIA: PESQUISA E REALIDADE}

Ao avaliar o Programa Educar para Vencer tínhamos a intenção de tornar visível o cotidiano das classes de Regularização de Fluxo e de Aceleração do referido programa, alimentávamos o desejo de desvendar, por trás da 
análise dos documentos, uma realidade prioritária, somente perceptível através da sensibilidade e da paixão

A avaliação de um programa ou projeto exige do avaliador um processo reflexivo e sistemático de indagação da realidade que impõe a necessidade da negociação, de diálogo e de consenso, levando-se em conta a heterogeneidade ideológica dos professores, a diversidade de ações e o perfil sócioeconômico dos alunos.

Quando analisamos o Programa Educar para Vencer, desvendamos a distância entre as propostas oficiais anunciadas e a realidade investigada, nas cidades e nas classes onde o referido programa se operacionalizou. Ao falarmos da distância entre o que está proposto teoricamente nos documentos oficiais da Secretaria de Educação e a realidade investigada, estamos comentando sobre a inadequação do programa ao contexto onde está inserido e, portanto, estamos nos referindo à falta de respostas adequadas às necessidades reais da comunidade escolar.

No papel de observadora, procurei entrevistar os sujeitos, escutar seus discursos, as intenções implícitas nas suas falas, aspectos que me chamaram mais atenção do que as questões semi-estruturadas da entrevista que elaborei. Como nos diz com muita propriedade Santos (1998, p. 93):

A pretensão de quantificar a realidade, longe de reconstruí-la rigorosamente, o que faz é deformá-la e descontextualizá-la. Do nosso ponto de vista, o importante é a realidade e a atenção prioritária ao discurso dos fatos e o sentido das entrelinhas.

Constatamos quão importante é a capacidade de inferir, no conteúdo dos discursos dos sujeitos. Muitas vezes faz-se necessário transcender o mero conteúdo sintático das suas falas, através de entrevistas e observações, para buscar relações entre o nível semântico e o pragmático, fazendo indagações sobre a própria realidade.

Dentre os instrumentos que foram utilizados, as entrevistas buscaram investigar os conceitos que os professores e gestores faziam a respeito das competências que um professor deve mobilizar na sua prática docente.

Um resultado interessante revelado na pesquisa, foram os argumentos usados pelos professores para expressar suas expectativas profissionais, suas representações a respeito do desempenho do alunado, seus conceitos sobre as competências requeridas ao professor alfabetizador, dentre outros. Para os professores entrevistados as principais qualidades que um professor(a) 
alfabetizador(a) deve reunir é o compromisso e responsabilidades profissionais, conhecimentos na área, além dos laços de afetividade e amizade com os alunos.

No entanto, nas observações que realizamos, as práticas docentes revelam quão esvaziados de conteúdos e de saberes se encontram esses docentes e quão afastados estão das competências exigidas a esses profissionais pela sociedade contemporânea.

Sem dúvida, ninguém está satisfeito com os resultados da escola. Observamos neste estudo que, sentindo-se "bodes expiatórios", os docentes põem a culpa nos alunos, no seu despreparo, bem como no desinteresse e desarticulação das famílias. Os administradores e gestores apontam, ora para a falta de compromisso dos professores, ora para a irresponsabilidade do Estado e/ou para os salários aviltantes. Os docentes, por outro lado, criticam a direção das escolas e a atuação dos coordenadores. E, nesse jogo, onde todos estão insatisfeitos e jogando a culpa nos outros parceiros, como fica a educação, como está sendo tratado o destino desde jovens e adultos do nosso Estado? Sem dúvida, é necessário uma reflexão e discussão conjunta do problema, com todos os setores envolvidos.

Pelos depoimentos dos sujeitos envolvidos (professores, diretores, e coordenadores) constatamos a falta de estrutura necessária nas classes e/ou até a inexistência de uma estrutura mínima de salas e equipamentos nos locais onde o programa está implantado. Observamos também a carência de recursos humanos e materiais didático-pedagógicos nas classes investigadas.

Quanto á análise das opiniões favoráveis ou desfavoráveis expressas pelos alunos à respeito da escola, vimos, pelos resultados apresentados, que eles ainda acreditam no papel significativo que a escola tem na mudança de qualidade de vida mas, paradoxalmente, dizem que as atividades nela realizadas são de memorização e que não conduzem à construção da leitura e escrita de forma significativa. De fato, observou-se que a escola não está provocando mudanças no processo de alfabetização dos jovens e adultos, pois as práticas docentes não conduzem á uma alfabetização crítica e à aprendizagem dos usos sociais da língua.

A formação teórico-prática inicial recebida pelos professores da Bahia não é suficiente para afrontar a realidade social e cultural, nos contextos onde esses professores desenvolvem suas atividades docentes, conforme 
podemos também onfirmar no nosso trabalho de investigação anterior (OLIVEIRA, 2001).

Além disso, no referido trabalho de pesquisa também destacamos os três elementos que nos permitem caracterizar com segurança, os três maiores problemas da educação de jovens e adultos na Bahia: 1) a inadequada preparação dos profissionais de educação de jovens e adultos; 2) os baixos salários percebidos e; 3) a precária qualidade de vida de todos os sujeitos implicados, em decorrência das condições socioeconômicas da população.

\section{À GUISA DE CONLUSÃO}

Vimos nas considerações anteriormente feitas, os problemas decorrentes da globalização e do avanço tecnológico. Tecemos considerações sobre o uso da tecnologia que, se por um lado possibilita a inserção dos sujeitos nos processos formativos essenciais á sociedade, por outro lado, promove a exclusão digital e a pobreza moral e material de muitos.

Discorremos sobre os grupos hegemônicos que detêm nas mãos o poder e o controle dos fluxos de comunicação e informação, usando a mídia para formar padrões de comportamento, massificar a opinião pública e legitimar o discurso hegemônico.

Discutimos o mais grave problema educacional baiano: o anafabetismo de jovens e adultos e a necessidade da universidade atentar para a necessidade de formação de um novo professor para esssa modalidade de ensino que desenvolva, além das competências ${ }^{9}$ relacionadas no âmbito do desenvolvimento profissional e pedagógico, outras competências relacionadas aos valores emergentes desta nova sociedade informática.

Apresentamos a pesquisa por nós realizada e mostramos que a análise de uma política pública se assenta numa concepção de avaliação democrática cujo processo institucional deve envolver todos os segmentos, conforme expressa Dias Sobrinho (2000, p. 63):

a qualidade de um programa está na medida em que se utiliza a avaliação como processo, inclue todos os segmentos envolvidos e delineia caminhos e soluções para a melhoria da formação dos alunos, possibilitando a qualidade do processo educativo.

9 O conceito de competência aqui concebido se refere á articulação de três registros de variáveis : saberes, esquemas de ação, um repertório de condutas e e rotinas doentes disponíveis segundo Charlier (2001). 
Quando se realiza uma avaliação apenas formal e externa de um programa, os instrumentos de natureza quantitativa, comumente utilizados pelos órgãos públicos, não refletem a realidade e podem conduzir a uma simplificação errada das mudanças que efetivamente ocorrem nos alunos jovens e adultos em processo de alfabetização

No desenrolar da pesquisa, inúmeros problemas ficaram evidenciados: desde os de natureza sócioeconômica dos sujeitos envolvidos, até aqueles relacionados ás condições internas da organização escolar. Aprofundamos algumas análises e outras deixamos indicadas, possibilitando a retomada do tema por outros pesquisadores.

Realizamos a análise dos fundamentos teórico-metodológicos do programa e seu reflexo no cotidiano das classes. A partir da análise e discussão dos resultados apresentados, afirmamos a necessidade do programa ter estratégias de ação mais coerentes com as diretrizes expressas nos documentos oficiais. Na nossa opinião, baseados no que observamos, os números nem sempre expressam toda a realidade e, quando esses dados são examinados nas cidades, vemos questões importantes desmentidas e desmistificadas.

Inúmeros problemas foram revelados através dos resultados da pesquisa: desde os de natureza sócioeconômica, envolvendo as baixas condições salariais em que vivem os alunos, o sub-emprego, as péssimas condições de habitação e moradia, as condições salariais dos professores, sua precária formação, estendendo-se até outros aspectos, como o total desconhecimento de alguns gestores/técnicos sobre o próprio programa. Tal fato sinaliza a verticalidade e centralização deste programa na administração da Secretaria de Educação do Estado da Bahia, deixando os gestores como meros executores, sem autonomia.

O novo paradigma educacional se caracteriza pela transferência de responsabilidades, cada vez maiores, da esfera federal para as esferas estaduais, municipais e em última instância, a escolar. Isso é preocupante, na medida em que, as políticas públicas enfatizam o comprometimento e a responsabilidade dos gestores no trato com a coisa pública. As escolas precisam tomar consciência da forma como estão sendo pressionadas a apresentarem resultados e como serão posteriormente responsabilizadas pelo sucesso ou fracasso escolares.

Quanto á avaliação, é importante a aceitação por parte da escola de avaliar-se a si mesma. Por outro lado, torna-se necessário introduzir um 
elemento de hetero-avaliação no programa, para que todas as instâncias sociais tomem conhecimento, participem do projeto de avaliação e mais que isto, fiscalizem a aplicação das verbas destinadas ao programa, que muitas vezes são controladas pelas prefeituras nem sempre honestas. Por isso defendemos a constituição de um conselho comunitário nos municípios onde o programa está implantado, constituído por pessoas idôneas e eleitas democraticamente, sem injunções políticas, para controlarem e fiscalizarem a implementação das políticas públicas de educação naqueles locais. Não basta que os governos expliquem como gastam o dinheiro, mas devem justificar esses gastos através de bons resultados.

Conforme comenta MacDonald (1976 apud SANTOS, 1999, p. 23) "o controle democrático da educação deve converter o processo avaliador num serviço de informação à comunidade sobre as características do programa educativo".

No estudo realizado, o aspecto mais comprometedor é o despreparo dos docentes que, apenas com a escolaridade média, negam tudo que teoricamente está aportado nas diretrizes curriculares nacionais para a educação de jovens e adultos.

Sabemos que a situação do analfabetismo é grave neste País e que os problemas da educação de jovens e adultos são de ordem política e só podem ser resolvidos a longo prazo. Seguramente os nossos professores não têm um juízo muito favorável sobre os processos de reforma da educação. Acreditam nos processos colaborativos e numa gestão mais autônoma, porém resistem implicitamente às mudanças, conforme detectado no nosso trabalho anterior de investigação.

Se pretendemos estimular o desenvolvimento profissional dos docentes e agilizar os processos de mudanças, o que devemos fazer primeiro é, sem dúvida, discutir uma nova concepção de formação do educador que possibilite contemplar dimensões relacionadas com o papel político, social e pedagógico dos professores nesta modalidade de ensino.

Defendemos a idéia de que o desenvolvimento profissional dos educadores de jovens e adultos deve ser concebido como um processo constante, ao longo da vida, que produzirá mudanças nas suas condutas, na forma de pensar, valorizar e atuar no ensino.

Nos cursos de formação não basta introduzir os professores nas teorias ou levá-los à apropriação do discurso pedagógico, pois a nossa experiência mostra que eles continuam agindo como sempre. Nas salas que observamos, 
os professores continuam fazendo ditado de palavras, com aulas sem planejamento, com uma pobreza de material muito grande, apesar dos cursos de capacitação que freqüentaram e sobre os quais opinam positivamente. Ficou patente que as metodologias utilizadas pelos cursos não instrumentalizam o professor para melhorar a qualidade do ensino nem tampouco operacionalizam o seu saber-fazer. $\mathrm{Na}$ verdade, os cursos promovidos pela Secretaria de Educação do Estado da Bahia ${ }^{10}$ são de excelente qualidade, mas se constituem de certa maneira, em pacotes de informação, como opinaram algumas professoras das cidades investigadas: "muita teoria e pouca prática".

Para se ter uma atuação coerente com a concepção construtivista e dialética da aprendizagem precisamos encontrar um caminho para alterar essa prática dos formadores. Uma das primeiras coisas a fazer é estabelecer um vínculo de confiança com a comunidade e com o professorado que vai receber a proposta. Isso exige reuniões e conversas para submeter a proposta aos docentes, utilizando uma metodologia onde os meios multimidiáticos participem.

Não temos dúvidas de que esse novo tempo exige mudanças e ações a curto prazo e, neste particular, o papel da universidade pode e deve ser relevante. Como ficou evidenciado na pesquisa, o nosso professor de jovens e adultos precisa ganhar muito mais e ter condições de trabalho adequadas. Assim, salário e valorização andam de mãos dadas. Essa premissa parece ser ignorada, na prática, pelos governos e a despeito da nova LDB exultar num dos seus capítulos a valorização dos profissionais em educação.

É necessário que a sociedade tome consciência de que o professor é um profissional indispensável, e que precisa ter um nível de qualificação superior ao exigido no passado. Se a sociedade exige uma escola de qualidade vai ter que assumir que isso requer também um professor preparado, com um perfil diferente do que vinha sendo proposto e também com um salário diferenciado. A luta não é somente da categoria, mas de toda uma sociedade que não pode prescindir de uma educação de qualidade (WEISZ, 2002).

10 Os cursos se referem ao período da pesquisa, de 2002 a 2006, governo Paulo Souto. 


\section{REFERÊNCIAS}

BRASIL. Lei Federal n. 5.692, de 11 de agosto de 1971. Fixa diretrizes e bases do ensino de $1^{\circ}$ e $2^{\circ}$ graus. Apresentação de Esther Pillar Grossi. Rio de Janeiro: Casa Ed. Pargos, 1997.

Lei n. 9.394, de 20 de dezembro de 1996. Estabelece as diretrizes e bases da educação nacional. Diário Oficial da União, Poder Executivo, Brasilia, DF, 23 dez. 1996. p. 27833-27841.

. Ministério da Educação. Conselho Nacional de Educação. Diretrizes curriculares nacionais para a educação de jovens e adultos. Parecer normativo, n. 11, de 10 de maio de 2000. Relator Conselheiro Carlos Roberto Jamil Cury. Disponível em: <http://www.deja.pr.gov.br/arquivos/File/ PCB11_2000.pdf>. Acesso em: 15 fev. 2007.

. Ministério da Educação. Conselho Federal de Educação. Ensino supletivo. Parecer normativo, n. 699, de julho de 1972. Relator Valnir Chagas. In: Educação no Brasil: textos selecionados. Brasília, 1976. p. 225-260.

CASTELLS, M. La Era de La Información: Economia, sociedad y cultura. Madrid: Alianza Editorial, 1997. (v. I-III). Trabajo original pu-blicado en 1996-1998.

CHARLIER, Évelyne. Formar professores profissionais para uma formação contínua articulad á prática. In: PERRENAUD, P.; PAQUAY, Léopold; ALTET, Marguerite e CHARLIER, Évelyne. Formando Professores Profissionais. Quais estratégias? Quais Competências? Porto Alegre: ArTmed Editora, 2001, p. 85-102.

BONETI, Lindomar Wessler. Políticas públicas por dentro. Ijuí: Editora Unijuí, 2006. p. 96.

DIAS SOBRINHO, J. Avaliação da Educação Superior. Petrópolis: Vozes, 2000. p. 45-87.

FLECHA, R. Comunidades de aprendizaje: sociedad de la información para todos, cambios sociales y algunas propuestas educativas. Barcelona: Universidade de Barcelona, 2001. p. 26. Mimeografado.

LÉVY, Pierre. As Tecnologias da inteligência: o futuro do pensamento na era da informática. Rio de Janeiro: Ed. 34, 1993.

MATOS OLIVEIRA, Maria Olívia. Necesidades y expectativas de los profesores alfabetizadores de Bahia. Tesina: Universidad Autónoma de Barcelona, 2001.

MATOS OLIVEIRA, Maria Olivia. Educação de Jovens e Adultos na Bahia: pesquisa e realidade. Salvador: EGBA, 2007.

PAIVA, Vanilda P. Educação Popular e Educação de Adultos. São Paulo: Edições Loyola, 1987. 
SANTOS, Milton. Por uma outra globalização: do pensamento único á consciência universal. 5. ed. Rio de Janeiro: Record, 2001.

SANTOS, Miguel Ángel. Hacer Visible lo Cotidiano: teoría, práctica de la evaluación cualitativa de centros escolares. Madrid: Akal Ediciones, 1998.

SANTOS, Boaventura S. Pela Mão de Alice: o social e o político na pósmodernidade. São Paulo: Cortez, 1999. p. 23-49.

WEISZ, Telma. O diálogo entre o ensino e a aprendizagem. São Paulo: Editora Ática, 2002. 


\section{A formação dos professores no Brasil e em Santa Catarina: do normalista ao diplomado na educação superior}

Leda Scheibe

Ione Ribeiro Valle

$\mathrm{Na}$ política educacional brasileira, aos avanços legais parecem contrapor-se, reiteradamente, recuos pragmáticos, que pouco têm contribuído para a democratização do sistema nacional de educação. Os dispositivos que se sucedem à promulgação das leis gerais para a educação nacional têm investido, sistematicamente, numa concepção técnico-profissionalizante de formação, definida pela ênfase nas competências docentes, muitas vezes confundidas unicamente com o fato de portar um diploma que comprove a habilitação para o exercício do magistério. A ênfase tecnicista ${ }^{1}$ adotada pela maioria dos dispositivos oficiais, apesar do seu caráter instável ${ }^{2}$, leva a perseguir uma padronização do perfil profissional, ao invés de reforçar a concepção científico-acadêmica, reivindicada por pesquisadores e pelas esferas representativas dos profissionais da educação (associações profissionais, associações científicas, sindicatos). Esta discute as diferentes formas de socialização profissional, consideradas centrais na consolidação da identidade dos professores.

Expressão empregada para caracterizar a influência da teoria do capital humano e do pensamento pedagógico americano.

2 Segundo Valle (2003, p. 236), com o objetivo de "construir um sistema unificado para o país, a administração federal impõe aos estados e municípios uma dinâmica permanente de adaptação a suas determinações. Ora, estes dispositivos aportam orientações e recomendações que não somente desconsideram a capacidade criativa dos estados e municípios mas impedem também sua autonomia político-administrativa". 
Embora os pesquisadores sejam unânimes ao mencionarem a insuficiência de estudos sobre os efetivos problemas educacionais do país e a grande distância entre o caráter acadêmico do ensino superior e a realidade da escola pública (VALLE, 2005), a história das políticas de formação docente, assim como a história do sistema de educação nacional, para o qual esta formação prepara, nos levam a uma constatação importante: os recuos pragmáticos que têm acompanhado os avanços da legislação não impedem certa melhoria no processo de formação de professores. Observa-se que esta não se deteriorou na medida da sua expansão quantitativa, pois o aumento do nível de exigência nos processos de recrutamento e a constituição progressiva da carreira docente foram sempre defendidos por uns e perseguidos por outros, ainda que com finalidades diversas e até mesmo antagônicas. Valle (2006, p. 179) assinala que "o propósito de constituir uma carreira para o magistério integra os objetivos das esferas administrativas, estando associado à idéia de corpo unificado considerada indispensável à ampliação de sua eficiência e produtividade”.

Além disso, preconizou-se o prolongamento da formação para o magistério das quatro primeiras séries do ensino obrigatório, restrita ainda ao ensino médio, mas que deve alcançar - o mais rapidamente possível - o nível superior. Tal ascensão supõe um maior engajamento da Universidade nas questões político-pedagógicas e administrativas que afetam as redes públicas de ensino, a fim de favorecer as transformações sociais e culturais reivindicadas nos diferentes momentos históricos.

Esta constatação nos autoriza a formular uma primeira hipótese: a profissionalização e a formação dos professores sempre estiveram no centro dos projetos e investimentos do Estado brasileiro, visando ao mesmo tempo organizar as massas, ampliar o controle sobre a escolarização da população e ampliar as oportunidades de acesso aos sistemas públicos de ensino. Tendo por referência a análise dos principais dispositivos legais que estabeleceram as políticas de educação para o país, examinaremos as diferentes etapas da formação docente, partindo do pressuposto que elas correspondem às mutações das prioridades e diretrizes do Estado brasileiro em termos de educação escolar, introduzidas ao longo do século XX.

Três fases, que não estão constituídas por rupturas ou descontinuidades mas por mudanças mais ou menos profundas na organização dos sistemas de ensino (em âmbito federal, estadual e municipal), parecem se destacar 
no movimento de formação dos professores brasileiros: a primeira começa com o advento da República (1889) e se prolonga até o início de 1960, preconizando uma formação de nível médio, considerada fundamental à escolarização das novas gerações. A educação passa a ser vista como um serviço público de responsabilidade do Estado, devendo organizar as massas e formar os cidadãos civilizados, visando o fortalecimento de uma sociedade que pretendia se tornar hegemônica; a segunda fase prossegue até os anos de 1980, estando centrada principalmente numa concepção tecnicista de formação profissional, que permanece circunscrita ao ensino médio. Esta fase se constitui sobretudo com a chegada dos militares ao poder em 1964 e a instituição de um regime autoritário e burocrático, período em que ocorre uma importante expansão da oferta escolar com a finalidade de ampliar o controle ideológico sobre as massas e prepará-las para responder às necessidades de um emergente mercado de trabalho, com fortes características monopolistas; e a terceira fase aparece claramente após a instalação da Nova República (1985), quando se propõe a formação para o exercício docente ao nível superior. Nesta fase é atribuída à educação escolar a missão de compensar o déficit educacional e social, acumulado pela baixa qualidade e produtividade dos sistemas públicos de ensino, e participar efetivamente da democratização da sociedade brasileira.

\section{UMA FORMAÇÃO DE NÍVEL MÉDIO PARA A ESCOLARIZAÇÃO E ORGANIZAÇÃO DAS MASSAS}

As escolas normais foram as primeiras instituições de formação de professores criadas no Brasil por iniciativa das províncias ainda durante o Império, após a independência do país em 1822. Elas permaneceram praticamente como únicas responsáveis pela formação docente até final dos anos de 1950. Um dos elementos centrais na organização das massas populares - a formação dos professores - adquiriu, no entanto, maior importância, com o advento da República, implicando um maior esforço no sentido de instalar essas escolas em todo o território nacional. Mas esse processo foi lento e gradativo, seguindo o ritmo do desenvolvimento social, político e econômico dos diferentes estados da federação.

A escola normal configurou-se como elemento essencial para a expansão do ideário republicano, em oposição ao ordenamento institucional do 
regime imperial. Os professores, que deveriam ser os difusores de uma nova visão de mundo inspirada no ideário positivista, precisavam ser selecionados e preparados para essa tarefa ou "missão", que tinha por objetivo alfabetizar toda a população e fortalecer o novo regime e seus beneficiários, ou seja, as oligarquias regionais (NÓBREGA, 2002).

No entanto, a conjuntura social, política e econômica da Primeira República, que prevaleceu até 1930, não favorecia a expansão da educação escolar. O federalismo descentralizado, o Estado oligárquico, subordinado aos interesses dos grupos dominantes das regiões produtoras e exportadoras de café, trouxe grandes discrepâncias no desenvolvimento das diversas regiões e estados. Estes que acabavam organizando, ao sabor de suas condições específicas e de seus reformadores, os seus sistemas de ensino (SCHEIBE; DANIEL, 2002). Não surpreende, pois, o papel paradigmático que o Estado de São Paulo representou no campo educacional para os demais estados brasileiros nos primeiros 30 ou 40 anos da República. Comissões estaduais de todos os cantos do Brasil dirigiam-se a São Paulo para conhecer a organização do seu serviço de instrução pública, ao mesmo tempo em que "missões" de professores paulistas visitavam os estados para ajudar a reorganizar o seu ensino.

A primeira tentativa oficial de garantir uma base comum nacional para a formação de professores ocorreu durante o Estado Novo, instituído pela ditadura de Getúlio Vargas (1937-1945), através das Leis Orgânicas de Ensino, promulgadas de 1942 a 1946. Convocou-se, para a sua preparação, a I Conferência Nacional de Educação, em 1941. Essas leis tiveram a finalidade de suprir a ausência de normas centrais e delinear um processo de regulamentação, em âmbito federal, de políticas públicas educacionais (TANURI, 2000).

A Lei Orgânica do Ensino Normal, aprovada em 1946, foi assinada logo após o fim da ditadura Vargas, tendo preconizado, sem grandes inovações, uma certa uniformidade na formação para o magistério (BRASIL, 1946). Essa lei consagrava o que já vinha sendo adotado em vários estados da federação em termos de educação. O ensino normal estava dividido em dois ciclos: a) o curso de formação de "regentes" do ensino primário, em quatro anos, para funcionar em escolas normais regionais e; b) o curso de segundo ciclo, em dois anos, para formar o professor primário, a ser ministrado nas escolas normais e nos institutos de educação. Esta lei, com 
o propósito de dar uniformidade à formação de professores nos vários estados, estabeleceu para as escolas normais um tratamento de escola profissional: cada uma delas deveria manter um grupo escolar, um jardimde-infância e um ginásio oficialmente reconhecido, visando estabelecer uma relação com a prática. As escolas regionais, destinadas a alunos com a idade mínima de 13 anos, portadores de certificados primários (com a duração de cinco anos de estudo), deveriam manter ao menos duas escolas primárias isoladas (TANURI, 2000).

Ao ser promulgada a Constituição de 1946, poucos meses após a aprovação da Lei Orgânica do Ensino Normal, é retomada no país uma orientação descentralizadora e liberal. A grande maioria dos estados, porém, ainda que livres para regulamentar o seu ensino primário e normal, tomou essa lei como modelo para a organização do seu sistema de formação de professores.

Embora a primeira Escola Normal do País já tenha sido criada na província do Rio de Janeiro em 1835, a maioria das províncias brasileiras não tinha mais do que uma ou quando muito duas escolas normais públicas até o final deste período do Império, durante o qual formou-se precariamente um número reduzido de professores em todo o país (TANURI, 2000). Em Santa Catarina foi criada a primeira Escola Normal em 1880, mas esta não manteve um funcionamento regular, datando do início do período republicano (1892), a criação da Escola Normal Catharinense, que mais efetivamente inaugurou e instituiu a formação de professores no Estado.

Schaffrath (2002), ao estudar o currículo e os programas de ensino desta escola, verificou nestes a valorização sobretudo do conhecimento científico, da cultura literária, de uma formação geral e enciclopédica, enfatizando conteúdos morais e cívicos laicos. Constatou, portanto, a forte influência do positivismo, que permeou a ideologia republicana, cujo ideário estabeleceu desde cedo uma forte relação de identidade entre instrução pública e fortalecimento da nacionalidade, da cidadania e do ordenamento social. Segundo alguns autores, eram adotadas práticas docentes e administrativas - seleção de alunos, castigos e recompensas, valorização da moralidade, discriminação do trabalho feminino - que estavam longe do ensino e composição das disciplinas oferecidas. Estas, "no conjunto de procedimentos curriculares da escola, ajudavam a desvelar 
bases ideológicas sob as quais se assentava este modelo de instituição escolar, formador de professores" (SCHAFFRATH, 2002, p. 110).

Em Santa Catarina houve importante reestruturação do ensino, inclusive na reorganização do Curso Normal, seguindo as linhas básicas da instrução pública do Estado de São Paulo. Durante o governo de Vidal Ramos (19101914), por exemplo, o professor Orestes Guimarães, formado na Escola Normal da Praça da República de São Paulo, foi nomeado Inspetor Geral de Ensino no Estado, cargo que ocupou durante 10 anos, com a anuência do Governo de São Paulo, para assessorar e modernizar a reforma educacional catarinense (FIORI, 1991).

As reformas educacionais paulistas foram, portanto, paradigmáticas para o país e para Santa Catarina. O currículo da Escola Normal Secundária foi sendo modernizado a partir do que ocorria naquele Estado, destacando-se a ênfase nas matérias científicas, ao mesmo tempo em que maiores exigências de cultura enciclopédica passaram a ser requisito para ingressar no curso. Já os “cursos complementares”, pensados inicialmente para complementar o ensino primário, se tornaram uma forma adicional de preparar professores para as escolas preliminares, concretizando-se com isso dois níveis de formação de professores para as séries iniciais. Esta estrutura foi justificada como necessária para expandir o sistema de formação docente e prover o ensino primário de pessoal habilitado. A exemplo do que ocorreu em São Paulo, em Santa Catarina, na década de 1930, as Escolas Complementares passaram a denominar-se Escolas Normais Primárias e as Escolas Normais passaram a se chamar Escolas Normais Secundárias.

\section{DA TRADIÇÃO NORMALISTA À FORMAÇÃO TÉCNICO-PROFISSIONAL}

A primeira Lei de Diretrizes e Bases da Educação Nacional (LDB) aprovada pela Câmara Federal em 1961, após uma longa seqüência de discussões e concessões, foi o resultado de uma estratégia de conciliação entre os interesses privatistas e de defensores do ensino público (BRASIL, 1961). Os acordos ${ }^{3}$ firmados entre esses grupos beneficiavam a elite em

\footnotetext{
Como assinalou Amado (1973), os procedimentos conciliatórios predominaram durante todo o processo de elaboração da lei. Eles definiram então os diferentes níveis da estrutura do sistema de ensino (federal, estadual e municipal), bem como suas áreas respectivas de competências político-administrativas.
} 
prejuízo do interesse geral da população no que concerne à escolarização. A nova lei não trouxe modificações significativas para a formação docente, pois o ensino normal continuou sendo o único nível de preparação dos professores do ensino obrigatório (de $1^{\mathrm{a}}$ a $4^{\mathrm{a}}$ séries). No que se refere à estrutura das escolas normais, nota-se que a maior parte dos estados conservou o sistema dual, com escolas normais constituídas de dois níveis de formação: o ginasial, com conteúdos gerais aos quais se acrescentava uma preparação pedagógica que conferia um diploma de "Regente do ensino primário"; e o colegial, que era consagrado aos aprofundamentos, no fim do qual o aluno obtinha o diploma de "Professor primário".

Com a reordenação no campo político-administrativo e pedagógico, que ocorreu após a implantação do regime militar de 1964, o modelo de formação de professores foi em grande parte descaracterizado, embora tenha permanecido centrado no nível médio, assim permanecendo até o início dos anos 1990. A Lei ${ }^{\circ}$ 5.692/71 reformou o ensino de primeiro grau, cuja obrigatoriedade passa de quatro a oito anos, e o ensino de segundo grau, transformando a escola normal numa das habilitações profissionais deste nível de ensino (BRASIL, 1971). Esta habilitação passa a integrar a profissionalização obrigatória adotada para todo o ensino médio (VALLE, 2003).

A escola normal tradicional deixou de existir. A "habilitação magistério" regulamentada em 1972, que a substituiu, foi organizada de forma a apresentar um núcleo comum de formação geral (constituído de disciplinas da área de comunicação e expressão, estudos sociais e ciências) e uma parte de formação especial (abrangendo os fundamentos da educação, a estrutura e o funcionamento do ensino de primeiro grau, e a didática que incluía a prática de ensino). Fica evidente nesses dispositivos legais a forte influência da concepção tecnicista que caracterizou o pensamento educacional oficial nesse período, destacando-se a fragmentação do curso, a grande diversificação de disciplinas no seu currículo com prejuízos para uma formação geral e o esvaziamento da habilitação em termos de saberes pedagógicos consistentes.

A “desmontagem" dos cursos de formação de professores em nível médio provocou um movimento denominado de "revitalização do ensino normal”, que estimulou estudos e propostas de ação efetivadas tanto pelo Ministério de Educação (MEC) como pelas secretarias estaduais, com a finalidade de 
reverter o quadro de descontentamento em relação a essa habilitação. Dentre as propostas do MEC, destaca-se o Projeto dos Centros de Formação e Aperfeiçoamento do Magistério (Cefam), elaborado em 1982, que foi adotado em alguns estados da federação. Esse projeto propiciou alguns avanços na melhoria da qualidade do ensino, como enriquecimento curricular, articulação entre as disciplinas, exame seletivo para ingresso no curso, início da formação docente desde a $1^{a}$ série do ensino médio, trabalho coletivo no planejamento e na execução do currículo e, ainda, a possibilidade de funcionamento em tempo integral, dedicado ao mesmo tempo às atividades regulares do currículo e às de aprofundamento e estágio.

A partir dos anos 1980 houve também uma progressiva remodelação do curso de pedagogia, nível superior ${ }^{4}$, visando adequá-lo à preparação do professor para a educação infantil e os anos iniciais do ensino fundamental ( $1^{\mathrm{a}}$ a $4^{\mathrm{a}}$ séries). Esse curso formava, através das habilitações oferecidas, os denominados “especialistas” em educação (supervisores, administradores, orientadores e inspetores educacionais), os professores para a escola normal e, a partir de 1970, os professores para a "habilitação magistério". A participação do movimento docente, organizado em torno da Associação Nacional pela Formação dos Profissionais da Educação (Anfope) ${ }^{5}$, foi decisiva na defesa da formação de professores para as séries iniciais. Parecia evidente a carência de bases conceituais e metodológicas para a constituição da identidade dos profissionais da educação brasileira.

\section{UMA FORMAÇÃO SUPERIOR PARA O EXERCÍCIO DO MAGISTÉRIO - SÉRIES INICIAIS}

Desde os anos de 1970, numerosos movimentos e manifestações eclodiram por toda sociedade brasileira, visando à rendição imediata do regime autoritário. Uma transição política se desenhava. Então, sempre atentas a

\footnotetext{
Sobre a formação pedagógica do professor licenciado, ver SCHEIBE (1983).

No final da década de setenta, iniciou-se um movimento pela reformulação dos cursos de formação de educadores no Brasil que partiu das discussões sobre o Curso de Pedagogia, e ampliou-se para a discussão mais geral sobre a formação de todos os professores. Este movimento articulou-se mais fortemente em 1980, com a instalação do Comitê Nacional Pró Formação do Educador, durante a I Conferência Brasileira de Educação em São Paulo e teve continuidade com a criação da Associação Nacional pela Formação dos Profissionais da Educação (ANFOPE), em 1990, entidade que vem liderando desde então a construção coletiva de uma Base Comum Nacional para a formação destes profissionais.
} 
pressões sociais, as camadas dominantes prepararam cuidadosamente esta transição, reativando a velha prática das alianças. Após o fracasso das mobilizações de 1984 reivindicando as eleições diretas em todos os níveis, os candidatos civis Tancredo Neves (líder democrático) e José Sarney (conivente com o poder militar) são eleitos por uma votação indireta para a Presidência e a Vice-Presidência da República, respectivamente. Tancredo Neves fica gravemente doente na véspera da posse e Sarney assume interinamente em 1985 o cargo de Presidente da República. Neves morre e Sarney ocupa o cargo até o fim do mandato (1990). Apesar deste episódio na transição do regime, o quadro institucional da Nova República propunha-se a retomar os direitos políticos característicos de uma democracia liberal, que haviam sido suprimidos pelo regime autoritário. Era evidente que a democratização do Estado brasileiro não podia se fazer sem uma transformação profunda nas concepções e estruturas de poder fortemente cristalizadas no país. A consolidação do sistema de educação nacional, que permanecia fortemente centralizado no âmbito federal e dos estados, estava no centro dessas transformações, assim como a definição de uma política de formação de professores para todos os níveis do ensino.

O ideário crítico sobre o que deveria ser um efetivo projeto nacional de educação, que foi se constituindo ao longo das últimas décadas, normalmente à margem das deliberações oficiais, foi contemplado em vários pontos pela Constituição Federal, promulgada em 1988. Esta forneceu um arcabouço jurídico capaz de permitir as transformações institucionais e educacionais, reivindicadas por amplos setores da sociedade brasileira. No entanto, a versão final da nova Lei de Diretrizes e Bases da Educação Nacional (aprovada em 1996) colocou vários obstáculos à implementação das propostas elaboradas pelo conjunto da sociedade civil, organizada em torno de um projeto de educação para o Brasil. Esta lei não desconsiderou todos os consensos do rico debate dos anos 1980, mas os traduziu, muitas vezes, para uma outra lógica de desenvolvimento, onde descentralização, por exemplo, passou a significar principalmente uma desconcentração da responsabilidade do Estado ${ }^{6}$. Autonomia, por sua vez, passou a ser compreendida como liberdade para captar recursos financeiros. A igualdade foi entendida como eqüidade, e a cidadania crítica, como cidadania

\footnotetext{
6 Sobre o movimento democratização-descentralização-municipalização, ver Valle, Mizuki e Castro (2004).
} 
produtiva, o que supõe uma adequação às exigências e necessidades do mercado (SHIROMA e outros, 2000).

Para Mello (1999), intelectual brasileira que esteve à frente das reformas educacionais da década de 1990, é preciso estabelecer uma política nacional de formação, estruturada em um consenso construído pelo conjunto dos setores educacionais interessados. O primeiro passo, segundo ela, consiste em estabelecer um acordo sobre o caráter nacional da formação dos professores, que é do interesse da nação, pois desta formação depende a produção e a reprodução do processo educacional. A formação aparece, nos diversos documentos da reforma, como estratégia para a unidade nacional, o pleno exercício da cidadania, a integração e a inclusão social, a sobrevivência em uma economia mundial competitiva. Somente uma forte coesão em torno da natureza da formação político-pedagógica, tomada como interesse nacional, poderá dar uma total eficiência às diretrizes, aos referenciais ou às recomendações sobre o currículo e sobre a organização pedagógico-institucional dos cursos de formação. Eis aí o conteúdo da política de formação dos professores em implantação no Brasil e que se apresenta como um grande desafio à pesquisa educacional.

\section{NOVAS DIRETRIZES PARA A FORMAÇÃO DE PROFESSORES}

A nova Lei de Diretrizes e Bases da Educação Nacional, LDB Lei $n^{\circ}$ 9.394/96, enfrentou, portanto, desde sua implantação, uma situação de diversidade de concepções e uma pluralidade de instituições e de cursos formadores dos profissionais para a escolarização inicial, na tentativa de satisfazer aos diversos interesses postos pela sociedade. O estabelecimento de um acordo sobre o caráter nacional da formação dos professores, num país de profundas desigualdades educacionais, sociais e culturais, encontrou um maior peso no favorecimento das forças econômicas, contraditórias por natureza. Além desta situação, evidenciou-se também um imenso contingente de professores leigos ainda remanescentes no país. As regulamentações decorrentes dessa lei revelaram claramente a intenção de impor um modelo de formação docente, que, embora apareça vinculado ao nível superior, apresenta-se em grande parte desvinculado de uma formação universitária, passando a constituir-se numa preparação técnico- 
profissionalizante, que acrescenta pouco à formação de nível médio, até então vigente (SCHEIBE, 2003).

Foi então regulamentada uma nova institucionalização para a formação dos professores no Brasil, a saber: os institutos superiores de educação e os cursos normais superiores, que, em razão de suas características pedagógicas e de infra-estrutura, contribui para a desvalorização do magistério, colocando em xeque a melhoria da qualidade do ensino brasileiro, que vêm sendo reivindicada há várias décadas. Os programas de formação implementados por estas novas instâncias educativas reduzem o tempo de duração dos cursos, simplificam o trabalho pedagógico e descaracterizam a identidade dos profissionais do magistério, superpondo-se à estrutura de formação já existente nas universidades brasileiras. O que se observa então é que a sólida formação universitária, amplamente reivindicada, vem de forma tácita sendo procrastinada.

O estudo das concepções e das políticas de formação tem-nos possibilitado perceber que, apesar da elevação dos níveis de escolarização do corpo docente (VALLE, 2003), há dificuldades em romper com o processo histórico de desvalorização social dos professores, seja pelos recuos pragmáticos da própria legislação ao se enfrentar com os preceitos de uma democracia mais formal do que real, seja pela precariedade das condições de trabalho, pelos salários aviltantes, pela falta de estabilidade profissional, pelas dificuldades de constituição da carreira docente. No entanto, persiste uma concepção idealista em relação ao exercício do magistério, oscilando entre uma "identidade vocacional" e uma "identidade profissional" (VALLE, 2002), que é corroborada pelos professores, por suas esferas representativas e pelas instâncias de administração da educação.

O avanço qualitativo efetivamente democratizante, decorrente da necessidade de elevação da formação inicial para o nível superior não vingará se houver concessões a programas de formação aligeirados. Isto não significa negar a existência de situações emergenciais, relativas a carências de docentes em certas regiões e para certas áreas, o que deve ser enfrentado através de uma sólida articulação entre as universidades, o Ministério da Educação, as secretarias de Estado e as secretarias municipais de educação. Mas não parece racional, mesmo do ponto de vista econômico e gerencial, o esvaziamento das estruturas existentes e sua substituição por novas 
estruturas. A oferta de formação a custo mais baixo representa a curto e médio prazo desperdício de recursos físicos, materiais, humanos e financeiros.

Os pesquisadores brasileiros, representados na Anfope, consideram importante continuar apontando para a necessidade de acompanhar e avaliar as experiências de formação em andamento hoje nas diferentes instituições de ensino superior dos diversos estados brasileiros, tendo como parâmetro os princípios de uma base comum nacional para a formação dos professores, que vem sendo amplamente discutida e socializada pela comunidade educacional. Tal acompanhamento diz respeito tanto aos cursos regulares (diurnos e noturnos), como aos cursos emergenciais, que são hoje ofertados numa proporção realmente preocupante, seja em regime presencial especial (fim de semana, em férias), ou cursos a distância.

A oferta de cursos de formação de professores a distância supõe a criação de espaços para o aprofundamento conceitual de um novo tipo de ensino e de aprendizagem. Este é um campo extremamente complexo que envolve novas concepções de aprendizagem interativa, por exemplo, e exige a ressignificação das abordagens pedagógicas do fenômeno educativo. Os seguintes pontos merecem hoje particular atenção na sua oferta: 1 . definir melhor a dimensão/concepção de tutoria dos programas de formação continuada à distância; 2 . buscar estabelecer uma cota adequada de educação presencial como forma de garantir a socialização e o trabalho coletivo dos professores; 3 . definir mais claramente o caráter de programa emergencial desses cursos, vinculando-os às regiões menos atendidas, bem como explicitar o papel das Faculdades/Centros de Educação na sua concepção, elaboração e desenvolvimento (ASSOCIAÇÃO..., 2000).

Os professores, reunidos nos encontros da Anfope, têm demonstrado o entendimento de que cabe tanto aos cursos de formação inicial quanto aos programas de formação continuada usar articuladamente tecnologias educacionais, não como substitutivos da modalidade presencial, mas como cooperativos, garantindo nesse processo a autonomia do trabalho dos professores em relação aos saberes escolares, aos materiais didáticos e às modalidades de avaliação do rendimento do aluno. Lidar com as novas linguagens e compreender as novas formas do trabalho material é um desafio colocado para os professores que entendem ser, hoje, a tecnologia uma realidade que impregna a vida de todos, envolvendo novas concepções de ensino e aprendizagem. Mas não representa, certamente, um valor em si mesma. 
Enfim, cabe assinalar que as propostas pelas quais luta o movimento docente nas últimas décadas - formação de qualidade, incentivo às faculdades e centros de educação como espaços privilegiados de formação de professores, construção da profissionalização e da autonomia e do desenvolvimento intelectual do docente -, precisam ser recuperadas neste momento, para que se transformem em políticas publicas. A discussão dessas propostas e o encaminhamento das sugestões de modificação devem ocorrer de forma organizada, participativa, abrangendo nossas entidades e associações acadêmicas e científicas e o conjunto das nossas instituições educacionais. Estes são compromissos urgentes que devemos assumir se desejamos efetivamente oferecer a população brasileira condições democráticas de acesso á um ensino de qualidade.

A valorização dos professores supõe formação continuada, condições de trabalho dignas e adequadas e um plano de carreira responsável e motivador, dimensões indissociadas do trabalho docente e da profissionalização do professor. Uma avaliação que não se insira nesses eixos ou que desconsidere a realidade concreta na qual se insere o professor e o funcionamento da instituição escolar, tende a ser inócua.

\section{REFERÊNCIAS}

AMADO G. Educação média e fundamental. Rio de Janeiro: José Olímpio, 1973.

ASSOCIAÇÃO NACIONAL PELA FORMAÇÃO DOS PROFISSIONAIS DA EDUCAÇÃO, 10., 2000, Belo Horizonte. Documento Final do VII Encontro Nacional da ANFOPE. Brasília: ANFOPE, 2000.

BRASIL. Lei n. 8.530, de 2 de janeiro de 1946. Lei Orgânica do Ensino Normal. Rio de Janeiro: 1946.

. Lei n. 4.024, de 20 de dezembro de 1961. Estabelece as diretrizes e bases para a educação nacional. Diário Oficial da União. Brasília: Gráfica do Senado, 1961.

. Lei n. 5.692, de 11 de agosto de 1971. Estabelece as diretrizes e bases para o ensino de $1^{\circ}$ e $2^{\circ}$ graus, e dá outras providências. Diário Oficial da União. Brasília: Gráfica do Senado, 1971.

. Lei n. 9.394/96, de 20 de dezembro de 1996. Estabelece as diretrizes e bases para a educação nacional. Diário Oficial da União. Brasília: Gráfica do Senado, v. 134, n. 248, p. 27833-41, 1996. 
FIORI, N. A. Aspectos da evolução do ensino público. Ensino público e política de assimilação cultural no Estado de Santa Catarina nos períodos imperial e republicano. Florianópolis: Editora da UFSC, $2^{a}$ ed. revisada, 1991.

MELLO, G. N. de. Formação inicial de professores para a educação básica: um revisão radical; documento principal versão preliminar para discussão interna. São Paulo: MEC, 1999, outubro/novembro.

NÓBREGA, P. Escola Normal, Ciência e Nacionalidade na Primeira República. In: SCHEIBE, L.; DAROS, M. D. Formação de professores em Santa Catarina. Florianópolis: NUP/CED, 2002.

SCHAFFRATH, M. A. S. A proposta curricular da Escola Normal Catharinense de 1892. In: SCHEIBE, L.; DAROS, M. D. Formação de professores em Santa Catarina. Florianópolis: NUP/CED, 2002.

SCHEIBE, L. A formação pedagógica do professor licenciado: Contexto histórico. Perspectiva, Florianópolis, v. 1, n. 1, ago./dez. 1983.

SCHEIBE, L. Políticas para a formação dos profissionais da educação neste início de século: Análises e perspectivas. REUNIÃO ANUAL DA ANPED, 26., 2003, Poços de Caldas. Anais... Poços de Caldas: ANPED, 2003. CDRom.

; DANIEL, L. S. Formação docente para a educação básica: um desafio para o ensino superior no século XXI. In: SCHEIBE, L.; DAROS, M. D. Formação de professores em Santa Catarina. Florianópolis: NUP/ CED, 2002.

SHIROMA, E. O.; MORAES, M.C. M.; EVANGELISTA, O. Política educacional. Rio de Janeiro: DP\&S, 2000.

TANURI, L. M. História da formação de professores. Revista Brasileira da Educação, Local, n. 14, p. 61-88, maio/jun/jul/ago. 2000.

VALLE, I.R. A era da profissionalização. Formação e socialização profissional do corpo docente de $1^{\mathrm{a}}$ a $4^{\mathrm{a}}$ série. Florianópolis: Cidade Futura, 2003.

. Da "identidade vocacional" à "identidade profissional": a constituição de um corpo docente unificado. In: Perspectiva: Sociologia e Educação. Revista do Centro de Ciências da Educação, 2002, v. 20, jul./ dez., p. 209-230, Número especial.

- Formação de professores: um esforço de síntese. In: Educar em

Revista. Curitiba, n. 25, jan./jun., p. 215-235, 2005.

- Carreira do magistério: uma escolha profissional deliberada? In: Revista Brasileira de Estudos Pedagógicos, Brasília, v. 87, n. 216, p. 178187, mai./ago. 2006. 
VAlle, I. R.; MIZUKI, G. E. P.; CASTRO, I. M. F. Democratizar, descentralizar, municipalizar: a expansão do ensino fundamental catarinense. Cadernos de Pesquisa. São Paulo, n. 121, jan./abr. 2004. 



\section{Saberes docentes na formação continuada de professores das séries iniciais do ensino fundamental: um estudo com grandezas e medidas}

Suzeli Mauro

\section{O PERCURSO DO OBJETO DA PESQUISA E A FUNDAMENTAÇÃO TEÓRICA}

A preocupação com os saberes dos professores vem ocupando um lugar central nas pesquisas sobre o processo de ensino e aprendizagem nas últimas décadas, em especial a partir do final da de 1980, constituindo-se em um campo de investigação vasto e rico. Dentre aqueles que pesquisam sobre os saberes docentes destacamos Shulman (1986); Guarnieri (1997); Gauthier e outros (1998); Pimenta (1999); Borges (2001); Tardif (2002), que a partir de abordagens diferentes, têm contribuído em várias direções como: na ênfase dada aos saberes experienciais ou práticos dos professores; no fortalecimento da idéia de que existe um saber que se encontra na base do ensino e da profissão, saber este que é construído pelos professores a partir da suas experiências profissionais e, também, pré-profissionais em um longo processo de socialização; e, ainda, no olhar lançado sobre os problemas relativos à profissionalização e à formação dos docentes, particularmente, quanto ao trato com o conhecimento e a relevância conferida aos saberes profissionais. 
Pimenta (1999), ao repensar a formação inicial e contínua, a partir da análise das práticas pedagógicas, destaca a importância da mobilização dos saberes da experiência para a construção da identidade profissional do professor, tendo em vista a sua prática com alunos de licenciatura. Neste sentido, são identificados pela autora três tipos de saberes da docência: o saber da experiência, ou seja, aqueles saberes adquiridos pelo sujeito nas experiências vividas na sua trajetória estudantil, os quais são cristalizados e constroem a base de elementos que irão nortear sua prática, bem como, o que é produzido na prática num processo de reflexão e troca com os colegas; o saber do conhecimento, que envolve a revisão da função da escola na transmissão dos conhecimentos e as suas especialidades num contexto contemporâneo; e o saber pedagógico, que compreende o conhecimento aliado ao saber da experiência e dos conteúdos específicos e que será construído a partir das necessidades pedagógicas reais. Além disso, Pimenta enfatiza que deve ser superada a fragmentação entre os diferentes saberes, considerando a prática social como objetivo central.

A idéia de que a profissão vai sendo construída à medida que o professor articula o conhecimento teórico-acadêmico, a cultura escolar e a reflexão sobre a prática docente, segundo Guarnieri (1997, p. 2), busca "a partir do pensamento e desenvolvimento profissional dos professores 'uma epistemologia da prática' que explique como se configura o processo de aprender a ensinar, de tornar-se professor”. O autor traz tal afirmação baseado em uma pesquisa realizada sobre a atuação de professores iniciantes, ao revisar pesquisas que abordam a competência para ensinar.

Dessa forma, de acordo com Guarnieri (1997), a fim de superar o modelo da racionalidade técnica, as pesquisas e os cursos de formação de professores devem redirecionar as relações entre a teoria e a prática, de modo a centrar as análises na prática docente e na identificação dos conhecimentos que são desenvolvidos pelo professor ao atuar no âmbito da cultura escolar e das condições mais adversas do seu trabalho. Além disso, buscar especificar e investigar as articulações necessárias desses conhecimentos do professor tanto com a prática, quanto com os conhecimentos teóricos acadêmicos da formação básica. Cabe ressaltar que essas articulações possibilitam o desenvolvimento da capacidade reflexiva, que favorece o compromisso com o ensino de qualidade e a competência para atuar. 
Um terceiro eixo é introduzido no processo de formação dos professores de matemática por Shulman (1986) que, tradicionalmente, se dá a partir de dois tipos de domínios, o específico e o pedagógico. Trata-se do "domínio do conteúdo no ensino" que compreende: o conhecimento sobre a matéria a ser ensinada, que se refere ao modo como o conhecimento do conteúdo da matéria está organizado na mente do professor; o conhecimento didático da matéria, que diz respeito ao modo de representar e formular a matéria, de modo a torná-la compreensível aos alunos; e conhecimento curricular da matéria, que é o conhecimento dos materiais curriculares alternativos para uma dada matéria.

O domínio do conteúdo no ensino, na perspectiva de Shulman (1986) configura-se no eixo principal da formação dos saberes da docência, uma vez que relaciona de modo intencional o saber matemático aos saberes didático-pedagógico, levando em conta o sentido formativo que está subjacente à prática escolar ao ensinar e aprender esses conteúdos.

Assim, segundo o autor para ser professor de matemática não basta ter um domínio conceitual e procedimental da matemática produzida historicamente, é necessário, sobretudo, conhecer seus fundamentos epistemológicos, sua evolução histórica, a sua relação com a realidade, seus usos sociais e as diferentes linguagens com as quais se pode representar ou expressar um conceito matemático.

Com as contribuições dos pesquisadores mencionados anteriormente, é possível identificar três saberes docentes que são essenciais no processo da formação inicial de professores, são eles: os conhecimentos epistemológicos, didáticos e específicos. Diante disso, a presente investigação aborda a formação em matemática de professores que atuam nas séries iniciais do ensino fundamental, a partir da seguinte questão: Quais saberes docentes são mobilizados na organização da ação pedagógica para o estudo de área e perímetro nas séries iniciais do ensino fundamental?

Assim, o objetivo da pesquisa foi viabilizar uma relação dialética entre a teoria e a prática no estudo de área e perímetro, por meio da organização e aplicação de uma seqüência didática com estes conteúdos, a partir de um ambiente de análise e reflexão sobre a ação pedagógica, proporcionado em um grupo de estudos, a fim de possibilitar a construção dos diferentes saberes docentes. 


\section{O CONTEXTO DA PESQUISA E OS PROCEDIMENTOS METODOLÓGICOS}

A investigação, um estudo de caso, teve origem em um grupo de estudos composto por duas formadoras, que trabalham com a disciplina Didática da Matemática no nível superior e dez professoras, que atuam nos anos iniciais da Educação Básica, em instituições particulares de ensino. Segundo Lüdke (1986, p. 18) o estudo de caso visa à descoberta e permite ao pesquisador recorrer "a uma variedade de dados, coletados em diferentes momentos, em situações variáveis e com uma variedade de tipos de informantes".

O objeto da pesquisa foram as inquietações de uma das professoras do grupo de estudos (professora investigadora), quanto ao trabalho com área e perímetro, que desencadeou na elaboração e execução de uma seqüência de atividades na $4^{a}$ série do $2^{\circ}$ ciclo do ensino fundamental, com um grupo de vinte e seis alunos, em uma instituição particular de ensino, situada no interior da Bahia.

Para tanto, a investigação pautou-se em levantamento de produções bibliográficas disponíveis em livros, revistas, internet, Cd-Room sobre os conteúdos área e perímetro; na elaboração de uma seqüência de atividades; na aplicação da seqüência em sala de aula e na análise de registros das aulas.

O desenvolvimento do trabalho com as grandezas geométricas junto às crianças das séries iniciais do ensino fundamental constituiu-se em um grande desafio para a professora investigadora, pois de acordo com seus relatos, até então, ela não sentira despertada a curiosidade ou a necessidade de trabalhar com esse bloco de conteúdo, durante a sua vivência em sala de aula. Uma explicação para isso seria o desconhecimento da importância de trabalhar tais conteúdos ou a falta de propriedade acerca de o quê, porque e como proporcionar aprendizagem numa construção tão abstrata do pensamento.

No grupo de estudos as questões da professora investigadora centravamse nos aspectos pontuados por Shulman (1986) no que se refere ao domínio do conteúdo no ensino e por Pimenta (1999), que destaca a importância da mobilização dos saberes da experiência para a construção da identidade profissional do professor, o que é retratado nas suas falas: "Como ensinar o que não foi construído na minha própria aprendizagem?" "Como descentrar um olhar perceptível para uma construção lógico-matemática?” “Como 'desconstruir' esta resistência em pensar diferente?”. 
Diante disso, foi tomada uma decisão no grupo de estudos: cada participante deveria incumbir-se de levantar questões que os inquietavam no desenvolvimento de sua ação pedagógica, sendo aberto nos encontros um espaço para estudo e discussão de cada questão. E então, a professora, sujeito deste estudo de caso, deu início à sua investigação que gerou a necessidade no grupo de um levantamento bibliográfico de produções, envolvendo área e perímetro para as discussões e posterior elaboração da seqüência de atividades.

ANÁlISE DOS RESULTADOS: OS ESTUDOS, A VIVÊNCIA EM SALA DE AULA E A CONSTRUÇÃO DE SABERES DOCENTES

A partir das reuniões do grupo de estudos, no que se refere ao estudo de caso de área e perímetro detectou-se a escassez de publicações que abordam teoricamente o ensino-aprendizagem destes conteúdos. No entanto, as poucas referências encontradas foram importante objeto de reflexões para o grupo, destacando-se dentre elas Pires (2000), Pavanello (2004), Brito e Bellemain (2004).

De acordo com os autores referidos, no estudo de área e perímetro é necessário considerar três pólos: o geométrico - que compreende as figuras geométricas e seu contorno; o numérico - que se refere às medidas das grandezas área e perímetro, composto por números reais não-negativos e da grandeza relacionado às idéias de área e perímetro, constituindo-se nas propriedades das figuras geométricas e do seu contorno. E também, recomendase uma exploração de situações de comparação, produção e medidas na resolução de situações-problema, envolvendo muitas vezes as estimativas.

A partir de tal referencial a professora investigadora realizou uma busca em diversos livros didáticos, a fim de analisar situações pedagógicas que favorecessem a construção dos conceitos de área e perímetro, considerando os três pólos acima mencionados.

No entanto, houve uma insatisfação do grupo e da professora, em especial, quanto às propostas encontradas em livros didáticos, pois se depararam com uma ênfase muito grande nos aspectos numéricos, o que não era o objetivo maior; necessitava-se de situações que proporcionassem uma reflexão sobre os aspectos geométricos, da grandeza e numéricos, a fim de favorecer a aprendizagem das crianças quanto à área e perímetro. 
É possível destacar nas discussões do grupo o empenho e envolvimento da professora investigadora, a fim de desenvolver um trabalho considerando as potencialidades e necessidades dos seus alunos. Segue uma de suas falas:

O desejo em fazer diferente foi aumentando, e por meio das parceiras no grupo foi também ganhando sentido. As nossas discussões favoreceram que eu me transformasse em aprendiz.

A cada encontro, a professora ao invés de apontar simplesmente o que desejava, reunia diferentes situações didáticas que faziam os professores do grupo identificar em quais momentos tinha-se uma abordagem no campo geométrico, das grandezas ou numérico. À medida que os encontros aconteciam, as discussões tornaram-se cada vez mais promissoras e um suporte teórico foi sendo construído. Segundo depoimento da professora, vinculado ao referencial estudado, a experiência de compartilhar uma prática de intervenções a fez aprender o que pretendia ensinar. Vale ressaltar a sua fala em uma das discussões no grupo de estudos:

O professor precisa conhecer e ter propriedade do que deseja ensinar, ou é assim, ou se finge ensinar. Ele precisa colocar-se na posição do aluno (de aprendiz).

Durante o processo a professora perguntava-se: "Será que estou preparada para extrapolar, ou pelo menos, assegurar o nível de aprendizagem desejada?”.

Apesar da resposta negativa durante um período, ela começava a sentirse pautada nas possíveis intervenções que deveria fazer, pois o seu processo de construção começava a sustentar o que pretendia construir com as crianças. Sabia que neste tipo de ação pedagógica muitas surpresas poderiam surgir, afirmações e questionamentos das crianças que desestruturariam a sua ação inicial, mas era certo de que tinha condições de aproveitar, ao máximo, construções pessoais no decorrer da seqüência que levariam a um crescimento coletivo.

$\mathrm{Na}$ elaboração da proposta efetiva de trabalho, a fim de organizar seus encaminhamentos, a professora procurou levantar o conhecimento prévio dos alunos e possíveis dificuldades quanto à área e perímetro. Em seu levantamento a professora constatou que os alunos: confundem área $\mathrm{e}$ perímetro, assim como contorno e superfície; não diferenciam grandezas e medidas de grandeza; geralmente, calculam medidas utilizando fórmulas, sem saber o que exatamente calculam; costumam pensar que somente os 
polígonos que tem nome e fórmulas possuem área e perímetro; confundem contorno e perímetro.

Assim, para a fundamentação do ensino-aprendizagem a professora firmou seu olhar para algumas intencionalidades, como: introduzir o estudo de perímetro e área, distinguindo e articulando a partir do quadro geométrico e do quadro das grandezas; vincular situações-problema que viabilizam e dão sentido à construção do conceito de área que são: situações de comparação, de medida e de produção; proporcionar situações significativas para as crianças, que podem envolver o uso de materiais concretos e situações didáticas que dispensam o uso deste tipo de materiais, como exemplo, a fala num momento de discussão coletiva ou de articulações de idéias em duplas; diferenciar e articular o quadro geométrico e das grandezas, ou seja, comparar sem medir.

Desse modo, a seqüência de atividades elaborada e discutida nos encontros do grupo de estudos, que segue, efetivou uma relação dialética entre teoria e prática, visto que cada atividade ao ser construída mobilizou os estudos e reflexões sobre o ensino-aprendizagem de área e perímetro, realizados anteriormente nas sessões:

\section{$1^{a}$ Situação-problema:}

Mariana costuma fazer caminhadas matinais. Próximo a casa dela existem quatro lagos e a cada dia da semana ela realiza três voltas ao redor de um deles. Observe a seguir estes lagos:

\section{Figura 1}

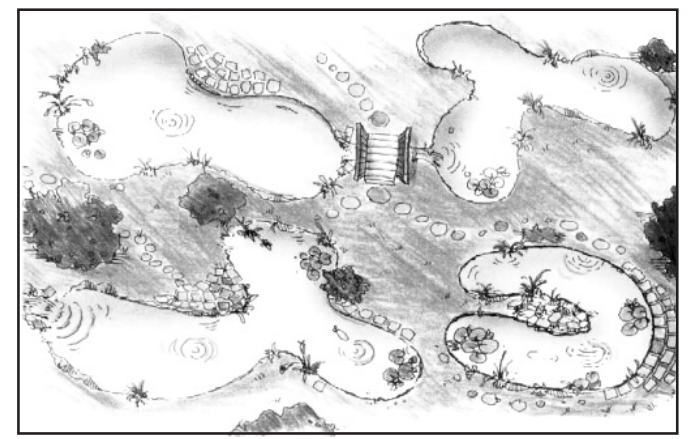

Fonte:SMOOTHEY, 1997, p.8. 
Em qual dos lagos ela percorre uma distância maior? E a maior distância? Qual(is) o(s) procedimentos(s) que você deve utilizar para afirmar suas respostas com maior segurança?

\section{$2^{a}$ Situação-Problema:}

Marina adora criar figuras em malha. As últimas que ela produziu ficaram bem originais. Mas há um problema: ela precisa definir qual(is) dela(s) ocupa $(\mathrm{m})$ o maior espaço.

Observe cada uma delas:

\section{Figura 2}

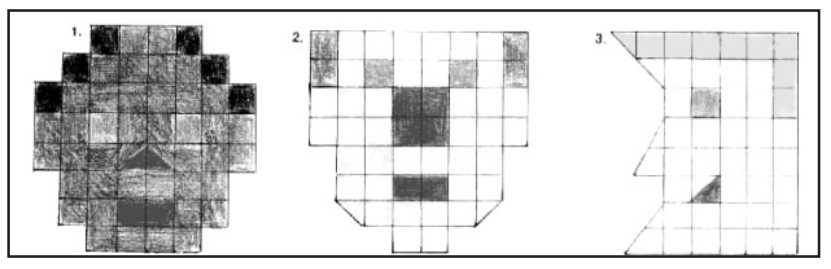

Fonte:SMOOTHEY, 1997,p.43.

Tente ajudá-la a descobrir e explique como você pensou para chegar às conclusões.

\section{$3^{\text {a }}$ Situação-Problema:}

1. Desafio Legal:

Qual dos dois terrenos ocupa maior espaço? O resultado está de acordo com a sua estimativa apenas com a observação das formas? (Figura 3)

2. É possível calcularmos a área da figura mais escura? Como? (Figura 4) 
Figura 3

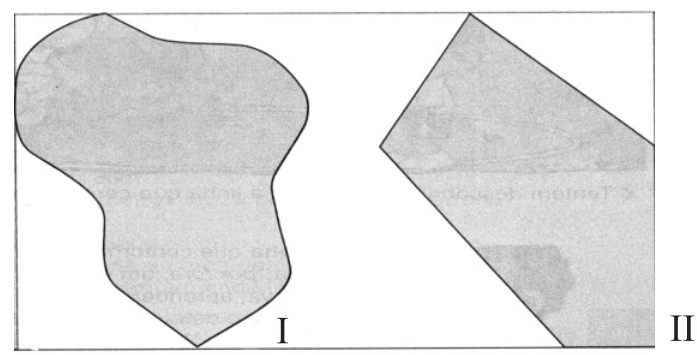

Fonte: BIGODE, 2000, p.259.
Figura 4

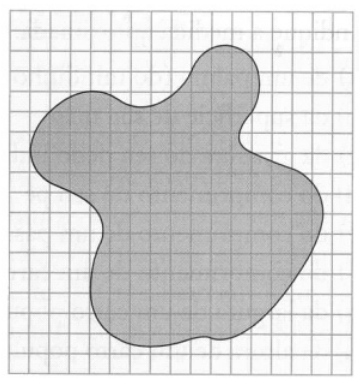

\section{$4^{\text {a }}$ Situação-Problema:}

1. Observe a figura abaixo feita com palitos de fósforo.

\section{Figura 5}

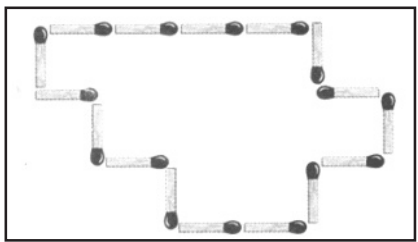

Fonte: BIGODE, 2000, p.258.

Considerando como unidade de medida "O palito de fósforo", responda:

a) Qual o perímetro da figura? E a área?

b) Movimente só 2 palitos para que a figura ganhe mais $1 \mathrm{pq}$ (palito por quadrado) de área.

c) Movimente o menor número possível de palitos para que a figura fique com área de 15 pq. (Figura 5). 


\section{$5^{\text {a }}$ Situação-Problema:}

"Está acontecendo uma grande reforma em minha casa. Resolvi mudar o piso da cozinha e do pátio. Veja como é cada um desses espaços.”

\section{Figura 6}

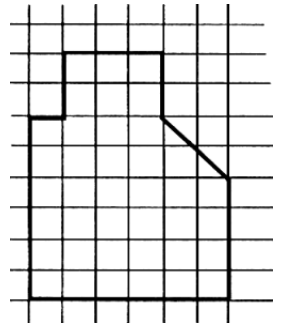

Cozinha

Na cozinha decidi colocar

uma cerâmica deste tipo:

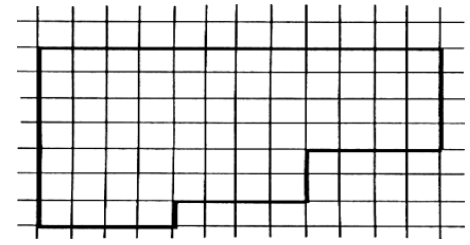

Pátio

Para o pátio, preferi utilizar este tipo de cerâmica:

Fonte:PONCE, 1999, p.78.

Agora, um desafio:

Eu calculei que para a cozinha vão ser necessárias 40 cerâmicas e para o pátio 17. Portanto, podemos afirmar que a cozinha tem mais superfície (para colocar a cerâmica) que o pátio? Justifique a sua resposta.

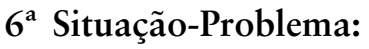

I Momento:

Um terreno tem $90 \mathrm{~m}$ de perímetro.

a) Desenhe como pode ser esse terreno e indique as medidas de cada lado.

II Momento:

Observe as quatro figuras a seguir: 


\section{Figura 7}

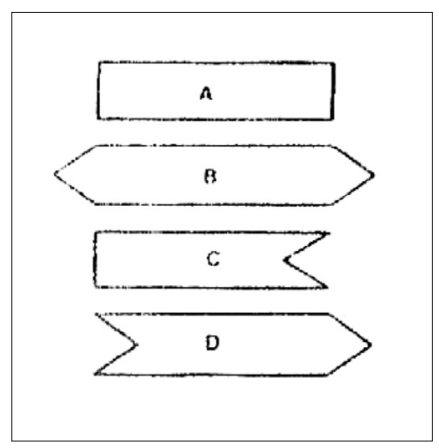

Fonte: FACCO, 2003.

a) Identifique estas figuras da que tem a menor área à que tem a maior área. Justifique sua resposta.

b) Entre elas há figuras que têm a mesma área? Justifique sua resposta.

c) Identifique estas figuras da que tem o menor perímetro à que tem maior perímetro. Justifique sua resposta.

d) Entre elas há figuras que têm mesmo perímetro? Justifique sua resposta.

$7^{\text {a }}$ Situação-Problema:

1. Leia toda a atividade abaixo e responda:

Marília, Luísa e João Pedro, são irmãos, eles estão construindo uma casa de praia. Este mês os pedreiros darão início ao assentamento do piso, para isso cada um dos irmãos ficou responsável por comprar uma parte da cerâmica. João comprou a cerâmica da área de circulação da lateral esquerda da casa, Luísa de um dos quartos da casa e Marília a da área de serviço.

Os pisos comprados serão arrumados da seguinte maneira:

$4 \mathrm{~m} \times 5 \mathrm{~m}$ $10 \mathrm{~m}$ X $2 \mathrm{~m}$

$1 \mathrm{~m}$ X 20m

a) A qual dos espaços em negrito corresponde cada uma dessas arrumações? Justifique a sua resposta.

b) A área e o perímetro dos três espaços são iguais? Justifique a sua resposta. 
c) Considerando que os demais espaços de casa são: 2 quartos, 1 cozinha, 1 sala de jantar, 1 sala de estar, 1 banheiro, 1 corredor e o restante da área de circulação ao redor da casa. Organize na malha quadriculada abaixo a planta da casa de praia. Cada quadrinho representa $1 \mathrm{~m}^{2}$.

Ah, toda a malha deve ser utilizada e a área de circulação ao redor de toda casa deve constar nesta malha.

\section{Figura 8}

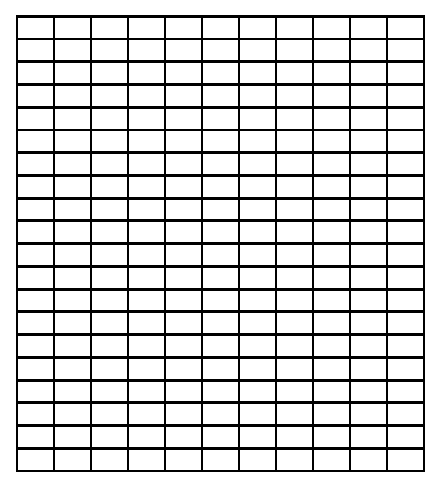

\section{$8^{a}$ Situação-Problema:}

As plantas a seguir foram construídas por algumas crianças da $4^{a}$ série. Vamos analisá-las?

Veja quais espaços a malha quadriculada deveria conter.
a) 3 quartos
d) 1 sala de estar
g) 1 área de serviço
b) 1 cozinha
e) 1 banheiro
h) área de circulação ao redor
c) 1 sala de jantar
f) 1 corredor

Obs.: Trata-se de uma casa de praia. 


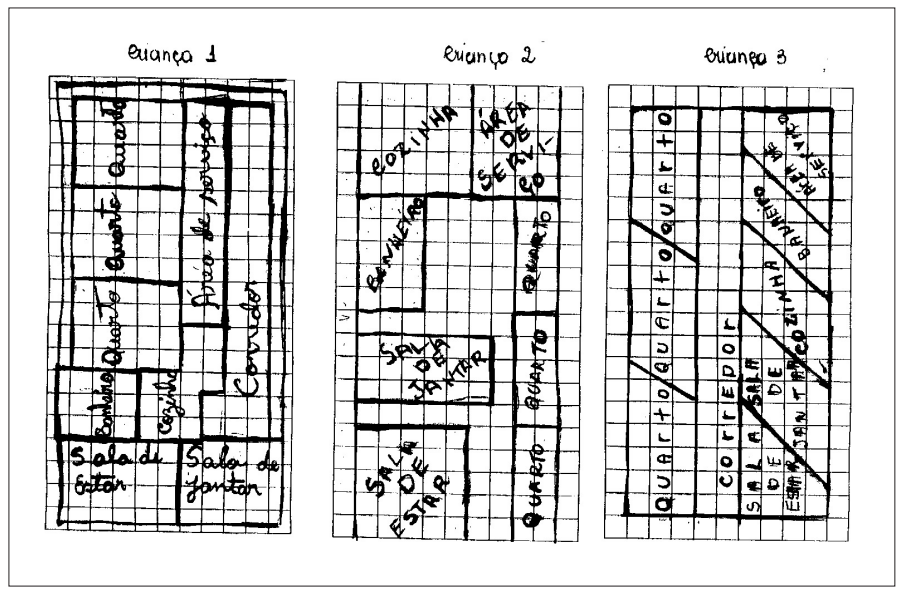

$\mathrm{Na} 3^{a}$ situação proposta existem dois momentos. No primeiro momento, as crianças foram postas em uma situação de comparação de grandezas da mesma natureza (superfície) apenas com a observação das figuras geométricas sem nenhum suporte de divisão das mesmas para nortear o resultado. Esta atividade é semelhante a da $1^{a}$ situação-problema, porém diferenciam-se quanto à grandeza a ser comparada.

No segundo momento nenhuma criança discordou de que seria possível calcular uma área aproximada; as situações de discussões anteriores deram suporte para esta conclusão única.

A articulação de conhecimentos da grandeza área aos conhecimentos das propriedades da figura e de seu contorno fez-se necessária. A partir desta articulação, uma criança chamou as pequenas partes (que não eram quadrados) de pontas irregulares, considerando-as metade de um quadrado, portanto possível de calcular. Uma outra afirmou que era possível calcular, porque todo o espaço de um terreno tem que ser considerado, independente de ser plano (regular nas medidas) ou curvo.

Muitas afirmaram que as partes incompletas do quadrado não correspondiam à metade, por isso dificultaria um valor mais aproximado possível.

As crianças chegaram à conclusão que dependendo de quem iria calcular, poderia encontrar valores diferentes. 
Uma criança em especial, levantou um questionamento que se transformou situação de pesquisa:

Um arquiteto possui instrumentos modernos para calcular esse tipo de terreno?

A professora investigadora perguntou o motivo de sua dúvida e ela respondeu.

Ora pró, já pensou no tempo que ele pode perder sem esses instrumentos? E ainda correr o risco de pedir uma quantidade de materiais desnecessários para a construção. Coitado, eu acho que se não tiver, ele perde muita clientela.

Neste momento a construção da aprendizagem ganha o que tanto se prega nas nossas diretrizes educacionais: uma função social.

A $7^{\text {a }}$ Situação-Problema foi a que a professora investigadora considerou de maior riqueza em toda seqüência, pois para ela:

A atividade envolve os três pólos: geométrico, grandezas e numérico articulados em situações de comparação, produção e medidas. Além disso, trata-se de reflexões que viabilizam um pensar sobre o social. As crianças precisaram reportar-se ao seu cotidiano por uma necessidade implícita na tarefa. As crianças têm as medidas, pautada nisto, produzem o espaço e com a visualização deste, tentam adequar ao objetivo de ocupação deste espaço (objetos grandes ou pequenos / maior ou menor circulação de pessoas).

A professora destaca ainda outra reflexão: Áreas iguais nem sempre determinam perímetros iguais, uma intencionalidade, visto que, na $6^{a}$ Situação-problema houve uma pequena confusão neste aspecto.

Segundo a professora investigadora houve uma indecisão no grupo em relação a definir $4 \mathrm{~m} \times 5 \mathrm{~m}$ e $10 \mathrm{~m} \times 2 \mathrm{~m}$, para o quarto ou área de serviço e $10 \mathrm{~m} \times 2 \mathrm{~m}$ e $1 \mathrm{~m} \times 20 \mathrm{~m}$ para circulação da lateral esquerda.

Veja como pensaram algumas crianças:

$4 \mathrm{~m} \times 5 \mathrm{~m}$ é para o quarto, pois todos os quartos sempre são quase quadrados.

$4 \mathrm{~m}$ x 5m é para área de serviço, porque precisa colocar só a parte de higiene que é pequeno.

$10 \mathrm{~m} \times 2 \mathrm{~m}$ - área de serviço, pois não precisa ser um lugar comprido e sim largo.

$1 \mathrm{~m} \times 20 \mathrm{~m}$ - área de circulação. Neste espaço sempre vejo largura pequena e bem cumprida. Acho que é porque passa pouca pessoa, não é um espaço que acumula pessoas. 
$10 \mathrm{~m} \times 2 \mathrm{~m}$ - este é ideal para área de circulação, pois o corredor tem uma largura menor e o comprimento maior porque acompanha o comprimento da casa.

Já na $8^{a}$ Situação-problema a professora investigadora decidiu junto ao grupo de estudos, pautada na produção da situação anterior, coletar três plantas-baixa para reflexão de adequação de espaços a partir do terreno disposto e dos objetos que deverão compor as pequenas repartições (sala, cozinha, quarto...).

As crianças foram orientadas a pensar sobre:

1. Qual das representações há uma maior adequação do espaço ao objetivo desejado (casa de praia)? Por quê?

2. Existe algum elemento que poderia ser colocado nas plantas e com sua ausência dificulta a compreensão sobre as mesmas?

Os pensamentos das crianças foram bem incisivos em alguns aspectos, apresentados a partir de uma reelaboração das falas das mesmas:

1. As pequenas repartições podem dispor os objetos, dando maior comodidade quando são quadrados ou retangulares.

2. Não há corredor do lado da parede, geralmente ficam no centro porque eles existem para dar acesso aos outros cômodos.

3. Não é comum cozinha ficar no meio da casa e sala de jantar no início.

4. A área de serviço deve ficar próxima à cozinha porque facilita o trabalho da dona de casa e também é mais higiênico.

5. Na planta-baixa, precisa ser sinalizado, aonde tem portas e janelas aonde é frente e fundo.

Cabe ressaltar que as falas dos alunos foram objeto de análise do grupo de estudos e retratam as construções das crianças.

Um outro aspecto a ser enfatizado é a relevância da situação de comparação das produções pelos alunos, que proporcionou momentos enriquecedores na construção do conhecimento. 


\section{CONSIDERAÇÕES FINAIS}

A partir da pesquisa realizada pode-se perceber que a construção de saberes docentes, no que se refere ao "domínio do conteúdo no ensino", efetivou-se por meio da ação reflexiva da prática desenvolvida e dos processos interativos nos encontros do grupo de estudos.

Diante disso, ao considerar o processo de apropriação dos saberes sobre área e perímetro é possível ressaltar a importância da articulação da professora entre as construções dos saberes específicos associado a um olhar reflexivo sobre os saberes epistemológicos, que possibilita desenvolver uma visão sobre como se processa a construção cognitiva pelo aluno, em relação a tais conteúdos, para daí acionar saberes didáticos que viabilizem a elaboração de atividades.

Destaca-se nesse estudo, a construção pela professora investigadora quanto à importância no tratamento didático de área e perímetro em considerar que as atividades devem contemplar os pólos geométrico e das grandezas, e não apenas o numérico, visto que identificou-se nos estudos que a dificuldade de compreensão pelos alunos dos conceitos de área e perímetro estão relacionadas com a ênfase dada nas atividades apresentadas nos livros didáticos para o pólo numérico.

Assim, a seqüência "Medindo, comparando... produzindo", caracterizou-se como uma proposta desafiadora, à medida que, possibilita um trabalho com área e perímetro. Explorou-se o comparar sem medir; as possibilidades de respostas a partir da tarefa cognitiva do aluno sem necessariamente partir da exatidão do campo numérico, o que não significou um abandono no que se refere às medidas das grandezas quando constituídas por números, apenas deixou de ser um fim, para tornar-se mais um meio na construção das idéias destas grandezas.

A partir das discussões e reflexões ocorridas ao longo do estudo e do desenvolvimento da seqüência, validou-se a importância de situações de comparação e produção na compreensão do que é contorno/perímetro, superfície/área e área/perímetro. Por trás destas ações didáticas existe um nível de reflexão significativo, porque faz com que a criança elabore diferentes estratégias, não restritas àquelas que envolvem o medir para definir com certeza as suposições solicitadas em torno de área e perímetro. 
Além disso, possibilita intervenções que levem ao uso de materiais concretos na construção das idéias, não sendo este o único meio importante, dependendo da situação-problema proposta.

A professora investigadora destaca a relevância social do trabalho com medidas e grandezas:

\begin{abstract}
Por muitas vezes, em meio às nossas descobertas, percebia as crianças analisando o piso da sala; falando que quando fosse receber uma mobília nova para o seu quarto, iria participar da escolha, procurando proporcionar a si mesmas mais comodidade; questionando-se e aos outros como funciona o trabalho de um arquiteto; lendo revistas que tratam do assunto; enfim, tantas outras situações que me faziam sentir feliz e com desejo de continuar mediando esse processo de construção.
\end{abstract}

Vale ressaltar que, é na ação que o profissional se depara com a necessidade de reconstruir o seu conhecimento matemático para atribuir sentido as ações de seus alunos.

Além disso, como contribuição desse estudo tem-se a importância da confrontação das práticas consagradas pela experiência estudantil dos professores com as novas perspectivas para a ação pedagógica e da dialética entre teoria e prática, promovidas pelo processo interativo no grupo de estudo dos professores que atuam nas séries iniciais.

Assim, instala-se um ciclo de construção e reconstrução dos saberes docentes em que o professor coloca-se em busca de um novo saber, que deve ser questionado e refletido por meio das experiências vivenciadas no grupo em que atua. Nesse momento, o professor constitui-se como profissional reflexivo, crítico e investigativo da sua prática pedagógica.

\title{
REFERÊNCIAS
}

BIGODE, A. J. L. Matemática hoje é feita assim. São Paulo: FTD, 2000.

BRASIL. Ministério da Educação. Fundescola. Módulo TP4 do Programa de Gestão de Aprendizagem Escolar Gestar I: Grandezas e Medidas. Wilsa Marie Ramos (supervisão geral). Brasília: FUNDESCOLA/MEC, 2004.

BARBOSA, P. R.; BRITO, A. F. de. Algumas reflexões sobre duas pesquisas relacionadas à grandeza comprimento. ENCONTRO NACIONAL DE EDUCAÇÃO MATEMÁTICA, 8., 2004, Recife. Anais... Recife: Universidade Federal de Pernambuco, 2004. p. 1-15. 
BRITO, A. F. de; BELLEMAIN, P. M. B. Influência do uso de materiais manipulativos na construção da grandeza comprimento. ENCONTRO NACIONAL DE EDUCAÇÃO MATEMÁTICA, 8., 2004, Recife. Anais... Recife: Universidade Federal de Pernambuco, 2004. p. 1-20.

FACCO, S. R. Conceito de área: uma proposta de ensino-aprendizagem. 2003. 185f. Dissertação (Mestrado em Educação Matemática) - Pontifícia Universidade Católica de São Paulo, São Paulo. Anexo I.

GAUTHIER, C. et al. Por uma teoria da pedagogia: pesquisas contemporâneas sobre o saber docente. Unijuí: Ed. Unijuí, 1998.

GUARNIERI, M. R. O início na carreira docente: pistas para o estudo do trabalho do professor. REUNIÃO ANUAL DA ASSOCIAÇÃO NACIONAL DE PÓS-GRADUAÇÃO E PESQUISA EM EDUCAÇÃO, 20., 1997. Caxambu. Anais... Caxambu: ANPED, 1997.

LÜDKE, M. Pesquisa e educação: abordagens qualitativas. São Paulo: EPU, 1986.

PAVANELLO, R. M. A Geometria nas séries iniciais do Ensino Fundamental: contribuições da pesquisa para o trabalho escolar. In: Matemática nas séries iniciais do Ensino Fundamental: a pesquisa e a sala de aula. São Paulo: Biblioteca do Educador Matemático, (Coleção SBEM, v. 2) 2004.

PIMENTA, S. G. Saberes pedagógicos e atividades docentes. In: PIMENTA, S. G.(Org.). Formação de professores: identidade e saberes da docência. 2. ed. São Paulo: Cortez, 1999.

PIRES, C. M. C.; CURI, E.; CAMPOS, T. M. M. Como as crianças constroem noções de perímetro e área. In: - Espaço e forma: a construção de noções geométricas pelas crianças das quatro séries iniciais do Ensino Fundamental. São Paulo: PROEM, 2000.

PONCE, H. Enseñar y aprender matemática: proposta par el segundo ciclo. Buenos Aires: Ediciones Novedades Educativas, 1999.

SHULMAN, L. S. Those who understand: Knowledge Growth. Teaching. Educational Researcher, v. 15, n. 2, p. 4-14, 1986.

SMOOTHEY, M. Atividades e jogos com área e volumes. São Paulo: Editora Scipione, 1997. (Coleção Investigação Matemática)

TARDIF. M. Saberes docentes e formação profissional. Petrópolis: Vozes, 2002. 328p. 


\section{Educação musical: um estudo a partir de experiências pedagógicas na Escola de Música da Universidade Federal da Bahia}

Leila Miralva Martins Dias

Antes de iniciarmos propriamente a abordagem do tema, convém traçar um breve quadro conjuntural da trajetória do ensino de música no Brasil, para facilitar o acesso da questão a um público mais amplo. Apesar do reconhecimento que sempre se deu à música no campo das artes, somente nos últimos 30 anos, vem-se destacando a sua contribuição para a formação e o desenvolvimento humano das pessoas em geral. Levantemos então, resumidamente, uma visão panorâmica da situação.

A música foi praticamente extinta do ensino médio, desde o início dos anos 60 do século XX, quando a Lei de Diretrizes e Bases da Educação (LDB) alterou profundamente o currículo do ensino médio, permitindo a sua flexibilização. Ao longo desses 45 anos, a disciplina música tem aparecido apenas como um diferencial em certas instituições de ensino, ou como “ornamento" em ocasiões especiais. Excluído o ensino da música do ambiente escolar, ele foi confinado aos ambientes acadêmicos onde se afirma virtuoso e profissionalizante.

Para as crianças, os adolescentes e jovens, no ensino pré-universitário, ao longo desse tempo, quando muito, o quê havia eram aulas de música já direcionadas para o instrumento com a perspectiva do virtuosismo. Os 
professores davam aulas particulares em suas casas ou em conservatórios e os alunos levavam para casa as lições para praticarem como estudos de técnica e algumas peças de compositores eruditos, geralmente, da cultura européia (DIAS, 1992).

Assim, depois dos anos de 1960, até os nossos dias, tornando-se a música eletiva como disciplina, a relação do sistema educacional brasileiro com o ensino da música retrocedeu vertiginosamente à República Velha, quando a instrução pública mal se esboçava. Neste aspecto, a situação tornou-se mais dramática do que na República Nova, inaugurada nos anos de 1930, quando, apesar das restrições de ordem política, tornou-se obrigatório o ensino de música nas escolas públicas.

Dos anos de 1930 até os anos 1960, no entanto, o fazer musical no sistema oficial de ensino era chamado de Canto Orfeônico, que, através da predominância dos hinos patrióticos, assumia claramente objetivos de formação cívica e moral, e a iniciação musical, realizada dominantemente na rede privada de ensino, em pequenos grupos com canções folclóricas (FUKS, 2007).

Coincidentemente, os anos que se sucederam à Lei de Diretrizes e Bases da Educação dos anos de 1960, foram marcados pelo desenvolvimento dos meios de comunicação de massa, sobretudo a televisão e o cinema, uma vez que o rádio teve o seu desenvolvimento já desde os anos de 1930. E foi justamente, através desses meios de massa, que se processou, dominantemente, de forma assistemática e ao sabor dos interesses comerciais, o ensino da música no Brasil.

Entretanto, as transformações sociais ocorridas no País, entre os anos de 1960 e 1980, sobretudo marcadas por severas restrições à participação dos diferentes setores sociais, levaram os setores interessados no desenvolvimento cultural à busca de formas de expressão que, a um mesmo tempo, fossem o protesto contra a situação vigente, e significasse o surgimento uma nova forma de viver e expressar o mundo. Embora todas as artes tivessem sido mobilizadas, a música, pelo seu potencial de difusão, alcançou papel mais destacado. Todo o Brasil acompanhou os Festivais da Canção Popular. A nova geração de músicos passou a expressar os anseios de liberdade tanto política, como existencial (HOLANDA; GONÇALVES, 1986).

Entramos, definitivamente, em um novo tempo. Desde então, as artes, de um modo geral, passaram a ser valorizadas não apenas como bem 
simbólico de consumo, mas, sobretudo, como algo a ser buscado no processo de educação. Passou-se a reconhecer a contribuição da educação artística na formação, não apenas das crianças, mas dos jovens e adultos de todas as idades. Nesse contexto, a música assume um destaque preponderante e assume novos rumos (BRASIL, 1997).

A educação musical, independentemente do reconhecimento oficial pelo poder público, transpôs os muros da academia e passou a ser uma aspiração social. Então, de modo diverso de períodos históricos anteriores como estudados por Souza (2007) e Fuks (2007), é a própria sociedade, dessa vez, que se mobiliza ao encontro da educação musical, não mais como mecanismo de controle social e político como fizeram os regimes autoritários do passado, mas como uma necessidade para o desenvolvimento humano.

Inegavelmente, essa nova tendência tem como marcos importantes o fortalecimento das pesquisas em educação musical nos cursos de pósgraduação desde os anos de 1980 e a criação da Associação Brasileira de Educação Musical (Abem), em 1991 (OLIVEIRA; CAJAZEIRA, 2007). Graças a esses esforços dos educadores musicais, nos dias de hoje, apesar do ensino da música ainda permanecer periférico ao sistema de ensino oficial, os pesquisadores de Educação Musical vêm afirmando-o, a passos largos, como área específica de conhecimento e de investigação científica (SOUZA, 2007).

As pesquisas têm revelado que a tradicional "aula de música", com teorias, solfejos e abordagens descontextualizadas, perde cada vez mais espaço. A nova preocupação dos educadores musicais, no entanto, não é somente re-significar essa "aula de música", mas também expandir seu campo de atuação abraçando as manifestações culturais, legitimando os diversos outros espaços em que ela está presente, a exemplo das práticas musicais religiosas, dos contextos fora da escola e das experiências musicais diversas no cotidiano das pessoas (SOUZA, 2001). Além disso, dentro da sociedade mais ampla, vem-se fortalecendo a movimentação política pela inclusão do ensino da música no sistema educacional brasileiro, contandose inclusive, a essa altura, com projeto de lei em tramitação no Congresso Nacional.

As pesquisas desenvolvidas sobre o ensino da música no Brasil, sobretudo a partir dos programas de pós-graduação, têm colocado alguns elementos para a reflexão tanto dos educadores, como de pais, de líderes 
comunitários e de autoridades educacionais sobre a importância da educação musical para a formação do sujeito. Em conseqüência, essas reflexões têm exigido uma tomada de posição de todos em relação ao que vem sendo denominado de uma educação musical e não mais um mero ensino da música.

A realidade contemporânea, os novos objetivos da educação musical, os diversos espaços, as novas demandas da área e as expectativas trazidas pelos estudantes de música, portanto, nos fazem refletir acerca de modos de pensar diferenciados para atuar nessa nova realidade. Nessa nova situação, o educador se encontra diante não só de uma vastidão de espaços, onde a educação musical acontece, mas também diante de um universo de alunos mais conhecedores do repertório musical disponível na mídia e mais consciente de suas próprias expectativas de aprendizagem.

Os alunos, que procuram a aprendizagem musical na atualidade, são portadores de objetivos bastante variados. Além do desejo de aprender um instrumento, procuram a prática musical como um meio de interação social, de entretenimento, da busca pelo lazer e muitos outros. Ou seja, a música não é mais somente um veículo de formação artístico-cultural, mas também um instrumento de formação integral do indivíduo. Ela é também fator de afirmação de identidades e um campo que abriga a diversidade cultural brasileira.

Portanto, todas essas transformações no contexto da educação musical e, sobretudo considerando as subjetividades do aluno de música da atualidade, produziram mudanças que se impõem ao novo educador musical para que ele possa contemplar essa nova realidade com outros modos de atuação, diferentes dos habituais, legitimando as experiências trazidas tanto pelo aluno, como pelo professor.

\section{PROJETO CORAL DA ESCOLA DE MÚSICA DA UFBA: FUNDAMENTOS TEÓRICO-METODOLÓGICOS}

Tendo em conta as contribuições que têm emergido das pesquisas no campo da educação musical e a visão dessa realidade contemporânea, o Projeto Pedagógico da Escola de Música da Universidade Federal da Bahia (UFBA), que serve de norte tanto para os seus cursos de graduação e pósgraduação, como para os seus diversos projetos de extensão considera que: 
Diante desta realidade, a escola não é mais considerada lugar exclusivo de aprendizagem na sociedade do conhecimento, na qual são múltiplas as oportunidades de ensinar e aprender. Da mesma forma, a área de educação musical expandiu-se em várias dimensões: faixas etárias, espaços de atuação, modalidades e metodologias. Se até há pouco tempo entendia-se o ensino de música principalmente voltado para as crianças, hoje são contempladas todas as idades: desde os recém-nascidos até a terceira idade. Surgiram novos espaços e outros ganharam reconhecimento: além do ensino específico de música (cursos de extensão universitária, conservatórios, cursos técnicos e de graduação) e as escolas regulares públicas e particulares, entraram em cena as ONGs, os projetos sociais, o ensino a distância, o ensino de música para portadores de necessidades especiais, as manifestações da cultura popular, entre outros. As modalidades, inicialmente voltadas para a musicalização infantil, passam a compreender qualquer tipo de conjunto instrumental, vocal ou misto, aulas de cunho mais teórico e a formação de professores. Às metodologias ativistas se juntaram outras abordagens (UNIVERSIDADE..., 2006, p. 6).

Com o objetivo de assegurar maior clareza sobre o que se espera dos educadores musicais diante dos desafios dos novos tempos, o presente ensaio apresenta experiências pedagógico-musicais, desenvolvidas através de projetos de extensão, com adultos, jovens e adolescentes, através do coro livre e performático, onde, normalmente, o compromisso dos alunos com o coral não é necessariamente prioritário em suas vidas.

A formação de coros performáticos, que se caracterizam por aliar a dança e/ou o teatro ao canto, tem sido cada vez mais freqüente, em diferentes pontos do Brasil, a exemplo do grupo da professora Ana Maria dos Santos, de Belém e dos corais regidos pelo Maestro Cícero Alves, em Salvador, Simone Raslam, em Porto Alegre e outros.

O trabalho com o coro performático, como visto acima, assume também um caráter interdisciplinar. Assumindo-se a idéia de que o educador deve promover um ensino que aborde, além das mais recentes inovações tecnológicas, elementos que contemplem a simplicidade, a natureza e o encontro do homem consigo mesmo. Essa mesma idéia é presente na proposta oficial dos Parâmetros Curriculares Nacionais (PCNs) para Arte.

A interdisciplinaridade, como nos adverte Luck (1999):

corresponde a uma nova consciência da realidade, a um novo modo de pensar, que resulta num ato de troca, de reciprocidade e integração entre áreas de conhecimento, visando tanto a produção de novos conhecimentos como a resolução de problemas, de modo global e abrangente (LUCK, 1999, p. 62). 
Também, com essa tendência, vêm-se informalizando a postura de palco dos coros, vinda dos moldes tradicionais, mantida durante muitos anos nos corais eruditos do Brasil e do mundo. Estas práticas performáticas têm como objetivos, entre outros, aumentar o nível de expressão e motivação dos coristas através da integração entre as linguagens artísticas, estimular o desenvolvimento dos educandos em outras dimensões humanas, além de provocar um maior interesse e envolvimento da platéia (DIAS; SANTA ROSA, 2007).

Esse trabalho fundamenta-se nas contribuições teórico-metodológicas de educadores musicais como Willems, Orff, Dalcroze e Swanwick, Oliveira, Souza e outros que convergem em torno da idéia de que o educador musical tem como uma de suas principais funções, possibilitar aos alunos o (re)descobrimento de valores em diferentes dimensões, interior e exteriormente (LANDIS; CARDER, 1972).

A criação ou mesmo a montagem de espetáculos musicais, portanto, apresenta-se, nesse contexto, como uma ferramenta educacional enérgica favorecendo, nos alunos, tanto o seu desenvolvimento musical, quanto artístico e cultural. Além disso, favorece o crescimento intelectual, o desenvolvimento psicomotor e emocional, proporcionando ao educando o contato com as dimensões do sentimento, do prazer e da alegria.

Esse trabalho, ao par com as bases da nova educação musical, fundamenta-se também nas idéias de educadores e teóricos contemporâneos do campo da educação em geral, como Paulo Freire, Edgar Morin e Jean Piaget. A cada espetáculo que se cria e se realiza, pode-se observar como a educação musical se torna efetiva a partir da transformação das aulas num encontro dos saberes do professor e dos alunos.

As contribuições desses autores, portanto, levam à consideração de que o desejo e o saber trazidos pelo aluno para o contexto educacional são tão importantes quanto o desejo e o saber do professor. Tem-se observado, ao longo desses anos, como a instauração desse processo dialógico torna possível perceber e alargar as possibilidades de práticas educacionais, que contribuem, não apenas para o crescimento dos alunos como seres pensantes, sociais, individuais, artísticos, musicais e, sobretudo, humanos, mas servem também, de modo extraordinário, ao aperfeiçoamento e a realização dos educadores.

A educação contemporânea ou do futuro, como diz Morin, por sua vez, valoriza o saber do educando e o considera elemento necessário para a 
construção do conhecimento. $\mathrm{O}$ aluno deve ser a parte mais importante no processo de ensino-aprendizagem tendo participação ativa no desenvolvimento dos conteúdos e nas atividades com as quais ele lida. $\mathrm{O}$ conhecimento teórico passa a ser algo adquirido com a vivência prática, podendo fazer parte de um conjunto de experiências do aluno diretamente ligadas à sua realidade e das quais ele pode se apropriar, tornando-se dono do seu próprio saber (MORIN, 2000).

Nessa mesma trilha, autores da educação musical já destacam a importância de se valorizar o cotidiano do aluno no processo de ensino e aprendizagem, abrindo espaço para uma educação participativa com resultados efetivos (TOURINHO, 1995; SOUZA, 2000; ARÓSTEGUI, 2000; 2007).

Nesse sentido, considera-se que o trabalho de educação musical, no projeto coral, procura valorizar o espaço para a expressão do aluno e da sua individualidade, o incentivo à imaginação e à criatividade, a atenção à emoção, à afetividade, e à sociabilidade, a busca pela autonomia do conhecimento adquirido, o alcance da teoria a partir da prática, o diálogo professor/aluno em prol do conhecimento do mundo do aluno e da contribuição do professor, o conhecimento global do conteúdo trabalhado e a integração das individualidades para a construção de um todo musical artístico, educacional, sociocultural e, sobretudo, humano (DIAS; QUADROS, 2007).

\section{O DESENVOLVIMENTO DAS ATIVIDADES}

As atividades de educação musical com os jovens e adultos, no coral performático, a cada ano, começam com a elaboração de um projeto de um espetáculo musical (WHITE, 1999). Tem-se como princípio não selecionar previamente os prováveis participantes, considerando apenas, como exigências básicas, que sejam membros do Projeto Coral. Frequentemente há alunos e professores dos cursos de extensão, graduação e pós-graduação da Escola de Música e de outros cursos da UFBA. O importante é que estejam interessados e comprometidos com o trabalho. Não é exigido nenhum tipo de experiência anterior e nem habilidades específicas. 
Assim, as limitações apresentadas por alguns dos integrantes não provocam prejuízos ao resultado final do trabalho, pois elas costumam ser trabalhadas durante o período de um ano letivo. Para a realização desses trabalhos, além dos coralistas, conta-se eventualmente, com a participação de professores de teatro e dança, para ajudar a dar sentido ao roteiro e a ampliar a espontaneidade e presença de palco dos educandos.

Uma vez discutido e acertado com o grupo a realização do espetáculo a ser apresentado ao final de cada ano, são escolhidos os responsáveis para cada setor de produção necessária à realização do projeto tais como figurinista e tesoureiro e outros. Alguns desses papéis podem ser assumidos por uma ou duas pessoas, ou mesmo pelo coletivo dos educandos que passam a desempenhá-los através de processos dialógicos sob a coordenção do professor ou professora que exerce também a direção geral.

Nesse sentido, os participantes tornam-se também organizadores. Os próprios coristas assumem as responsabilidades por todos os passos necessários para a realização do espetáculo. Espera-se que esse envolvimento com o desempenho de tarefas voltadas para o projeto comum, proporcionem não só o acolhimento do saber do aluno trazido do seu dia dia, mas também novas descobertas e a ampliação dos seus horizontes pessoais de vida, tanto como indivíduos, como seres sociais (SANTA ROSA; DIAS, 2007).

No primeiro dia de aula, $\mathrm{o}(\mathrm{a})$ professor(a)-regente propõe a formação de uma grande roda com alunos. Inicialmente ele(a) se apresenta e pede para que cada um dos participantes se apresente. Declarando, inclusive, os motivos que os levaram a participar de um processo de educação musical. Ainda no primeiro dia, são realizados trabalhos de aquecimento e relaxamento corporais. Além disso, vão sendo introduzidas várias outras dinâmicas como jogos, brincadeiras rítmicas, improvisações vocais e corporais com a intenção de proporcionar a descontração e um estado de espírito aberto e criativo. Daí em diante, esses momentos são repetidos a cada dia, antes do início das atividades musicais e artísticas (SANTA ROSA, 2006).

Uma vez decidido o tema, outras dinâmicas vão sendo realizadas para descobrir maneiras de expor o tema do espetáculo em um coro performático com a intenção clara de chegar à montagem de um musical com texto, contemplando arranjos vocais, dança e teatro. Paralelamente a isso, já se começa a levantar um repertório de canções referentes ao tema. Depois de 
muitas sugestões e experimentações, vão sendo selecionadas as músicas que são encaminhadas aos alunos de graduação para serem elaborados os arranjos. Comumente, os criadores dos arranjos se encarregam de ensaiar com o coro.

Quando as vozes estão ensaiadas, é a vez de todos os coristas se voltarem para criar coreografias compatíveis com a proposta da música e do tema escolhido. Para essa parte convida-se um coreógrafo para auxiliar na criação e no aperfeiçoamento das coreografias. Para o desenvolvimento do tema, geralmente convida-se também um graduando ou professor de teatro que, em comum acordo com os membros do grupo, coordena a criação das falas e das cenas, propostas no tema escolhido. Essa aproximação com outros profissionais das áreas de artes, caracteriza também, um trabalho interdisciplinar artístico.

Ao longo do ano, por diversas vezes, avalia-se o processo, os resultados e vão sendo traçados os passos seguintes. Geralmente, faz-se uma grande roda com todos os alunos sentados no chão, onde eles se colocam para relatar um pouco de como estão vendo o desenvolver do trabalho até àquele momento. $\mathrm{A}(\mathrm{o})$ professor(a) pede para que cada um deles aponte $\mathrm{o}$ que está vendo como positivo ou negativo, o que está faltando e pede novas sugestões para serem acrescentadas ao trabalho.

Com esse diálogo, normalmente surgem, como aspectos positivos detectados por eles, comentários ligados à evolução do tema e aos resultados obtidos ao longo do caminho percorrido. De negativo, críticas a uma música ou outra que poderia ser trocada, um arranjo que está sendo difícil de apreender, uma coreografia que está confusa e outros aspectos relacionados à dinâmica do grupo, tais como atraso de alguns participantes para os ensaios e outros. E como sugestões eles sempre propõem cenas novas que são experimentadas imediatamente e, quando aceitas pela maioria, são acrescidas ao trabalho.

No segundo semestre, em geral, é escolhido o teatro em que devem ser realizadas as apresentações públicas do musical. Aí, o trabalho costuma adquirir um perfil mais profissional, pois já se utiliza figurino apropriado, iluminação especial, sonorização para coristas e instrumentistas, cenário ligado ao tema, providências para divulgação e todos os elementos que surgem em virtude do que é próprio do espetáculo musical apresentado em um teatro. 
Como os corais recebem muitos convites para apresentações em diversos espaços, quando há possibilidade, a primeira apresentação do musical se faz em eventos, quase como um ensaio geral para a apresentação no teatro. Portanto, geralmente, durante os meses de novembro e dezembro o trabalho pode ser apresentado em parte ou por inteiro, de acordo com o teor dos convites. No entanto, o coral tem além do musical, um repertório extramusical incluindo canções de natal para atender a convites diversos, inclusive por ocasião das festas natalinas.

A partir de 2006, em relação aos outros musicais realizados nos anos anteriores ${ }^{1}$,de forma intencional, aprofundou-se ainda mais a participação dos alunos na criação do espetáculo, designando por inteiro a escolha do tema, do repertório, das coreografias e das cenas. Nesse caso a interferência da professora-regente foi apenas para conduzir, conectar as idéias surgidas, avaliar com eles e dirigir os ensaios. Portanto, o trabalho criativo foi construído inteiramente com a participação de cada um dos coristas.

\section{CONSIDERAÇÕES FINAIS}

Entre as contribuições trazidas, por essas experiências, ao crescimento dos indivíduos, pode-se destacar em primeiro lugar os aspectos relacionados ao desenvolvimento musical, onde se percebe um evidente crescimento da sensibilidade rítmica, melódica e harmônica, através da execução vocal, instrumental e da vivência corporal; a familiarização com as diversas épocas e estilos de cada um dos temas trabalhados.

Em segundo lugar, os aspectos do desenvolvimento artístico, revelando que os alunos desenvolvem a expressividade de um modo geral com o exercício de corpo, de execução vocal, de interpretação teatral e da experiência artística e estética, do convívio com o palco e diversos elementos que envolvem a apresentação em um teatro da cidade.

Em terceiro lugar, destacam-se os aspectos sociais por onde os alunos apresentam uma sensível melhora da convivência em grupo, da confiança mútua e da solidariedade; os aspectos psicológicos por onde, na grande

\footnotetext{
O projeto Coral realizou dez musicais São eles: "Volta ao Mundo" em 1996; "Fotos Musicais" em 1997;"Viver Bahia" em 1998; "Rimas da Bahia" em 1999, que foi uma remontagem aprimorada do Viver Bahia;"Sucessos de 10 em 10" em 2000; "Sucessos de 10 em 10" em 2001, repetição atualizada; "Brasil em Canto" em 2002 e

"Lacinho Cor-de-Rosa" em 2003,"Lamento Sertanejo" em 2005, “Aprisionamento" em 2006.
} 
maioria das pessoas, ocorre a superação dos bloqueios e da timidez, o desenvolvimento da autoconfiança e a construção e elevação da auto-estima; os aspectos cognitivos, onde são desenvolvidos, além de conhecimentos gerais, as habilidades de memorização, imaginação e de criação.

Nesse contexto descrito do trabalho do Projeto Coral, todos os coristas assumem papéis de responsabilidades indispensávies para o sucesso do projeto coletivo. Esse envolvimento dos participantes, também como organizadores, permite a ampliação dos seus horizontes, tanto artísticos e culturais, como diante da vida em sociedade. Esse progresso se evidencia de modo mais claro quando se observa o desempenho de cada um, ou cada grupo em suas tarefas específicas, como descritas em seguida.

O pesquisador realiza estudos e pesquisas desenvolvendo a habilidade de extrair o conteúdo essencial que posteriormente será exprimido nas linguagens dramática e musical. $\mathrm{O}$ roteirista estuda minuciosamente o conteúdo pesquisado e aprende a unir estas informações ao objetivo da direção geral e transportá-las para o texto de uma forma criativa e apropriada para o gênero. Os figurinistas, além de estarem atentos aos rumos tomados pela montagem da peça, realizam pesquisas de estilos e costumes de acordo com o contexto histórico e geográfico da trama. $\mathrm{O}$ tesoureiro tem em sua mente, melhor do que qualquer outro participante, a noção da quantidade de componentes envolvidos na montagem de um espetáculo, além de estar sempre atualizado nos preços de mercado dos serviços.

O arranjador e diretor musical aprende a conhecer as limitações e capacidades vocais, corporais e cênicas do grupo de forma a contemplar estes elementos de maneira adequada nos arranjos, nas coreografias e nas cenas organizando-os de forma harmoniosa. A direção teatral desenvolve possibilidades de criação com pessoas leigas nesta área e com diferentes tipos de egos no propósito de fazer com que o espetáculo expresse fluidez e uniformidade nas passagens de texto para música e vice-versa.

O Coreógrafo aprende a criar seqüências que estejam de acordo com a capacidade do grupo e com o contexto da peça. Os músicos fazem pesquisas e treinos constantes de estilos e repertórios diversos, ampliando a compreensão da história da música e da execução instrumental. O diretor geral vive um processo de busca pela conciliação e pela sensibilidade de acolher o todo e a todos sem perder de vista o resultado final. 
Diante dos resultados obtidos, reforça-se o reconhecimento da importância do diálogo no processo da educação, sobretudo, musical. Além do mais, pode-se perceber a vastidão de possibilidades para o desenvolvimento das práticas de educação musical, trazendo crescimento para alunos e educadores como seres pensantes, sociais, individuais, artísticos, musicais e, sobretudo, humanos com a prática de uma democracia significativa.

Por fim, cumpre destacar que todo esse trabalho constitui-se numa ocasião singular para os licenciandos em música, alunos de instrumento, composiçao e regência, alunos de teatro e de dança, que vivenciam intensamente todo o processo, complementando a sua formação de educadores musicais para os novos tempos e consequentemente favorecendo ao educador em geral a criação de abordagens pedagógicas voltadas para a escuta do seus aprendizes, atendendo a uma demanda contemporânea onde o saber do aluno e o saber do professor se entrelaçam buscando a contrução de sentido na aprendizagem mútua.

\section{REFERÊNCIAS}

ARÓSTEGUI, J. L. Democracia y currículo: la participación del alumnado en el aula de música. Tesis doctoral. Universidad de Granada, 2000.

Participación del alumnado en el proceso de enseñanza aprendizaje. Participación educativa. Revista del consejo escolar del estado. n. 2. 2006. Disponível em: <www.mec.es/cesces/revista_participacion_ educativa_2/revista2.htm>. Acesso: 18 mai. 2007.

BRASIL. Secretaria de Educação Fundamental. Parâmetros curriculares nacionais. Arte/Secretaria de Educação Fundamental. Brasília: MEC/SEF, 1997.

DIAS, Lelia Miralva Martins. Developments in piano pedagogy. 1992. $240 \mathrm{f}$. Thesis (Degree of Master of Philosophy in Musical Education) - Faculty of Education, University of Manchester, Manchester..

DIAS, Leila Miralva Martins; QUADROS, João Jr. Educação musical participativa: um relato de experiência sobre o processo de criação de um Musical partindo dos integrantes do Coral Juvenil. ENCONTRO ANUAL DA ASSOCIAÇÃO BRASILEIRA DE EDUCAÇÃO MUSICAL E CONGRESSO REGIONAL DA INTERNATIONAL SOCIETY FOR MUSIC EDUCATION NA AMÉRICA LATINA, 16., 2007, Campo Grande. Anais... Campo Grande: UFMS, 2007, p.1-6. 
DIAS, Leila Miralva Martins; SANTA ROSA, Amélia Martins Dias. Companhia Artística Viver Bahia: identificando os elementos educacionais na prática de Musicais. CONGRESSO DA ASSOCIAÇÃO NACIONAL DE PESQUISA E PÓS-GRADUAÇÃO EM MÚSICA,17., 2007, São Paulo. Anais... São Paulo: ANPPOM, 2007. p. 1- 6.

FREIRE, Paulo. Pedagogia da autonomia: saberes necessários à prática educativa. 30. ed. Rio de Janeiro: Paz e Terra, 2004.

FUKS, Rosa. A Educação musical da Era Vargas: seus precursores. In: OLIVEIRA, Alda; CAJAZEIRAS, Regina (Org.). Educação Musical no Brasil. Salvador: P\&A, 2007. p. 18-23.

HOLANDA, H. B. de; GONÇALVES, M. A. Cultura e Participação nos anos 60. São Paulo: Editora Brasiliense, 1986.

LANDIS, Beth; CARDER, Polly. The eclectic curriculum in american music education: the contributions of Dalcroze, Kodaly, and Orff. USA: Music Educators National Conference, 1972.

LUCK, Heloísa. Pedagogia interdisciplinar: fundamentos metodológicos. Petrópolis: Editora Vozes, 1999.

MORIN, Edgar. Os sete saberes necessários à educação do futuro. Tradução de Catarina Eleonora F. da Silva e Jeanne Sawaya. 2. ed. São Paulo: Cortez; Brasília: UNESCO, 2000.

OLIVEIRA, Alda. Múltiplos Espaços e Novas Demandas Profissionais na Educação Musical: competências necessárias para desenvolver transações musicais significativas. ENCONTRO ANUAL DA ASSOCIAÇÃO BRASILEIRA DE EDUCAÇÃO MUSICAL, 10., 2001, Uberlândia, Anais..., Uberlândia: ABEM, 2001. p. 19-40.

SANTA ROSA, Amélia Martins Dias. A construção do musical como prática artística interdisciplinar na educação musical. 2006.183 f. Dissertação (Mestrado em Música) - Escola de Música, Universidade Federal da Bahia, Salvador.

SOUZA, Jusamara. Múltiplos espaços e novas demandas profissionais: reconfigurando o campo da Educação Musical. Revista da ABEM, Uberlândia, n. 10, p. 85-92, out. 2001.

. (Org.). Música, cotidiano e educação. Porto Alegre: Programa de Pós-Graduação em Música do Instituto de Artes da UFRGS, 2000.

Pensar a educação musical como ciência: a participação da ABEM na construção da área. Revista da ABEM, Porto Alegre, n. 16, p. 25-30, mar. 2007.

SWANWICK, Keith. Ensinando música musicalmente. Tradução de Alda Oliveira e Cristina Tourinho. São Paulo: Moderna, 2003. 
TOURINHO, Ana C. A motivação e o desempenho escolar na aula de violão em grupo: influência do repertório de interesse do aluno. 1995. 314 f. Tese (Doutorado em Música) - Escola de Música, Universidade Federal da Bahia, Salvador, 1995.

WHITE, Matthew. Staging a musical. London: A \& C Black, 1999.

WILLEMS, Edgard. As bases psicológicas da educação musical. Bienne: Pró-music, 1970.

UNIVERSIDADE FEDERAL DA BAHIA. Projeto pedagógico: curso de licenciatura em música: 2006. Salvador, 2006. 


\title{
Sobre os autores
}

\author{
Ana Célia da SiLva \\ Doutora em Educação pela Universidade Federal da Bahia (UFBA), \\ Professora Adjunta do Departamento de Educação e do Programa Educação \\ e Contemporaneidade do Campus I da Universidade do Estado da Bahia \\ (UNEB) e Membro Titular do Conselho Estadual de Cultura para compor \\ a Câmara de Política Sócio Cultural.E-mail: pacss@terra.com.br.
}

ANTÔNIO Dias NASCIMENTO

PhD pela Universidade de Liverpool, Inglaterra. Professor do Departamento de Ciências Humanas e do Programa de Pós Graduação em Educação e Contemporaneidade, da Universidade do Estado da Bahia (UNEB), Campus I. Membro da Linha Educação, Gestão e Desenvolvimento Local e Sustentável. E-mail: andiasst@hotmail.com.

Cristina Maria d’Ávila

Pós-Doutora pela Universidade de Montréal, Canadá. Professora adjunta do Departamento de Educação e do Programa de Pós-graduação em Educação e Contemporaneidade - Universidade do Estado da Bahia. Professora adjunta da Faculdade de Educação da Universidade Federal da Bahia. E-mail: cmdt@ufba.br.

Elizeu Clementino de Souza

Doutor em Educação pela FACED/UFBA. Professor da Faculdade de Educação da Bahia (FEBA), e do Programa de Pós-Graduação em Educação e Contemporaneidade da Universidade do Estado da Bahia (UNEB). Coordenador do GT de Educação Fundamental da ANPEd (2006/2007). E-mail: esclementino@uol.com.br. 
IONE Ribeiro VALLE

Doutora em Ciências da Educação - Université René Descartes - Paris V Sorbonne. Professora do Departamento de Estudos Especializados em Educação (EED) - Centro de Ciências da Educação - Universidade Federal de Santa Catarina (UFSC). E-mail: ionevalle@ced ufsc.br

\section{Jaci Maria Ferraz Menezes}

Doutora em Ciências da Educação pela Universidade Católica de Córdoba, Argentina. Professora de História da Educação e Política da Universidade do Estado da Bahia. Bolsista de produtividade em Pesquisa da FAPESB, pesquisa sobre História da Educação e sobre Educação e Desigualdades. E-mail: jacimnz@uol.com.br.

Juvino Alves dos Santos Filho

Doutor em Música pela Universidade Federal da Bahia. Ensina Educação, Música e Sociedade no Programa de Pós-graduação em Educação e Contemporaneidade da UNEB. Bolsista de Pós-Doutorado 1 da FAPESB, pesquisa sobre Bandas, Filarmônicas e Mestres de Banda da Bahia, no campo dos estudos sobre cultura musical brasileira. E-mail: juvinoalves@gmail.com.

\section{Leila Miralva Martins Dias}

Mestra em Educação Musical pela Universidade de Manchester, Inglaterra. Doutoranda em Educação Musical, pelo Programa de PósGraduação em Música, da Universidade Federal do Rio Grande do Sul. Professora da Escola de Música da Universidade Federal da Bahia. E-mail: leidias12@hotmail.com.

\section{LeILA SCHEIBE}

Doutora em Educação: História, Política, Sociedade pela Pontifícia Universidade Católica de São Paulo (PUC/SP). Professora Titular e Emérita da Universidade Federal de Santa Catarina (UFSC) e vinculada ao Mestrado em Educação da Universidade do Oeste de Santa Catarina (UNOESC) Joaçaba/SC. E-mail: lscheibe@uol.com.br. 


\section{LuCiENE MARIA DA SiLVA}

Professora doutora e pesquisadora do Programa de Pós-Graduação em Educação e Contemporaneidade da Universidade do Estado da Bahia (UNEB), componente da Linha. E-mail: luciene@portfolium.com.br.

\section{Maria de Lourdes S. Ornellas}

Prof $^{a} \operatorname{Dr}^{a}$ em Psicologia da Educação. Prof ${ }^{a}$ Permanente do Programa de Pós-Graduação em Educação e Contemporaneidade. Pesquisadora nas áreas de afetividade e representação social na Linha 2 - Educação, tecnologias intelectuais, currículo e formação do educador. Psicanalista. E-mail: ornellas1@terra.com.br.

\section{Maria Olívia de Matos Oliveira}

Doutora em Calidad y Procesos de Innovación Educativa - Universidad Autonoma de Barcelona. Professora Adjunta da Universidade do Estado da Bahia (UNEB), vinculada ao Programa de Pós-Graduação em Educação e Contemporaneidade (PPGEduC) e Professora da graduação da UCSal. E-mail: oliveiramattos@gmail.com.

\section{Rosana Mara Chaves Rodrigues}

Socióloga e mestre em Educação e Contemporaneidade, professora da Universidade do Estado da Bahia, Departamento de Ciências Humanas e Tecnologias - Campus XVI/Irecê-Ba. Pesquisadora do Núcleo de Educação do Campo do CampusXVI/UNEB - Irecê-Ba, Coordenadora do PRONERA (Programa Nacional de Educação na Reforma Agrária) na PROEX/UNEB. E-mail: rmararodrigues@uol.com.br.

\section{SANDRA ReGINA SOARES}

Psicóloga, Mestre em Educação pela Universidade Federal da Bahia e Doutora em Educação pela Université de Sherbrooke - Québec-Canadá. Professora do Departamento de Educação Campus I e do Programa de Pós-graduação em Educação e Contemporaneidade (UNEB) - Campus I. Linha 2. Área de pesquisa formação de professor - pedagogia universitária. E-mail: sandra.soares@usherbrooke.ca. 


\section{SuZELI MAURo}

Professora Mestre e Doutora em Educação Matemática pela Universidade Estadual Paulista Julio de Mesquita Filho (UNESP), com pesquisas realizadas na Universidade de Bielefeld, Alemanha.E-mail: suzimauro@yahoo.com.br.

\section{VÂNIA FinHOLdT ÂNGELo LeITE}

Mestre Ensino, Filosofia e História das Ciências pelo Programa de Pósgraduação da Universidade Federal da Bahia (UFBA) e aluna especial do Programa de Pós-Graduação em Educação (doutorado) da Universidade do Estado do Rio de Janeiro (UERJ). E-mail: vfleite@uol.com.br.

\section{Wilson Roberto de Mattos}

Doutor em História Social pela PUC/SP. Professor Adjunto de História da Universidade do Estado da Bahia. Coordenador do Programa de PósGraduação em Cultura, Memória e Desenvolvimento Regional - UNEB/ Campus V. $1^{\circ}$ Vice Presidente da Associação Brasileira de Pesquisadores Negros (ABPN).E-mail: wmattos@uneb.bre mattosfamily@uol.com.br.

\section{Yara Dulce Bandeira de Ataíde}

Doutora em Educação pela Universidade Federal do Rio Grande do Norte (UFRN) e Professora do Programa de Pós-Graduação em Educação e Contemporaneidade (PPGEduC) da Universidade do Estado da Bahia (UNEB). E-mail: yaraataide@terra.com.br.

\section{ZeNILDE DURLI}

Mestre em Educação, Doutora em Educação pela Universidade do Estado de Santa Catarina (UFSC) e professora na Universidade do Oeste de Santa Catarina (UNOESC). E-mail: zenilde.durli@unoesc.edu.br. 

Este livro foi composto no formato $170 \times 240 \mathrm{~mm}$ utilizando a fonte Sabon LT.

Impresso em papel $75 \mathrm{~g} / \mathrm{m}^{2}$ no

Setor de Reprografia da Edufba.

Impressão de capa e acabamento da Bigraf

Tiragem 600 exemplares

Salvador, 2007. 